Szegedi Tudományegyetem

Földtudományok Doktori Iskola

\title{
VÁROSKLÍMA-ELEMZÉS TÉRBEN ÉS IDŐBEN RÉSZLETES MÉRÉSEK, VALAMINT LOKÁLIS LÉPTÉKÜ KLÍMAMODELL ALAPJÁN
}

\author{
Doktori (Ph.D.) értekezés
}

\section{Skarbit Nóra}

Témavezető:

Dr. Unger János

tanszékvezető egyetemi tanár

SZTE Természettudományi és Informatikai Kar Éghajlattani és Tájföldrajzi Tanszék 


\section{Tartalomjegyzék}

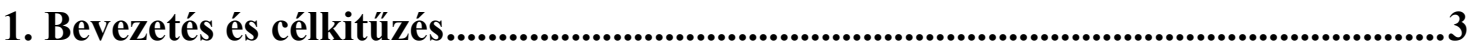

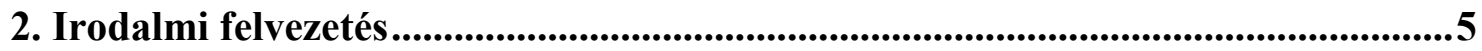

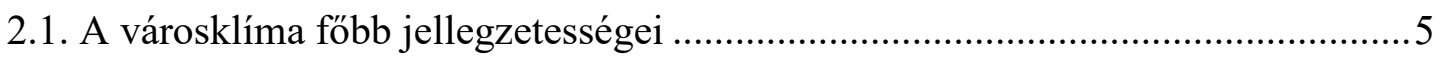

2.1.1. Városi népesség aránya, várható növekedése ............................................5

2.1.2. A városklíma kialakulása és a városi légkör szerkezete ...............................6

2.1.3. A város sugárzási mérlege és energiaegyenlege ......................................... 7

2.1.4. Hőmérséklet-módosulás a városban........................................................ 8

2.1.5. A hősziget intenzitását befolyásoló tényezők ............................................ 10

2.2. A lokális klímazóna koncepció kialakulásának folyamata ..................................11

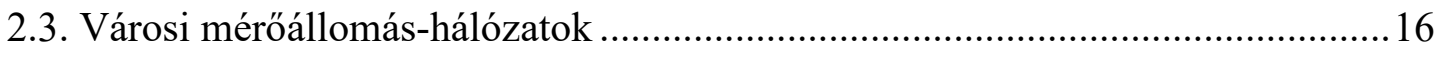

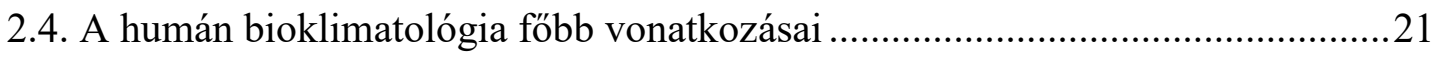

2.5. Globális és regionális éghajlati modellek .....................................................23

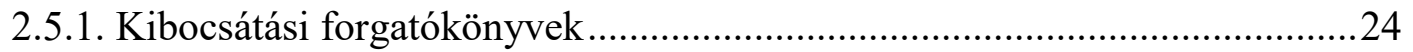

2.5.2. Klímaváltozást vizsgáló projektek ...........................................................26

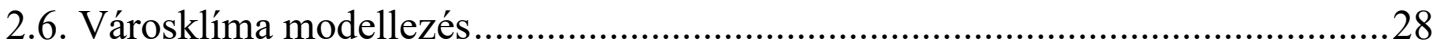

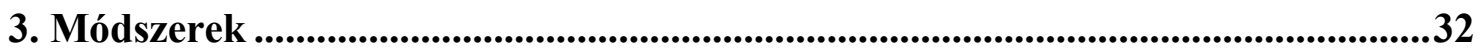

3.1. Szeged lokális klímazónáinak meghatározása és területi eloszlásuk...................32

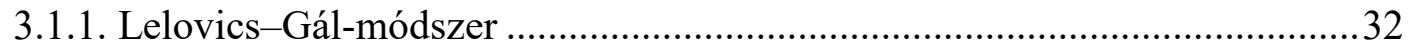

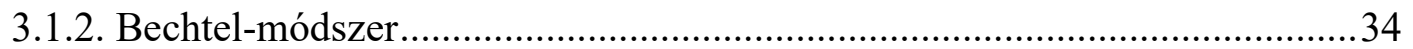

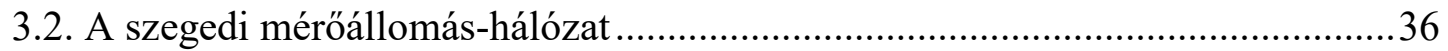

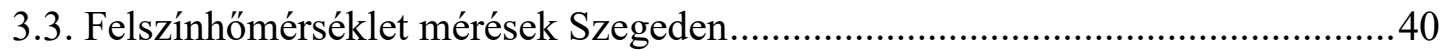

3.4. A fiziológiailag ekvivalens hőmérséklet és modellezése ..................................43

3.5. Az alkalmazott EURO-CORDEX modellszimulációk és hibakorrekciós eljárás ....44

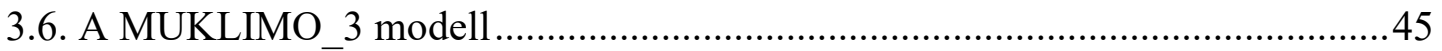

3.7. A cuboid módszer és az alkalmazott klímaindexek ..............................................48

3.8. A vizsgált időszakok és felhasznált adatok.........................................................49

3.8.1. A léghőmérséklet vizsgálata ......................................................................49

3.8.2. A felszínhőmérséklet vizsgálata................................................................50

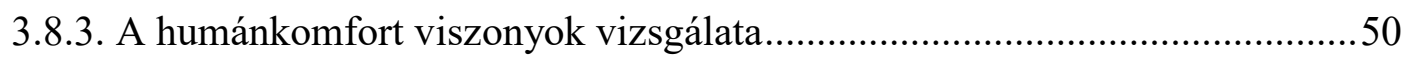

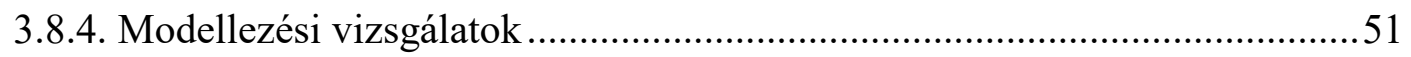

4. A lokális klímazónák léghőmérsékleti sajátosságai............................................53

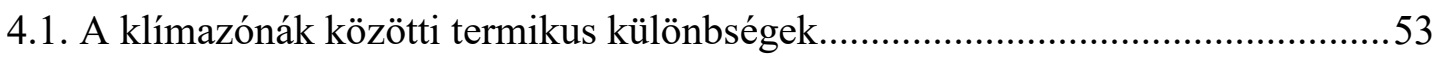

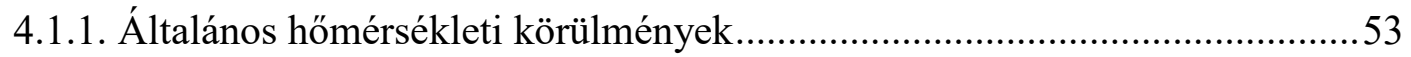

4.1.2. A hősziget intenzitásának évi, évszakos és napi jellegzetességei .................54 
4.1.3. Klímaindexek változása .57

4.2. Az egyes klímazónákon belüli termikus különbségek......................................59

5. A városi hőmérsékleti mintázat térbeli-időbeli dinamikája .62

5.1. Az évi átlagos hősziget mintázat fel- és leépülése a teljes időszakban és az ideális napokon...

5.2. A hősziget és a lokális klímazónák kapcsolata egy ideális nap éjszakáján .........65

5.3. A hőmérsékleti gradiens térbeli-időbeli dinamikája .........................................66

6. A lokális klímazónák felszínhőmérséklet-különbségei.........................................70

6.1. A teljes területre vonatkozó felszínhőmérsékletek vizsgálata ...........................70

6.2. Közvetlenül a földfelszínre vonatkozó értékek vizsgálata ................................71

7. A lokális klímazónák humánkomfort viszonyainak elemzése ..............................74

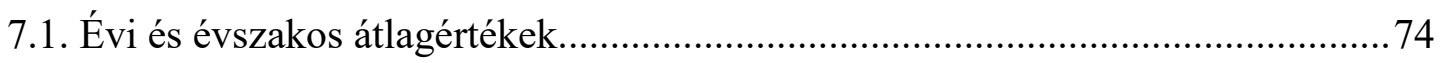

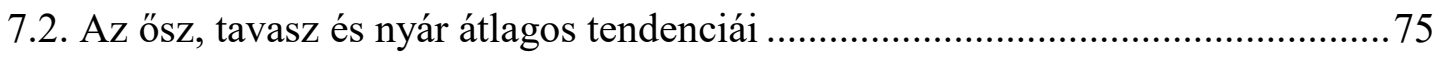

7.3. A 2015.08.12-16. közötti hőhullámos időszak vizsgálata..................................77

8. Klímaindexek módosulásának előrejelzése ...........................................................79

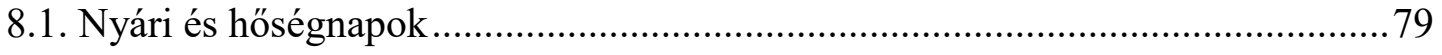

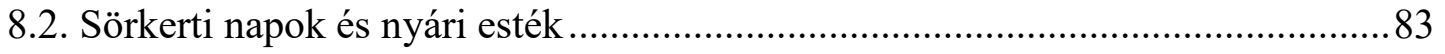

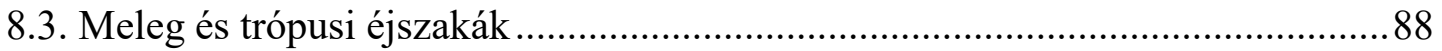

8.4. A klímaindex elörejelzés validációja ..............................................................92

9. Összegző gondolatok, kitekintés..........................................................................94

Irodalomjegyzék ....................................................................................................99

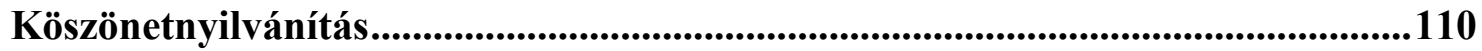

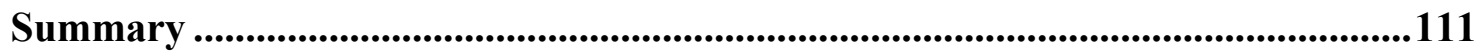




\section{Bevezetés és célkitüzés}

Napjainkban a városklimatológiai kutatások kiemelt érdeklődésre tartanak számot. Ennek ténye nem meglepö, ha figyelembe vesszük, hogy nemcsak Földünk népessége növekedett, hanem ezen belül magának a városi lakosságnak az aránya is. Az előrejelzések alapján ez a tendencia folytatódni fog és a jövőben a népesség jelentős többsége városokban fog élni. Ennek köszönhetően az ott jelenlévő helyi, sajátos klimatológiai viszonyok megismerése egyre indokoltabbá válik, mivel a városokban a beépített, mesterséges környezet és a regionális éghajlat kölcsönhatásaként egy speciális klíma alakul ki. A természeteshez képest megváltozott felszín és az emberi tevékenység következményeként ezeken a területeken módosulnak a sugárzási mérleg elemeinek, és az energiaegyenleg komponenseinek súlya és szerepe (Oke, 1987).

A vidéki és városi terület eltérő jellegének eredményeként a beépített területen egy hőtöbblet jelenik meg, amely leginkább éjszaka jellemző és ekkor éri el maximális intenzitását is. Ezt, a városklimatológiában leginkább ismert jelenséget, sajátos térbeli alakjának köszönhetően hőszigetnek nevezzük és nagyságát a városi és vidéki terület hőmérséklet-különbségével definiáljuk. Mérése történhet állomáspárral, megfelelő gyakoriságú mobil méréssel vagy kellően sürü állomáshálózattal. Mivel megadása egy-egy adott területen elhelyezett mérési pont adatának figyelembevételével történik, ez felveti a beépítés jellegéből fakadó eltérések problémáját is. Ugyanis a városon belül ez a mérőállomás lehet nagy magasságú, sürün beépített felhőkarcolók között vagy akár egy parkban is. Ez hasonlóan elmondható a vidéki területről, ami az alacsony növényzet és a sürün elhelyezkedö fás terület között változhat, de akár lehet egy repülötér is. Ennek köszönhetően a hősziget intenzitás értéke a mérés helyétől függően eltérhet, hiszen a beépítés jellege nagyban befolyásolhatja a kapott hőmérséklet-különbséget. Más oldalról megközelítve, ha nem meglévő állomások környezetét akarjuk jellemezni, hanem a telepítésnél kívánjuk megadni a város termikus jellegzetességeit visszaadó mérőpontok helyét, felmerül a városi területek osztályozásának igénye. Az elmúlt évtizedekben ezeknek a problémáknak a megoldására több osztályozást fejlesztettek ki, amelyek végső eredményének a lokális klímazónák 2012-ben megalkotott rendszerét tekinthetjük (Stewart, Oke, 2012). A zónák között egyaránt vannak beépítettséget és természetes felszínborítást jellemző típusok, amelyek elnevezése megkülönböztető felszínparamétereiken alapul. A rendszer úgy lett megalkotva, hogy a világ bármely pontján alkalmazható legyen, így a használatával kapott eredmények más települések esetében is figyelembe vehetők, illetve összehasonlíthatók.

Az osztályozás használatával megadhatók az egyes felszíntípusok sajátos klímamódosító tulajdonságai, ami segíti a városi méröállomások megfelelő elhelyezését. Gondolva itt arra, hogy mely területeken és hány állomást szükséges elhelyezni, hogy a település beépítési sajátosságait tükröző termikus mintázatot a legpontosabban kapjuk meg. A Szegeden 2014-ben telepített méröállomás-hálózat elemei úgy lettek elhelyezve, hogy közvetlen környezetük az előforduló zónákra reprezentatívak legyenek. A 24 állomásból álló hálózat térbeli felbontása nemzetközi szinten is kiemelkedőnek mondható. Adatainak felhasználásával elemezhetők a zónák, azaz az eltérő beépítés között fellépő termikus különbségek és a több állomással rendelkezőkben az értékek változékonysága. Az állomások percenként mérik a léghőmérsékletet és a relatív nedvességet, így az adatok időbeli felbontása is kiemelkedőnek tekinthető. Ezen részletes adatok felhasználásával nem csupán a zónák tulajdonságai elemezhetők, hanem a hősziget fejlődése is a korábbiakhoz képest alaposabban vizsgálható. Az éjszakai hőmérsékleti mintázat formája pontosabban megismerhető a nagy felbontású adatok alapján és sürü időközönként követhetjük kialakulásának és leépülésének folyamatát. 
A lokális klímazónák megalkotásának koncepciója alapvetően a léghőmérsékletben megjelenő különbségek kimutatásán alapszik. Azonban az említett városi hőtöbblet nem csak a léghőmérsékletben van jelen, hanem többek között a felszínen is megfigyelhető távérzékelési módszerek alkalmazásával. Ezek alapján felvetődhet a kérdés, hogy a lokális klímazónák közötti termikus különbségek ugyanúgy megjelennek-e a felszín esetében is. Szegeden 2008-ban hajtottak végre légi és földbázisú felszínhőmérséklet méréseket, amelyek kiváló alapot adtak arra, hogy a zónák érvényessége ezen állapothatározó esetében is vizsgálhatóvá váljon. Az említett hőmérsékleti értékek mellett, érdeklődésre tarthat számot, hogy miként alakul az emberi szervezetre gyakorolt hőterhelés az egyes zónákban. Ennek vizsgálata egy, a hőterhelést számszerüsíthető termikus index alkalmazásával valósulhat meg, amely a hőmérséklet mellett több, a humán komfortot befolyásoló állapothatározó együttes hatását mutatja meg. Következésképpen, megadhatók az emberi hőterhelést leginkább erősítő beépítési jellegek, amely információk figyelembevételével a várostervezés során a településeken fellépő hőstressz mérséklése elősegíthető.

A hőterhelés jelenkori nagysága mellett, mindenképpen érdemes a jövőben várható kép megismerése is, hiszen a városokban eleve jelenlévő hőtöbblet mellett a globális klímaváltozás problémáját is szükséges figyelembe venni. A városi népesség növekvő számának ténye pedig egyre inkább indokolja a vizsgálatok jövőre történő kiterjesztését. Így, ha feltérképezzük, hogy a városi területeken a beépítéstől függően hogyan és milyen mértékben módosul a hőterhelés mértéke, felkészülhetünk a ránk váró változásokra. A megszerzett információkat alkalmazhatjuk az adaptációs és mitigációs stratégiák kidolgozásában, segítve ezzel a döntéshozók és várostervezők feladatait.

Dolgozatom első célja a szegedi mérőállomás-hálózat térben és időben részletes adatai alapján a lokális klímazónák közötti termikus különbségek megismerése, amelynek eredményei alkalmazhatók más városokra is. Emellett, a rendszer rugalmasságának feltárása érdekében, további cél az egyes zónákon belüli, az állomások között fellépő különbségek megismerése. A léghőmérséklet vizsgálata mellett érdemes a zónák felszínhőmérsékletre gyakorol hatásait is megadni. Továbbá, a klímazónák közötti, a humánkomfort viszonyokban jelentkező különbségek elemzésével kívánom kimutatni a hőterhelés mérséklésében legkedvezőbb beépítettségi típusokat. Végezetül, a jelen viszonyai mellett célom a ránk váró 21. századi jövőkép lokális, városon belüli részletes aspektusainak megismerése klímamodell alkalmazásával, éghajlati szimulációk adatait felhasználva. 


\section{Irodalmi felvezetés}

\subsection{A városklíma főbb jellegzetességei}

\subsubsection{Városi népesség aránya, várható növekedése}

Az urbanizáció kifejezése alatt minőségi és mennyiségi folyamatokat is értünk. A városodás az urbanizáció mennyiségi folyamata, azaz a városok mennyiségének és méretének változása, míg városiasodásnak például a városi szerkezet és az infrastruktúra fejlődését tekintjük. Történeti urbanizációnak az i. e. 3-4. évezredtől az i. sz. 16. századig terjedő időszakot nevezhetjük. Az akkori társadalmi berendezkedések és a kapcsolódó települések leginkább a termékeny folyó völgyekhez köthetően alakultak ki.

A modernkori urbanizáció kezdetét az ipari forradalom időszakára (17-18. sz.) teszszük. Ekkor az iparosodás hatására bekövetkező munkaerő áramlásnak köszönhetően elsőként az európai nagyvárosok kialakulása történt meg (pl. London, Párizs). Később, a 20. századba lépve előbb Észak-Amerika, majd Japán területén volt szembetünő a változás. Ennek a hullámnak a csúcsa 1950-re tehető, amikor a fejlett régiókban a népesség már megközelítőleg fele élt városokban (Unger et al., 2012).

Az utóbbi évtizedeket az agglomerációk kialakulása jellemezte, amely az urbanizáció második hullámát jelentette. A folyamat elsősorban a fejlődő világban jelentkezett robbanásszerü mértékben. Ezt, a korábbitól sokkal nagyobb növekedést részint a népesség növekedése, másrészt a megélhetési problémák megoldásának keresése okozta. Következésképpen, megnövekedett azon agglomerációk száma, melyek 10 millió fönél is népesebbek és az előrejelzések alapján ez a tendencia a jövőben is folytatódni látszik. Az urbanizáció felvázolt folyamatát a város lakosságának az össznépességhez viszonyított arányszáma tükrözi, amely szerint 1800-ban a teljes népesség 5,1\%-a, 1900-ban 13,3\%a élt városokban $(U N, 1980)$. Ez a szám 1950-ben 29,6\%-ra, 1990-ben már 42,9\%-re növekedett, míg a legújabb elörejelzések szerint 2050-re 66\%-ra fog emelkedni (UN, 2015).

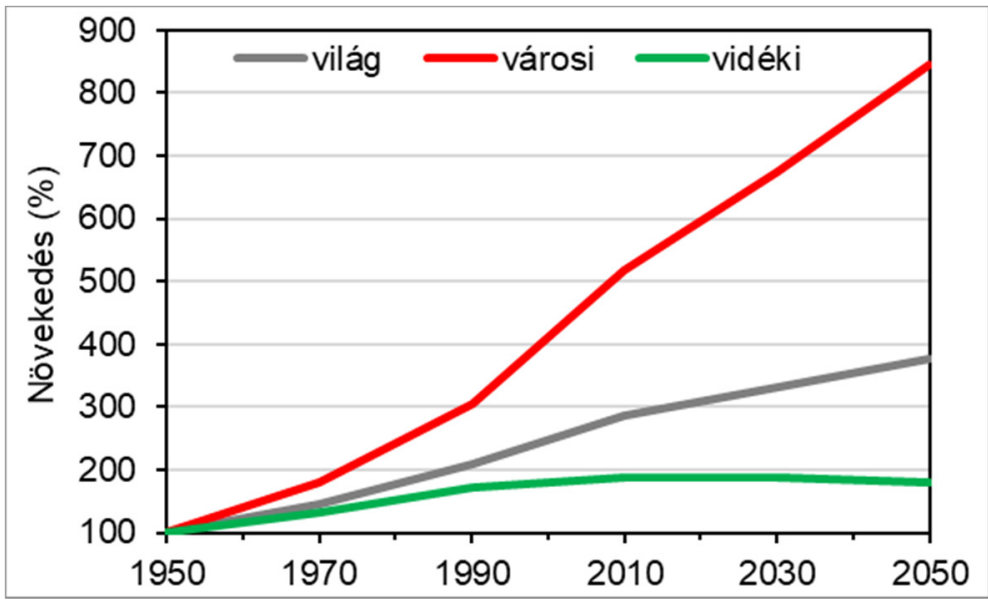

2.1. ábra: A világ népességének növekedése 1950-2050 között $(1950=100 \%)$, külön jelölve a városi és vidéki lakosságot $(U N, 2015)$

A 2.1. ábra a világ, valamint külön ábrázolva a vidéki és városi népesség növekedését mutatja be az 1950-es helyzethez viszonyítva (100\%). Az ábra alapján elmondható, hogy 2050-re a vidéki népesség kb. 1,8-szorosa, a városi népesség 8,5-szöröse lesz az akkori értéknek, ugyanakkor a teljes növekedés közel 4-szeresre várható (377\%). Míg az előre- 
jelzések a városi népesség növekedését mutatják, addig az urbanizáció sebessége a jövőben csökkenni látszik mind a fejlettebb, mind pedig a kevésbé fejlett régiókban (2.1. táblázat). A városi népesség évenkénti változását tekintve látható, hogy az idő elörehaladtával fokozatosan csökken a növekedés üteme. Ez a szám 2,08\% volt 1950 és 1970 között a fejlett régiókban, de 2030 és 2050 között csupán 0,27\%-ra prognosztizálható. A fejletlenebb területeken is hasonló a tendencia, a 20. század közepén még 4,04\%év ${ }^{-1}$ volt a növekedés, azonban ez a jövőben $1,33 \%$ év $^{-1}$-re fog csökkenni (2.1. táblázat).

2.1. táblázat: Városi lakosság számának évenkénti növekedése (\%) az egyes időszakokban 19502050 között, különböző fejlettségű régiók szerint (UN, 2015)

\begin{tabular}{|l|c|c|c|c|c|}
\hline & $\mathbf{1 9 5 0 - 1 9 7 0}$ & $\mathbf{1 9 7 0 - 1 9 9 0}$ & $\mathbf{1 9 9 0}-\mathbf{2 0 1 4}$ & $\mathbf{2 0 1 4}-\mathbf{2 0 3 0}$ & $\mathbf{2 0 3 0}-\mathbf{2 0 5 0}$ \\
\hline Világ összesen & 2,96 & 2,63 & 2,21 & 1,66 & 1,13 \\
\hline Fejlett régiók & 2,08 & 1,06 & 0,69 & 0,45 & 0,27 \\
\hline Kevésbé fejlett régiók & 4,04 & 3,82 & 2,88 & 2,02 & 1,33 \\
\hline
\end{tabular}

\subsubsection{A városklíma kialakulása és a városi légkör szerkezete}

Az előzőekben leírtak alapján láthatjuk, hogy a városi lakosság jövőbeli növekedésének köszönhetően az emberiség egyre nagyobb részét befolyásolják a természetestől eltérő városi környezet sajátosságai. Definíció szerint a városklimatológia a települések és a klíma közötti kölcsönhatásokkal foglalkozó tudományág $(W M O, 1983)$. Ennek alapján a városklíma olyan helyi éghajlatnak tekinthető, amely a beépített terület és a regionális éghajlat kölcsönhatásaként jön létre.

A városok klímájának sajátosságait számos tényező befolyásolja. Fontos szempont, hogy az adott város mely éghajlati zónában helyezkedik el, valamint milyen mérettel és szerkezettel rendelkezik. Emellett meghatározó tényezők a település és környezetének természetföldrajzi adottságai, gondolva itt a domborzatra, a vízparti elhelyezkedésre, illetve a felszínjellegre, mely tulajdonságok erősíthetik vagy gyengíthetik az antropogén hatások mértékét. Ezen hatások föbb okai röviden az alábbiak (Unger, 1997):

- természetes felszínek helyettesítése épületekkel és vízzáró felszínekkel

- a városi felszín összetett geometriája, azaz a vertikálisan és horizontálisan is megjelenő egyenetlenségek széles skálája

- a mesterséges környezet (járdák, utak) anyagai eltérő fizikai tulajdonságokkal rendelkeznek (pl. nagyobb hővezetőképesség és kisebb albedó)

- a városi energiaegyenleg egy új taggal bővül, amely az emberi tevékenység (ipar, közlekedés, fütés) által a környezetbe kikerülő hő

- az ipar, közlekedés és fütés által a légkörbe kerülö vízgőz, füst, gázok és egyéb szilárd szennyezőanyagok, melyek jelentős hatással vannak a sugárzási folyamatokra is.

Fontos megjegyezni, hogy az egyes városok egyedi tulajdonságokkal rendelkeznek, azaz sajátosan módosítják környezetük klímáját. Így a városklímát befolyásoló tényezők szerepe és súlya városonként eltér, hatásuk esetenként egyedinek tekinthető.

A felszín légkörre gyakorolt hatása tulajdonképpen csak a troposzférára korlátozódik, ugyanakkor egy napos intervallumban gondolkodva ez egy vékonyabb réteget érint, amit planetáris, légköri vagy vidéki határrétegnek (rural boundary layer - RBL) nevezünk. Jellemzője az erőteljes átkeveredés, amelynek köszönhetően kapja meg hőenergiájának nagy részét és teljes víztartalmát. A települések feletti légkör szerkezetét el kell különítenünk a természetes felszínek felettiétől. Természetes felszíneknél, azaz az RBL esetében napközben a Nap által felmelegített felszín hatására hőszállítás indul meg, ami a 
határréteg vastagságát 1-2 km-re tolja ki. Éjszaka a földfelszín gyorsabb hülése miatt lecsökken a keveredés és a határréteg 100 m-nél vékonyabbra esik össze (Oke, 1987).

A települések felett alapvetően két réteget különböztethetünk meg: a városi határréteg (urban boundary layer - UBL) lokális vagy mezoskálájú jelenség, míg a városi tetöréteg (urban canopy layer - UCL) folyamatait mikroskálájú, helyspecifikus folyamatok irányítják (2.2. ábra). Az UBL jellemzőit a felszín tulajdonságai és az ott zajló tevékenységek alakítják, alapja a tetőszint körül helyezkedik el, míg magasságát a felszín érdességi folyamatai határozzák meg. Az RBL-lel ellentétben az UBL-ben éjszaka is megmarad az átkeveredés. Nyugodt időjárás esetén a város felett kupolaszerüen helyezkedik el, míg enyhe és közepes erősségü szél esetén „tollként” vagy „fáklyaként” elnyúlik a vidéki határréteg fölött (2.2. ábra). Az UBL két részre osztható, a felső keveredési rétegre és az alsó UCL-re, amely az utcaszint és a különböző objektumok (épületek, fák) teteje között helyezkedik el. Míg a keveredési rétegben a felszín összhatása mutatkozik, addig az UCL-ben az egyes tereptárgyak hatása jelenik meg, így ezt a réteget nagyfokú heterogenitás jellemzi, tulajdonságai kis területen belül is jelentősen változhatnak (Oke, 1976).

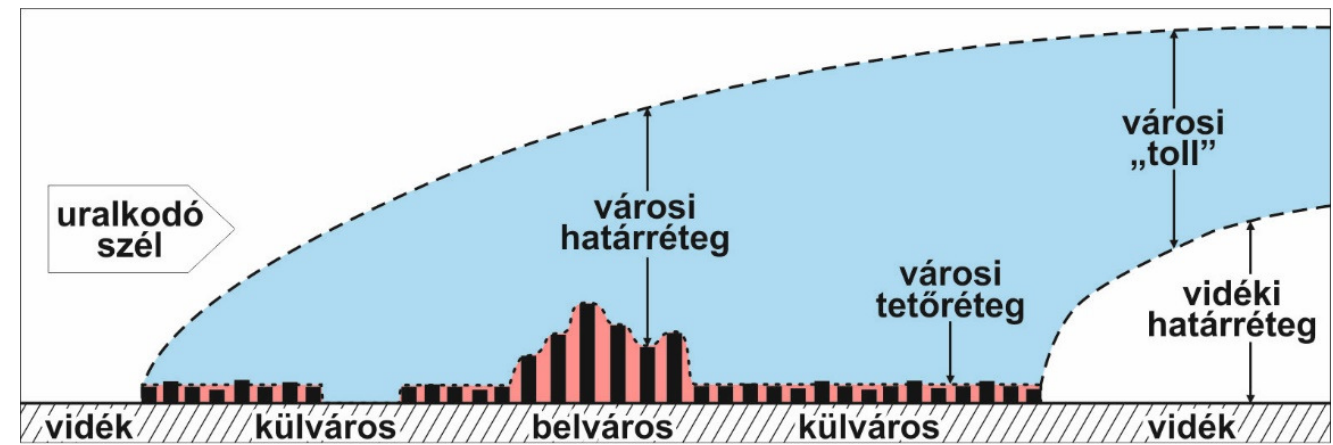

2.2. ábra: A városi légkör szerkezete (Oke, 1976; Unger, Gál, 2017)

\subsubsection{A város sugárzási mérlege és energiaegyenlege}

A városok sugárzási viszonyainak változása két okra vezethető vissza. Egyrészt a szennyezőanyagok feldúsulásának, másrészt a felszín eltérő sugárzási tulajdonságainak és geometriájának köszönhetően változik a települések sugárzási mérlege $(O k e, 1982)$.

A városi szennyezett levegőben a beérkező és visszavert rövidhullámú sugárzás a külterülethez képest erősebben gyengül, számszerüen 2-10\%-kal (Peterson, Stoffel, 1980). A városban viszont az albedó általában 0,05-0,10-dal kisebb (Oke, 1974), így a rövidhullámú sugárzási bevételben nem mutatkozik jelentős különbség a vidéki területekhez képest.

A hosszúhullámú sugárzást befolyásoló folyamatok is hasonlóan kioltják egymást. Ugyanis a hősziget jelenségnek (2.1.4. fejezet) köszönhetően megnövekszik a felszíni kisugárzás, aminek jelentős része elnyelődik a szennyezett és melegebb városi levegőben és újra kisugározódik a felszín felé. Ennek köszönhetően éjjel a hosszúhullámú sugárzási bevétel a városokban nagyobb a külterületekhez képest. Ez a megnövekedett bevétel nappal is fennmaradhat a szennyezőanyagok felmelegítésének következtében. A fentieket összegezve a város és a külterület teljes sugárzási egyenlegének különbsége nem számottevő, mértéke 5\% alatti (White et al., 1978).

A rövidhullámú és hosszúhullámú sugárzási mérlegek összege egyben a felszíni energiaegyenleg $\left(Q^{*}\right)$ kiindulási alapja. Az egyenleg azt írja le, hogy a sugárzási bevétel (vagy kiadás) mire fordítódik:

$$
Q^{*}+Q_{F}=Q_{H}+Q_{E}+\Delta Q_{S}
$$


A 2.1 képletben megjelenik a légkörrel történő hőcsere két formája: az érzékelhető vagy szenzibilis $\left(Q_{H}\right)$, illetve a látens hő $\left(Q_{E}\right)$, mennyiségük egymáshoz való viszonyát a Bowen-arány $\left(Q_{H} / Q_{E}\right)$ fejezi ki. A $\Delta Q_{S}$ az energiatárolás megváltozásnak tényezője. A városokban a vidéki területekhez képest plusz bevételt jelent az antropogén hőtermelés $\left(Q_{F}\right)$. Ez az érték közvetlenül a mérések során nem meghatározható, azonban mennyisége kikövetkeztethető a fütőanyag felhasználás mennyiségéből. Mérsékelt égövön, nyáron a $Q_{F}$ napi értéke $5-50 \mathrm{Wm}^{-2}$ között változhat a külvárostól a belvárosig haladva. Ha az érték a mérési hibahatáron belül esik, akkor elhanyagolhatónak tekinthető (Oke, 1988). Azonban a magas szélességeken, illetve a sürü beépítettségü területeken nő ennek a tényezőnek a jelentősége, ekkor már szükséges számításba venni (Sümeghy, Unger, 2003).

A külterületen és kevésbé beépített területeken a látens és szenzibilis hő a nap folyamán hasonló mértékü, köszönhetően a több zöldfelületnek, de a beépítés növekedésével a látens hő szerepe egyre kisebb lesz (2.2. táblázat). Emellett a mesterséges beépítés tulajdonságainak (kisebb hővezetés, nagyobb hőkapacitás) köszönhetően a városban a hötárolás jelentősen nagyobb lesz. Ez különösen az éjszaka folyamán válik fontossá, amikor is jelentős szerepet játszik a magasabb városi hőmérséklet fenntartásában. Összefoglalva, a városokban az érzékelhető hő és a hőtárolás nő a látens hő rovására, aminek oka az antropogén hőtermelés, illetve a rendelkezésre álló nedvességbeli különbségek. Utóbbiak inkább száraz, csapadékmentes időszakokban jelentősek, ugyanis csapadékhullás közben és után, a külterület és belterület közötti energetikai különbségek elenyészőek.

2.2. táblázat: Az energiaegyenleg összetevőinek arányai a napi sugárzási mérleghez viszonyítva a külterületen, az elővárosban és a belvárosban (Oke, 1982)

\begin{tabular}{|l|c|c|c|}
\hline Beépítettség & $\Delta \mathbf{Q}_{\mathbf{S}} / \mathbf{Q}^{*}$ & $\mathbf{Q}_{\mathrm{H}} / \mathbf{Q}^{*}$ & $\mathbf{Q}_{\mathrm{E}} / \mathbf{Q}^{*}$ \\
\hline Külterület & 0,15 & 0,28 & 0,57 \\
\hline Előváros & 0,22 & 0,39 & 0,39 \\
\hline Belterület & 0,27 & 0,44 & 0,29 \\
\hline
\end{tabular}

\subsubsection{Hőmérséklet-módosulás a városban}

A mesterséges környezet hatására a városokban gyakran hőtöbblet alakul ki a külterületekhez képest, ezt városi hőszigetnek (urban heat island - UHI) nevezzük. A hősziget a város levegőjében, a felszínen, illetve a talaj felső rétegében jelentkezhet. Ezek a különböző szinteken létrejövő hőtöbbletek összefüggenek egymással, de kialakulásuk folyamata, illetve időbeli dinamikájuk eltér egymástól. A levegöben kialakuló hőtöbblet esetén elkülönítjük a határrétegben és a városi tetőrétegben kialakuló hőszigeteket. Dolgozatom az utcaszinten kialakuló, az ember közvetlen környezetében lévő hőszigettel kíván a továbbiakban foglalkozni. A 2.3. táblázat mutatja be azokat a folyamatokat és hatásaikat, amelyek a tetőréteg magasabb hőmérsékletét eredményezik.

A hősziget mértékének leírására a hősziget intenzitást alkalmazzák, ami a város (urban $-u$ ) és a környező területek (rural - r) közötti hőmérséklet-különbséget jelenti $(\Delta T$ vagy $\Delta \mathrm{T}_{\mathrm{u}-\mathrm{r}}=\mathrm{T}_{\mathrm{u}}-\mathrm{T}_{\mathrm{r}}$ ). A tetőrétegben kialakuló hősziget megjelenése kiválóan tükrözi elnevezésének alapját. Izotermáinak formái egy sziget képét alkotják, melyet a vidéki környezet hűvösebb levegője vesz körül (2.3. ábra). A vidéki területektől a belváros felé haladva a hősziget jellegzetes szerkezettel rendelkezik. A település határán a hőmérséklet ugrásszerúen megemelkedik, amelynek nagysága 100 m-enként $0,4^{\circ} \mathrm{C}$ is lehet $($ Oke, 1987). Az ún. ,szirt” után a hömérséklet-emelkedés lelassul, de viszonylag egyenletes marad („fennsík”). A hőmérséklet esetleges csökkenését a parkok, illetve a kevésbé beépített területek okozhatják. A város leginkább beépített területén jelenik meg a hösziget inten- 
zitás maximuma, azaz „csúcsa”. Ez a szabályos forma csak olyan derült, szélcsendes (anticiklonális) időjárási körülmények között jön létre, amelyek kedveznek a kisebb skálájú, lokális folyamatok kialakulásához (és természetesen egy „klasszikus” település esetében, ahol a sürűbb beépítés és a magasabb házak a belső területeken találhatók).

2.3. táblázat: A városi tetőrétegben kialakuló hősziget főbb okai $(\uparrow / \downarrow=$ növekedés/csökkenés) (Oke, 1982)

\begin{tabular}{|l|l|l|}
\hline Változás az energiaegyenlegben & Okozó városi tényező & Városi hatás \\
\hline$\uparrow$ rövidhullámú sugárzás elnyelése & utcageometria & $\begin{array}{l}\text { megnövekedett felszín és } \\
\text { többszörös visszaverődés }\end{array}$ \\
\hline$\uparrow$ hosszúhullámú visszasugárzás & légszennyezés & $\begin{array}{l}\text { nagyobb elnyelés és visz- } \\
\text { szasugárzás }\end{array}$ \\
\hline$\downarrow$ hosszúhullámú sugárzási veszteség & utcageometria & $\downarrow$ égboltláthatóság \\
\hline antropogén hőtermelés & épületek és közlekedés & közvetlen hőtöbblet \\
\hline$\uparrow$ érzékelhető hőtárolás & építési anyagok & $\begin{array}{l}\uparrow \text { hőkapacitás és hővezető- } \\
\text { képesség }\end{array}$ \\
\hline$\downarrow$ látens hőszállítás & építési anyagok & $\downarrow$ evapotranszspiráció \\
\hline$\downarrow$ turbulens hőszállítás & utcageometria & $\downarrow$ szélsebesség \\
\hline
\end{tabular}

A városi hősziget jellegzetes napi menetet mutat. Napnyugta után a városokban kevésbé hül le a levegö, így a hajnali minimum hőmérséklet nem olyan alacsony, mint a külterületen. Azonban a napkelte utáni melegedés a városokban kisebb, így a város levegöje lassabban melegszik fel. A hömérséklet-különbség napnyugta után gyorsan növekszik, maximuma a napnyugta utáni 3-5 órára tehető. Az éjszaka további részében a $\Delta \mathrm{T}$ értékének csökkenése figyelhető meg, ami napkeltekor felgyorsul (Oke, Maxwell, 1975). Napközben a különbség elenyésző, évszaktól függően akár negatív értékek is előfordulhatnak (ún. hűvös sziget), amelyek közepes földrajzi szélességeken jellemzően a melegebb félévben fordulnak elő, míg az év többi részében egész nap pozitív hőmérsékletkülönbségek lépnek fel (Busch, Kuttler, 1990).

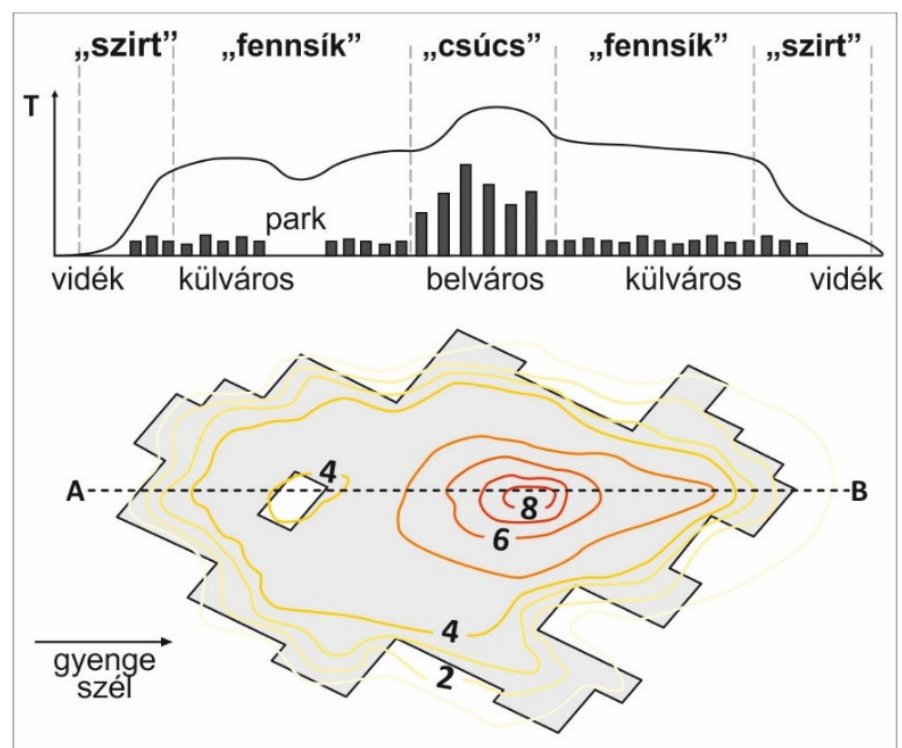

2.3. ábra: A városi hősziget keresztmetszete az A és B pontok között és horizontális szerkezete ideális időjárási körülmények között (Oke, 1976; Unger, Gál, 2017) 
A hősziget közvetlen hatásaként meghosszabbodik a növények vegetációs periódusa és eltolódnak a fenológiai fázisok. Ennek oka, hogy hatására a fagymentes időszak meghosszabbodik, illetve a fagyok intenzitása is csökken. További előnye, hogy télen csökkenti a fütési idény hosszát és a fütésre felhasznált energia mennyiségét (Unger, Makra, 2007).

Ha a regionális áramlási viszonyok gyengék, akkor a hősziget hatására kialakul egy lokális légáramlási rendszer. Kialakulásának feltétele a megfelelő nagyságú horizontális hőmérséklet-különbség, aminek ellensúlyoznia kell a városi felszín erőteljes súrlódási hatását. Amennyiben ez a feltétel adott, akkor a legmelegebb városrész felé felszíni beáramlás jön létre, amelyet vidéki szellőnek nevezünk (Oke, 1987). Iránya éjjel és nappal is a város felé mutat, ugyanis a város nappal a tető-, éjjel az utcaszintben melegebb, mint a külterület. Ennek köszönhetően a vidéki szellő nappal a város felett, éjjel az utcák szintjében jelentkezik (2.4. ábra). A belvárosban egy feláramlási zóna jön létre és a magasabb légrétegekben visszaáramlás történik a külterületek felé. Ezt az áramlási rendszert városi hősziget-cirkulációnak nevezzük (Eliasson, Holmer, 1990).

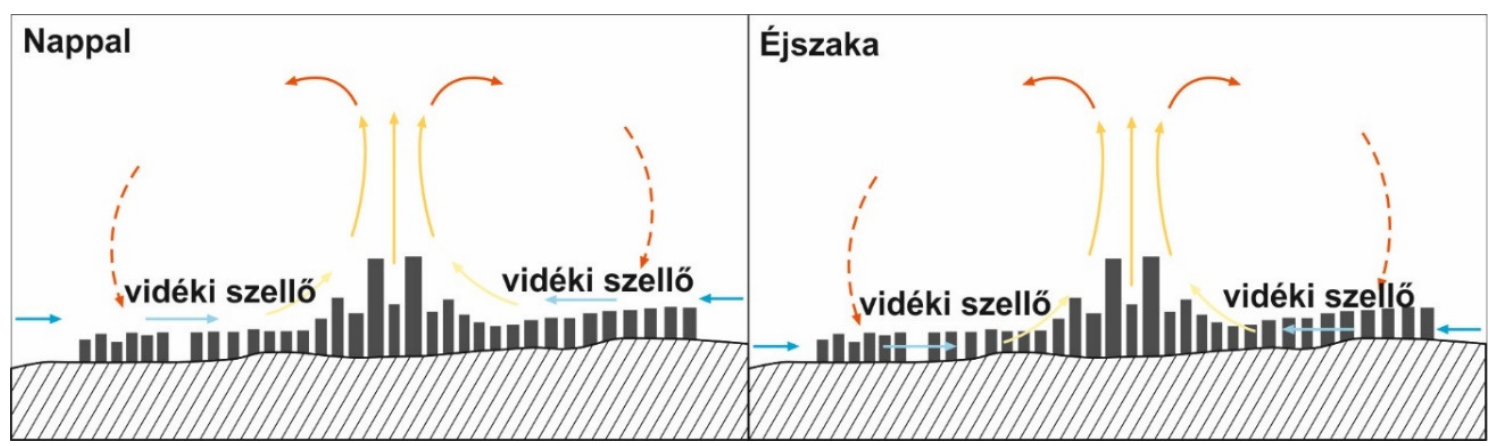

2.4. ábra: A hősziget által generált városi cirkuláció nappal és éjszaka (Noto, 1996; Unger, Gál, 2017)

\subsubsection{A hősziget intenzitását befolyásoló tényezők}

A hősziget maximális intenzitása $\left(\Delta T_{\max }\right)$ és a települések mérete szoros kapcsolatot mutat. A településméret egyik mérőszámának tekinthető népességszám $(P)$ és a város hőszigetének maximális intenzitása között logaritmikus kapcsolat áll fenn. Az európai városok esetén két egyenletet is felhasználhatunk, kisebb különbségük a vizsgálatba bevont városok eltérö jellegéből adódik (Oke, 1973; Park, 1987):

$$
\begin{aligned}
& \Delta T_{\text {max }}=2,01 \cdot \log P-4,06 \\
& \Delta T_{\text {max }}=1,92 \cdot \log P-3,46
\end{aligned}
$$

A hősziget kialakulásánál már említésre került, hogy derült, szélcsendes időjárási körülmények kedveznek létrejöttének, ugyanakkor a nagyobb szélsebesség a kialakult höszigetet gyengítheti vagy akár meg is szüntetheti. A 2.2-2.3 összefüggések alapján a nagyobb városok intenzívebb hőszigetet képesek generálni, így ebből feltételezhető, hogy a nagyobb lélekszámú települések esetében nagyobb szélsebesség szükséges a hösziget megszüntetéséhez. Ezt a szélsebességet kritikus szélsebességnek $\left(u_{k r i t}\right)$ nevezzük és a népességszámmal logaritmikus kapcsolata van (Oke, Hannell, 1970):

$$
u_{k r i t}=3,41 \cdot \lg P-11,6
$$


Az átlagos regionális szélsebesség $(\bar{u})$ és felhőborítottság $(N)$, valamint az intenzitás kapcsolatára elsőként Sundborg (1950) adott meg empirikus formulát, amelyet Uppsala városára dolgozott ki:

$$
\Delta T_{u-r}=(a-b \cdot N) / \bar{u}
$$

ahol $a$ és $b$ a városra vonatkozó állandók. Duckworth, Sandberg (1954) és Chandler (1965) más városok kapcsán is hasonló összefüggésekre jutottak. Oke (1973) a felhőborítottság értékét 0 -nak tekintve, a hősziget intenzitása, valamint a szélsebesség és a népesség közötti kapcsolatra az alábbi összefüggést kapta több város együttes vizsgálata alapján:

$$
\Delta T_{u-r}=1,91 \cdot \log P-2,07 \cdot \bar{u}-1,73
$$

A népességgel jellemzett városméreten kívül figyelembe kell vennünk a világ különböző részeinek eltérő városszerkezeti jellegzetességeit, azaz fontos szempont, hogy a vizsgált településen az alacsony, szellős vagy a magas, tömör beépítettség-e a jellemző. Érdemes megvizsgálni az utcák és az épületek méreteit, azaz a magasság/szélesség arányt (height/width $-H / W$ ) is, amely az épületek átlagos magasságának és az utcák szélességének a hányadosa. A $H / W$ a maximális UHI intenzitással logaritmikus kapcsolatban áll (Oke, 1981):

$$
\Delta T_{\max }=7,54+3,97 \cdot \ln (H / W)
$$

A különféle felszínparaméterek közül a legtöbb irodalom az égboltláthatóság kapcsolatát vizsgálja a felszínközeli légrétegben (UCL) megjelenő hösziget intenzitásával. Az égboltláthatóság (sky view factor - SVF) a látható égbolt és a teljes félgömb felületének arányát jelenti egy adott pontból nézve. A vizsgálatok kimeneteiben nincs teljes egyetértés, míg egyes kutatások szoros kapcsolatot állapítottak meg (Oke, 1981; Johnson, 1985; Park, 1987), addig mások ennek ellenkezőjét jelentették ki (Eliasson, 1992; Upmanis et al., 1998).

\subsection{A lokális klímazóna koncepció kialakulásának folyamata}

Az előző alfejezetben láthattuk, hogy a hősziget intenzitásának mértékét a városi és külterületi hömérséklet-különbség alapján tudjuk megállapítani. Mindazonáltal felmerülhet az a kérdés, hogy mit tekinthetünk városi, illetve vidéki területnek. Erre az objektív választ a szakirodalom sem tudja nekünk egyértelmüen megadni, ugyanis városinak tekinthető a parkban, lakótelepen vagy a felhőkarcolók között elhelyezett mérőállomás is. Hasonlóan kimutatható ez a probléma a vidéki környezetben is: egyaránt vidékinek tekinthetjük a repülőteret, a mezőgazdasági területet, de akár a ritkábban beépített külvárost vagy a nagyváros közelében lévő kisvárost is. Tehát a város és a vidék kifejezések első megközelítésben világos megkülönböztetést tükrözhetnek, azonban a városklíma vizsgálatokban nincsenek egyértelműen definiálva (Stewart, Oke, 2006).

Ez a felvázolt probléma pedig megnehezíti a világ különböző részein elvégzett vizsgálatok összehasonlítását. Továbbá fontos megjegyezni, hogy a város-vidék elnevezés egy mezoskálájú különbségre utal (Oke, 1987), míg ha egy adott városon belül kívánunk vizsgálatot végezni - azaz egy szükebb környezet termikus viszonya- 
ira vagyunk kíváncsiak - akkor lokális skálájú megközelítést kell alkalmaznunk. Ekkor a város-vidék megközelítés nem elegendő, hiszen a fenti példák alapján is láthatjuk, hogy ezek a felszíntípusok egymástól igen eltérők lehetnek és valamennyinek megvannak az egyedi fizikai tulajdonságai, amelyek megjelennek az ott kialakuló klímában.

Amennyiben egy egész várost lefedő mérőállomás-hálózatot kívánunk létrehozni - a város részletes termikus viszonyainak feltárása érdekében - akkor az elemek elhelyezése során hasonló kérdéseket kell megválaszolnunk. Már létező hálózat esetén, többek között, hogy az egyes állomások milyen típusú környezetben helyezkednek el, megállapíthatók-e ennek a környezetnek a jellemzői, illetve az adott állomás menynyire képvisel egy egyértelmüen definiált városi környezetet (Schroeder et al., 2010). Tervezett és kiépítendő hálózat esetén fontos, hogy az adott városban milyen felszíntípusok különíthetők el és ezek elegendő nagyságúak-e ahhoz, hogy az oda telepített állomás erre a területre reprezentatív legyen, minimalizálva a mikrokörnyezet hatását (Unger et al., 2011).

Oke (2004) szerint a város zónákra történő felosztásának az a célja, hogy a várost az eltérő felszínek klímára gyakorolt hatásai alapján osszák fel. Az így létrejött klímazónák fő jellegzetessége, hogy területükön a város(rész) klímamódosító hatása viszonylag homogén, a klímaparaméterek és meteorológiai állapotjelzők módosulása közel egységes. E klímazónák alkalmazásával a város klímamódosító hatásáról szerzett finomított ismeretek beépíthetök a várostervezés folyamatába (Stewart, Oke, 2012), valamint a zónák feltérképezése segítséget nyújthat a városon belüli meteorológiai/klimatológiai méröállomások optimális elhelyezésében is $(O k e, 2004)$.

2.4. táblázat: A klímazónák jellegzetességei Auer (1978) meteorológiai szempontú városi felszínosztályozási rendszerében

\begin{tabular}{|c|c|c|c|}
\hline Típus & Zónák elnevezése & Épületek & Növényzet \\
\hline I1 & Nehézipari & $\begin{array}{l}3-5 \text { emeletes, lapostetős épületek, ipari } \\
\text { létesítmények }\end{array}$ & $<5 \%$ \\
\hline $\mathrm{I} 2$ & Könnyüipari & $\begin{array}{l}\text { Vasútállomások, logisztikai központok, } \\
1-3 \text { emeletes, lapostetös épületek }\end{array}$ & $<5 \%$ \\
\hline $\mathrm{C} 1$ & Kereskedelmi & $\begin{array}{l}\text { Irodák, lakóházak, szállodák, } 10 \text { eme- } \\
\text { letnél magasabb, lapostetős épületek }\end{array}$ & $<15 \%$ \\
\hline $\mathrm{R} 1$ & Lakóházas & Egyszintes, sátortetős lakóépületek & $\begin{array}{l}\text { Jelentős mennyiségü fü, } \\
\text { kevés/közepes mennyi- } \\
\text { ségü fa, > 70\% }\end{array}$ \\
\hline $\mathrm{R} 2$ & Kompakt lakóházas & $\begin{array}{l}\text { Sürủn elhelyezkedő, maximum } 2 \text { eme- } \\
\text { letes, sátortetős lakóházak }\end{array}$ & $\begin{array}{l}\text { Korlátozott mennyiségü } \\
\text { fü és fa, }<30 \%\end{array}$ \\
\hline R3 & Kompakt lakóházas & $\begin{array}{l}2 \text { emeletes, lapostetős családi házak, } \\
\text { közel zárt utcafronttal }\end{array}$ & $\begin{array}{l}\text { Korlátozott mennyiségü } \\
\text { fü és idős nagy méretü } \\
\text { fák, }<35 \%\end{array}$ \\
\hline R4 & $\begin{array}{l}\text { Ritkán beépített } \\
\text { családi házas }\end{array}$ & $\begin{array}{l}\text { Nagy kertekkel rendelkezö családi há- } \\
\text { zak }\end{array}$ & $\begin{array}{l}\text { Nagy méretü füves terü- } \\
\text { let, kevés fa, }>80 \%\end{array}$ \\
\hline A1 & Városi természetes & $\begin{array}{l}\text { Parkok, temetők, golfpályák, ritkán } \\
\text { előforduló épületekkel }\end{array}$ & $\begin{array}{l}\text { Közel teljes növényborí- } \\
\text { tás, }>95 \%\end{array}$ \\
\hline $\mathrm{A} 2$ & Mezőgazdasági & Szántóföldek & $\begin{array}{l}\text { Szántóföldi növényzet, } \\
>95 \%\end{array}$ \\
\hline A3 & $\begin{array}{l}\text { Használaton kívüli, } \\
\text { városi }\end{array}$ & Elhagyott, használaton kívüli területek & $\begin{array}{l}\text { Gyomnövények, kevés } \\
\text { fa, }>90 \%\end{array}$ \\
\hline A4 & $\begin{array}{l}\text { Használaton kívüli, } \\
\text { vidéki }\end{array}$ & Erdők & $>95 \%$ \\
\hline A5 & Vízfelszínek & Tavak, folyók & - \\
\hline
\end{tabular}


A lokális klímazónák (Local Climate Zones - LCZ) (Stewart, Oke, 2012) rendszerének megalkotása előtt már több kísérlet is történt a városi klímazónák osztályozásra. Chandler (1965) munkájában jelenik meg először a város klíma alapú felosztása. Elemzésében Londont osztotta fel négy különböző részre, az egyes részek eltérő klímája és beépítési jellegzetességei alapján.

A továbbiakban Auer (1978) nevéhez köthetö egy városi és vidéki területekre is kiterjedő osztályozás. Módszere az egyik első meteorológiai alapú felosztás, melynek során tizenkét meteorológiailag szignifikáns felszínhasználati kategóriát különített el St. Louis-ban (Missouri), a vegetáció és az épületek karakterisztikái alapján (2.4. táblázat). Osztályozásának fô szempontjai a következők voltak: egyszerü, széleskörüen elfogadott nevezéktan alkalmazása; lehetséges legyen az osztályozási séma átalakítása más területek igényei alapján; lehetőséget ad az induktív generalizálásra. A felmérés alapja alacsony magasságú repülések során készített fényképek kiértékelése volt. A későbbi osztályozások részben ezen a megközelítésen alapulnak.

Ellefsen (1991) nevéhez köthető a városi felszínzónák (Urban Terrain Zones UTZ) rendszere, amelyet 10 amerikai városra alkalmazott. Az osztályozási rendszer alapja az épületek egymáshoz viszonyított és városon belüli elhelyezkedése, funkciója, építésének éve, építőanyagai és magassága, valamint külön koncentrált az utcák alakjára, a parkolók elhelyezkedésére, az épületek helyzetére és sürüségére. Ezek alapján 17 zónát különített el, amelyek az osztályozási rendszerek közül elsőként tükrözték a város struktúráját és az épületek anyagát.

Auer és Ellefsen osztályozási rendszereit Oke $(2004,2008)$ ötvözte a hét osztályból álló városi klímazónák (Urban Climate Zones - UCZ) rendszerében. Célja egy egyszerü, generális osztályozás volt, ami segíti a meteorológiai mérőállomások elhelyezését. A zónák a ritkán elhelyezkedő épületektől a sürü beépítésig tejednek és elkülönítésük a város szerkezete, a vízzáró/vízáteresztő felszín arány, az építési anyagok és az emberi aktivitás alapján történt (2.5 táblázat).

2.5. táblázat: A városi klímazónák (UCZ) jellegzetességei (Oke, 2004)

\begin{tabular}{|c|c|c|c|}
\hline Városi klímazóna & Megjelenés & H/W arány & Beépítettség \\
\hline $\begin{array}{l}\text { 1. Fejlett városi terület, sürün } \\
\text { elhelyezkedö, magas épületekkel }\end{array}$ & & $>2$ & $>90$ \\
\hline $\begin{array}{l}\text { 2. Fejlett városi terület, egymáshoz igen } \\
\text { közel elhelyezkedö, } 2-5 \text { emeletes } \\
\text { épületekkel }\end{array}$ & & $1-2,5$ & $>85$ \\
\hline $\begin{array}{l}\text { 3. Közepes sürüségü városi terület, } \\
\text { különálló, de egymáshoz közel } \\
\text { elhelyezkedő épületekkel }\end{array}$ & 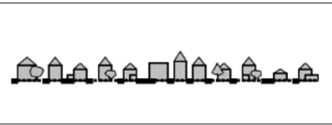 & $0,5-1,5$ & $70-85$ \\
\hline $\begin{array}{l}\text { 4. Közepes vagy alacsony sürüséggel } \\
\text { beépített, nagy alapterületü, alacsony } \\
\text { épületek és parkolók }\end{array}$ & & $0,05-0,2$ & $70-95$ \\
\hline $\begin{array}{l}\text { 5. Kis sürüséggel, } 1-2 \text { emeletes } \\
\text { lakóházakkal beépített, családi házas } \\
\text { területek }\end{array}$ & 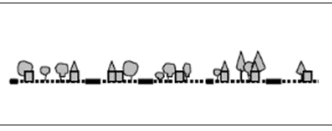 & $\begin{array}{c}0,2-0,6 \\
>1 \text { fák esetén }\end{array}$ & $35-65$ \\
\hline 6. Nagy épületek jelentős zöldfelülettel & A & $0,1-0,5$ & $<40$ \\
\hline $\begin{array}{l}\text { 7. Vidéki beépítés, mezőgazdasági } \\
\text { terület, ritkán elhelyezkedő épületekkel }\end{array}$ & . & $>0,05$ & $<10$ \\
\hline
\end{tabular}

Oke (2004) osztályozása továbbfejlesztésének tekinthető a lokális klímazónák rendszere, amelyben nem csak a városi, hanem a vidéki területek is szerepelnek, megkönnyítve a sokszínű város-vidék klimatológiai eltéréseinek elemzését. A rendszert néhány év alatt fejlesztették ki, a különböző változatok (Stewart, Oke, 2009; 2010) 
letisztulása után érte el végső formáját (Stewart, Oke, 2012). Az osztályozási rendszer alapja a felszín egyes részeinek fizikai-geometriai jellemzők alapján történő elkülönítése. Ezek a jellemzők a felszín termikus reakcióival kapcsolatosak, amelyek alapján objektívan különíthetjük el az egyes osztályokat, ugyanis valamennyi mérhető, valamint nem idő- és helyspecifikus. Legtöbbjük a geometriára és a felszínborítottságra vonatkozik, de van köztük olyan is, ami a felszín termikus és sugárzási viszonyait tükrözi (2.6 táblázat). Az osztályozási rendszer célja, hogy egy mérőállomás esetén lehetséges legyen megadni, hogy környezete milyen mértékben befolyásolja föként termikus szempontból - az ott mért adatokat. Definíció szerint a lokális klímazónák egységes felszínborítású, szerkezetü, anyagú és antropogén hőkibocsátású területek, amelyek horizontális felbontása néhány 100 métertől néhány kilométerig terjedhet (Stewart, Oke, 2012).

2.6. táblázat: A lokális klímazónákat elkülönítő paraméterek, rövidítésük és mértékegységeik típusok szerint (Stewart, Oke, 2012)

\begin{tabular}{|l|l|}
\hline \multicolumn{2}{|c|}{ Paraméterek, típusaik és mértékegységük } \\
\hline Geometriai, felszínborítottsági & Termikus, sugárzási, energetikai \\
\hline égboltláthatóság (SVF) & hőátadási tényező $(\mathrm{SA})\left(\mathrm{Jm}^{-2} \mathrm{~s}^{-1 / 2} \mathrm{~K}^{-1}\right)$ \\
\hline magasság/szélesség arány (H/W) & felszíni albedó $(\mathrm{A})$ \\
\hline épület alapterület arány (BSF) $(\%)$ & antropogén hőkibocsátás $(\mathrm{AH})\left(\mathrm{Wm}^{-2}\right)$ \\
\hline vízzáró felszín arány (ISF) (\%) & \\
\hline vízáteresztő felszín arány (PSF) (\%) & \\
\hline érdességi elemek magassága (HRE) (m) & \\
\hline terepi érdességi osztály (TRC) & \\
\hline
\end{tabular}

A rendszer 17 osztályból áll, melyek közül 10 beépítettséggel (LCZ 1-10, 2.7. táblázat) és 7 felszínborítással (LCZ A-G, 2.8. táblázat) jellemezhető. Elnevezésük alapja egy vagy több megkülönböztető felszínparaméter, ami a legtöbb esetben az épületek magassági/beépítettségi tulajdonságaira (pl. LCZ 1: kompakt beépítés, magas épületek, röviden: kompakt-magas) vagy a felszínborításra (pl. LCZ A: fák, sürü elhelyezkedés, röviden: fák-sürü) utal. A típusok a felszín szezonális vagy időszakos tulajdonságai alapján tovább finomíthatók (pl. lombtalan fák, hótakaró) (2.9. táblázat).

A lokális klímazónák alkalmazásának egy fontos következménye az UHI intenzitás egy új mérőszámának megjelenése. A korábban már említett, város-vidék hőmérséklet-különbség a lokális klímazónák alkalmazásával érvényét veszti. Az új rendszer segítségével az UHI intenzitása egy hőmérséklet-különbség két zóna, pl. LCZ 1 és LCZ D között $\left(\Delta \mathrm{T}_{1-\mathrm{D}}\right)$, nem pedig az általános város-vidék közötti eltérés $\left(\Delta \mathrm{T}_{\mathrm{u}-\mathrm{r}}\right)$. Ezek az LCZ-k közötti hőmérséklet-különbségek könnyebben értelmezhetök, mivel a típusok meghatározzák az adatok származási helyének környezetét, így a hősziget intenzitásának fizikai alapú magyarázata van. A lokális klímazónák segítségével a mérőállomások környezetét egységes rendszerbe sorolhatjuk, ami egyúttal háttérinformációt szolgáltat az egyes mérőállomások adatairól. Ennek köszönhetően lehetővé válik a városokon belüli, valamint a különböző városok közötti objektív alapokon nyugvó termikus összehasonlítás. 
2.7. táblázat: A beépítettséggel jellemezhető lokális klímazónák generalizált megjelenítése, rövidített elnevezésük és fontosabb tulajdonságaik (Stewart, Oke, 2012)

\begin{tabular}{|c|c|}
\hline Lokális klímazóna & Leírás \\
\hline LCZ 1 - Kompakt-magas & $\begin{array}{l}\text { Sürün, magas épületekkel beépített. Nincs növényzet. } \\
\text { Többnyire burkolt felszín. Beton, acél, kő és üveg építö- } \\
\text { anyagok. }\end{array}$ \\
\hline t-közepes & $\begin{array}{l}\text { Sủrűn, közepesen magas ( } 3-9 \text { emelet) épületekkel beépí- } \\
\text { tett. Kevés fa. Többnyire burkolt felszín. Kö, tégla és be- } \\
\text { ton építőanyagok. }\end{array}$ \\
\hline 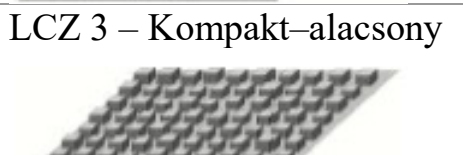 & $\begin{array}{l}\text { Sürün, alacsony (1-3 emelet) épületekkel beépített. Kevés } \\
\text { fa. Többnyire burkolt felszín. Kö, tégla és beton építö- } \\
\text { anyagok. }\end{array}$ \\
\hline LCZ & $\begin{array}{l}\text { Ritkán elhelyezkedő, legalább } 10 \text { emeletes épületek. Nagy } \\
\text { területen fü és fás szárú vegetáció. Beton, acél, kő és üveg } \\
\text { építóanyagok. }\end{array}$ \\
\hline LCZ 5 - Nyitott-k & $\begin{array}{l}\text { Ritkán elhelyezkedő, legalább 3-9 emeletes épületek. } \\
\text { Nagy területeken fü és fás szárú vegetáció. Beton, acél, kő } \\
\text { és üveg építőanyagok. }\end{array}$ \\
\hline $\begin{array}{c}\text { LCZ } 6 \text { - Nyitott-alacsony } \\
\\
20\end{array}$ & $\begin{array}{l}\text { Ritkán elhelyezkedő, alacsony ( } 1-3 \text { emeletes) épületek. } \\
\text { Nagy területeken fü és fás szárú vegetáció. Fa, tégla, kő, } \\
\text { és beton építőanyagok. }\end{array}$ \\
\hline 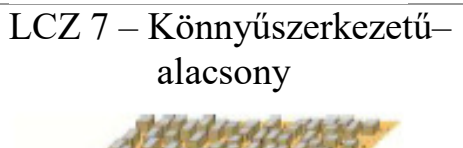 & $\begin{array}{l}\text { Sűrün elhelyezkedő, } 1 \text { emeletes könnyüszerkezetes épüle- } \\
\text { tek. Kevés fa. Felszínborítás többnyire tömörített talaj. Fa, } \\
\text { bádog építőanyagok. }\end{array}$ \\
\hline LCZ 8 - Kiterjedt-alacsony & $\begin{array}{l}\text { Ritkán elhelyezkedő alacsony ( } 1-3 \text { emeletes) épületek. } \\
\text { Kevés fa. Többnyire burkolt felszín. Acél, beton és kő épí- } \\
\text { tőanyagok. }\end{array}$ \\
\hline LCZ 9 - Alig beépített & $\begin{array}{l}\text { Elszórtan elhelyezkedő, kis vagy közepes méretü épüle- } \\
\text { tek. Nagy területeken fü és fás szárú vegetáció. }\end{array}$ \\
\hline LCZ 10 - Nehézipar & $\begin{array}{l}\text { Alacsony és középmagas ipari létesítmények (tornyok, tar- } \\
\text { tályok, kémények). Többnyire burkolt felszín. Fém, acél } \\
\text { és beton építőanyagok. }\end{array}$ \\
\hline
\end{tabular}


2.8. táblázat: A felszínborítással jellemezhető lokális klímazónák generalizált megjelenítése, rövidített elnevezésük és fontosabb tulajdonságaik (Stewart, Oke, 2012)

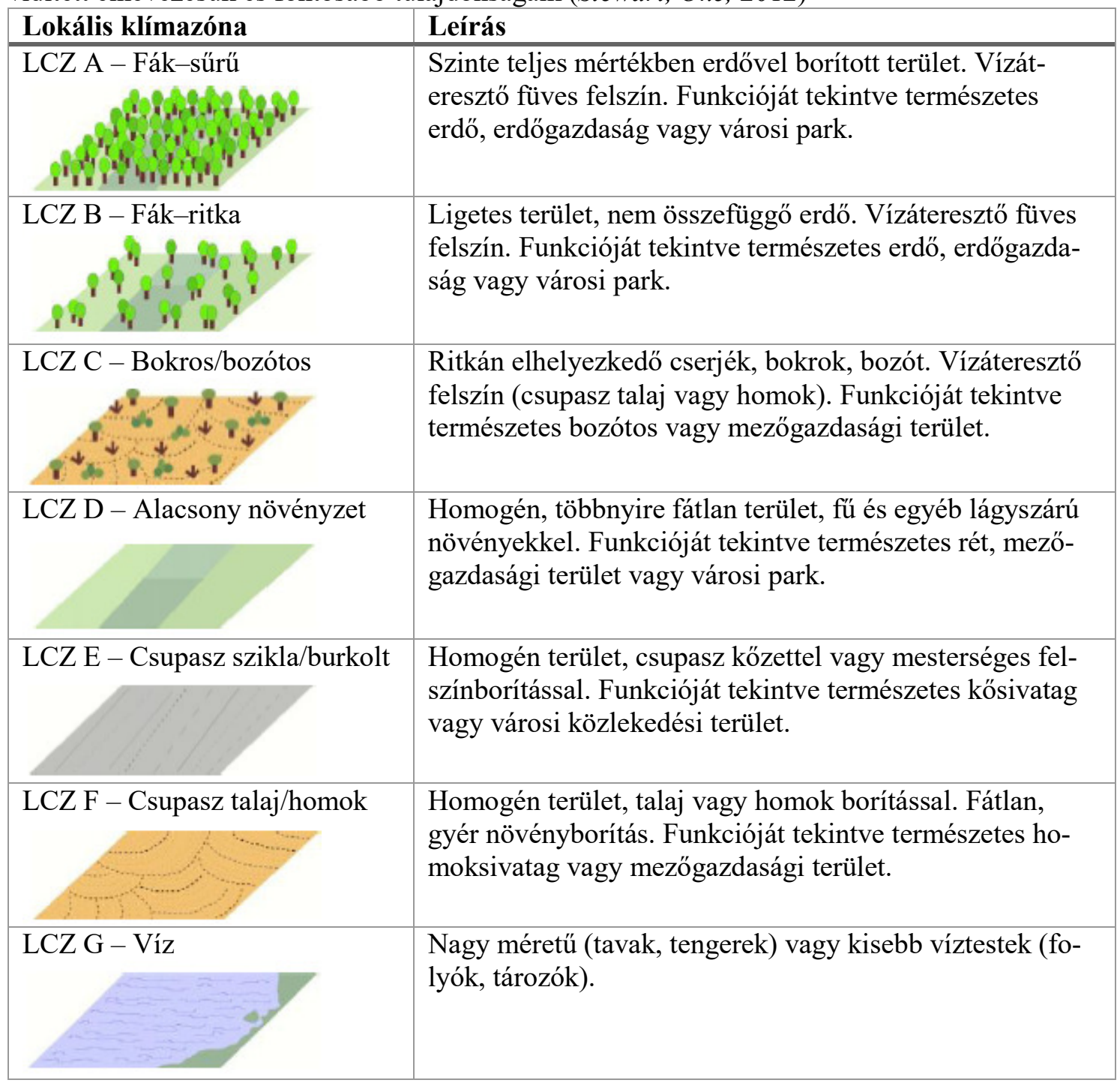

2.9. táblázat: A lokális klímazónák kategóriáinak finomítása időszakos/szezonális felszíni jellemzők alapján (Stewart, Oke, 2012)

\begin{tabular}{|l|l|}
\hline Jellemző & Leírás \\
\hline b. csupasz fák & Levéltelen lombhullató fák (télen), magasabb SVF, kisebb albedó. \\
\hline s. hótakaró & Legalább $10 \mathrm{~cm}$-es hótakaró, kis hővezetés, nagy albedó. \\
\hline d. száraz felszín & Száraz talaj, kis hővezetés, magas Bowen arány, nagyobb albedó. \\
\hline w. nedves talaj & $\begin{array}{l}\text { Vízzel telített talaj, nagy hővezetés, alacsony Bowen arány, kisebb } \\
\text { albedó. }\end{array}$ \\
\hline
\end{tabular}

\subsection{Városi mérőállomás-hálózatok}

A klíma monitorozásához szükséges mérőállomások telepítésének fontosságára már az Éghajlatváltozási Kormányközi Testület (Intergovernmental Panel on Climate Change - IPCC) is felhívta a figyelmet. Megjegyezték, hogy az egyik legfontosabb alapot a klímaváltozás okainak megállapításához a közvetlen mérések adják (IPCC, 2001). A klíma területi és időbeli változásának számszerüsítése egy városban, vagy régióban nem valósulhat meg egyetlen állomás adatai alapján. A városklíma kutatások és a döntéshozatali folyamatok által megkövetelt megfelelő részletességű adatokat kis számú meteorológiai 
állomás nem tudja biztosítani ( $W M O, 2008)$. Az egyetlen eredményes mód a városi környezetek részletes vizsgálatához a megfelelő sürüségü mérőállomás-hálózat. A technológia fejlődésével a mérésekhez használt szenzorok egyre megbízhatóbbak és kevésbé költségesek lettek (Grimmond, 2006; Rundel et al., 2009). Ennek köszönhetően a korábbiakhoz mérten egyre több szenzor elhelyezése lehetővé válik, a mérések minőségének csökkenése nélkül (Muller et al., 2013).

Fontos megemlíteni, hogy ezek a városokban telepített állomáshálózatok többnyire nem üzemelnek folyamatosan. Ennek oka, hogy igény szerint gyakran változhat a megvalósítás technikai háttere, illetve finanszírozása, esetleg a mérési kampány célja is (Grimmond, 2006). A rövid ideig tartó mérési kampányok gyakoribbak, ekkor az adatgyüjtés néhány hétig, hónapig vagy esetlegesen pár évig tart (Watkins et al., 2002; Thepvilojanapong et al., 2010; Banon, Hernandez, 2013; Schatz, Kucharik, 2014). Európán kívül, a világ különböző területein számos hosszabb időtávon müködő hálózat üzemel, pl: Tokió, Japán (Mikami et al., 2003), Szöul, Dél-Korea (Kim, Baik, 2005; Lee et al., 2017), Taipei, Tajvan (Chang et al., 2010), Oklahoma, Egyesült Államok (Basara et al., 2011), Hong Kong, Kína (Hung, Wo, 2012) és Minneapolis-St. Paul, Egyesült Államok (Smoliak et al., 2015).

Ezek közül talán az egyik legismertebb az Oklahomában telepített mérőállomás-hálózat (Oklahoma City Micronet), amelyet a város légköri monitorozásához terveztek ( $\mathrm{Ba}$ sara, 2008). A 40 elemből álló mérőállomás-hálózat 4 mezoskálájú állomásból és 36 közlekedési jelzőlámpán elhelyezett állomásból áll (Basara et al., 2010; 2011). Előbbiek az egész Oklahoma államot lefedő, 110 állomásból álló hálózat részeit képezik (McPhearson et al., 2007). A városban megközelítőleg minden 3 km-re esik 1 állomás és az adatgyüjtés valós időben 1 , míg a mezoskálájú hálózatnál 5 percenként történik. Utóbbi hálózathoz tartozó állomások több mint 20 különböző változót mérnek, mint pl.: szélsebesség 2 és $10 \mathrm{~m}$-en, léghőmérséklet 1,5 és $9 \mathrm{~m}$-en, légnedvesség és légnyomás. Ezek a szenzorok egy 10 méteres tornyon vagy annak környezetében vannak elhelyezve. Hasonló állomások telepítése a központi területeken nem volt lehetséges az összetett felszín és az állomások magas költsége miatt, ezért a további 36 állomást 9 méteres magasságban helyezték el és Vaisala WXT510 szenzorokat alkalmaztak. Kommunikációjuk megoldása érdekében egy teljes várost lefedő Wi-Fi hálózatot hoztak létre. A külvárosi és vidéki területekhez képest a városközpontban nagyobb területi sürüségben telepítettek állomásokat úgy, hogy a környező területükre reprezentatívak legyenek. Telepítésük során nem játszott szerepet az állomások klímazónák szerint történő elhelyezése, az ezekbe történő besorolást utólag adták meg Auer (1978), Ellefsen (1991), Oke (2004) és Stewart, Oke (2009) osztályozásai alapján (Basara et al., 2011).

Tokióban 2002-ben telepítettek egy kiemelkedő nagyságú, 120 automatizált méröállomásból álló hálózatot (Mikami et al., 2003). A METRO (Metropolitan Environmental Temperature and Rainfall Observation System) 20 állomása valós idejű hőmérséklet, légnedvesség, szélsebesség, szélirány, csapadék és légnyomás adatokat biztosított 10 percenként. Ezen állomások fő célja a városi tetőréteg felett uralkodó szélmezők vizsgálata volt, így a szenzorokat az épületek tetején helyezték el. A hálózat másik része 100 darab léghőmérséklet, légnedvesség mérő szenzorból állt, amiket általános iskoláknál telepítettek. A hálózat müködése 2005-ig tartott, majd ezután az Extended-METROS elnevezésű rendszert hozták létre, amelynél a hőmérséklet-mérések feldolgozása 2006-ban kezdődött meg. A megközelítőleg 200 szenzorból álló hálózat állomásai kb. 7 km-enként helyezkednek el, azaz egy állomás megközelítöleg $50 \mathrm{~km}^{2}$ területet fed le (Honjo et al., 2015). 
Nagy állomássürüsége miatt érdemes még kiemelni a Szöulban kialakított hálózatot (Lee et al., 2017). A város $605 \mathrm{~km}^{2}$-es területén 295 automata időjárási állomás található egyenlően elosztva, sürüségét tekintve megközelítőleg minden $2 \mathrm{~km}^{2}$-re esik egy állomás. Az állomásokat három különböző szervezet üzemelteti, valamennyi hitelesített, a szabványnak megfelelő mérőeszközzel rendelkezik, amelyek léghőmérséklet, légnedvesség, szélirány és szélsebesség adatokat biztosítanak. Ezen a rendszeren felül még a szöuli kormány üzemeltet egy régebben fennálló kb. 30 állomásból álló hálózatot $(B o o, O h$, 2000; Kim, Baik, 2005; Hong et al., 2013).

Ugyanakkor Európában csupán néhány kiépített mérőállomás-hálózat található (2.10. táblázat). Az alábbiakban ezeknek részletesebb bemutatása következik.

2.10. táblázat: Európában telepített állomáshálózatok jellemzői

\begin{tabular}{|l|c|c|c|}
\hline \multicolumn{1}{|c|}{ Város, ország } & $\begin{array}{c}\text { Méröállomások } \\
\text { száma }\end{array}$ & Lefedett terület & Állomássürüség \\
\hline Birmingham, Anglia & 111 & $270 \mathrm{~km}^{2}$ & $\sim 1 / 2 \mathrm{~km}^{2}$ \\
\hline Berlin, Németország & 10 & $890 \mathrm{~km}^{2}$ & $\sim 1 / 89 \mathrm{~km}^{2}$ \\
\hline Firenze, Olaszország & 35 & $100 \mathrm{~km}^{2}$ & $\sim 1 / 3 \mathrm{~km}^{2}$ \\
\hline Rotterdam, Hollandia & 14 & $780 \mathrm{~km}^{2}$ & $\sim 1 / 55 \mathrm{~km}^{2}$ \\
\hline Varsó, Lengyelország & 35 & $517 \mathrm{~km}^{2}$ & $\sim 1 / 2 \mathrm{~km}^{2}$ \\
\hline Athén, Görögország & 25 & $2929 \mathrm{~km}^{2}$ & $\sim 1 / 117 \mathrm{~km}^{2}$ \\
\hline
\end{tabular}

A birminghami állomáshálózat (Birmingham Urban Climate Laboratory - BUCL) három különböző rendszerből tevődik össze (2.11. táblázat). Fő elemei az automata időjárás állomások (automatic weather stations - AWS), amelyek 24 Vaisala WXT520 szenzorból (pontossága $\pm 0,3{ }^{\circ} \mathrm{C} 20^{\circ} \mathrm{C}$-on) és Skye Instruments SKS 1110 piranométerből állnak. A BUCL része 4 Met Office/WMO állomás, amelyek területileg durva felbontással rendelkeznek, megközelítőleg 1 állomás $70 \mathrm{~km}^{2}$-re esik. Az összesen 28 állomás közül 23 belterületen, 5 külterületen helyezkedik el (2.5. ábra). A müszerek léghőmérsékletet, relatív nedvességet, szélsebességet, szélirányt, légnyomást, csapadékot és sugárzást mérnek 15 másodpercenként, az adattovábbítás óránkén történik (Chapman et al., 2015).

Az AWS-ek telepítésének fő célja az volt, hogy a várost megfelelően lefedjék, valamint egy adott állomás a város egy helyi, lokális területét jellemezze. Elhelyezésük 3 méter magasan történt, amely a WMO szabványtól (WMO, 2008) nem tér el jelentősen, ugyanakkor a müszerek biztonságosan vannak elhelyezve. Az állomások többségét iskoláknál helyezték el, mivel ezek a müszerekre nézve védett területek és területük reprezentatívak saját környezetükre. Az iskoláknál történő méröállomás-elhelyezés máshol is népszerü (pl.: Vancouver (Wiebe, 2012), London (OPAL; Davies et al., 2011), Tokió (Yamato et al., 2009)).

2.11. táblázat: A birminghami mérőállomás-hálózat felépítése (Chapman et al., 2015; Warren et al., 2016)

\begin{tabular}{|l|c|c|}
\hline Hálózat & Állomások száma & Állomás sürüség \\
\hline Met Office/WMO időjárás állomások & 4 & $\sim 1 / 70 \mathrm{~km}^{2}$ \\
\hline Vaisala WXT időjárás állomások & 24 & $\sim 1 / 10 \mathrm{~km}^{2}$ \\
\hline Hőmérséklet szenzorok (ASM) & 84 & $\sim 1 / 3 \mathrm{~km}^{2}$ \\
\hline
\end{tabular}

A BUCL harmadik része több mint 80 alacsony költségü, vezetéknélküli Aginova Sentinel Micro (ASM) típusú léghőmérséklet szenzorból áll, amelyek közvetlenül képesek kapcsolódni a már meglévő, a városokban egyre gyakoribbá váló Wi-Fi hálózatokhoz (2.11. táblázat, 2.5. ábra), így a kommunikációs költségük igen alacsony. A hálózat nagy 
térbeli és időbeli felbontással rendelkezik és közel valós idejü adatokat biztosít, névleges pontosságuk $< \pm 0,22{ }^{\circ} \mathrm{C}\left(-25-30{ }^{\circ} \mathrm{C}\right.$ között $)$. A legtöbb ASM-t Wi-fi hálózattal rendelkező iskoláknál helyezték el, emellett lámpaoszlopokra, útjelző táblákra, villanyoszlopokra és a 3 m-t elérő kapukra telepítettek szenzorokat (Chapman et al., 2015).

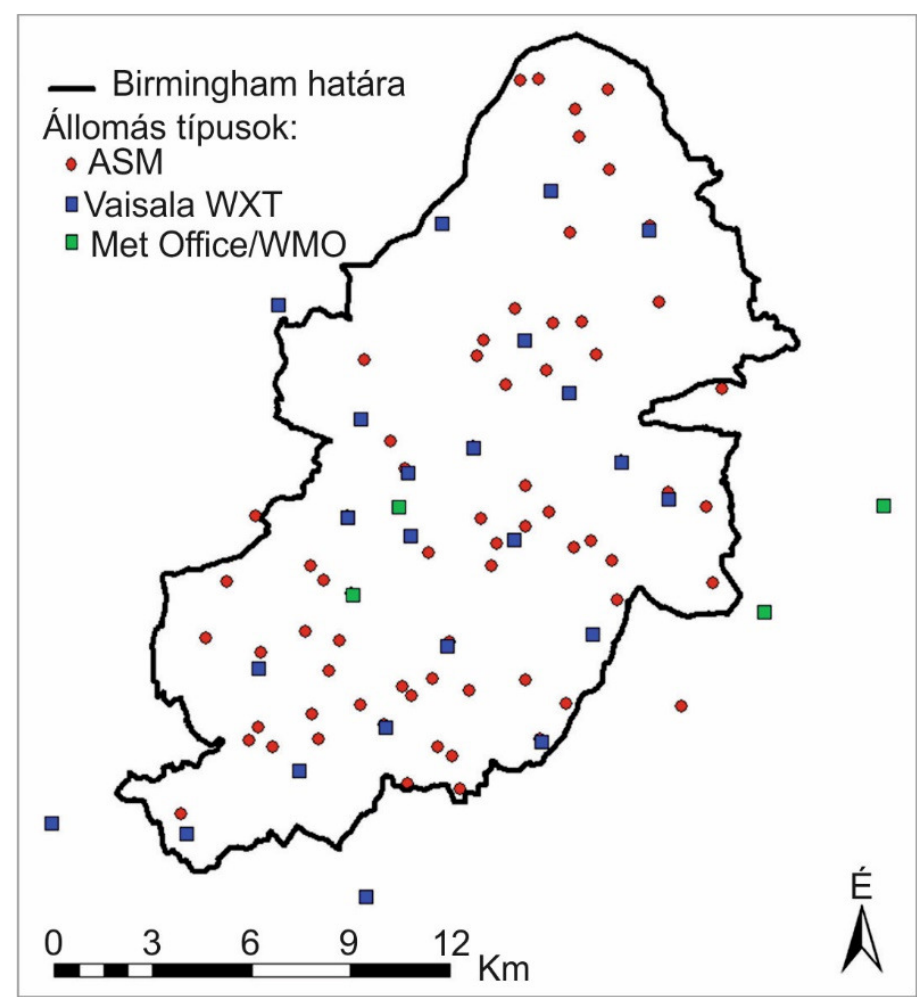

2.5. ábra: Birmingham mérőállomás-hálózata (a hőmérséklet szenzorok (ASM) esetében az iskoláknál elhelyezettek van jelölve) (Chapman et al., 2015)

A birminghami hálózat méréseinek célja a város hősziget struktúrájának térbeli-időbeli elemzése, a városi morfológia hatásának vizsgálata, valamint a modell adatok kiértékelése volt (Chapman et al., 2015). Később ez az eredeti cél átalakult és a méréseket a lakossági forrású, ún. crowd-sourced és müholdas adatok értékeléséhez használták (Warren et al., 2016). Azevedo et al. (2016) müholdképek alkalmazása mellett 82 ASM és valamennyi Vaisala szenzor adatát felhasználták a tetőrétegben és a felszínen kialakuló UHI kapcsolatának vizsgálatakor 2013 nyarán. Warren et al. (2016) a hálózat fenntartásának karbantartási feladatai kapcsán Wi-Fi hálózati problémák megjelenését említik, amelyek megakadályozták az ASM szenzorokat a kommunikációban. Igy a továbbiakban a hálózat fenntartásához szükséges pénzügyi forrásaikat, valamint a karbantartáshoz szükséges időt a Vaisala állomások fenntartására fordították. Bassett et al. (2016) hősziget advekció vizsgálatában már csak a Vaisala és a 4 Met Office állomások adatait használták fel. A teljesség kedvéért szükséges megjegyezni, hogy utóbbi két vizsgálat esetében az állomáshálózat a kezdetitől eltérően már 25 Vaisala szenzorral rendelkezett.

Berlin városklíma hálózata 10 mérőállomásból áll és üzemeltetéséért a Technische Universität Berlin felel (Fenner et al., 2017). A városi környezet léghőmérsékletre gyakorolt hatását először 2001 és 2010 között vizsgálták 5 mérőállomás alapján, amelyek közül három beépített területen (DESS, ROTH, TIER) és kettő a beépített városi területen kívül (DAHF, JAGE) található (2.6. ábra). A hőmérséklet mérése automatikusan és szinkronban történt valamennyi állomáson 5 percenként, a mérések névleges hibája szen- 
zortól függően $\pm 0,2{ }^{\circ} \mathrm{C}$ volt $20^{\circ} \mathrm{C}$-on. Ekkor az állomások szenzorjai különbözőek voltak, amelyek DAHF, JAGE, TIER állomások esetében Vaisala HMP35A, DESS és ROTH esetében Pt100 1/3 DIN Class B típusúak voltak (Fenner et al., 2014).

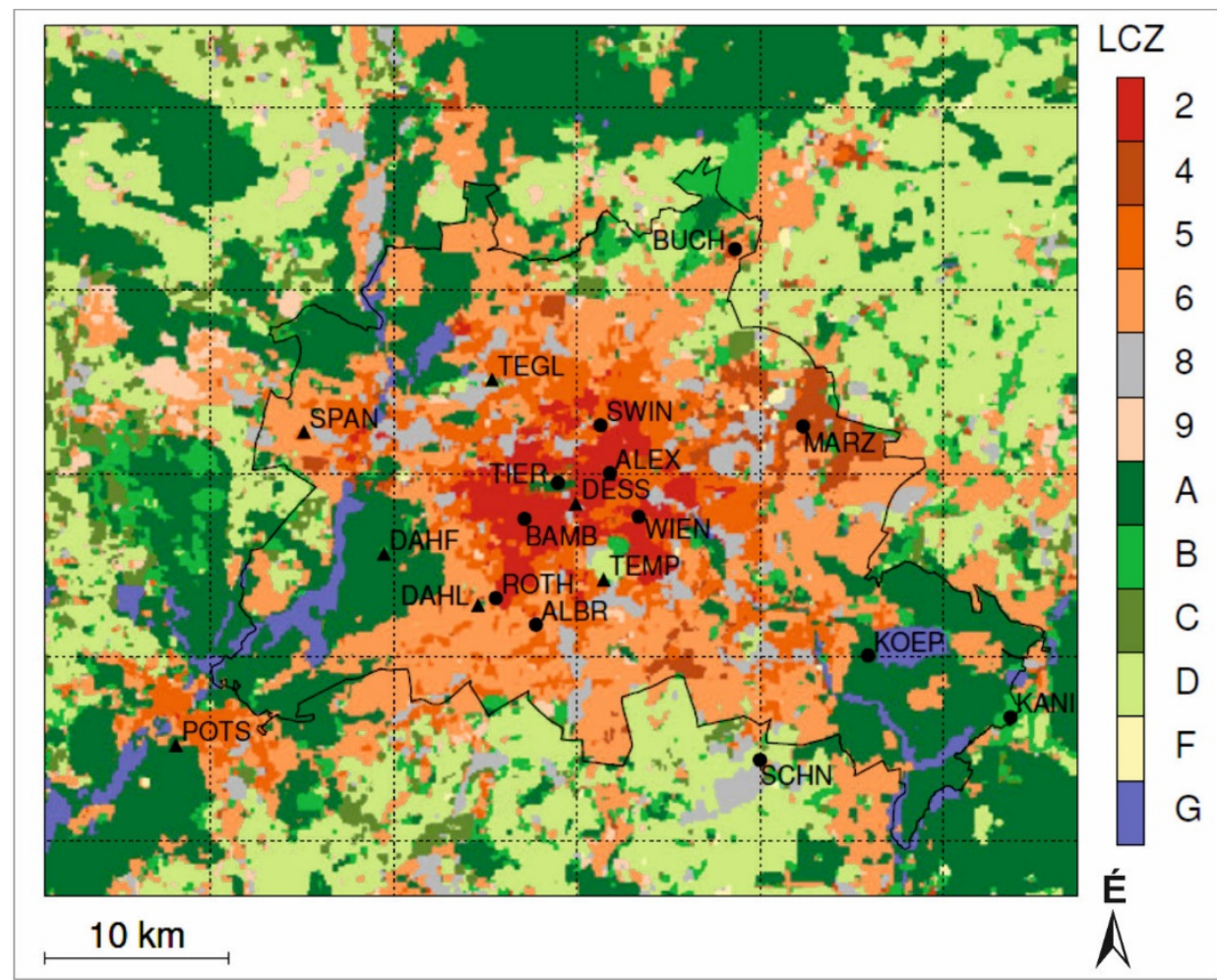

2.6. ábra: Berlin és környezetének lokális klímazónái, valamint a teljes állomáshálózat elhelyezkedése (Fenner et al., 2017)

Az állomáshálózat adatait a továbbiakban egyrészt modellezési vizsgálatok eredményeinek kiértékeléséhez (Kuik et al., 2016; Jänicke et al., 2017), másrészt a lakosság által üzemeltetett meteorológiai állomások referenciájaként használták (Meier et al., 2017; Fenner et al., 2017). Az állomások hőmérséklet és relatív nedvesség szenzorjai már ezekben a vizsgálatokban egységesen Campbell Scientific CS215 típusúak, amelyek pontossága a hőmérsékletre nézve $\pm 0,4{ }^{\circ} \mathrm{C}$, az $5-40{ }^{\circ} \mathrm{C}$ közötti tartományon belül. Árnyékolásukról egységesen fehér radiációs ernyők gondoskodnak, valamint a napsütötte időszakokban a ventilációjuk is biztosított. Míg Kuik et al. (2016) csak 6 állomás, Jänicke et al. (2017), Meier et al. (2017) és Quanz et al. (2018) 8 állomás adatát alkalmazták, addig Fenner et al. (2017) valamennyi állomás adatát felhasználták, a Deutscher Wetterdienst 9 állomásával kiegészítve. A Bechtel-módszer (3.1.2. fejezet) alapján a vizsgált terület osztályozását és valamennyi állomás lokális klímazónákba sorolását is elvégezték (2.6. ábra), amely a következöképpen alakul: LCZ 2: 4, LCZ 4: 1, LCZ 5: 2, LCZ 6: 4, LCZ A: 3, LCZ B: 2 és LCZ D: 3. Az állomások 2 méteren mérik a hőmérsékletet - a fentebb bemutatott - DESS $(3,5 \mathrm{~m})$, valamint BAMB $(2,5 \mathrm{~m})$ és WIEN $(33,6 \mathrm{~m})$ állomásokat leszámítva.

Firenzében 2004 óta üzemel egy 35 elemü mérőállomás-hálózat. A szenzorokat a városi területen belül véletlenszerüen, megközelítőleg 2 méter magasan és az épületektől 2 méteres távolságban telepítették úgy, hogy a beépített területekre nézve reprezentatív méréseket kapjanak. A szenzorok léghőmérsékletet és relatív nedvességet mérnek, burkolt felszínen és zöld területen egyaránt megtalálhatók (Petralli et al., 2011). Az adatgyüjtők HOBO PRO típusúak, működésük tartománya a léghőmérséklet esetében -30 és $50{ }^{\circ} \mathrm{C}$ (felbontása $0-40{ }^{\circ} \mathrm{C}$ között $0,2{ }^{\circ} \mathrm{C}$ ), a relatív nedvesség esetében $0-100 \%$ közötti. 
A léghőmérséklet mérése automatikusan történik 15 percenként. Vizsgálataikban 25 szenzor adatait vizsgálták részletesebben, amelyeket az alapján választottak ki, hogy elhelyezkedésük a város szerkezeti sajátosságait visszaadja, illetve hosszabb időszakra ( 5 év) rendelkezésre álló adatmennyiségük legyen (Petralli et al., 2014). Petralli et al. (2011) órás adatok alapján napi, havi indexeket és hütési, valamint fütési fokszámot számítottak. Petralli et al. (2014) a nyári évszakban elemezték a városon belüli minimum és maximum hőmérsékleteket és az egyes várostervezéshez köthető indikátorokat, amelyek a növényzetet, épületeket és utcákat jellemzik.

A rotterdami mérőállomás-hálózat 2009-ben kezdte el müködését 4 állomással, amelyet a következő évben további 10-zel bővítettek (van Hove et al., 2015). A kezdeti állomásokat az akkori hősziget modellezésük validációjához alkalmazták (Heusinkveld et al., 2014). Az így kialakított hálózat 13 állomása beépített területen, 1 pedig vidéki környezetben helyezkedik el, mint referencia állomás. A Campbell Scientific típusú állomások sugárzási szenzorral, sugárzási ernyővel árnyékolt hőmérővel és higrométerrel, valamint anemométerrel vannak ellátva. A hőmérsékletmérés $0,4{ }^{\circ} \mathrm{C}$, a relatív nedvesség mérés $10-90 \%$ között $2 \%$ pontosságú. A müszerek 2 méteres oszlopokon helyezkednek el, amin a hőmérséklet és légnedvesség mérési magassága 1,5 m, míg a szélsebesség és szélirány mérése 2 méteren történik. Az állomások közül hat esetben a müszert tetőn helyezték el, így a mérési magasság 5-6 méter körül alakul, míg egy állomás a kikötő egy mólóján található, mérési magassága $4 \mathrm{~m}$. Az állomások többsége kompakt lokális klímazónákban helyezkednek el, 1-1 a LCZ 1 és LCZ 2, míg 8 az LCZ 3-t jellemezi. A többi 4 állomás környezete különbözö: 1-1 tartozik LCZ 6, 8, 9 és D-be. Van Hove et al. (2015) az állomáshálózat 3 éves adatsora alapján vizsgálták a helyi, lokális klíma sajátosságait és a kültéri humán komfort viszonyokat.

Varsóban 2001-2002 között történt az első kísérlet méröállomás-hálózat kialakítására, amikor egy projekt keretében 12 HOBO Pro típusú adatgyüjtő monitorozta a léghőmérsékletet és légnedvességet 13 hónapon keresztül (Błażejczyk, 2002). A következő hálózat kialakítása 2006-ban kezdődött el, üzemeltetéséről több intézmény gondoskodik (Kuchcik et al., 2014). 2010-ben a hálózat már 28 állandó automata állomásból állt, amelyek közül 20 található a városban, míg 8 Varsó külterületén helyezkedik el. A müszerek léghőmérsékletet és légnedvességet mérnek 2 méter magasan elhelyezve. Emellett még 7 állomást további 3 különböző intézet üzemeltet, így létrehozva egy 35 elemü hálózatot. Az állomások eloszlása lokális klímazónánként a következő: LCZ 2: 5, LCZ 3: 1, LCZ 4: 4, LCZ 5: 11, LCZ 6: 5, LCZ 8: 1, LCZ 9: 4, LCZ B: 3 és LCZ D: 1. Kuchcik et al. (2014) a hálózat alapján 2011 és 2012 között vizsgálták a hösziget évszakok szerinti alakulását különböző eredetü légtömegek esetében.

Giannopoulou et al. (2011) néhány szóban ismertetik Athén tágabb környezetében telepített ideiglenes mérőállomás-hálózatukat. Az összesen 25 helyen telepített állomásuk egy éven át rögzített adatokat (2008. december - 2009. december). Mivel a hálózat nagy területet fedett le, így sürüsége $\left(\sim 1 / 117 \mathrm{~km}^{2}\right)$ nem mondható kiemelkedőnek. Az állomások kalibrált, nagy pontosságú léghőmérséklet szenzorokkal voltak ellátva, árnyékolásukról Stevenson hőmérőház gondoskodott, a mérések 15 perces gyakorisággal történtek. Giannopoulou et al. (2011) nyáron elemezték a hősziget tulajdonságait Athén 5 különböző földrajzi zónájában az állomáshálózat adatai alapján.

\subsection{A humán bioklimatológia főbb vonatkozásai}

A különböző időjárási körülmények hatást gyakorolnak az élőlények szervezetére, amelynek kutatásával a bioklimatológia tárgya foglalkozik. E tudományterületen belül a 
légkör és az emberi szervezet közötti kapcsolatot a humán bioklimatológa vizsgálja ( $M a-$ yer, 1993).

Az emberi szervezet és környezete között létrejövő energiacsere-folyamatok leírása nem egy felszínre vagy rétegre történik, mint a város esetében (2.1 egyenlet), mivel a függőleges energiaáramok mellett az oldalirányúak is nagy jelentőséggel bírnak. A test sugárzási mérlegét $\left(Q^{*}\right)$ az általa kibocsátott és elnyelt sugárzások határozzák meg:

$$
Q^{*}=I+D+E+B
$$

ahol I a napból közvetlenül érkező direkt, $D$ a szóródott (diffúz) és visszavert (reflektált) rövidhullámú sugárzás, $E$ a környezet és $B$ a test hosszúhullámú kisugárzása (Höppe, 1984; Mayer, Matzarakis, 1998).

A megadott $\mathrm{Q}^{*}$ része az emberi szervezet energiaegyenlegének, amelynek tagjai $\mathrm{W}$ ban vagy egységnyi felületre nézve $\mathrm{Wm}^{-2}$-ben vannak megadva:

$$
M+W+Q^{*}+Q_{C}+Q_{S W}+Q_{D}+Q_{R E}=\Delta Q_{S}
$$

Az egyenletben az emberi test által termelt hőt az $M$ metabolikus ráta (a táplálék oxidációjával keletkező energia) és a $W$ (az izomzat által elégetett tápanyag energiatartalmának egy része), az ún. külső munka adja meg. A 2.9 egyenlet többi része a test és környezete közötti hőcsere folyamatokat írja le: $Q_{C}$ a testfelszín érzékelhető hőárama, $Q_{S W}$ a verejték elpárolgásához, $Q_{D}$ a börön keresztüldiffundáló vízpárához köthető látens hőveszteség és $Q_{R E}$ a légzéshez kapcsolódó turbulens höcsere (Höppe, 1984; Mayer, Matzarakis, 1998).

Szabadtéri tartózkodás esetén (leginkább napsütéses időjárási körülmények között) a bemutatott energiaegyenleget leginkább a sugárzási folyamatok befolyásolják. Ennek egyszerü megadása érdekében vezették be a rövid-és hosszúhullámú sugárzási komponensek hatását egy mérőszámban összegző átlagos sugárzási hőmérsékletet $\left(\mathrm{T}_{\mathrm{mrt}}\right)$. Definíciója szerint annak a képzelt, fekete testként sugárzó buroknak az egységes hőmérséklete, ami a benne lévő emberi testre ugyanolyan sugárzási bevételt eredményez, mint a valódi környezet (Höppe, 1992; VDI, 1998).

A humán bioklimatológia fö problémaköre a légköri környezet emberi szervezetre gyakorolt hatásának (fiziológiai stressz vagy komfortérzet befolyásolása) számszerüsítése. Ennek megadására kezdetben egy-egy meteorológiai paramétert vagy azok kombinációját alkalmazták (Thom, 1959; Steadman 1971; Ali-Toudert, 2005). Ezeket az empirikus közelítéseket váltották fel később az emberi test energiaegyenlegén alapuló modellek (Höppe, 1993), melyek közül az első jelentősebb a Klima-Michel-modell (KMM) volt, amely Fanger (1972) komfort és Jendritzky et al. (1979) sugárzási egyenletén alapul. A KMM-ből számítható a hőérzet várható értéke (Predicted Mean Vote - PMV; Fanger, 1972) és az érzethőmérséklet (Perceived Temperature - PT; Jendritzky et al., 2000; Staiger et al., 2012) elnevezésü termikus indexek. A PMV célja annak számszerüsítése, hogy az emberek egy nagyobb csoportja milyen értéket választana hőérzetének jellemzésére egy standard skálán. Azonban ez az index nem megfelelő a változékony szabadtéri termikus viszonyok leírására, így elsősorban zárt terek klimatikus mérőszámaként alkalmazható (Nikolopoulo et al., 2001; Höppe, 2002, Thorsson et al., 2004), a PT viszont referencia körülményei miatt inkább tekinthető kültérinek. A KMM modellnél szélesebb körben alkalmazhatók azok a modellek, amelyek a test termikus viszonyainak valósághübb leírását adják meg (Höppe, 1993). Ezek közül az egyik a szabadtéri felhasználásra is alkalmas MEMI (Munich Enegy-balance Model for Individuals; Höppe, 
1984), amely Fanger modelljéhez képest több, az emberi testre nézve meghatározó faktort vesz figyelembe.

A KMM és MEMI modellek statikusak, azaz olyan esetekben alkalmazhatók, amikor a vizsgált személy energiaegyenlege stabilizálódik, így a hőtárolás nem változik meg. Ezzel szemben a dinamikus modellek már képesek a változó környezeti feltételeket is figyelembe venni. Ezek körül a két legjelentősebb az IMEM (Instationary Munich Ebergy-Balance Model; Höppe, 1985) és a Gagge-féle két csomópontos modell (Gagge et al., 1971), amelynek neve az emberi szervezet 2 szegmensre történő egyszerüsítésére utal. Utóbbi modell segítségével számítható ki az új effektív hőmérséklet (Gagge et al., 1971). Ez az index jól alkalmazható akkor, ha az alanyok személyes reakciói a fontosak, ugyanakkor ezen ok miatt objektív méröszámként nem alkalmazható, azaz nem általánosítható. Ennek továbbfejlesztett változatai a standard effektív hőmérséklet és a szabadtéri standard effektív hőmérséklet, amelyekben standardizálják az emberre jellemző paramétereket (de Dear, Pickup, 2000; Pickup, de Dear, 2000). Ezeknek az ún. ekvivalens hömérséklet típusú indexeknek nagy elönye, hogy a laikusok számára könnyebben értelmezhetők, mivel összevethetők a személyes tapasztalatokkal. A vizsgálatomban (7. fejezet) használt fiziológiailag ekvivalens hömérsékletet (Physiologically Equivalent Temperature-PET; Mayer, Höppe, 1987; Höppe, 1999) kifejezetten szabadtéri alkalmazásra fejlesztettek ki és az egyik leggyakrabban használt ekvivalens hőmérséklet típusú index, ami a MEMI (és IMEM) modell eredményeként nyerhető (bővebben lásd 3.4. fejezet).

\subsection{Globális és regionális éghajlati modellek}

Az éghajlati modellek napjaink kutatásainak nélkülözhetetlen részét képezik, ugyanis a 21. századi klímaváltozás vizsgálatában kulcsszerepet játszanak. A légköri általános cirkulációs modellek (atmospheric general circulation model - AGCM) a légkör háromdimenziós időbeli változását szimulálják. A légkör állapotát olyan változók írják le, mint hőmérséklet, nyomás, nedvesség, szél, valamint a víz és a jég kondenzálódása a felhőkben. Ezen változók folytonos mezőjét rácspontokban adják meg, amelynek felbontása az elérhető számítástechnikai kapacitások függvénye. A vertikális rácstávolság általában két nagyságrenddel kisebb $(0,1-1 \mathrm{~km})$, mint a horizontális $(10-100 \mathrm{~km})$ (Bartholy, Pongrácz, 2013). A horizontális irányú impulzus-, hö- és vízszállítást általában az alkalmazott rácshálózaton értelmezik, míg ezeknek vertikális szállítását parametrizálják. A legfontosabb parametrizációk a felhőképződésre és a konvektív folyamatokra, valamint a légköri határréteg turbulens kicserélődési folyamataira vonatkoznak. A modellek a légkört ideális gázként kezelik és a légkör alsó 25-30 km-es rétegére helyezik a hangsúlyt (Bader, 2008). Az óceáni általános általános cirkulációs modellek (oceanic general circulation model - OGCM) esetében is több nagyságrenddel nagyobb a horizontális méret, mint a vertikális, továbbá az óceán összetett geometriáját is figyelembe kell venni a modellezésében (Bader, 2008).

A légkör-óceán általános cirkulációs modellek (atmosphere-ocean general circulation model - AOGCM) (Randall et al., 2007) jelenleg a legösszetettebb éghajlati modellek és a globális klímamodellek (global climate model-GCM) legfejlettebb osztálya. Korlátjuk a nagy számításigény, ugyanakkor az éghajlati elemek leginkább valósághủ reprezentációját adják. Az AGCM-ekhez hasonlóan az OGCM-ek a csatolt éghajlati modellek csak egy részét alkotják. A legelső globális klímamodellekben a talajmodellek csak peremfeltételeket biztosítottak az AGCM-ek számára, így egy kétdimenziós felületként kezelték őket (Manabe, 1969). Az egyre növekvő számú mérési adatnak köszönhetően a talajmodellek jelentős fejlődésen mentek keresztül. Ennek ellenére ezek a részmodellek adják a leginkább eltérő eredményeket. 
Ha a globális klímamodellekre tipikusan jellemző felbontásnál (125-400km között) finomabb felbontást szeretnénk elérni, akkor valamilyen leskálázási módszert kell alkalmaznunk. Ez kétféle módon történhet, hiszen beszélhetünk statisztikai és dinamikai leskálázási módszerekről, vagy használhatjuk ezeknek kombinációját. A dinamikai leskálázás a finomabb felbontású modellek, legtöbbször a regionális klímamodellek (regional climate model - RCM) alkalmazását jelenti (Giorgi, Mearns, 1991). Emellett lehetséges még változó rácsfelbontású modellek (Déqué, Piedelievre, 1995) és egyenletesen finom felbontású légköri GCM-ek használata (May, Roeckner, 2001). Empirikus vagy statisztikai leskálázás esetén mérési adatsorok alapján megállapított összefüggéseket használunk fel. Előnye, hogy kevés számítástechnikai kapacitást igényel, ugyanakkor jó minőségü és hosszú időtartamra vonatkozó mérési adatsorra van szükség. Emellett viszont az a feltételezés, hogy a múltban érvényes statisztikai összefüggések igazak maradnak a jövő esetlegesen változó klímájára is, nem feltétlenül helytálló.

A regionális klímamodellek tipikusan egy kontinensre vagy annál kisebb területre vonatkoznak. Ennek következtében szükség van határfeltételek megadására, amelyet a GCM-ek biztosítanak. A 2.7. ábra a GCM-ek és RCM-ek közötti különbségeket mutatja be, ahol látható, hogy a GCM nem képes a felszíntípusok megkülönböztetésére és az orográfia megfelelő figyelembevételére. Az RCM-ek viszont megbízható fizikai tartalommal és nagy felbontással rendelkeznek, de a Földnek csak egy kisebb, korlátos tartományán vannak értelmezve. Elönyük, hogy míg az egyes GCM-ek között a csapadék szimulációjánál jelentősebb különbségeket találunk, addig az RCM-ek esetében nagyobb az egyezés (Bartholy, Pongrácz, 2013).

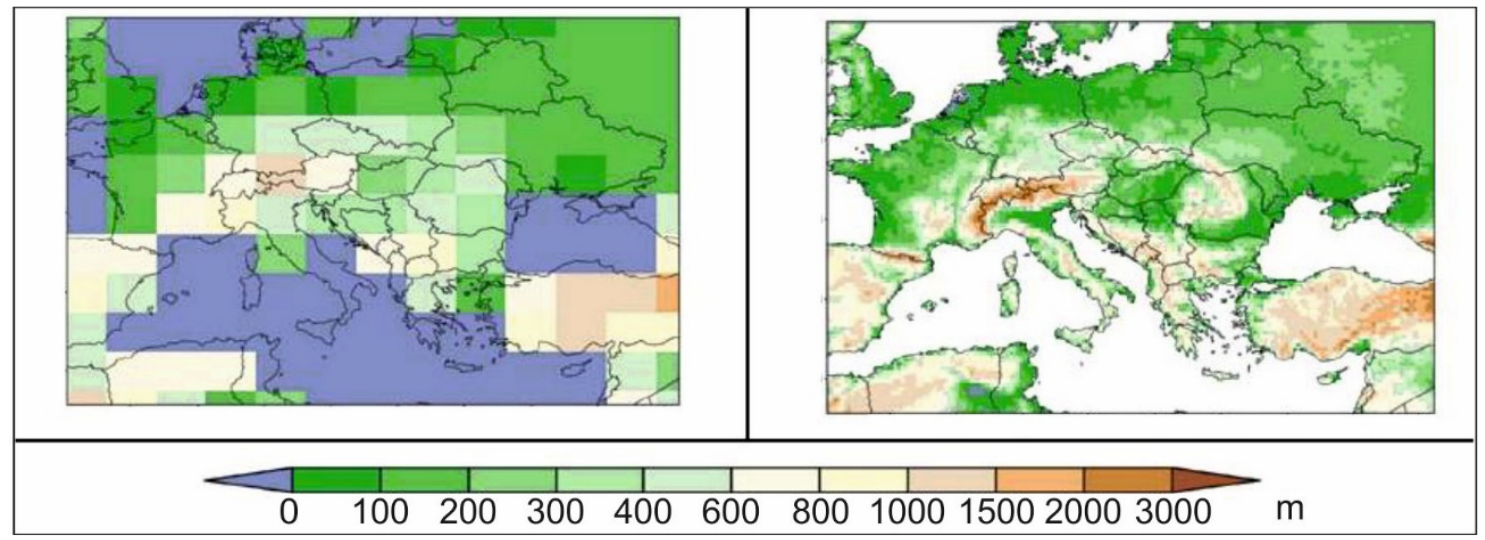

2.7. ábra: A globális és regionális klímamodellek eltérő rácsfelbontásának egy példája (Bartholy, Pongrácz, 2013)

\subsubsection{Kibocsátási forgatókönyvek}

Az egyes kibocsátási szcenáriók megalkotásának célja a globális cirkulációs modellekben történő alkalmazás volt, az éghajlatváltozási vizsgálatok fejlesztésének érdekében. Az IPCC által 1992-ben kiadott úgynevezett IS92 szcenáriók akkoriban úttörőnek számítottak. Ezek voltak az első szcenáriók, amelyek az üvegházgázok koncentrációjának becslését írták le (IPCC, 1992). 1996-ban az IPCC szükségesnek látta a kibocsátási szcenáriók egy új sorának fejlesztését. Ezek az újabb kibocsátási forgatókönyvek (Special Report on Emissions Scenarios - SRES) szintén a jövőbeli üvegházgáz kibocsátások környezeti és klimatikus következményét határozták meg (Nakicenovic, Swart, 2000). A SRES szcenáriók leírása a jövőbeli emissziók fő meghajtóinak széles skáláját fedi le, a demográfiai tényezőktől a technológián át a gazdasági tényezőkig. 
A két IPCC jelentésben is (IPCC, 2001, 2007) megjelenő forgatókönyvek négy kibocsátási alapszcenárió esetére adják meg a várható társadalmi és gazdasági változásokat. Az A1, B1, valamint az A2, B2 szcenárió párok rendre a globalizációs folyamatok felgyorsulását, illetve a régiók szerinti fejlődést vetítik elő. Ugyanakkor az A1 és A2 szcenáriók esetén a gyors gazdasági fejlődés jelentős, míg a B1 és B2 esetén a környezettudatos technológiáké a főszerep. Az üvegházgázok emissziója és a klímaváltozás mértéke alapján az A2 tekinthető a legpesszimistábbnak és a B1 a legoptimistábbnak. Az A1 szcenárión belül további 3 alszcenárió különíthető el: A1FI a fosszilis energiahordozók, A1T a megújuló energiaforrások, valamint A1B mindkettő kiegyenlített használatát feltételezi (Nakicenovic, Swart, 2000).

A SRES kibocsátási forgatókönyveket napjainkban felváltják a reprezentatív koncentráció menetre vonatkozó RCP (Representative Concentration Pathway - RCP) szcenáriók (Moss et al., 2008, 2010; van Vuuren et al., 2011). Habár a korábbi SRES szcenáriók felhasználása széleskörü és eredményekben gazdag volt, újabb és korszerübb forgatókönyvek megalkotására volt szükség. Ennek oka, hogy közel egy évtizednyi új adat állt rendelkezésre a gazdaságról és az újabb technológiákról, valamint megfigyelések olyan környezeti faktorokról, mint a földhasználat- és földborítás-változás, amely információk beépíthetők az új szcenáriókba. Továbbá, a hagyományos klímastratégia nélküli szcenáriók mellett, a különböző mértékü mitigáció hatását megmutató forgatókönyvekre is igény volt (Moss et al., 2010).

2.12. táblázat: Az új, reprezentatív koncentráció menetre vonatkozó szcenáriók jellemzői Moss et al. (2010) és IPCC (2013) alapján

\begin{tabular}{|c|c|c|c|}
\hline Elnevezés & $\begin{array}{c}\text { Sugárzási kényszer válto- } \\
\text { zása* és menete }\end{array}$ & $\begin{array}{c}\mathbf{C O}_{2} \text { ekvivalencia } \\
\mathbf{2 1 0 0 - b a n}\end{array}$ & $\begin{array}{c}\text { Átlag felszín hömérsék- } \\
\text { let-változás 1986-2005 } \\
\text { és 2081-2100 között }\end{array}$ \\
\hline RCP8.5 & $\begin{array}{c}+8,5 \mathrm{Wm}^{-2} 2100-b a n, \\
\text { majd növekedés }\end{array}$ & $\sim 1370 \mathrm{ppm}$ & $3,7^{\circ} \mathrm{C}$ \\
\hline RCP6.0 & $\begin{array}{c}+6,0 \mathrm{Wm}^{-2} 2100-b a n, \\
\text { utána stabilizáció }\end{array}$ & $\sim 850 \mathrm{ppm}$ & $2,2{ }^{\circ} \mathrm{C}$ \\
\hline RCP4.5 & $\begin{array}{c}+4,5 \mathrm{Wm}^{-2} 2100 \text {-ban, } \\
\text { utána stabilizáció }\end{array}$ & $\sim 650 \mathrm{ppm}$ & $1,8^{\circ} \mathrm{C}$ \\
\hline RCP2.6 & $\begin{array}{c}+3 \mathrm{Wm}^{-2} \text {-es } 2100 \text { előtti } \\
\text { csúcs, majd csökkenés }\end{array}$ & $\sim 490 \mathrm{ppm}$ & $1,0^{\circ} \mathrm{C}$ \\
\hline
\end{tabular}

*Az értékek az iparosodás előtti szinthez viszonyítva értendők

Ezek az új forgatókönyvek nem közvetlenül társadalmi és gazdasági tényezőkön alapulnak, mint a korábbi SRES szcenáriók, hanem koncentrációkat és kibocsátásokat határoznak meg. A négy RCP szcenárió korábbi, már publikált kibocsátási szcenáriókból lett kiválasztva (Meinshausen et al., 2011). Egy közülük mitigációs szcenárió, ami nagyon alacsony sugárzási kényszert eredményez (RCP2.6), kettő konstans koncentrációt eredményező, stabilizációt mutató szcenárió (RCP4.5/RCP6.0), míg egy magas koncentrációkat ad (RCP8.5) (van Vuuren et al., 2011). Elnevezésükben a sugárzási kényszer változására utalnak, azaz számértékük az jelzi, hogy adott szcenárió alapján mekkora lesz a várható változás 2100 -ban az iparosodás elötti értékhez viszonyítva (2.12. táblázat). A sugárzási kényszer becslése az üvegház gázok és egyéb befolyásoló anyagok koncentráció növekedésének figyelembevételével történt.

Az IPCC ötödik helyzetértékelő jelentésében már az RCP szcenáriók eredményeit alkalmazták (IPCC, 2013). A jelentés szerint az RCP2.6 szcenárió kivételével a globális felszínközeli hőmérséklet a 21 . század végére valószínüleg meghaladja az $1,5^{\circ} \mathrm{C}$-ot az 1850-1900 időszakhoz képest. Az RCP6.0 és RCP8.5 esetében ez a különbség valószínü, 
hogy a $2{ }^{\circ} \mathrm{C}$-ot is eléri. Az 1985-2005 időszakhoz képest a 2016-2035 időszakban ez a változás $0,3{ }^{\circ} \mathrm{C}$ és $0,7^{\circ} \mathrm{C}$ között várható (2.8. ábra). A század végén, 2081-2100-ban az egyes RCP szcenáriók alapján a hőmérséklet-változás a következő határokon belül mozoghat: $0,3-1,7{ }^{\circ} \mathrm{C}(\mathrm{RCP} 2.6), 1,1-2,6^{\circ} \mathrm{C}$ (RCP4.5), 1,4-3,1 ${ }^{\circ} \mathrm{C}$ (RCP6.0) és $2,6-4,8^{\circ} \mathrm{C}$ (RCP8.5) (IPCC, 2013).

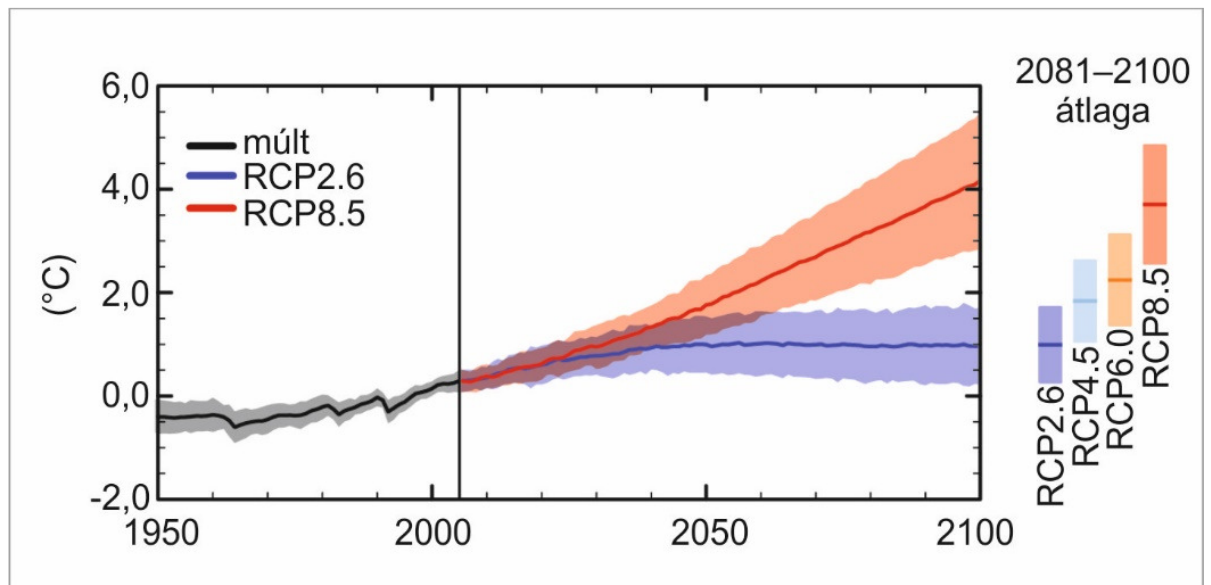

2.8. ábra: A globális felszínközeli hőmérséklet változása 1950 és 2100 között, több modellszimuláció alkalmazásával (IPCC, 2013)

Habár az RCP szcenáriók nem a SRES szcenáriókra épülnek, összehasonlításuk során hasonló 21. századi hőmérséklet elörejelzések mutathatók ki. Az RCP8.5 hőmérséklet előrejelzése az A1FI-nek feleltethető meg, míg az RCP6.0 és RCP4.5 sorrendben a B2höz és B1-hez hasonlítható (Rogelj et al., 2012). Az ENSEMBLES projektben alkalmazott A1B szcenárió által előrejelzett hömérséklet-növekedés megközelítőleg az RCP6.0nak felel meg.

Az RCP-k további újdonsága a korábbi szcenáriókhoz képest, hogy nemcsak 2100-ig futnak, hanem egészen 2300-ig kiterjesztették őket. Mivel ezeket a kiterjesztéseket más módszerekkel alkották meg, külön elnevezést kaptak (Extended Concentration Pathways - ECP). A meghosszabbítás oka a több évszázadot átívelő előrejelzések iránti igény volt, a klíma és az óceán hosszútávú kölcsönhatásainak kutatása érdekében (Meinshausen et al., 2011).

Ezen új szcenáriók alapján Közép- és Dél-Európa térségére Bartholy et al. (2015) és Pongrácz et al. (2016), a Kárpát-medencére Pieczka et al. (2017) vizsgálták a hőmérséklet és csapadék várható változását évszakonként. Az említett európai térségre Bartholy et $a l$. (2017) elemezték a hőmérséklethez és csapadékhoz köthető extrémumok változását is.

\subsubsection{Klímaváltozást vizsgáló projektek}

Az IPCC harmadik helyzetértékelö jelentésében (Third Assessment Report - TER) megfogalmazott nagy felbontású, modellalapú klíma-előrejelzések iránti igény indította el a több tudományterületen átívelő projektek sorát. A TER-ben a regionális klímamodellekkel történő szimulációkat kívánták kiterjeszteni egyre több területre, így a különböző modellekkel és szcenáriókkal végzett együttes szimulációk végrehajtását szorgalmazták (IPCC, 2001).

A PRUDENCE (Prediction of Regional scenarios and Uncertainties for Defining EuropeaN Climate change risks and Effects) projekt ezeket az igényeket kívánta megvalósítani európai skálán. A projekt 2001 novemberétől 2004 októberéig tartott 9 ország 21 
kutatócsoportjának részvételével az Európai Bizottság finanszírozásával. A projekt elsődleges célja nagy felbontású klímaváltozási adatok biztosítása volt a 21 . század végére (2071-2100), Európa területére, klímamodellek dinamikai leskálázásával. A projekt középpontjában az extrém időjárási események vizsgálata állt, ugyanis a korábbi modellezésen alapú kutatások az alacsony felbontású adatok miatt ilyen irányokban korlátoltak voltak. A PRUDENCE eredményei megadták a tudományos hátteret ezeknek a kutatásoknak (Christensen, Christensen, 2003; Schär et al., 2004). Megmutatták, hogy az RCM alapú szcenáriók alkalmazása jelentős előnyöket mutat a korábbi AOGCM alapú szcenáriókkal szemben. Ugyanakkor az RCM-ek alkalmazása nem jelent mindig megoldást, hiszen a csak RCM alapú eredmények térben jelentősen korlátoltak (Christensen et al., 2007). A regionális klímamodellekben jelentkező fő bizonytalanságok okai a kibocsátási forgatókönyv megválasztása és a meghajtó globális klímamodell (Christensen, Christensen, 2007). Mivel az egyes klímaprojekciók a modellekben lévő parametrizációk, a kibocsátási szcenáriók hiányosságai, illetve a modellek felbontása miatt bizonytalansággal terheltek, így változékonyságuk több, különböző modell együttes kezelését igénylik.

A PRUDENCE projektben 4 AGCM és 8 RCM eredményeit használták fel, amelyek közül a modellek többsége az A2, míg néhány a B2 szcenáriót alkalmazta. Pár kivételtől eltekintve a regionális klímamodellek horizontális rácstávolsága $50 \mathrm{~km}$ volt (néhány esetben 20, illetve $10 \mathrm{~km})$. A projekt létrejöttekor nagy felbontású (150 km) AGCM-ek álltak rendelkezésre, míg a légköri sugárzási kényszereket és a megfelelő felszín-tenger határfeltételeket durva felbontású AOGCM-ek adták $(300 \mathrm{~km})$. Ezek a globális eredmények biztosították a kezdeti és határfeltételeket a finom felbontású regionális modelleknek, amelyek nagy felbontású eredményei az orográfiai hatások és a földfelszín-tenger határ jobb leírását biztosítja (Christensen et al., 2007). A nagy időbeli és térbeli felbontást kombinálva lehetővé válik az olyan fizikai és dinamikai folyamatok kezelése, mint az extrém eseménynek számító intenzív csapadékhullás. A szimulációk a jelen (kontroll) időszakra történő alkalmazásával pedig a klímaváltozás becslését tudjuk megadni a modell kimenetek használatával (Jacob et al., 2007). A klímamodellek eredményei nyilvánosan elérhetők a projekt honlapján 2006 óta.

A PRUDENCE projekthez csatlakozott két másik, szintén az Európai Bizottság által finanszírozott projekt. A STARDEX és a MICE projektek vezetését a Kelet-Angliai Egyetem végezte. A STARDEX a statisztikai leskálázási technikákat fejlesztette az extrém időjárási jelenségek gyakorisága és intenzitása változásának előrejelzésére (Goddess, 2005). A MICE szintén az extrémumok változását vizsgálta, azonban inkább a gazdasági szektorban megfigyelhetőekre koncentrált (Hanson et al., 2007).

Az ENSEMBLES projekt 2004 szeptemberétől 2009 decemberéig tartott. A projektet az UK Met Office vezette és 20 ország 66 intézménye vett részt zömében Európából, de a világ más tájairól is voltak intézetek (pl.: USA, Japán és Kína). Célja a kutatók, döntéshozók és a nyilvánosság tájékoztatása a legújabb klímamodellezési és elemzési eszközök felhasználásával. Az ENSEMBLES projekt lényege több, különböző klímamodell („ensembles”) együttes futtatása, amely növeli a pontosságot és az elörejelzések megbízhatóságát. A projekt kimenete tehát jövőbeli előrejelzések sorozata, amelyek különböző jövőbeli stratégiák megalkotására készteti a döntéshozókat. A PRUDENCE projekttől eltérően itt már nem csak a 2071-2100 időszakra koncentráltak, hanem az 1951-2100 közötti időszakra végeztek el tranziens futtatásokat. A projektben $25 \mathrm{~km}$-es felbontású regionális klímamodellek adatait használták fel és valamennyi az A1B szcenáriót alkalmazta. A határfeltételeket 5 különböző GCM adta (van der Linden, Mitchell, 2009). Az EMSEMBLES projekt a korábban említett projekteken kívül a DEMETER (Palmer et $a l .$, 2004), CECILIA (Halenka, 2007) és CLAVIER (Jacob et al., 2008) projektek ered- 
ményeit is felhasználta. A DEMETER projekt célja több modellből álló, együttes előrejelzés végrehajtása volt több kapcsolt globális óceán-légkör modellel. A CECILIA és CLAVIER projektek a közép-kelet-európai térség extrém időjárási körülményeit vizsgálták.

A legújabb RCP szcenáriók alkalmazása a CORDEX (Coordinated Regional Climate Downscaling Experiment) projekt keretében valósult meg, amelyen belül az európai térségre az EURO-CORDEX (Jacob et al., 2014), a mediterrán térségre a Med-CORDEX (Ruti et al., 2016) koncentrált.

\subsection{Városklíma modellezés}

Az előzőekben ismertetett modellek segítségével globális és regionális léptékben kaphatunk képet egy adott térség klímájáról, illetve annak változásáról. A felszín-növénylégkör kölcsönhatások nagy felbontású szimulációja a globális klímamodellek fontos részei. Szemben a GCM-ekben leírt nagy skálájú jelenségekkel, a légkör határréteg, amely élettérünkként szolgál, érzékenyebb a kis skálájú folyamatokra, melyeknek következtében egyedi, lokális klíma alakul ki. Ahhoz, hogy ezeket a helyi hatásokat szimulálni tudjuk, szükséges a modellezés kiterjesztése a mesterséges városi környezetre (Bruse, Fleer 1998).

A felszínborítás megváltozása fontos részét képezi a klímamódosulás folyamatának, ugyanakkor kevésbé számszerüsített (Hougton et al., 2001). A globális és regionális klímamodellek megadják a felszínborítás változásának hatását a klímára, de ezek a vizsgálatok csak a vegetáció típusában történő módosulásokat elemzik. Az urbanizáció folyamatának egy fontos, de ugyanakkor kevésbé vizsgált része az antropogén eredetű felszínborítás változás. A változás hatása tulajdonképpen a legfontosabb és a legérdekesebb azokon a területeken, ahol a népesség döntő része él, ugyanis a városi és nem városi területek eltéröen reagálnak ezekre a változásokra. Ez a hatás a településeken csak akkor becsülhetö, ha a városi területeket is belevesszük a modellezési folyamatba (Oleson et al., 2007).

A város megjelenítése légköri modellekben vagy időjárás elörejelző rendszerekben a felszín energiaegyenlegének megfelelő, valamint a városi hatás és folyamatok kellően pontos figyelembevételével valósulhat meg. Az elörejelzés fejlödésével a modellek rácsfelbontása elérte a néhány km-t, amikor egyes cellák már teljes mértékben városiaknak tekinthetők. Ekkor már adott a lehetőség, hogy a városi lokális klímát előrejelezzék, ugyanakkor felbontásukkal csak a legnagyobb városok modellezhetők, ezért a felszínegyenleg séma légköri modellel történő kapcsolása szükséges (Hidalgo et al., 2008). Ennek segítségével lehetővé válik a hősziget és a város által keltett áramlások szimulálása vagy akár elörejelzése (Souch, Grimmond, 2006).

Az épületszinti felbontással rendelkező modellek esetében, amelyekben egyedi épületformákat írunk le, specifikus folyamatok megadása szükséges. Mivel a számítási kapacitások eleinte korlátozottak voltak, az alkalmazások legtöbbször egy magasabb, azaz lokális szinten történtek több épületre átlagolt modellek alkalmazásával (Masson, 2000). A városi felszín megközelítései közül a leghíresebb Oke (1987) kanyon modellje, amelynek alkalmazásával kezdetben számos esetben éltek (Johnson et al., 1991; Mills, 1993; Arnfield et al., 1998).

A városi területek leírására szolgáló modellek közül a legegyszerübbek az empirikus modellek pl. a NARP-LUMPS (Grimmond, Oke, 2002; Offerle et al., 2003). Ezek a modellek mérési adatokból származtatott statisztikai kapcsolatokon alapulnak és azzal a megközelítéssel élnek, hogy a folyamatok fizikai alapját maguk a mért adatok tartalmazzák. Előnyük, hogy kevés egyenlet megoldását igénylik és alacsony számú bemenő adat 
szükséges. Azonban egy ilyen statisztikai módszer megfelelő alkalmazásához számos méröállomás adata szükséges. Hátránya, hogy mivel mérési adatokat használ, így csak a mérés helyszínével hasonló környezetek körülményeinek leírására alkalmas (Masson, 2006). Erre egy kiváló szegedi példa Balázs et al. (2009) empirikus modellje, amely a hősziget mintázatot adja meg felszínparaméterek alkalmazásával, azonban a módszer csak a Kárpát-medence síkvidéki területein alkalmazható. Külön csoportot alkotnak a városra adaptált vegetációs modellek, amelyek a város módosult, fontosabb felszíni paramétereire koncentrálnak, a városi területek jobb reprezentálása érdekében (Brown, 2000; Masson 2006). A bemutatott módszerek nem a legmegfelelőbbek a klímamodellekben történő alkalmazásra, hiszen a paraméterek globális származtatását igénylik, amelyet fizikailag nehéz interpretálni (Grimmond et al., 1991). A megközelítések nem írják le teljes körüen azokat a folyamatokat, amelyek meghatározzák a város hatását a klímára (Piringer et al., 2002).

Ha a városi hatás modellezése RCM-mel valósul meg, akkor a városi hatások figyelembevételéhez különböző parametrizációk és egy-, vagy többrétegü tetöréteg modell alkalmazása szükséges. Ezeket akkor célszerü alkalmazni, ha városoknak a nagyobb skálájú folyamatokra történő hatását kívánjuk vizsgálni. Az egyrétegü modellek csak egy, a legfelső tetőszint fölötti légréteggel vannak közvetlen kapcsolatban. Azaz, ha egy légköri modellel vannak összekapcsolva, akkor annak alapja a tetőszinten van, így a kanyonok közötti légréteg tulajdonságai nem függnek tőle. Ilyen típusú Masson (2000) városi energiamodellje (Town Energy Budget - TEB), amelynek paraméterei kizárólag az épületformáktól és az alapanyagoktól függenek, azaz alkalmazásához nem szükséges légköri adat. A város reprezentálásának megközelítését egy légköri modellhez kapcsolja, így tulajdonképpen annak felszíni parametrizációjának tekinthető. Mivel mezoskálájú modellekhez használják, ezért a városi karakterisztikákat területi átlagban adja meg, azaz az egyedi épületformákat nem veszi figyelembe és a kanyon megközelítést általánosítja. A kanyont három geometriai paraméterrel írja le (épületek szélessége és magassága, utcák szélessége), ezek a modell egy rácspontjában állandók. A városi energiaegyenleget különböző részekre osztja, így három eltérő energiamérleget használ, külön a tetőkre, utakra és a falakra (Masson, 2000). A TEB modell felhasználása széleskörü pl. Lemonsu, Masson, 2002; Masson et al., 2002; Lemonsu et al., 2004; Hamdi, Masson, 2008. A TEB-hez kívül hasonló egyrétegü modellt dolgozott ki Mills (1997), Kusaka et al. (2001), Harman et al., (2004a, b), Lemonsu et al., 2004, Kusaka, Kimura (2004), Oleson et al. (2007) és Konstantinov et al. (2014).

A SURFEX (Surface Externalisée) egy kiterjesztett föld- és óceánfelszín platform, melynek városi almodelljét a TEB adja (Le Moigne, 2012; Masson et al., 2013). Megalkotásánál egy felszíni, valamint több légköri és hidrológiai modellel kapcsolták. A modell négyféle felszíntípust ír le: természetes, városi, felszíni vizek és óceán. Létrehozásának célja az volt, hogy egyetlen modell széleskörü alkalmazásra legyen képes - az egypontban történő szimulációktól kezdve az időjárás előrejelzéséig vagy akár hosszútávú klíma futtatásokig - a kutatási és fejlesztési erőforrások csökkentése érdekében. Magyarországon Zsebeházi, Szépszó (2015) a SURFEX modellel a léghőmérséklet és a hősziget térbeli karakterisztikáit és időbeli fejlődését vizsgálták Budapesten és Szegeden.

A többrétegü modellek esetében az UCL-ben több réteg helyezkedik el, ezért a légkörrel való kapcsolat már a felszínen megjelenik. Ezekben a modellekben az energiaegyenleg felírása egy valódi, 3 dimenziós városi tetőrétegre történik, így képesek megközelítőleg leírni a tetőrétegben történő folyamatokat. A modellek közül egy komplexebb Martilli et al. (2002) modellje, amely képes kezelni a falak eltérő melegedését. Hasonló, ugyanakkor egyszerübb modelleket dolgoztak ki Vu et al. $(1999,2002)$ és Kondo, Liu (1998), melyek esetében a falak mentén nincs változás, az energiaegyenleg egy adott 
falra vonatkozik, de $V u$ et al. (1999) modelljében az épületek pontosabb figyelembevételére van lehetöség. Kondo et al. (2005) egy egydimenziós többrétegü modellt dolgoztak ki, amely háromdimenziós vizsgálatokra is alkalmazható. A modellben a felszín energiaegyenlege nemcsak a talajra, hanem a tetöre és az épületek falaira négy különböző irányban, valamennyi rétegben megadott. Kikegawa et al. (2003) Vu et al. (1999) modelljét egy egyszerü épületenergia-modellel kapcsolták össze, amely a légkondicionálás használatából származó energiaigényt és antropogén hőt számítja ki. Ezt a kapcsolt modellt további kutatásokban is felhasználták (pl. Kondo, Kikegawa, 2003; Kikegawa et al., 2006; Tokairin et al., 2006; Ohashi et al., 2007; Ihara et al., 2008; Ohashi et al., 2014; Takane et al., 2015; 2017).

Ezek a városi környezet leírása szolgáló modellek a WRF (Weather Research and Forecasting) modellel (Skamarock et al., 2008) összekapcsolhatók (Chen et al., 2011; Kikegawa et al., 2014). A WRF egy nem-hidrosztatikus modell, amelyet eredetileg időjárás-előrejelzésre terveztek, de regionális modellezésre is alkalmazható. A fizikai folyamatokat tekintve számos változó megadható benne. Kifejlesztésénél fontos szempont volt, hogy egy flexibilis, hordozható modellt alkossanak, azaz széles skálán lehet alkalmazni a kutatásoktól az időjárás elörejelzéséig, továbbá a méterestől egészen a több ezer kilométeres térbeli skáláig. Ennek köszönhetően a WRF alkalmas arra, hogy a mezoskálájú és mikroskálájú modellezés összekapcsolása lehetővé váljon egy- vagy többrétegü városi tetőréteg és épületenergia-modell (Salamanca, Martilli, 2010) csatolásával. A modell alkalmazásával történt vizsgálatok száma napjainkban is hatalmas, ami egyúttal mutatja népszerüségét is (pl. Brousse et al., 2016; Göndöcs et al., 2017; Sharma et al., 2017; Takebayashi, Senoo, 2017).

Ha a városi klímamodellek sorát tovább vizsgáljuk, megkülönböztethetünk statikus, illetve dinamikus modelleket, attól függően, hogy hogyan szimulálják az áramlási mezőt. A statikus modellek az áramlási mezőt parametrizálják modell vagy mérési eredmények alapján és emellett a városi felszín leírásához szükséges fizikai folyamatokat tartalmazzák. A statikus modellek sorába tartozik pl. a SOLWEIG (Lindberg et al., 2008), RayMan (Matzarakis et al., 2007; 2010), a TUF-3D (Krayenhoff, Voogt, 2007), a TUF-IOBES (Yaghoobian, Kleissl, 2012), a SkyHelios (Matzarakis, Matuschek, 2010; Matuschek, Matzarakis, 2010) és a SUEWS (Järvi et al., 2011). A dolgozatban is alkalmazott termikus indexeket megadó RayMan modell (2.4. és 3.4. fejezet) bemenő adatigénye kevés és futtatási ideje sem számottevő. Kimenetei pontszerü adatok és az objektumok körüli áramlást nem adja meg, csupán azok árnyékoló hatását.

A dinamikus modellek CFD (computational fluid dynamics) csoportja részletesebb megközelítést ad, ugyanakkor a turbulens áramok szimulációja számításigényes. A legtöbb városi szimulációra használt modellben ennek kiküszöbölésére az áramlási rendszer leírása a Reynolds átlagolt Navier-Stokes (RANS) egyenletrendszer alapján történik. Ezekben a modellekben a turbulenciát parametrizálják és csak az átlagos áramlást jelzik elöre. Ilyen modellek pl. az ENVI-met (Bruse, Fleer, 1998; Bruse, 2004;), a MITRAS (Schlünzen et al.,2003), a MIMO (Ehrhard et al., 2000), UrbClim (De Ridder et al., 2015) és a MUKLIMO_3 (Sievers, 2012, Sievers, 2016).

Az ENVI-met, amely egy háromdimenziós nem-hidrosztatikus modell, a nedvességés hőáramot szimulálja, valamint jól kezeli a tereptárgyak hatását. A modellel mikroskálájú futtatások végezhető kisebb területre, ennek ellenére számítási igénye jelentős. További hátránya, hogy valós időjárási szituációkat nem tudunk megadni, csupán egyszerüsített, idealizált helyzeteket. Alkalmazása a várostervezésben történő kis skálájú beépítés-változásokat vizsgáló esettanulmányokra a legmegfelelőbb. Az ENVI-met-et több szegedi kutatás is alkalmazta, így pl. Égerházi, Gál (2012), Égerházi et al. (2013), Takács et al. (2017) és Kántor et al. (2018). 
A dolgozatban alkalmazott MUKLIMO_3 modell (3.6. fejezet) a városi környezetek léghőmérséklet és légnedvesség mezőjét képes megadni. A modellel valós és idealizált légköri körülmények is szimulálhatók, ahol a helyi felszínhasználati tulajdonságok a hangsúlyosak, különös figyelmet fordítva az épületek és a légkör közötti kölcsönhatásokra. A modellt több kutatás alkalmazta a városon belüli hőterhelés vizsgálatára ( $\check{Z} u$ vela-Aloise et al., 2014; Buchholz, Kossmann, 2015; Žuvela-Aloise et al., 2016; ŽuvelaAloise, 2017; Geletič et al., 2016a; 2018). A városi felszín megadása sokkal egyszerübb és kevésbé korlátozott, mint pl. a WRF esetében, ahol ilyen esetben a várost jellemző paraméterek mellett a felhőzet és a konvekció leírását is változtatni kell a határréteg eltérő sajátosságai miatt.

A RANS modellek hiányossága, hogy a városi tetőréteg turbulens örvényeit nem tudják szimulálni, ezt a LES (large eddy simulation) modellek képesek pótolni. Ezeknek a modelleknek a térbeli és időbeli felbontása nagy, a rácstávolság néhány cm-es nagyságú. Ennek nagy felbontásnak köszönhetően kevés folyamatot kell parametrizálni, de ennek köszönhetően számítási igényük hatalmas. Ilyen modellre példa a DALES (Heus et al., 2010) és a PALM (Maronga et al., 2015; Resler et al., 2017). 


\section{Módszerek}

\subsection{Szeged lokális klímazónáinak meghatározása és területi eloszlásuk}

Szeged lokális klímazónáinak (2.2. fejezet) lehatárolása, illetve térképezése két módszer alkalmazásával is megtörtént. A zónák területi eloszlásának leírása és jellemzése előtt érdemes az egyes térképek elkészítésének módjait ismertetni. Kutatásom során mindkét módszer által elkészített térképet alkalmaztam az adott témakörtől függően, a Lelovics-Gál-módszert eredményét a 4-7. fejezetben, a Bechtel-módszer eredményét pedig a 8 . fejezetben.

\subsubsection{Lelovics-Gál-módszer}

Az egyes lokális klímazónák elhatárolására alkalmazott paraméterek felsorolása már a korábbiakban megtörtént (2.6. táblázat). Az LCZ típusok sajátosságait megadó tíz paraméter közül Szeged valamennyi vizsgált részterületére hét adható meg a rendelkezésre álló adatbázisok alapján (Lelovics et al., 2014). A módszer alkalmazása során az eredeti paraméterek közül kimaradt a magasság/szélesség arány $(\mathrm{H} / \mathrm{W})$, mivel csak szabályos utcahálózat esetén lehetne egyértelmüen kiszámítani, valamint a rendelkezésre álló adatok hiánya miatt a hőátadási tényező és az antropogén hökibocsátás is (Unger et al., 2014a, 2014b).

Az LCZ-k területi eloszlásának meghatározásához az ún. telek-poligonok adták a területi egységeket. Ezek olyan kisebb, szabálytalan alakú területegységek, amelyek lehatárolásának alapja az érintkező épületekből álló épülettömb (Grimmond, Oke, 1999). Ezekre történt a paraméterek átlagának kiszámítása, majd az értékek alapján az egyes poligonok besorolása a különböző LCZ típusokba (3.1a. ábra).

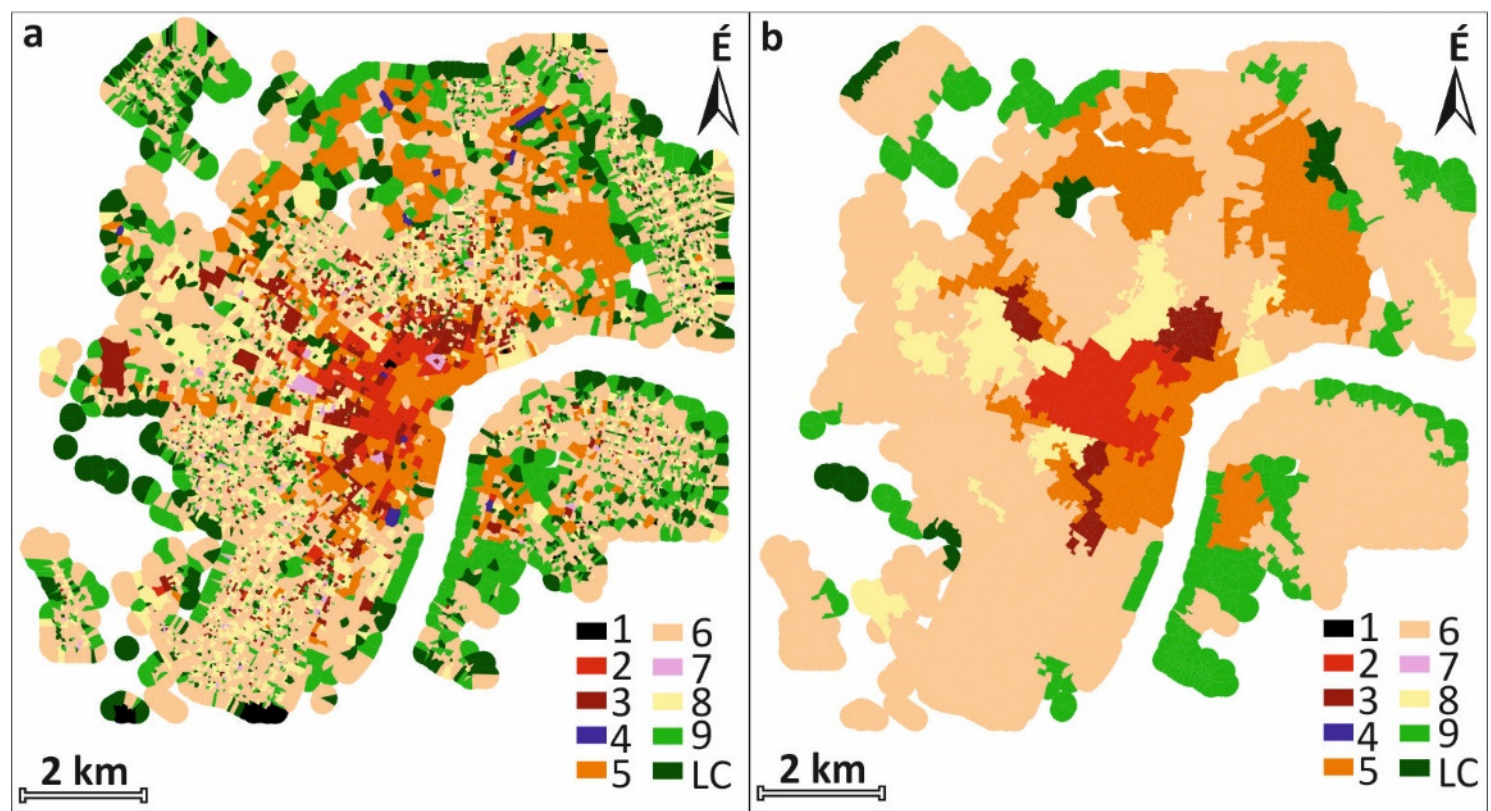

3.1. ábra: A telek-poligonok LCZ osztályba sorolása (a) és összevonása (b) Szegeden (LC: felszínborítással jellemzett típusok (LCZ A-G)) (Unger et al., 2014b; Unger, Gál, 2017)

A módszer alkalmazása során a hangsúly az urbanizált területek elkülönítésén, azaz a beépített jellegü típusok meghatározásán volt. A településszerkezet és az építészeti hagyományok alapján már eleve feltételezhető volt, hogy a következő négy típus nem for- 
dul elö: LCZ 1, 4, 7 és 10. A zónák definíciója miatt szükséges a hasonló vagy ugyanolyan LCZ osztályba sorolt poligonok összevonása, megközelítőleg pár száz métertől néhány kilométerig terjedő zónákba (3.1b. ábra). Jelen esetben a zónák minimum területének mérete, azaz a középpontjuk és határuk távolsága 250 m-ben lett meghatározva.

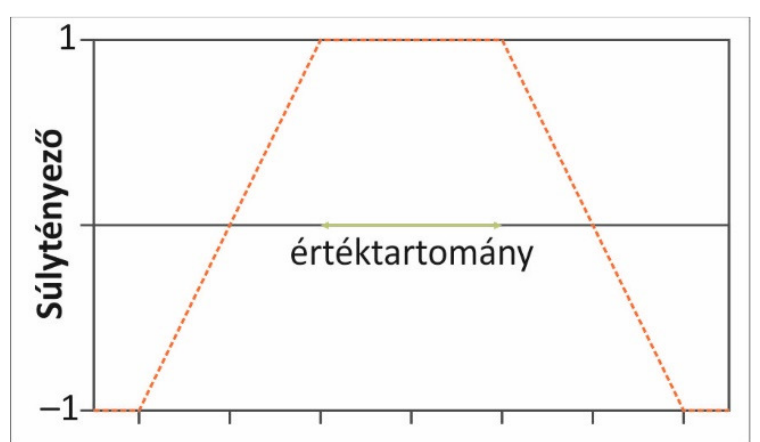

3.2. ábra: A telek-poligonok osztályozásánál alkalmazott súlytényezők megadására alkalmazott függvény vázlata (Unger et al., 2014b; Unger, Gál, 2017)

Részletesen, a megfelelő méretű LCZ-k kialakítása három lépésben történt, amelyből az első a telek-poligonok egyenkénti osztályozása volt. Az alkalmazott paraméterek terület átlagai minden poligon esetében kiszámításra kerültek és különböző súlyokat kaptak. A súlytényező 1-es értéket kapott, ha a poligon átlagértéke a Stewart, Oke (2012) által, az egyes LCZ-kre megadott értéktartományon belül volt. A tartományon kívül eső értékek súlytényezője a 3.2. ábrán bemutatott függvény szerint csökken -1-ig. Ennek a módszernek a segítségével azok a telek-poligonok is a legvalószínübb LCZ osztályba kerülnek, amelyek értékei kis mértékben eltérnek a megadott értéktartományoktól. Az alkalmazott hét paraméter súlytényezőinek összegei alapján a két legvalószínűbb LCZ osztály kerül meghatározásra. Osztályozatlan típust kaptak azok a területek, ahol a súlytényezők összege túl alacsony volt (Lelovics et al., 2014).

A második lépés a poligonok összevonása a legvalószínübb LCZ osztályaik és egymáshoz viszonyított elhelyezkedésük alapján (3.1b. ábra). A szomszédos, azonos LCZ típusú poligonok egyértelmüen összevonásra kerülnek. Ez abban az esetben is megtörténik, ha egy adott poligon LCZ típusa nem egyezik meg szomszédok típusával, de a szomszédok típusa megegyezik. Ha a vizsgált poligon szomszédjainak típusa nem egyezik meg, akkor a vizsgált poligon második típusát figyelembe véve lehet besorolni a szomszédos poligon csoportok valamelyikébe. Végül az osztályozatlan és nem összevont poligonok a szomszédjaik közül leggyakrabban előforduló típust kapják (Lelovics et al., 2014).

A harmadik lépés az egyes LCZ típusokba sorolt, összevont poligonok területi kiterjedésük alapján történő vizsgálata. Ha a poligon csoport középpontjának távolsága a határától meghaladja a $250 \mathrm{~m}$-t, akkor ez a csoport különálló LCZ területnek tekinthető. Amennyiben ez a feltétel nem teljesül, akkor további osztályozás szükséges, amely kétféle módon történhet. Az egyik eset az, amikor különböző LCZ-típusú poligonok összmérete eléri a követelményt, ekkor az így kialakult csoport leggyakoribb osztálya adja meg a csoport LCZ típusát. Ha a mérete nem éri el a megkövetelt minimumot, akkor hozzáadódik ahhoz a szomszédos poligoncsoporthoz, amellyel közös határa a legnagyobb. A módszer utolsó fázisa a zónák határvonalainak generalizálása, amely légifelvételek és helyismeret alapján manuálisan történik (Lelovics et al., 2014). 


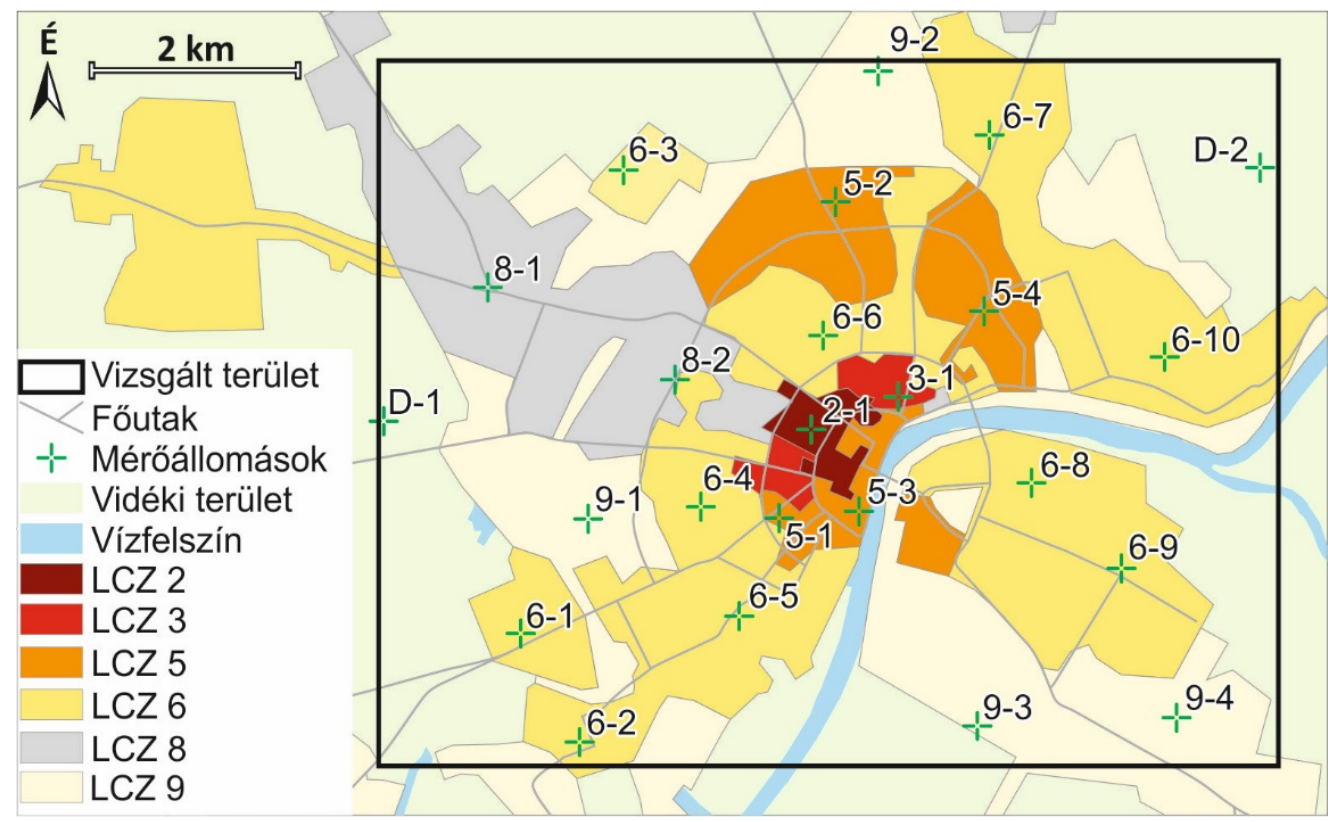

3.3. ábra: Szeged lokális klímazónái a Lelovics-Gál-módszer alapján és a szegedi méróállomáshálózat elemeinek elhelyezkedése (Unger et al., 2014b, c)

A Lelovics-Gál-módszer által kapott térkép alapján Szeged városi területein 6 beépített lokális klímazóna típus található, amelyek a következők: LCZ 2, 3, 5, 6, 8 és 9 (3.3. ábra). A kompakt zónák (LCZ 2 és 3) a központi, míg a nyitott, alacsony (LCZ 6, 8 és 9) zónák a külső területeken helyezkednek el. A kompakt-közepes zóna (LCZ 5) a központi és kintebb fekvő területeken egyaránt megtalálható. A város határának mentén az alig beépített LCZ 9 nagy területi kiterjedésü, itt az urbanizált terület fokozatosan vidékibe (pl.: LCZ B, D) alakul át (Skarbit et al., 2017).

\subsubsection{Bechtel-módszer}

A lokális klímazónák térképezésére más eljárások is ismertek (pl.: Lehnert et al., 2015, Kotharkar, Bagade, 2017; Wang et al., 2017), amelyek közül a Bechtel-módszer (Bechtel et al., 2015) terjedt el leginkább, egyszerüségének köszönhetően. A módszer univerzálisnak tekinthető kevés bemenő adatigénye miatt, azaz valamennyi város esetében könnyen alkalmazható, abban az esetben is, ha nem áll rendelkezésre kiterjedt felszíni adatbázis. Bemenő adatként csupán ingyenesen elérhető (Landsat) müholdképeket igényel, amelyek megközelítőleg 30 méteres felbontása lehetővé teszi a városi léptékben történő térképezést. A módszer alkalmazásához két, szintén ingyenesen elérhető szoftver szükséges, ezek a Google Earth és a SAGA-GIS. Ezek a tulajdonságok segítették a módszer széleskörben történő használatát, amely jól tükröződik abban, hogy a globális LCZ adatbázis létrehozását megcélzó WUDAPT-projekt (Mills et al., 2015) szintén ezt alkalmazza.

A térképezési folyamat első része az ún. tanulóterületek kijelölése a Google Earth szoftverben. Ezek a területek az egyes LCZ-k egy-egy tipikus mintái, amelyeknek kijelöléséhez bizonyos szintü helyismeret szükséges. Második lépésként a SAGA-GIS szoftver Random Forest elnevezésủ osztályozását kell elvégezni, amely a tanulóterületek és a müholdképek alapján elkészülő irányított osztályozási módszer. Ez a folyamat több részből áll, amelyböl az első a müholdképek kivágása a mintaterülettel megegyező nagyságban, valamint felbontásuk átállítása a mozaikosság elkerülésének céljából 100 m-re. Az 
osztályozás rendkívül érzékeny a tanulóterületek kiválasztására, így - amennyiben szükséges - érdemes az eredmények hibáinak alapján újradefiniálni ezeket.

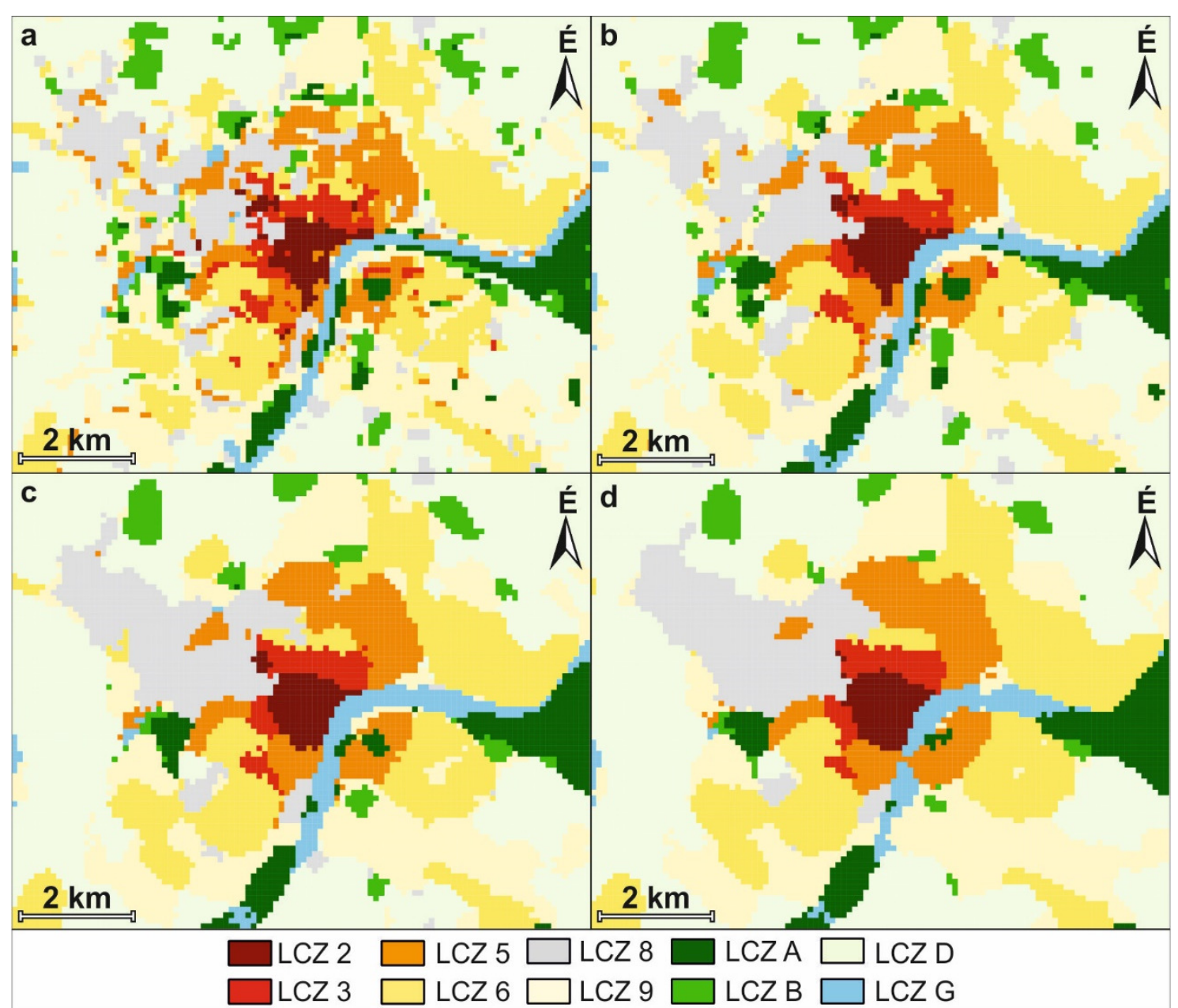

3.4. ábra: Az 1 (a), 2 (b), 3 (c) és 4 (d) pixelméretű szűrők alkalmazásával a Bechtel-módszer alapján készült lokális klímazóna térképek Szegeden (Gál et al., 2015)

Az elöállított LCZ térkép ekkor még nem a végső verzió, ugyanis felbontása 100 mes, azaz nem elegendően nagy ahhoz, hogy elemeit homogén LCZ területként kezeljük. A megfelelő területnagyságot a többségi szürő (majority filter) alkalmazásával érhetjük el. A szürő a vizsgált pixel és az azt körülvevő szomszédos pixelek kategóriáit vizsgálja, és azok közül leggyakoribbat adja meg. A 3.4. ábrán az 1, 2, 3, 4 pixelméretü szürő hatása látható, amely számok azt adják meg, hogy a központi pixeltől számítva hány pixel sugarú körben vagy négyzetben vizsgálódunk. Így például az általunk is alkalmazott négyzet alakú szürő esetében az 1-es méret - a vizsgált pixelt beleszámítva - összesen 9 pixelt jelent, míg a 4-es már 81-et.

Az 3.5. ábra az eredményül kapott LCZ-k eloszlását mutatja be a Szeged területét és környékét tartalmazó vizsgált területen. Az ábra 2 pixelméretü, négyzetes szürő alkalmazásával készült, a 3.4b. ábrához képesti bizonyos eltérés a tanulóterületek többszörös újragondolásának köszönhetö. Az LCZ 2 és 3 típusok a város belső területein helyezkednek el, míg az LCZ 5 a városközpont körül északi, keleti és déli irányokban. A leggyakoribb típusok (LCZ 6 és 9) a külvárosban, míg az ipari-raktárházas területek (LCZ 8) főként a város északnyugati részén jelennek meg. A város körül az LCZ D a jellemző felszínborítottság, ami két kategória (csupasz talaj és alacsony növényzet) összevonása, hiszen a 
mezőgazdasági felhasználás miatt változik az év során. A felhasznált Landsat műholdképek több időpontra vonatkoznak, így e két zóna összevonása egyszerüsíti a tipizálást (Skarbit, Gál, 2016).

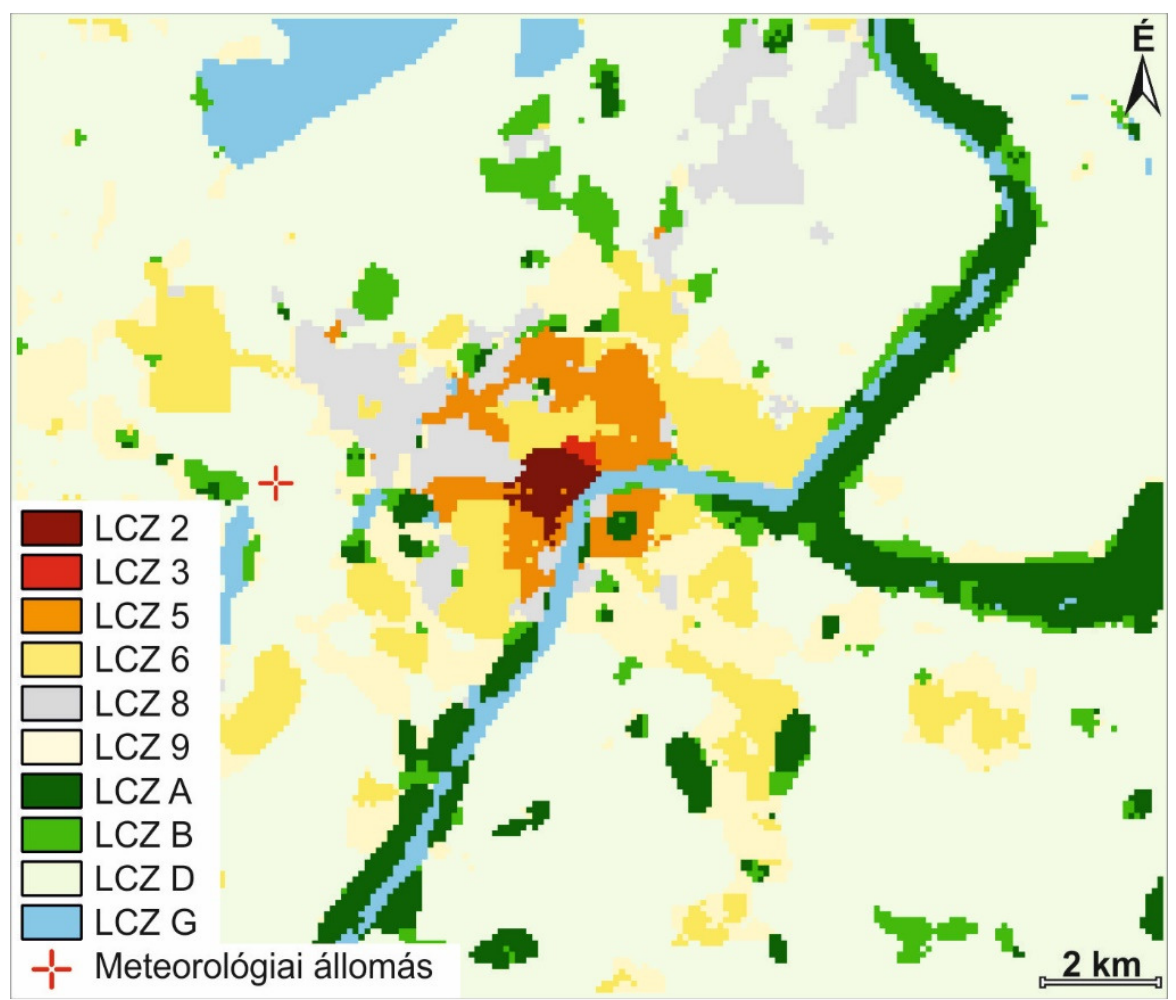

3.5. ábra: Szeged és környezetének végleges lokális klímazóna térképe a Bechtel-módszer alapján (Skarbit, Gál, 2016)

A Bechtel-módszerrel kapott eredmény (3.5. ábra) adta a modellezéshez szükséges felszínhasználati bemeneti adatokat és az e vizsgálatnál számolt LCZ-k szerinti átlagok ez alapján készültek (3.6. fejezet). A módszer jó egyezést ad a Lelovics-Gál-módszerrel készült térképpel (3.3. ábra). Míg az utóbbi a külterületeken nem alkalmazható, addig a Bechtel-módszer ezeken a területekre is ad felszíni információkat. Hátránya, hogy a városi felszínt függőlegesen jellemző paramétereket nem veszi figyelembe, így belterületeken - ahol gyakrabban fordulnak elő magas épületek - az alkalmazása nehézkessé válik. Ha a tanulóterületeket megfelelően választjuk ki, akkor a félreosztályozások valószínüsége jelentősen csökkenthető, azonban még így is tapasztalhatók eltérések. Problémát okozhat a filter használata is, mivel elöfordulhat, hogy egyes különálló területek elegendő kiterjedésük ellenére eltünnek egy másik, nagyobb osztályba sorolás révén.

\subsection{A szegedi mérőállomás-hálózat}

Az URBAN-PATH határmenti régiók fejlesztését célzó EU projekt keretén belül egy 23, illetve egy 27 állmásból álló monitoring hálózat telepítésére került sor Szeged és Novi Sad (Szerbia) városában 2014-ben (URBAN-PATH Project, 2014). Mindkét hálózat folyamatosan regisztrálja a léghőmérséklet $(\mathrm{T})$ és légnedvesség értékeket $(\mathrm{RH})$ és egy online felületen térkép és diagramok formájában meg is jeleníti az adatokat.

A szegedi hálózatnak része az Országos Meteorológiai Szolgálat (OMSZ) által üzemeltetett két állomás is. Külterületi állomása ugyanazon a helyen van, mint a hálózat D1 elnevezésủ egysége (3.3. ábra), aminek célja, hogy egyrészt kontrollszerepet biztosít- 
son, másrészt további adatokat is szolgáltat (globálsugárzás $-\mathrm{G}$, szélsebesség - v). Hasonlóan, a belterületi állomása is biztosít többek között T, RH, G és v adatokat, amely egyben a hálózat 5-1 számú egysége, így ezzel az állomással összesen 24 elemü a hálózat (Unger et al., 2014c, 2015).

A 2.3. fejezetben leírtak alapján egy városi mérőállomás-hálózat telepítése nem tekinthető egyszerü feladatnak a városi felszín összetettsége és változatossága miatt. Az hálózat elemeinek elhelyezése felveti a felszíntípusok és az állomások kapcsolatának problémáját. A fejzetben ismertetett hálózatok telepítése más és más elveken alapult, míg Szegeden az állomások elhelyezése az alapján történt, hogy az előforduló lokális klímazónák elhelyezkedésére és méretére nézve reprezentatívak legyenek (3.3. ábra). Lelovics et al. (2014) alapján az állomások elhelyezésének szempontjai összefoglalóan a következők:

1. minden előforduló LCZ típus képviselve legyen,

2. adott LCZ-ben elhelyezkedő állomások száma arányos legyen a zóna méretével,

3. a mérés helye a zóna szélétől legalább 2-300 m-re legyen,

4. a Balázs et al. (2009) empirikus modellje által generált hősziget mintázatot az állomás-hálózat megfelelően adja vissza,

5. az állomások szükebb környezetének mikroklimatikus viszonyai az adott lokális klímazónára nézve reprezentatívak legyenek,

6. a hely biztonságos, és a mérőeszköz rögzítésére, valamint árammal való ellátására alkalmas legyen.

Az utolsó szempont esetében a város területén a közvilágítás kandeláberei és villanyoszlopok alkalmazása jelentette a megoldást. Ezzel ugyanis adott az áramellátás, és a müszereket $4 \mathrm{~m}$ magasan elhelyezve a rongálásoktól is védve vannak. Ismert, hogy meteorológiai szabványok alapján a hőmérsékletmérés elfogadott magassága $2 \mathrm{~m}$, azonban az utcakanyonban a levegő megfelelő elkeveredésének köszönhetően a 4 m-en mért értékek megfelelően reprezentálják az utcaszinti értékeket (Nakamura, Oke 1988). A külterületi állomások elhelyezése természetesen 2 méteren történt.

A 4. pont megvalósítása egy automatizált módszer kidolgozását igényelte, amely optimalizálja a mérőállomások térbeli elhelyezését. Ennek szükségét az indokolja, hogy egy adott térben elhelyezett pontszerủ adatok elrendezése befolyásolja az adatokból interpolált mező tulajdonságait. A módszerhez szükség volt egy becsült $\Delta T$ mezőre, amelyet Balázs et al. (2009) beépítettségen alapuló statisztikai modellje adott meg. Elsőként a 2. pontnak eleget téve - azaz, hogy az egyes LCZ-k területével arányos legyen az ott elhelyezkedő mérőállomások száma - egy kezdeti hálózat lett megadva, majd az adott mérőhelyek pontjainak modellezett $\Delta \mathrm{T}$ értékeit felhasználva egy új, interpolált mező létrehozása történt. Így az eredeti becsült, és az interpolálás útján kapott mező összehasonlításával megadhatók a geometriai elrendezés hibái. Ennek ismeretében a mérési pontok véletlenszerü mozgatása (1-3. pontok figyelembevételével) addig folytatódott, míg ez hiba el nem érte a minimumot. A folyamat eredménye egy olyan optimális elrendezésű hálózat, amelynek eredményei nem csak pontszerüen, hanem térben is vizsgálhatók, így egyes városrészek vagy az egész város hőmérsékletmódosító hatása elemezhető (Lelovics et al., 2014).

Az állomások pontos helye terepbejárások után lett véglegesen kiválasztva. A fenti szempontokat figyelembe véve 22 állomás került a hat beépített zóna területére (LCZ 2 , 3, 5, 6, 8, 9) és kettő a vidéki jellegű LCZ D-be (D-1 és D-2) (3.3. ábra). Az egyes zónák területén elhelyezett állomások környezetének látképét és légifelvételét a 3.6. és 3.7. ábra, míg az állomások beépített klímazónák szerint elosztását, illetve a zónák területének nagyságát a 3.1. táblázat mutatja be. 




3.6. ábra: Az LCZ 2, 3, 5 és 6 területén elhelyezkedő méröállomások környezetének látképe és légifelvétele (a körök sugara $250 \mathrm{~m}$ ) (Skarbit et al., 2017) 


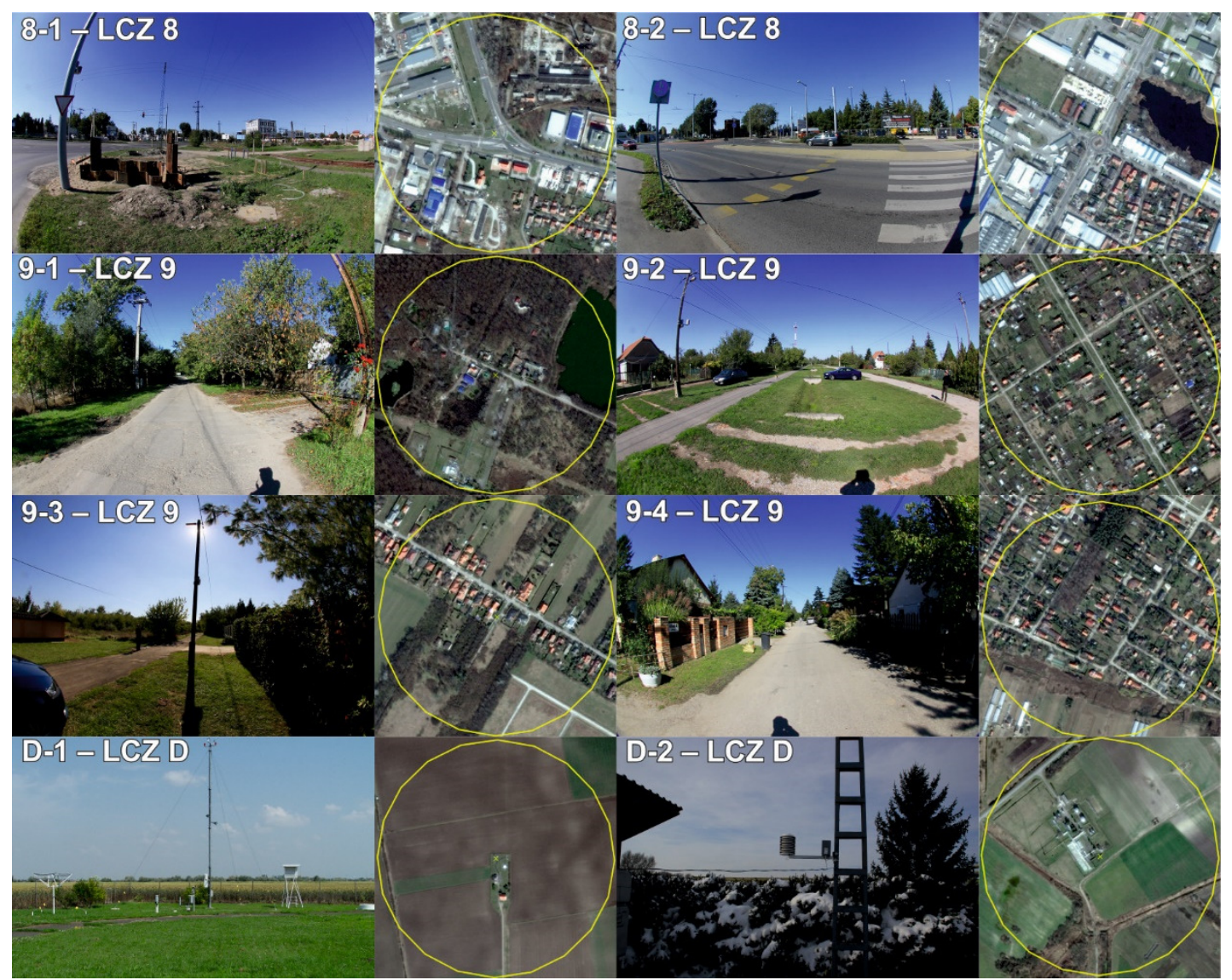

3.7. ábra: Az LCZ 8, 9 és D területén elhelyezkedö mérőállomások környezetének látképe és légifelvétele (a körök sugara $250 \mathrm{~m}$ ) (Skarbit et al., 2017)

3.1. táblázat: A lokális klímazónák területi kiterjedése és állomásaik száma Szegeden

\begin{tabular}{|l|c|c|}
\hline Lokális klímazóna & Terület & Állomások száma \\
\hline LCZ 2 (kompakt-közepes) & $0,63 \mathrm{~km}^{2}$ & 1 \\
\hline LCZ 3 (kompakt-alacsony) & $0,67 \mathrm{~km}^{2}$ & 1 \\
\hline LCZ 5 (nyitott-közepes) & $4,35 \mathrm{~km}^{2}$ & 4 \\
\hline LCZ 6 (nyitott-alacsony) & $19,63 \mathrm{~km}^{2}$ & 10 \\
\hline LCZ 8 (kiterjedt-alacsony) & $5,91 \mathrm{~km}^{2}$ & 2 \\
\hline LCZ 9 (alig beépített) & $15,32 \mathrm{~km}^{2}$ & 4 \\
\hline
\end{tabular}

A szenzorok az oszlopokon egy 60 cm-re kinyúló konzolon helyezkednek el, ellátva egy fehér, üvegszálas anyagból készült sugárzásvédő ernyővel (3.8. ábra). A Sensirion SHT25 típusú szenzorok pontossága $10-60{ }^{\circ} \mathrm{C}$ között $0,2{ }^{\circ} \mathrm{C}$ a hőmérséklet, valamint $10-90 \%$ között $1,8 \%$ a relatív nedvesség esetében. A konzol tövében két doboz található, amelyek közül a felső a vezérlő elektronikát, az adatgyüjtő kártyát, a modemet, az akkumulátort, valamint a töltőt tartalmazza. Az akkumulátorok használatára azért van szükség, mert 8 állomás a közvilágítás kandelábereire lett elhelyezve, ahol az áramellátást a nappali órákban lekapcsolják. Az alsó dobozban elhelyezett kismegszakítóra csak az elektromos hálózathoz való csatlakozás miatt van szükség (Unger et al., 2015).

Az állapothatározók mérése percenként történik és az állomások 10 percenként küldik az adatokat a központi szerverre (Dell PowerEdge T320 tower server) néhány kiegészítő információval (töltöttségi szint, dobozon belüli hőmérséklet, szenzor állapot) együtt. Ha valamilyen oknál fogva a kapcsolat megszakad, az állomás később 
újra megkísérli az adattovábbítást. Amennyiben a töltöttségi szint alacsony, az állomás energiatakarékossági célokból megnöveli továbbítások időközét, vagy akár egy időre fel is függeszti, a mérések zavartalan müködésének biztosítása érdekében.

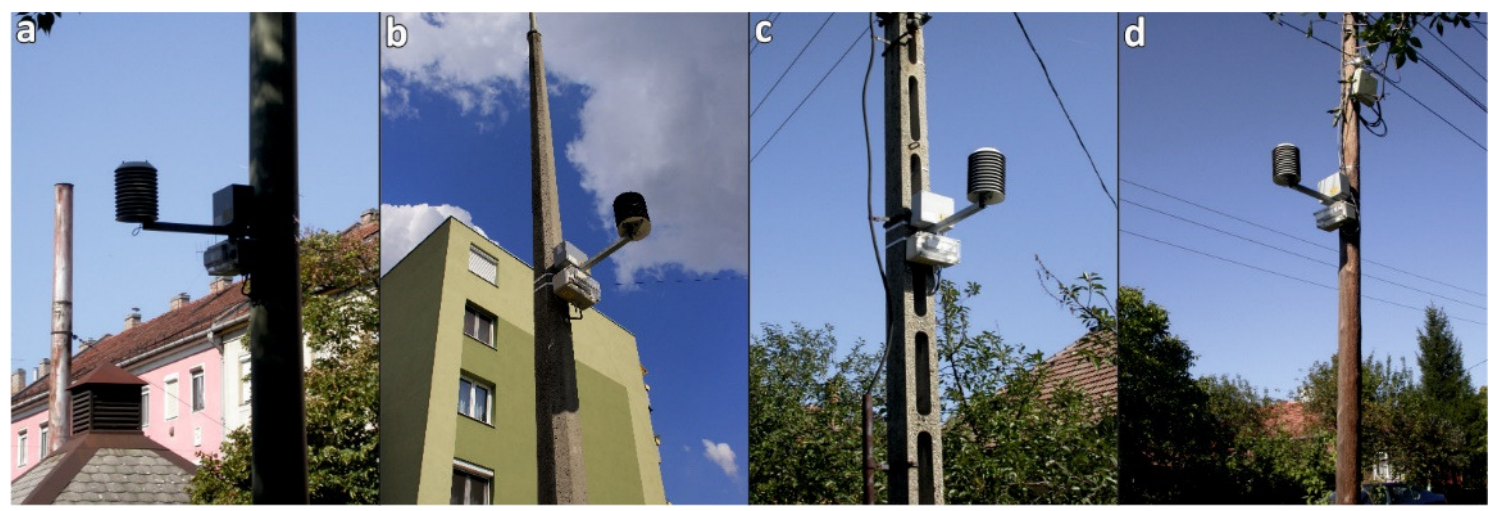

3.8. ábra: Az állomások elhelyezésének néhány példája: (a) acél és (b) beton kandeláberen, illetve (c) beton és (d) fa villanyoszlopon (Unger, Gál, 2017)

\subsection{Felszínhőmérséklet mérések Szegeden}

Vizsgálataimban a lokális klímazónák felszínhőmérsékleti viszonyait is elemzem (6. fejezet), amelyeknek adatait korábbi szegedi mérések biztosították. E mérések (2008.08. 12. és 14.) eredeti célja az egyidejü mobil léghőmérséklet mérésekkel történő összehasonlítás volt, azaz, hogy feltárható legyen a kétféle hőmérséklet közötti kapcsolat (Unger et al., 2010). A mérések végrehajtása egy alacsony költségü, kis formátumú digitális légi felvételező rendszerrel történt. A rendszer alapja egy kisrepülőgépre szerelt FLIR típusú ThermaCAM P65 hőkamera, kiegészítve egy navigációs rendszerrel, valamint egy Thales Mobile Mapper CE típusú GPS/GNSS vevővel. A hőkamera érzékenysége $0,08{ }^{\circ} \mathrm{C}$, spektrális tartománya $7,5 \mu \mathrm{m}$-től $13 \mu \mathrm{m}$-ig terjed. A müszer a hőmérsékletet $-40^{\circ} \mathrm{C}$ és $50{ }^{\circ} \mathrm{C}$ közötti tartományban méri és $320 \times 240$ rácspontból álló képet készít.

A képkészítés sürüségének meghatározása fontos részét képezi a repülési tervnek. A repülés sebessége, magassága és az egymást követő képsorok távolsága adják meg a képek átfedésének mértékét. Ennek az átfedésnek az utómunkálatok megkönnyítése érdekében minimum 20-30\%-nak kell lennie. A repülés 2000 m-en történt $120 \mathrm{kmh}^{-}$ ${ }^{1}$ sebességgel, a megfelelő sürüségü adat előállításához 4 másodpercenként készült egy kép, míg a szomszédos képsorok távolsága 400 m volt (3.9. ábra).

A felmérés után szükséges a már említett utómunkálatok elvégzése. A felvételek elemzésre készített szoftver alkalmazásával a paraméterek ellenőrizhetők és szükség esetén módosíthatók. A repüléssel párhuzamosan végzett terepi mérések (lásd lentebb) eredményeinek használatával pedig kalibrálhatók a rácspontok értékei. A hőképek finomítása az időrendi sorba állításuk után, a repüléssel azonos időben mért hőmérsékleti értékek alapján lehetséges. A feldolgozási folyamat következő lépéseként a repülés közben rögzített GPS útvonalból származtatott koordináta és időadatok kinyerése következik. Ezeket az adatokat a kamera log fájljához kell kapcsolni, amely minden rögzített kép pontos idejét tárolja. A folyamat eredményeképpen valamennyi képközépponthoz tartozó EOV koordináta megállapításra kerül.

Ezt követően a középponti koordináták és a hőmérsékleti képfájlok egymáshoz rendelése történik, így létrehozva egy egyszerü szövegfájlt (ún. world fájlt), ami georeferálja a hőképeket. Ez tulajdonképpen egy durva geometriai korrekció, mely- 
nek pontossága 100-150 m közötti, a repülés közbeni időjárási körülményektől függően. Végül az egyes felvételek összeillesztése egy, a teljes vizsgált területet lefedő, 2,5 m-es területi felbontású fotómozaikot eredményez (Unger et al., 2010).

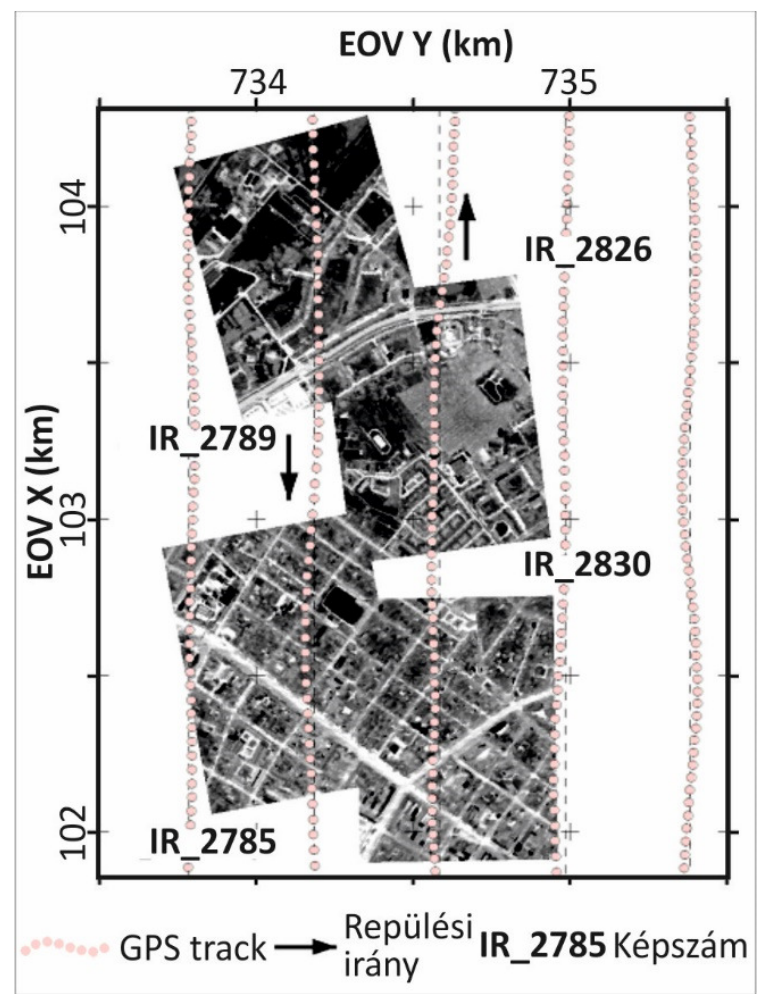

3.9. ábra: Példák a mérés repülési útvonalaira és néhány kalibrált mintakép a vizsgált területről (Unger et al., 2010; Unger, Gál, 2017)

A repülések ideje alatt feltételezhető valamennyi csökkenés a felszínhőmérsékletek $\left(\mathrm{T}_{\text {s.mért }}\right)$ értékeiben. Amennyiben ez az időtől való függés szignifikáns, akkor a rácspontok értékeit korrigálni kell - az általános hülési tendenciának megfelelően - a mérés középidejére. A két éjszaka közül csak a második (aug. 14.) esetében megfigyelt hőmérséklet csökkenés volt szignifikáns. Az időkorrekció során a középidő előtti értékeket időarányosan csökkenteni kell, míg az utána lévő értékeket hasonló módon növelni:

$$
T_{s, m e ́ r t}=-a \cdot t+b \quad T_{s}=T_{s, \text { mért }}+a \cdot t
$$

ahol $a$-trendegyenes meredeksége, $t$ - az idő percben kifejezve, $b$ - a trendegyenes értéke a középidőnél, valamint $T_{s}$ - a korrigált pixelérték.

A hőkamera légifelvételeinek kalibrálásának céljából Szeged két mintaterületén 40 pontban történtek felszínhőmérséklet mérések kézi kontakt-mérővel (DCP D100047 ProTemp szenzor, LogIT DataMeter 1000 adatgyüjtő). A két mintaterület eltérö jellegü (belváros, lakótelep/bevásárlóközpont) volt, továbbá a mérési pontok különböző városi felszíneket reprezentáltak (aszfalt, beton, kő, fü, talaj, víz) (3.10. ábra). Így a hőkamera által mért felszínhőmérsékletek kalibrálása mellett, a felvételek relatív termikus skálája abszolút skálává alakítható. 


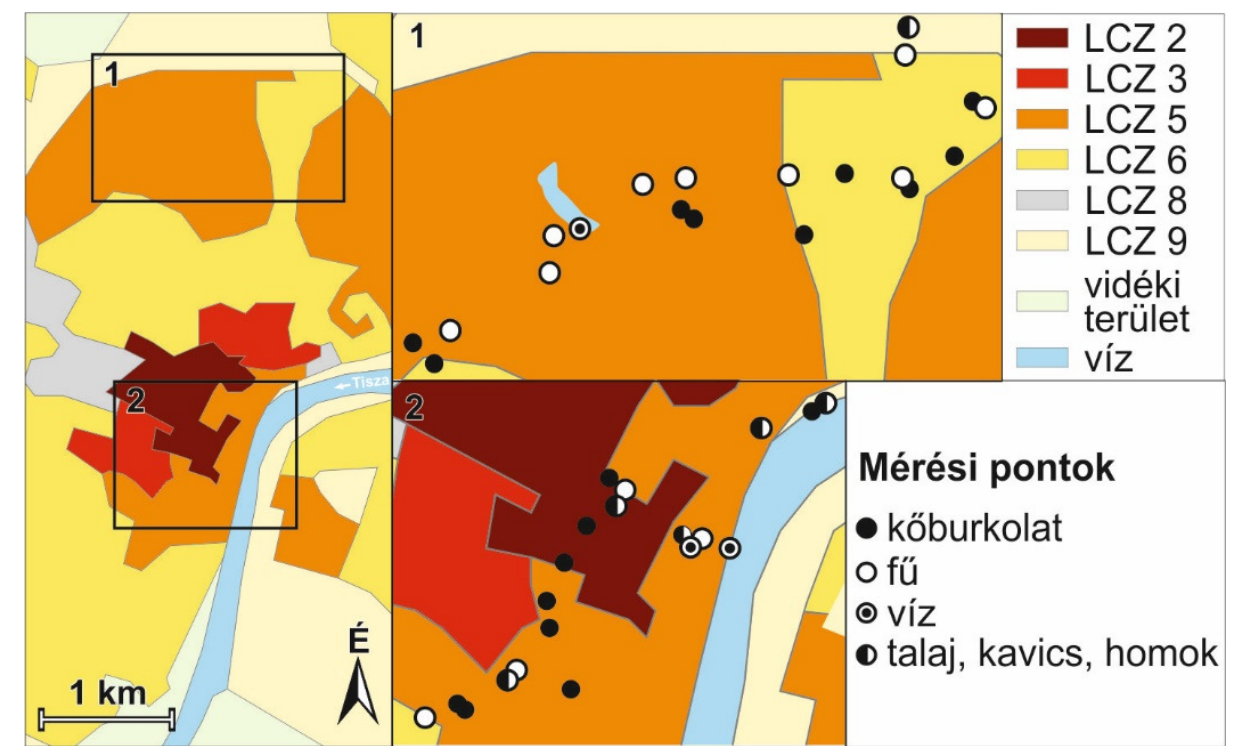

3.10. ábra: A terepi felszínhőmérséklet mérések két mintaterülete és helyszínei (Unger et al., 2010; Unger, Gál, 2017)

Munkám során a felszínhőmérséklet értékeket lokális klímazónánként és a vidéki területre külön vizsgáltam. A területi átlagolás a Lelovics-Gál-módszer alapján kapott LCZ térkép alapján készült, amelyen belül a mérési területet a 3.11. ábra mutatja. A vizsgálat során külön elemzem a teljes területre, illetve csak a földfelszínre jellemző értékeket, az épületek körvonalain belül lévő adatok elhanyagolásával. A fent bemutatott kézi kontakt hőmérővel végzett kalibrációs vizsgálatok azt mutatták, hogy a $10{ }^{\circ} \mathrm{C}$ alatti értékek nem tekinthetők reálisnak, így ezeket nem vettem figyelembe az elemzésnél.

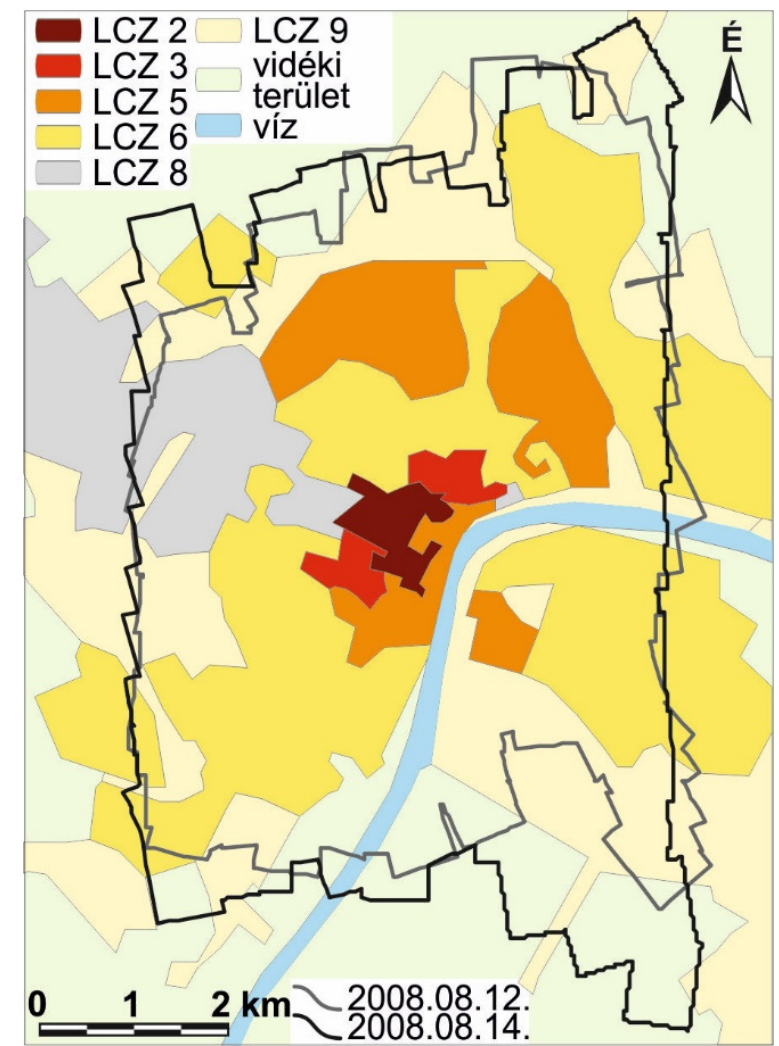

3.11. ábra: A felszínhőmérséklet mérések eredményeként kapott mozaikok határvonala 2008. augusztus 12-én és 14-én a Lelovics-Gál-módszer alapján kapott lokális klímazónákhoz viszonyítva (Skarbit et al., 2015) 


\subsection{A fiziológiailag ekvivalens hőmérséklet és modellezése}

Az emberi hőérzet városon belüli különbségeinek meghatározásához a fiziológiailag ekvivalens hőmérséklet (PET) egy megfelelő mérőszám, mivel tartalmazza minden klimatikus változó együttes hatását. A PET nem más, mint egy standardizált kitalált környezet (ahol az átlagos sugárzási hőmérséklet a léghőmérséklet, a gőznyomás $12 \mathrm{hPa}$, a szélsebesség $0,1 \mathrm{~m} / \mathrm{s}$ ) hömérséklete ${ }^{\circ} \mathrm{C}$-ban, amelyben az emberi test, hogy fenn tudja tartani energiamérlegét, ugyanazokat a fiziológiai válaszokat adja, mint valódi környezetében tenné (Mayer, Höppe, 1987; Höppe, 1999). A PET kiszámolásához elsőként az emberi test termikus körülményeit kell megadni a MEMI modellel (2.4. fejezet) a meteorológiai paraméterek egy adott kombinációja esetén. A kiszámított értékek felhasználásával a modell az emberi testre felírt energiaegyenleg (2.9 egyenlet) alapján adja meg PET értékét. Kiszámításánál a sugárzási hőmérséklet megegyezik a léghőmérséklettel, alig van légmozgás $\left(\mathrm{v}=0,1 \mathrm{~ms}^{-1}\right)$ és a vízgőznyomás $12 \mathrm{hPa}$ (Höppe, 1999). Vizsgálatomban (7. fejezet) a PET 10 perces átlagértékeinek kiszámítása a RayMan modellel történt (Matzarakis et al., 2007, 2010), ami a MEMI-t alkalmazza. A modellt operatív használatra, esettanulmányok elvégzésére tervezték, ezen belül elsősorban a különböző forgatókönyvek szerinti várostervezés vizsgálatára. Tartalmazza az emberi szervezet energiaegyenlegének számítását és a bioklíma becslését termikus indexek használatával. A szoftver olyan bemenő adatokat igényel, mint a léghőmérséklet, légnedvesség, felhőborítottság, környező területek albedója, felszínmagasság és földrajzi fekvés.

A modell az átlagos sugárzási hőmérsékletet (2.4. fejezet) a rövid-és hosszúhullámú sugárzási fluxusok alapján becsüli egyszerü és komplex felszínek esetében is. A $\mathrm{T}_{\mathrm{mrt}}$ és az ahhoz szükséges globálsugárzás és direkt sugárzás kiszámítása Jendritzky et al. (1990), míg a diffúz sugárzás Valko (1966) közelítései alapján adódik. A hosszúhullámú légköri sugárzást az Angstrom-formula adja meg (Falkenberg, Bolz, 1949), a felszíni hömérséklet becslése Oke (1987) alapján történik. Végeredményként a T mrt alapján számít ki három különböző termikus indexet (PET, PMV, SET). A bemenő paraméterek megadására számos lehetőség adott, ezek a topográfiai bemenetek mellett, akár szabadkézi rajzok vagy halszemoptikával készült fotók is lehetnek. Az említett indexek mellett olyan kimeneteket is megad, mint a Nap járása, a városi és vidéki objektumok árnyékolása, a napsütés hossza, valamint a rövid- és hosszúhullámú sugárzási fluxusok különböző időszakokra vett átlagai (Matzarakis et al., 2007, 2010).

Mivel a cél a lokális, és nem a mikro-skálájú termikus viszonyok meghatározása volt, így a mikrokörnyezet hatásaitól független adatokat használtam, azaz az árnyék nélküli körülményeket reprezentáló D-1 állomás (3.3. ábra) zavartalan globálsugárzás értékeit. Logaritmikus profilt és korrekciót alkalmazva a szélsebesség kiszámítása szintén ezen állomás mért értékein alapul, figyelembe véve az egyes városi állomások érdességi paramétereit és az adott terület empirikus redukciós faktorát (részletekért lásd Unger et al., 2015). Így a globálsugárzás és a kiszámított szélsebesség értékek lokális skálán, azaz az egyes LCZ-kre, valamint árnyék nélküli körülményekre/területekre tekinthetök reprezentatívnak. Az előző két állapothatározóval szemben a hőmérséklet és a légnedvesség homogénebb eloszlású, azaz inkább lokális skálán változik, ezért értékeik a városi állomásokról származnak (3.8.3. fejezet).

Munkánkban a PET értékek hőérzeti/hőterhelési kategóriáinak tartományai és elnevezései (pl. „neutrális”) alapvetően Matzarakis, Mayer (1996) munkáján alapulnak, amelyek mérsékelt éghajlati körülmények között élő emberekre vonatkoznak (3.2. táblázat). A skálát széleskörben alkalmazzák mind európai (pl. Gulyás et al., 2006; Knez, Thorsson, 2006; Andrade, Alcoforado, 2008; Müller et al., 2014; Milošević et al., 2016), mind Eu- 
rópán kívüli (pl. Toy, Yilmaz, 2010; Puliafito et al., 2013; Provencal et al., 2016) kutatások esetében. Mivel a klíma térben jelentősen változhat, ezért egy kisebb régió klimatikus jellemzőihez alkalmazkodott népesség hőérzete a fent említett kategóriáktól eltérhet (Kántor et al., 2012). Kántor et al. (2016) több éves szegedi kutatása a magyarországi lakosságra érvényes tartományokat határozta meg, ráadásul évszakokra bontva (3.2. táblázat). Az elemzésem során ezekre az eredményekre támaszkodtam.

3.2. táblázat: A termikus érzékenység $\left(\mathrm{PET}{ }^{\circ} \mathrm{C}\right)$ eredeti kategóriái $\left({ }^{*}\right.$ Matzarakis, Mayer, 1996) és a Magyarországra érvényes kategóriák az egyes évszakok szerint $\left({ }^{* *}\right.$ Kántor et al., 2016)

\begin{tabular}{|c|c|c|c|c|c|c|c|}
\hline \multirow{2}{*}{ időszak } & \multicolumn{7}{|c|}{ termikus érzékenység (PET $\left.{ }^{\circ} \mathbf{C}\right)$} \\
\cline { 2 - 8 } & hideg & húvös & $\begin{array}{c}\text { enyhén } \\
\text { hüvös }\end{array}$ & neutrális & $\begin{array}{c}\text { enyhén } \\
\text { meleg }\end{array}$ & meleg & forró \\
\hline *évi & $4-8$ & $8-13$ & $13-18$ & $18-23$ & $23-29$ & $29-35$ & $35-41$ \\
\hline **tavasz & $-0,8-3,5$ & $3,5-8,4$ & $8,4-14,0$ & $14,0-20,8$ & $20,8-30,7$ & $30,7-$ & \\
\hline **nyár & & $-13,1$ & $13,1-17,3$ & $17,3-22,4$ & $22,4-28,9$ & $28,9-41,4$ & $41,4-$ \\
\hline **ősz & $-2,6$ & $2,6-7,9$ & $7,9-13,9$ & $13,9-21,4$ & $21,4-32,6$ & $32,6-$ & \\
\hline
\end{tabular}

\subsection{Az alkalmazott EURO-CORDEX modellszimulációk és hibakorrekciós eljárás}

Az EURO-CORDEX projekt nagy térbeli felbontású klímaszimulációkat biztosít Európa területére: $50 \mathrm{~km}\left(0,44^{\circ}\right.$, EUR-44) és $12,5 \mathrm{~km}\left(0,11^{\circ}\right.$, EUR-11), így a korábbi projektek (PRUDENCE, ENSEMBLES) eredményeinél részletesebb felbontással rendelkezik (Jacob et al., 2014). Ezek a szimulációk már az új RCP szcenáriókat alkalmazzák (2.5.1. fejezet). A projektben 26 modellező szervezet vett részt 11 különböző regionális klímamodell alkalmazásával. Az EURO-CORDEX domain-je az Európai Unió valamennyi országát magában foglalja. A szimulációk kimeneteit összehasonlítva az ENSEMBLES projekt eredményeivel, a hőmérséklet- és csapadékváltozás területi eloszlásának hasonlósága vehető észre. Ugyanakkor a nagy felbontásnak köszönhetően az intenzív csapadékhullással járó események területi eloszlásának változása egyértelmüen kimutatható, ami a meghatározó fizikai folyamatok jobb leírásának köszönhető.

3.3. táblázat: A modellezési vizsgálatban alkalmazott EURO-CODEX szimulációk és az általuk alkalmazott szcenáriók

\begin{tabular}{|c|c|c|c|}
\hline Meghajtó GCM & RCM & Intézet & Szcenáriók \\
\hline $\begin{array}{c}\text { CNRM_CM5 } \\
\text { (Voldoire et al., 2013) }\end{array}$ & $\begin{array}{c}\text { RCA4 } \\
\text { (Kupiainen et al., 2011) }\end{array}$ & $\mathrm{SMHI}^{1}$ & \multirow{6}{*}{ RCP4.5, RCP8.5 } \\
\hline $\begin{array}{c}\text { EC-EARTH } \\
(H a z e l e g e r \text { et }\end{array}$ & $\begin{array}{c}\text { RACMO22E } \\
\text { (van Meijgaard et al., 2012) }\end{array}$ & $\mathrm{KNMI}^{2}$ & \\
\hline & $\begin{array}{c}\text { HIRHAM } \\
\text { (Christensen et al., 1998) }\end{array}$ & $\mathrm{DMI}^{3}$ & \\
\hline $\begin{array}{c}\text { IPSL-CM5A-MR } \\
\text { (Dufresne et al., 2013) }\end{array}$ & \multirow{3}{*}{$\begin{array}{c}\text { RCA4 } \\
\text { (Kupiainen et al., 2011) }\end{array}$} & \multirow{3}{*}{$\mathrm{SMHI}^{1}$} & \\
\hline $\begin{array}{c}\text { HadGEM2-ES } \\
\text { (Jones et al., 2011) }\end{array}$ & & & \\
\hline $\begin{array}{c}\text { MPI-ESM-LR } \\
\text { (Giorgetta et al., 2013) }\end{array}$ & & & \\
\hline
\end{tabular}

${ }^{1}$ Swedish Meteorological and Hydrological Institute (Svéd Meteorológiai és Hidrológiai Intézet)

${ }^{2}$ Koninklijk Nederlands Meteorologisch Instituut (Holland Királyi Meteorológiai Szolgálat)

${ }^{3}$ Danmarks Meteorologiske Institut (Dán Meteorológiai Intézet) 
A 21. századra vonatkozó vizsgálataimban az EURO-CORDEX $0,11^{\circ}$ felbontású léghőmérséklet, relatív nedvesség, szélsebesség és szélirány adatait használtam fel (8. fejezet). Az alkalmazott szimulációk kiválasztása az alapján történt, hogy ezek a változók a kimenetek között rendelkezésre álljanak. Ennek a feltételnek 14 tett eleget, így 5 különböző GCM és 3 RCM eredményeit használtam fel (3.3. táblázat). A szimulációk közül hét-hét az RCP4.5 és RCP8.5 szcenáriók alkalmazásával futott, a végső eredmény e futtatások eredményének az átlaga.

A klímamodellek önmagukban nem nyújtanak tökéletes végeredményt, mivel komplex kölcsönhatásokat és folyamatokat írnak le, aminek következtében eredményeik szisztematikus hibákkal terheltek. Ezeknek a hibáknak a minimalizálása érdekében hibakorrekciós eljárást szükséges elvégezni. Számos ilyen eljárás ismert, amelyeknek egyike a jelen vizsgálatban alkalmazott bias hibakorrekció (Ehret et al., 2012). A módszer alapja az a feltételezés, hogy két adatsor statisztikailag azonosnak tekinthető, ha sürüség- és eloszlásfüggvényeik megegyeznek (Formayer, Haas, 2009). Így, egy modellezett adatsort statisztikai tulajdonságai alapján úgy tudunk korrigálni, ha elérjük, hogy eloszlásfüggvénye a mérési eredményekével azonos legyen. A korrigálás során azonos időszakra vonatkozó mérési és modellezett eredmények eloszlásfüggvényét korrekciós faktorokkal egymáshoz illesztjük és azzal a feltételezéssel élünk, hogy ez a hiba időben állandó marad. A faktorok kiszámítása a hőmérséklet esetében a percentilisek különbsége alapján történik. A vizsgálatban az 1971-2000 időszakot tekintettem referencia időszaknak, amelyre kiszámítottam az 1\%-os percentiliseket és ezek eltérését a mérési és modellezett adatok között. Emellett a hőmérsékleti értékek magassági korrekciója is megtörtént, melynek során a város és az egyes rácspontok magasságának eltérését kiszámítva, figyelembe vettem a hőmérséklet magassági szerint csökkenését egy megközelítő, $0,65^{\circ} \mathrm{C} / 100 \mathrm{~m}$-es értékkel. Végezetül a relatív nedvesség adatok korrigált hőmérsékleti értékek szerinti átszámítása is szükséges volt.

\subsection{A MUKLIMO_3 modell}

Szeged városklímájának modellezésénél (8. fejezet) a MUKLIMO_3 modellt alkalmaztam, amelyet a Német Időjárási Szolgálat (Deutscher Wetterdienst) fejlesztett ki mikro- és lokális skálájú városklíma-vizsgálatokhoz és várostervezési célokra (Sievers, 2012, Sievers, 2014).

A nem-hidrosztatikus modell a léghőmérséklet és légnedvesség prognosztikai egyenleteit tartalmazza, kiegészítve a talaj hö- és nedvességegyenlegével (Sievers et al., 1983), valamint egy komplex vegetációs modellel (Siebert et al., 1992). A légkör és a vegetáció közötti kölcsönhatásokat egy 3 rétegü, míg a talaj és a légkör közöttieket egy 15 rétegü részmodell szimulálja. Adott rácspontban a légkör és az épületek közötti kölcsönhatások figyelembevételéhez az épületek struktúrájának leírása három statisztikai paraméterrel történik, amelyek az épületsürüség, a falfelület és az épületek rácsponton belüli átlagmagassága. A rövidhullámú sugárzás parametrizációja Sievers, Früh (2012), míg a hosszúhullámú sugárzás leírása Möller (1954) alapján történik, ahol a felhők hatásának figyelembevételét Zdunkowski et al. (1975) megközelítése adja. Az épületek körüli áramlás Gross (1989) feltételezése szerint történik, amely ezt egy porózus közegen belüli gáz vagy folyadék áramlásához hasonlítja. Az épületek áramlásmódosítása mellett a modell figyelembe veszi az épületek felszínének súrlódási hatását és a körülöttük kialakuló turbulenciát (Früh et al., 2011a). A modell kimenetei a léghőmérséklet, légnedvesség és a szélmező egy 3 dimenziós rácson, továbbá egyéb stacionárius paraméterek, mint pl. égboltláthatóság, levélfelületi index, kiszorítási rétegvastagság, porozitás. Fontos megjegyezni, hogy felhö- és csapadékképződést nem tartalmaz, így alkalmazása a csapadék 
nélküli napokra korlátozódik. A horizontális felbontás az alkalmazástól függően 20 és $500 \mathrm{~m}$ között változhat, míg a vertikális (10 és $100 \mathrm{~m}$ között) általában nagyobb a felszín közelében vagy olyan magasságokban, ami a vizsgálat szempontjából fontos. Kezdeti feltételként egy referenciaállomásról származó egydimenziós hőmérséklet, relatív nedvesség és szélsebesség profilok megadása szükséges, ami jelen vizsgálatban az OMSZ szegedi külterületi állomásáról (D-1, 3.3. ábra) származott.

A modell domain leírásához több, különböző bemeneti fájl megadása lehetséges. A MUKLIMO_3 futtatása történhet ún. meghatározott és nem-meghatározott épületekkel, amelyek különböző bemeneti adatokat igényelnek (Früh et al., 2011a). A nem-meghatározott épületekkel történő modellezés a gyakoribb eset, mivel számítási igénye kisebb. Ekkor három input fájl szükséges: rácspontonként a felszínhasználati osztály és a domborzat magassága, valamint egy táblázat, ami leírja az egyes épület- és növényosztályok tulajdonságait. Meghatározott épületek esetében az épületek pontos megadása szükséges rácspontonként vagy több rácsponton belül. Ekkor a nem-meghatározott modellfuttatás bemeneti fájljai mellett szükség van az épületeket és utcákat megadó fájlokra is. A továbbiakban a nem-meghatározott modellezéshez szükséges bemeneti fájlok felépítését ismertetem.

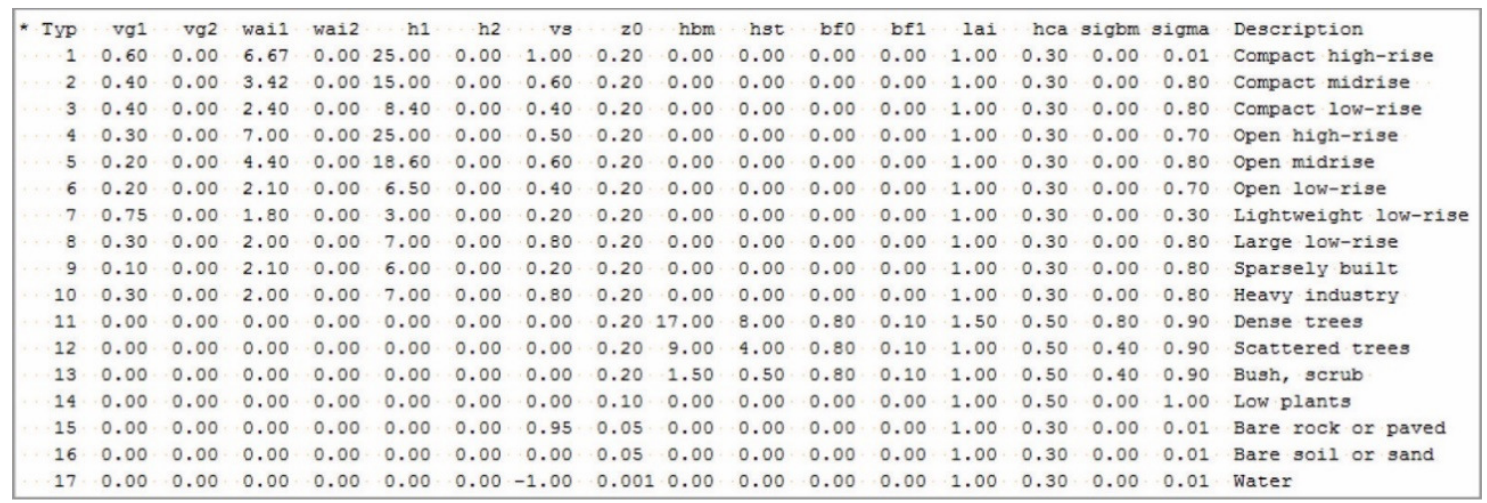

3.12. ábra: A felszínhasználati táblázat formája a lokális klímazónák alkalmazásával

A felszínhasználati táblázat mindegyik általunk meghatározott felszínhasználati osztályra akár 26 fizikai paramétert is tartalmazhat, és osztályonként két épülettípus jellemzői adhatók meg (3.12. ábra). Ezek a paraméterek a következők (zárójelben a fájlban szereplő rövidítésük):

- azonosító szám (Typ)

- első és második épülettípus hányada a rácsponton belül (vg1, vg2)

- $\quad$ első és második épülettípus falfelület indexe (wai1, wai2)

- első és második épülettípus átlagmagassága (h1, h2)

- vízzáró felszín aránya az épületek között (vs)

- kiszorítási rétegvastagság (z0)

- famagasság, törzsmagasság (hbm, hst)

- levélfelület-sürüség a törzsnél és a csúcsnál (bf0, bf1)

- levélfelületi index (lai)

- vegetáció magassága a növényállomány rétegében (hca)

- fa- és vegetáció-borítottság (sigbm, sigma)

- zöldtető aránya (grant)

- falak és tetők albedója (albw, albd)

- vízzáró felszínek albedója a növényállomány rétegében (albvs)

- falak és tetők hővezetése (kwand, kdach)

- falak és tetők hőkapacitása (cwand, cdach) 
- földhasználati osztály leírása vagy neve (Description)

A grant, albw, albd, albvs, kwand, kdach, cwand és cdach változók értékeit csak épületeket tartalmazó osztályok esetében kell megadni, de akár el is hagyhatók. A táblázatban minden sor egy felszínhasználati osztályt képvisel, emellett fejléc és komment sorokat is megadhatunk, amelyek *-gal kezdődnek.

A felszínhasználati fájl x és y irányokban minden rácspontra tartalmazza az adott cella felszínhasználati azonosító számát, ami az előző táblázat „Type” értéke. A mező fölött lehet egy tetszőlegesen hosszú fejléc, ami *-gal kezdődik és ** jelöléssel ér véget. A 3.13. ábrán látható felszínhasználati fájl a szegedi mintaterület egy részletét mutatja be. Fejlécében az oszlopok és sorok száma (ncols és nrows), a bal alsó rácspont koordinátái (xllcorner és yllcorner), a rácstávolság ( $\mathrm{dx}$ és dy), az elforgatás (rotation) és az adathiányt jelölő érték (NODATA_value) szerepel.

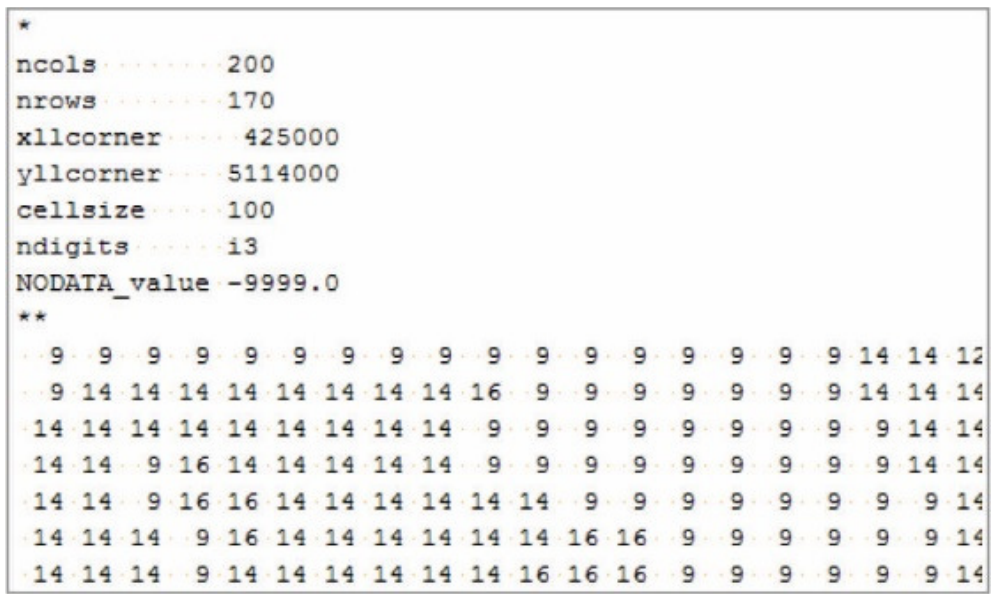

3.13. ábra: A szegedi mintaterület felszínhasználati fájljának egy részlete

A domborzat fájl formátuma az előzőhöz hasonló (3.14 ábra), azaz minden rácspontra megadja a felszín magasságát méterben kifejezve. Hasonlóan az előző fájlhoz, adhatunk tetszőleges hosszúságú fejlécet a , " és , "*” szimbólumokkal határolva. Komplex domborzat esetén numerikus instabilitások léphetnek föl a domain határán, amely probléma további rácspontokkal kibővített modell domain használatával kezelhetö.

3.14. ábra: A szegedi mintaterület domborzati fájljának egy részlete

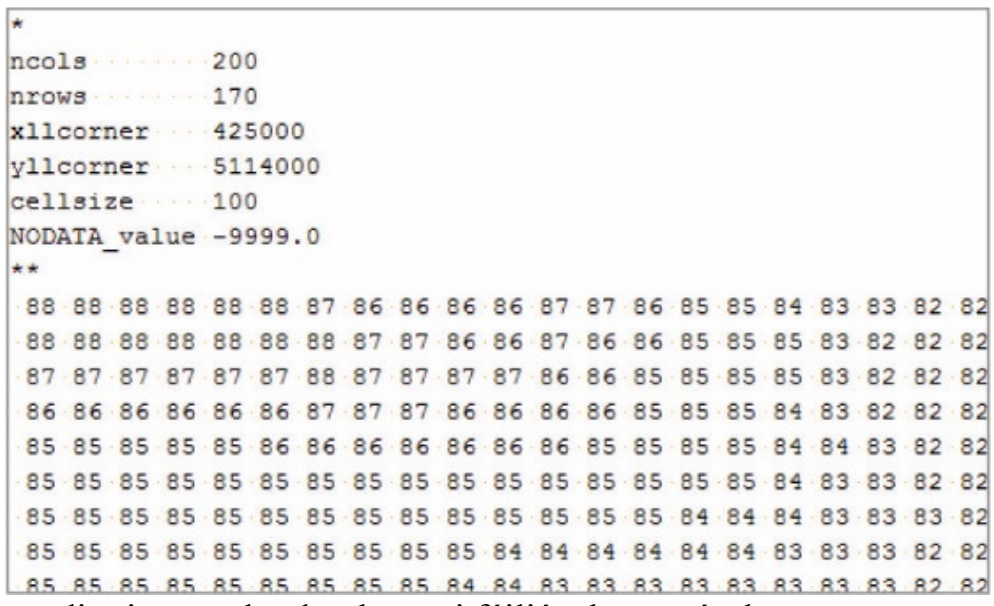

A szegedi vizsgálat során a MUKLIMO_3 modellt horizontálisan ekvidisztáns rácshálózaton futtattam 100 m-es felbontással, a mintaterületet $200 \times 170$ rácspont alkotta 
(3.13. és 3.14. ábra). A vertikális felbontás 10 és $100 \mathrm{~m}$ között változott, a felszín közelében nagyobb felbontást alkalmazva. A felszínhasználat kategóriáit a lokális klímazóna rendszer alapján különítettem el (2.2 fejezet), a paramétereket az adott osztály jellemzői alapján adtam meg (3.12. ábra). A modellhez szükséges felszínparaméterek - melyeket a felszínhasználati táblázat tartalmaz - LCZ típusok szerinti értékeit irodalmi adatok (Stewart, Oke, 2012) és korábbi szegedi vizsgálatokból származó felszínadatok alapján határoztam meg. A felszínhasználati fájlhoz szükséges lokális klímazóna térképezés a Bechtel-módszeren alapult (Bechtel et al., 2015, 3.2.2. fejezet). A domborzati fájl az EOTR (Egységes Országos Térképrendszer) 1:10000 méretarányú térképeinek szintvonalai alapján készült.

\subsection{A cuboid módszer és az alkalmazott klímaindexek}

A beépített területek felszínközeli mikroskálájú folyamatainak modellezése klimatológiai időskálán (30 év vagy több) jelentős számítási kapacitást igényel. A cuboid módszert, ami egy dinamikai-statisztikai leskálázási technika, ennek elkerülésére fejlesztették ki (Früh et al., 2011a). Lényege, hogy trilineáris interpolációs sémát alkalmazva a hosszú idejü regionális klímaszimulációk vagy megfigyelések lokális, illetve mikroskálájú szimulációkkal kombinálhatók. Azzal a feltételezéssel él, hogy azok a regionális légköri viszonyok, amelyekben a városi höterhelés kialakulhat, megadhatók három meteorológiai állapothatározó felszínközeli értékével (3.15. ábra). Ezek az állapothatározók a léghömérséklet $(\mathrm{T})$, relatív nedvesség $(\mathrm{RH})$ és szélsebesség $(\mathrm{v})$, amelyek a cuboid három dimenzióját képviselik (Früh et al., 2011a). Közöttük lineáris kapcsolat feltételezésével rendel értéket az egyes pontokhoz $\left(\mathrm{C}_{\mathrm{i}}\right)$. A cuboid határait (azaz T, RH és v minimum és maximum értékeit) úgy kell meghatározni, hogy valamennyi, a hőterhelés kialakulásának szempontjából kedvező regionális időjárási helyzetet magában foglalja.

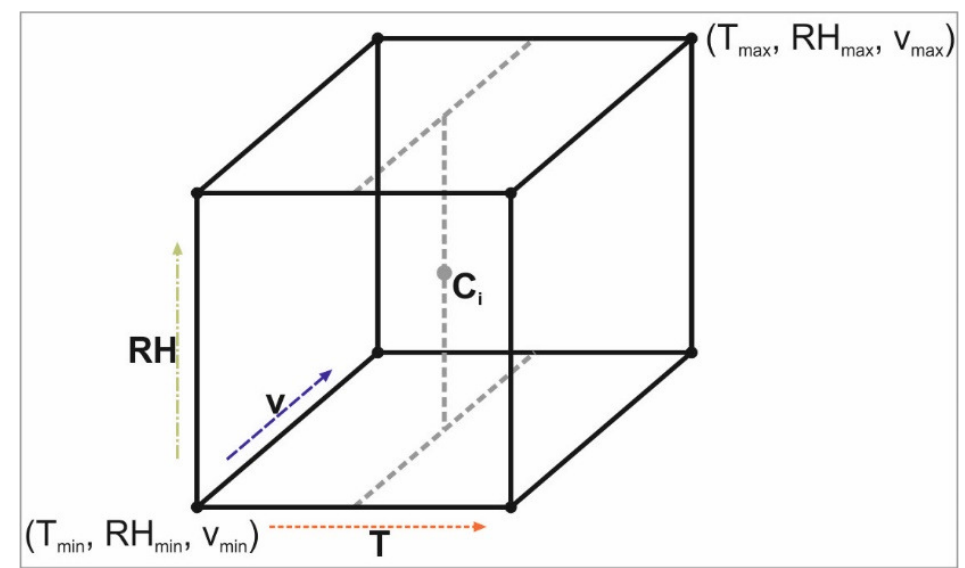

3.15. ábra: A cuboid módszer sémája Früh et al. (2011a) alapján

A MUKLIMO_3 modellel ezeket a sarkokat jellemző helyzeteket szimuláltam két uralkodó szélirányra (északnyugat és északkelet), ami összesen 16 futtatást jelent. A cuboid bemenő adatai ezen szimulációk mellett a vizsgálni kívánt időszak napi adatsora (modellezett vagy mért), amelynek T, RH, v és szélirány adatokat kell tartalmaznia. A módszer kimeneteként különböző klímaindexek (3.4. táblázat) hosszabb időszakra (több évre, évtizedre) számított átlagának a MUKLIMO_3 modellével megegyező horizontális felbontású értékeit kapjuk meg. Fontos megjegyezni, hogy a cuboid módszerben megadott klímaindexek definíciói kis mértékben eltérnek az eddig ismert, más irodalmakban megtalálható értékektől (Unger, Sümeghy, 2002). 
3.4. táblázat: A cuboid kimeneteiként szolgáló klímaindexek és definíciójuk (Früh et al., 2011b)

\begin{tabular}{|c|c|}
\hline Klímaindex & Definíció \\
\hline nyári nap & $\mathrm{T}_{\max } \geq 25^{\circ} \mathrm{C}$ \\
\hline höségnap & $\mathrm{T}_{\max } \geq 30^{\circ} \mathrm{C}$ \\
\hline sörkerti nap & $\mathrm{T}_{20 \mathrm{~h}^{*}} \geq 20^{\circ} \mathrm{C}$ \\
\hline nyári este & $\mathrm{T}_{22 \mathrm{~h}^{*}} \geq 20^{\circ} \mathrm{C}$ \\
\hline meleg éjszaka & $\mathrm{T}_{\min } \geq 17^{\circ} \mathrm{C}$ \\
\hline trópusi éjszaka & $\mathrm{T}_{\min } \geq 20^{\circ} \mathrm{C}$ \\
\hline
\end{tabular}

*Közép-európai nyári idő

\subsection{A vizsgált időszakok és felhasznált adatok}

\subsubsection{A léghömérséklet vizsgálata}

Az állomáshálózat adatainak első feldolgozásánál a vizsgált időszak a müködésének első évének teljes négy évszakot lefedő periódusa volt, azaz 2014.06.01-2015.05.31. (Gál et al., 2016; Skarbit et al., 2017) (4. és 5. fejezet). A vizsgálat az egyéves időszak 10 perces hőmérséklet átlagait és az OMSZ állomás (D-1, 3.3. ábra) felhőzet és szél adatait használta fel. A horizontális hőmérsékleti mező térbeli interpolációjánál valamennyi állomás adatát felhasználtam. Az interpoláció Kriging módszerrel történt egy lineáris variogram modell alkalmazásával, melynek végső felbontása $100 \mathrm{~m}$ volt. Az elemzések során a napnyugta körüli és éjszakai órákra került a hangsúly, mivel a város és vidék közötti, illetve a városon belüli felszínközeli léghőmérséklet különbségek ekkor a legeröteljesebbek (Oke, 1987).

A vizsgálat három lépésben történt, ezek közül az első az egyéves időszak minden napját tartalmazta, tekintet nélkül az időjárási körülményekre. Második lépésként az ún. ideális időjárási körülményekkel rendelkező napok kerültek fókuszba, ugyanis ezek a feltételek segítik a város termikus hatásának kimutatását. Az ideális napok kiválasztása az Oke (1998) által definiált $\Phi_{w}$ időjárási faktor alkalmazásával történt, amelynek kiszámítása a következö:

$$
\Phi_{w}=v^{-\frac{1}{2}} \cdot\left(1-k n^{2}\right)
$$

ahol v - szélsebesség $\left(\mathrm{ms}^{-1}\right), k$ - a Bolz-féle korrekciós faktor és $n$ - a felhőborítottság tizedekben. A $\Phi_{w}$ azt számszerüsíti, hogy a napközben fennálló egyes felhőzeti és szélsebességi viszonyok hogyan befolyásolják az éjszakai lehülés mértékét. A faktor 0 és 1 között változik, ahol a nagyobb érték jelenti a lehülés számára kedvezőbb körülményt. A $\Phi_{w}$ kiszámítása óránként történt a meteorológiai szolgálat SYNOP távirataiban megadott adatok alapján és adott nap napkeltéjétől következő nap napkeltéjéig átlagolva kaptuk meg a napi értéket. Az ideális nap feltétele a $\Phi_{w}>0,7$ reláció teljesülése (Stewart et al., 2014), illetve a csapadékmentesség volt, amely feltételeknek 32 nap tett eleget az egy éves időszakban. Harmadik esetben egy kiválasztott ideális nap (2014.08.29.) éjszakáját vizsgáltuk, ebben az esetben a $\Phi_{w}$ napi értéke 0,9 volt, azaz a hösziget kialakulásához különösen kedvező időjárási körülmények uralkodtak.

A lokális klímazónák termikus eltéréseinek vizsgálatánál szükséges volt néhány állomás elhanyagolása. A 8-2 állomás esetében ez a téli időszakra eső jelentős adathiánynak volt köszönhető, amelynek eredményeként az állomás átlaghőmérséklete $4-5{ }^{\circ} \mathrm{C}$-kal magasabb volt a többi állomás értékénél. A 6-6, 9-1 és 9-3 állomások esetében a problémát 
a területi reprezentativitásuk hiánya okozta, ugyanis a szenzorok mikroskálájú környezetei nem adják vissza a lokális skála viszonyait, így a mért hőmérsékleti adatok nem jellemezték megfelelően az LCZ típusukat.

Megjegyzendő, hogy a D-1 állomás egyéves hőmérséklet értékeit összehasonlítva az 1981-2010 normál időszak értékeivel, az évi átlaghőmérséklet $1^{\circ} \mathrm{C}$-kal magasabbnak bizonyult, mint a 30 éves átlag. Ez elsődlegesen a melegebb télnek köszönhető $\left(+2,4^{\circ} \mathrm{C}\right)$, de az ösz és a tavasz is enyhébb (rendre $+1,5^{\circ} \mathrm{C}$ és $0,5^{\circ} \mathrm{C}$ ), a nyár pedig kissé hüvösebb volt $\left(-0,3^{\circ} \mathrm{C}\right)$ a referencia időszakhoz képest.

\subsubsection{A felszínhőmérséklet vizsgálata}

A szegedi földi és légi bázisú felszínhőmérséklet mérések 2008. augusztus 12-én és 14-én zajlottak (6. fejezet). A légi mérések a napnyugta utáni kb. 2 órás időszakba estek, mivel ekkor a rövidhullámú direkt sugárzás már nem zavarta a felszerelt hőkamera müködését, valamint ez az időszak még nem sértette a 22 LST utáni repülési tilalmat. A vizsgált napokban a naplemente 17.57 UTC-kor volt, így a felvételezés 18.15-19.45 UTC között történt. A mérési eredmények időbeli korrekciója (3.3. fejezet) 19 UTC-re készült.

A felszínhőmérséklet értékek nem csak a mérés idejének időjárási körülményeinek függvényei, hanem az azt megelöző helyzet is alakítja öket. Ennek okán a 12-e és 14-e előtti 36 órás időszak figyelembevétele is indokolt, így kapva egy hosszabb, 86 órás vizsgált időszakot, amit felhőtlen égbolt és csapadékmentes időjárás jellemzett (3.16. ábra). Az OMSZ városi mérőállomásának (5-1, 3.3. ábra) adatai alapján a besugárzás ezen időszak nappali óráiban zavartalan volt, a maximum értékek $810-860 \mathrm{Wm}^{-2}$ között alakultak. A 86 órás időszakban a légmozgás mérsékelt volt $\left(0-4,7 \mathrm{~ms}^{-1}\right)$, a mérések alatt pedig 0,8-3,7 $\mathrm{ms}^{-1}$ közé esett a szélsebesség. A maximum hőmérsékletek $28-36{ }^{\circ} \mathrm{C}$, a minimumok $17-22{ }^{\circ} \mathrm{C}$ között alakultak. Tehát a vizsgált időszak alatt kedvezők voltak az időjárási feltételek a felszíni jellegzetességek mikroklimatikus hatásainak érvényre jutásához.

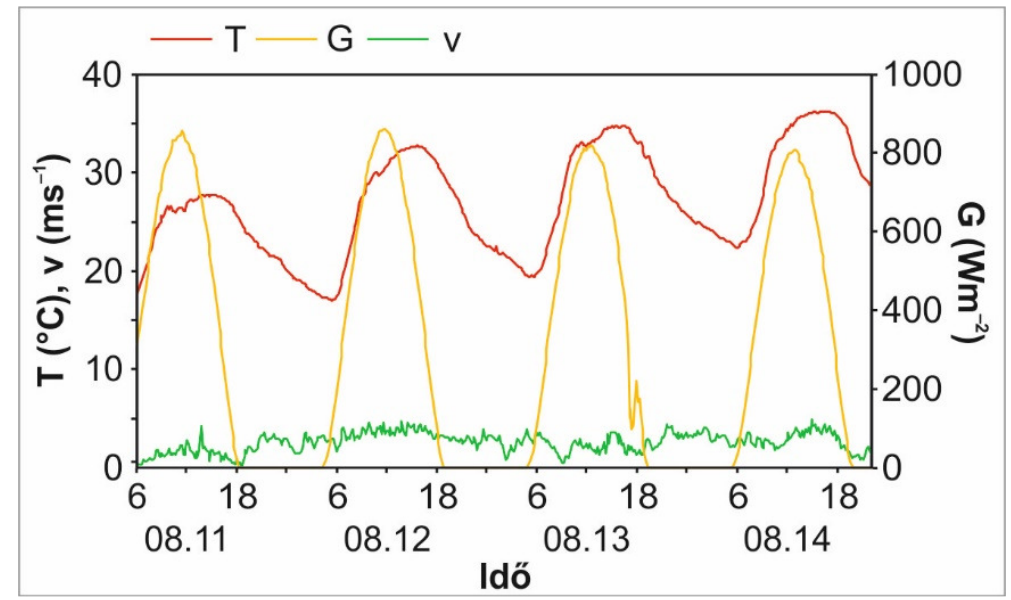

3.16. ábra: A léghőmérséklet (T), globálsugárzás $(\mathrm{G})$ és szélsebesség (v) menete az 5-1 állomáson a mérések idején és az őket megelőző 36 órában (2008.08.11. 6 UTC - 08.14. 20 UTC) (Unger et al., 2010)

\subsubsection{A humánkomfort viszonyok vizsgálata}

A PET kiszámításához szükséges állapothatározók 10 perces átlagértékeit a vizsgálat megkezdésekor rendelkezésre álló leghosszabb időszakra (2014.06.01-2017.01.31.) vonatkozóan használtam fel (7. fejezet). A léghőmérséklet és legnedvesség értékek vala- 
mennyi kiválasztott állomásról, míg a szélsebesség és globálsugárzás értékek az OMSZ állomásáról (D-1, 3.3. ábra) származtak (Unger et al., 2018).

Ebben a vizsgálatban a szegedi állomáshálózat hat állomását választottam ki az alapján, hogy melyek reprezentálják leginkább a Szegeden előforduló egyes LCZ-ket. Az előforduló zónák közül ki kellett hagyni LCZ 8-at, mivel a fentebb említett állomás (82, 3.8.1. fejezet) mellett ebben az időszakban már a 8-1 állomás is jelentős adathiánnyal rendelkezett. Ezek alapján a kiválasztott állomások a következők voltak: 2-1, 3-1, 5-2, 6-8, 9-2 és D-1 (3.3. ábra).

Mivel a kültéri hőérzetet elemzése volt a cél, így azok az évszakok kerültek fókuszba, amikor az időjárás a kültéri szabadidős tevékenységekhez megfelelö, ami Szeged esetében az átmeneti évszakokat és a nyarat jelenti. Továbbá, a teljes nap (24 óra) elemzése helyett, két kiválasztott napszakra szükítettem le a vizsgálatokat. Ezek közül az első a 13 és 14 LST közötti, amikor a legnagyobb hőterhelés feltételezhető a nap folyamán, míg a második a napnyugta utáni 2 órás (esti, szabadidős) periódus. Ezekben a napszakokban a PET értékek 10 napos (dekád) átlagértékeinek évszakok szerinti időbeli változását vizsgáltam, amely elterjedt módszer a humánkomfort vizsgálatok körében, abban az esetben, amikor egy hónapnál finomabb felbontás szükséges (pl. Lin, Matzarakis, 2008; Zaninović, Matzarakis, 2009; Toy, Yilmaz, 2010; Kovács et al., 2016). A továbbiakban - esettanulmányként - egy hőhullámmal jellemzett időszak (2015.08.12-16.) LCZ-k szerinti PET értékeit elemzése történt meg, amely időszakban három egymást követő napon a napi átlaghőmérséklet meghaladta a $27^{\circ} \mathrm{C}$-ot, azaz harmadfokú riasztás volt érvényben (3.17. ábra). Ebben az időszakban a maximum-hőmérsékletek $35,7-37,2{ }^{\circ} \mathrm{C}$, míg a minimum-hőmérsékletek 16,9-19,5 ${ }^{\circ} \mathrm{C}$ között alakultak. A besugárzás zavartalan volt, az értékek valamennyi napon meghaladták a $800 \mathrm{Wm}^{-2}$-t. A légmozgás mérsékeltnek $(0$ $4,8 \mathrm{~ms}^{-1}$ ) tekinthető az utolsó éjszakát leszámítva, ahol a szél már kissé megélénkült.

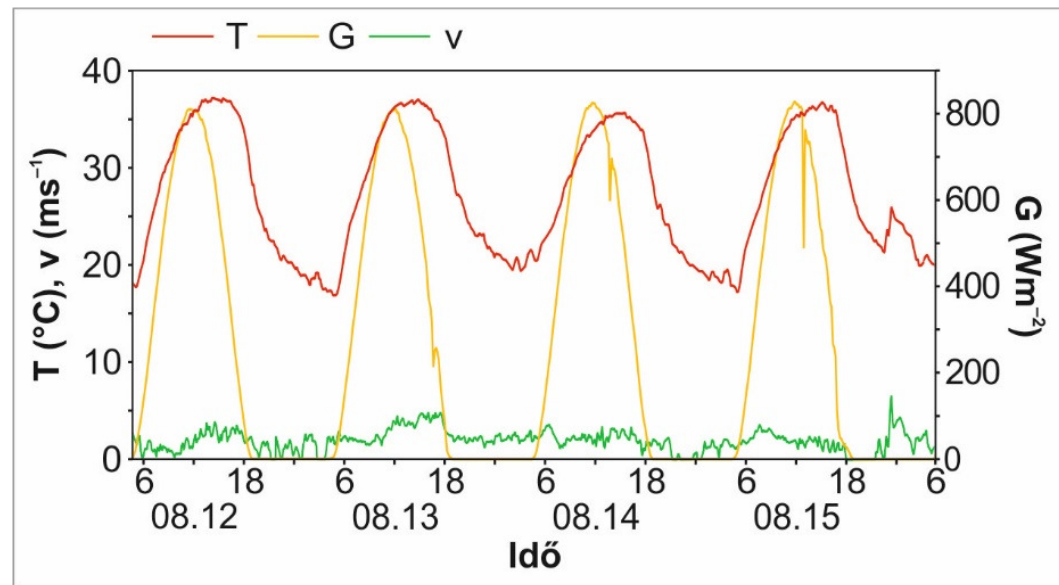

3.17. ábra: A léghőmérséklet $(T)$, globálsugárzás $(\mathrm{G})$ és szélsebesség $(\mathrm{v})$ menete a $\mathrm{D}-1$ állomáson a vizsgált hőhullámos időszakban (2015.08.12. 6 UTC - 08.16. 6 UTC) (Unger et al., 2018)

\subsubsection{Modellezési vizsgálatok}

A modellezés során (8. fejezet) 30 éves átlagidőszakokat alkalmaztam. Referencia időszaknak az 1981-2010 időszakot tekintettem, a jövőbeli, azaz 21. századi változások vizsgálatánál, az első időszak a közeljövőre (2021-2050), míg a második a távolabbi jövőre (2071-2100) vonatkozott. A szükséges napi hőmérséklet, relatív nedvesség és szélmező adatokat a referenciaidőszakra a NOAA (National Oceanic and Atmospheric Ad- 
ministration - Nemzeti Óceáni és Légköri Hivatal) adatbázisból származó mérési adatsor, a jövőbeli időszakokra pedig a 3.5. fejezetben ismertetett EURO-CORDEX klímaszimulációk biztosították.

A kimenetként kapott klímaindexek (3.7. és 8. fejezet) értékeinek validálásához szükség volt egy olyan hosszabb időszakra, amikor a külterületi állomáson (D-1, 3.3. ábra) kívül legalább egy városi állomás adata rendelkezésre állt. Szeged belterületi állomásán (5-1, 3.3. ábra) a mérések 1999-ben kezdődtek meg, ami alapján a referencia időszak egy részére, azaz az 1999-2010 időszakra is elkészítettem a modellezett értékeket, így ezen állomáspár adatainak felhasználásával validálhattam az eredményeket. 


\section{A lokális klímazónák léghőmérsékleti sajátosságai}

A léghőmérséklet klímazónák szerinti, illetve azon belüli vizsgálatánál a szegedi mérőállomás-hálózat, (3.3. ábra, 3.2. fejezet) adatait használtam fel a 2014.06.012015.05.31. közötti egyéves idöszakban (3.8.1. fejezet).

\subsection{A klímazónák közötti termikus különbségek}

\subsection{1. Általános hőmérsékleti körülmények}

A vizsgált egyéves időszak LCZ-k szerinti átlaghőmérséklete, valamint a nyár és a tél átlag-, minimum- és maximum-hőmérsékletei eltérnek egymástól (4.1. táblázat). Az átlaghőmérsékleteknél a tendencia egyértelmü: az értékek a ritkább és alacsonyabb beépítés felé csökkennek. A különbségek nyáron a legnagyobbak, nagysága az LCZ 2 és D között $1,1^{\circ} \mathrm{C}$, míg a legkisebb télen, ekkor ez a különbség $0,7^{\circ} \mathrm{C}$. Ha a maximum-hömérsékletek tekintjük, nem fedezhető fel ilyen egyértelmü tendencia, de mindkét évszakban az LCZ 2 értékei a legmagasabbak. A minimum-hömérsékletek esetében a kompakt LCZ-k rendelkeznek a legmagasabb értékkel, amelyek közül a nyár esetében az LCZ 3 értéke kissé nagyobb, míg télen azonos értékekkel rendelkezik a két zóna. A zónák közötti nagyobb eltérés itt is nyáron jelenik meg, amikor az LCZ 3 és D között $4,4{ }^{\circ} \mathrm{C}$ különbség adódik, ami télen mindössze $1,6^{\circ} \mathrm{C}$. A beépített LCZ-k közötti különbségek a minimum-hőmérsékletek esetében mutatkoznak meg leginkább: a kompakt és nyitott alacsony zónák között ( $\Delta \mathrm{T}_{\mathrm{LCZ}}$ 3-LCZ 6$)$ ez $3,4^{\circ} \mathrm{C}$, míg a kompakt és nyitott közepes zónák között $\left(\triangle \mathrm{T}_{\mathrm{LCZ}} 2_{2} \mathrm{LCZ} 5\right) 2,0^{\circ} \mathrm{C}$. A téli minimumoknál nagyobb különbség a beépített zónák esetében az LCZ 2, 3 és LCZ 8, 9 között jelenik meg, amelynek értéke 1,2 ${ }^{\circ} \mathrm{C}$. Fenner et al. (2017) hasonlóan egy évre vonatkozó mérőállomás-hálózat adatai alapján átlagban $1,2^{\circ} \mathrm{C}$, nyáron $0,9^{\circ} \mathrm{C}$, télen $1^{\circ} \mathrm{C}$ különbséget állapítottak meg az LCZ 2 és D között. Látható, hogy eredményeik évi átlagban hasonló nagyságúak, de az évszakokban megjelenő különbségek eltérnek. Vizsgálatuk magasabb évi átlag különbségéhez leginkább a tavaszi értékek járulnak hozzá, míg esetünkben nyáron voltak nagyobb eltérések.

4.1. táblázat: Szeged lokális klímazónáinak átlaghőmérséklete, valamint nyári és téli átlag-, minimum- és maximum-hőmérséklete (2014.06.01-2015.05.31.) (Skarbit et al., 2017)

\begin{tabular}{|l|c|c|c|c|c|c|c|}
\hline \multirow{2}{*}{ Átlaghőmérséklet } & \multicolumn{7}{|c|}{ LCZ } \\
\cline { 2 - 8 } & $\mathbf{2}$ & $\mathbf{3}$ & $\mathbf{5}$ & $\mathbf{6}$ & $\mathbf{8}$ & $\mathbf{9}$ & $\mathbf{D}$ \\
\hline Évi átlag & 13,2 & 13,2 & 13,0 & 12,8 & 12,3 & 12,6 & 12,3 \\
\hline Nyári átlag & 22,2 & 22,2 & 21,9 & 21,7 & 21,5 & 21,5 & 21,1 \\
\hline Nyári maximum & 35,2 & 34,4 & 33,9 & 34,7 & 34,5 & 34,7 & 34,7 \\
\hline Nyári minimum & 10,8 & 11,3 & 8,8 & 7,9 & 9,8 & 8,7 & 6,9 \\
\hline Téli átlag & 3,6 & 3,6 & 3,6 & 3,2 & 3,2 & 3,3 & 2,9 \\
\hline Téli maximum & 14,6 & 14,1 & 14,1 & 14,5 & 14,3 & 14,5 & 14,4 \\
\hline Téli minimum & $-7,0$ & $-7,0$ & $-7,9$ & $-7,9$ & $-8,2$ & $-8,2$ & $-8,6$ \\
\hline
\end{tabular}

A zónák közötti további különbségek meghatározása érdekében külön vizsgáltuk a nyári hónapokat. Ekkor a sugárzási és energia kicserélődési folyamatok erősebbek, amelynek köszönhetően a különböző beépítettségü zónák és a természetes felszínek termikus reakciói közötti különbségek hangsúlyosabbak. Annak érdekében, hogy ezek az eltérésék még inkább kirajzolódjanak, az évszak ideális napjait (3.8.1. fejezet) tekintettük és ezeken a napokon három időszakot vizsgáltunk: a teljes nap (24 óra), a nappali órák (napkeltétől napnyugtáig), valamint az éjszakai órák (napnyugtától napkeltéig) átlagát 
(4.1. ábra). Mivel ekkor a nappali időszak jelentősen hosszabb, mint az éjszakai (nappal: $63 \%$, éjszaka: $37 \%$ ), ezért ennek köszönhetően az egész napos értékekben a nappali órák dominálnak.

A nappali hőmérsékletek esetében elhanyagolható különbségek vannak az egyes zónák között, az eltérések tulajdonképpen a müszerek mérési pontosságával hasonló mértéküek és egyértelmü tendencia sem figyelhető meg (4.1. ábra). A teljes napot tekintve a különbségek nagyobbak, de ekkor sem haladják meg az $1,5^{\circ} \mathrm{C}$-ot, ugyanakkor itt már megfigyelhetö egy kis mértékü csökkenés a kevésbé beépített zónák felé. Az éjszakai órákban a központi területeken elhelyezkedő és a külterületen fekvő zónák között már egy jelentős, $3,5^{\circ} \mathrm{C}$-os különbség fedezhető fel. Míg a legmagasabb értékek az LCZ 2 $\left(20,4^{\circ} \mathrm{C}\right)$ és LCZ $3\left(20,5^{\circ} \mathrm{C}\right)$ területein jelennek meg, addig az LCZ $9\left(17,3^{\circ} \mathrm{C}\right)$ és LCZ D $\left(16,9^{\circ} \mathrm{C}\right)$ rendelkeznek a legkisebbekkel. Az LCZ 3 és 9 között a zónák sorrendjében az LCZ 8 megelőzi az LCZ 6-ot, ami az erre a zónára jellemző nagyobb vízzáró felszínaránynak köszönhető. Látható, hogy nyáron, forró és napos időjárási körülmények alatt (amikor jellemzők a höhullámok is) az LCZ-k közötti különbségek napközben minimálisak, de éjszaka a sürün beépített zónák (LCZ 2 és 3) hőmérsékletei a nyitott és természetes zónákhoz képest megközelítőleg 3 és $3,5^{\circ} \mathrm{C}$-kal magasabbak maradnak.

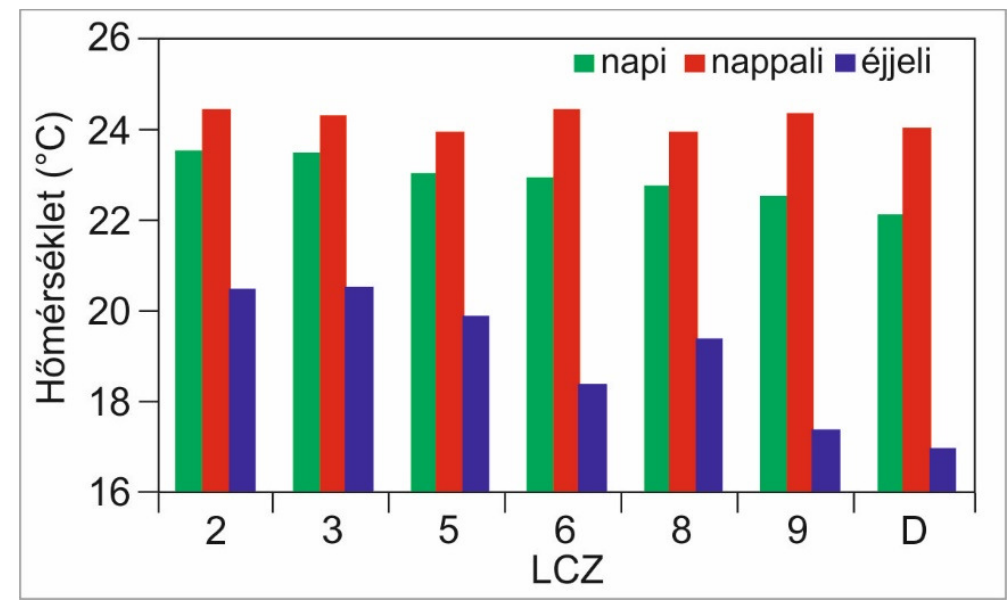

4.1. ábra: Napi, nappali és éjjeli átlaghőmérsékletek lokális klímazónánként nyári ideális napokon (2014. június-augusztus) (Skarbit et al., 2017)

\subsubsection{A hősziget intenzitásának évi, évszakos és napi jellegzetességei}

A 4.2. ábra az éjszaka előforduló legnagyobb, D-1 állomástól (3.3. ábra) számított hőmérséklet-különbségek (azaz a hősziget intenzitás) évi és évszakos átlagait mutatja be lokális klímazónák szerint. Általánosságban elmondható, hogy a legmagasabb értékek az LCZ 9 kivételével nyáron jelennek meg, amelyeket a tavasziak követnek. Ezután következnek az öszi értékek, míg a legkisebb különbségek télen jelentkeznek, az évi átlagok nagysága a tavasziak és ősziek között helyezkednek el.

Az LCZ-k sorrendje átlagos körülmények között, azaz valamennyi időjárási szituációt magában foglalva, mindegyik évszakban megegyezik, csak az évi átlagban tér el kissé (4.2. ábra). A legmagasabb értékek a kompakt zónákban jelentkeznek, amelyek közül az LCZ 3 rendelkezik a legnagyobb intenzitásokkal, ami nyáron $3,8^{\circ} \mathrm{C}$, míg télen $2,2{ }^{\circ} \mathrm{C}$. Az LCZ 2 ugyanezzel a minimum értékkel rendelkezik, de maximuma is csupán $0,2{ }^{\circ} \mathrm{C}$ kal alacsonyabb, azaz a kompakt zónák közötti - az épületmagasság hatását tükrözö különbség nem jelentős. Ezeket a zónákat az LCZ 5 követi, ahol a különbségek nagysága 2,1 és $3,4^{\circ} \mathrm{C}$ között alakul. A sorrend az LCZ 6 és 8 esetében nem azonos minden időszakban, ugyanis télen az LCZ 6 a melegebb, de nagyon minimális eltéréssel. A többi 
évszakban és évi átlagban is az LCZ 8 különbség értékei nagyobbak, maximális értéke $3{ }^{\circ} \mathrm{C}$, míg a minimum $1,3{ }^{\circ} \mathrm{C}$, amely értékek az LCZ 6-ban rendre 2,5 és $1,5^{\circ} \mathrm{C}$. Valamennyi időszakban az LCZ 9 hőmérséklet-különbségei a legkisebbek $\left(1,2-1,6^{\circ} \mathrm{C}\right)$ és éves ingásuk sem jelentős mértékü. Amennyiben a beépített zónák közötti eltérésekre koncentrálunk, a legnagyobb különbség $\left(2,4{ }^{\circ} \mathrm{C}\right)$ nyáron jelenik meg az LCZ 3 és 9 között.

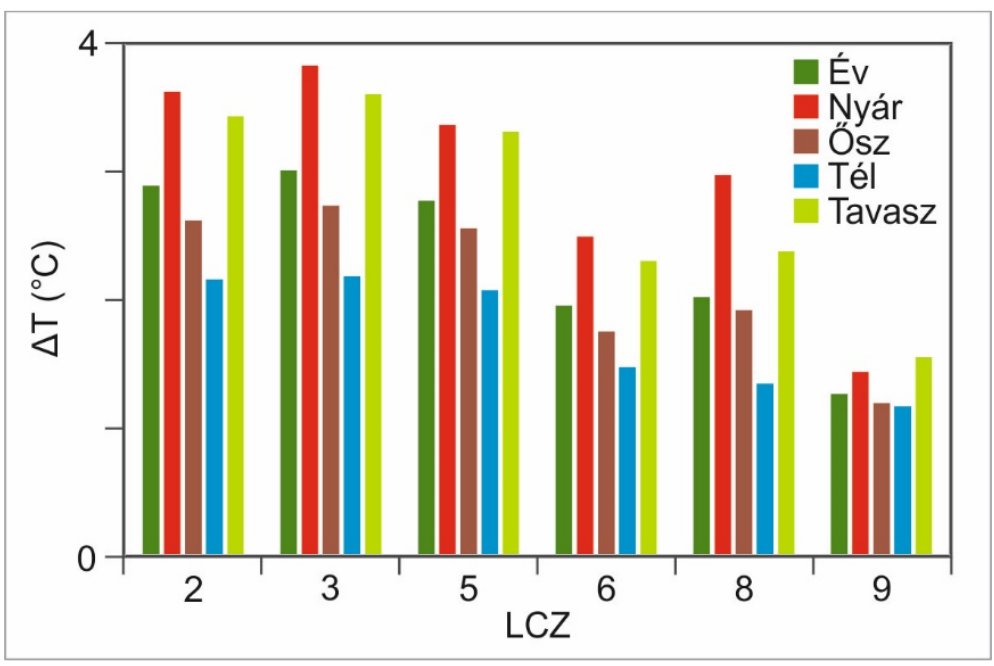

4.2. ábra: Az éjszakai legnagyobb hőmérséklet-különbségek (D-1 állomástól számítva) évi és évszakos átlagai az egyes lokális klímazónákban Szegeden (2014.06.01. - 2015.05.31.) (Gál et al., 2016)

A fentieket a hősziget kialakulásának szempontjából ideális körülmények között (3.8.1. fejezet) és csak az éjszakai maximumra vonatkozóan vizsgálva, nem feltétlenül nyáron jelentkeznek a legmagasabb különbség értékek (4.3. ábra). Ideális napokon - a tél kivételével - az egyes klímazónákon belül az évszakok közötti eltérések nem jelentősek. A legnagyobb intenzitások az LCZ 3, 5 és 9 esetében ősszel jelennek meg, míg az LCZ 8-ban a tavaszi különbség az öszit is meghaladja. A zónák többségében jelen esetben is a tél értékei a legkisebbek, de az LCZ 9-ben a tavaszt csak $0,1{ }^{\circ} \mathrm{C}$-os hömérsékletkülönbség jellemzi. Az évi értékek itt már a nyári és őszi különbségek között helyezkednek el, de az LCZ 8-ban a tavasziak is magasabbak.

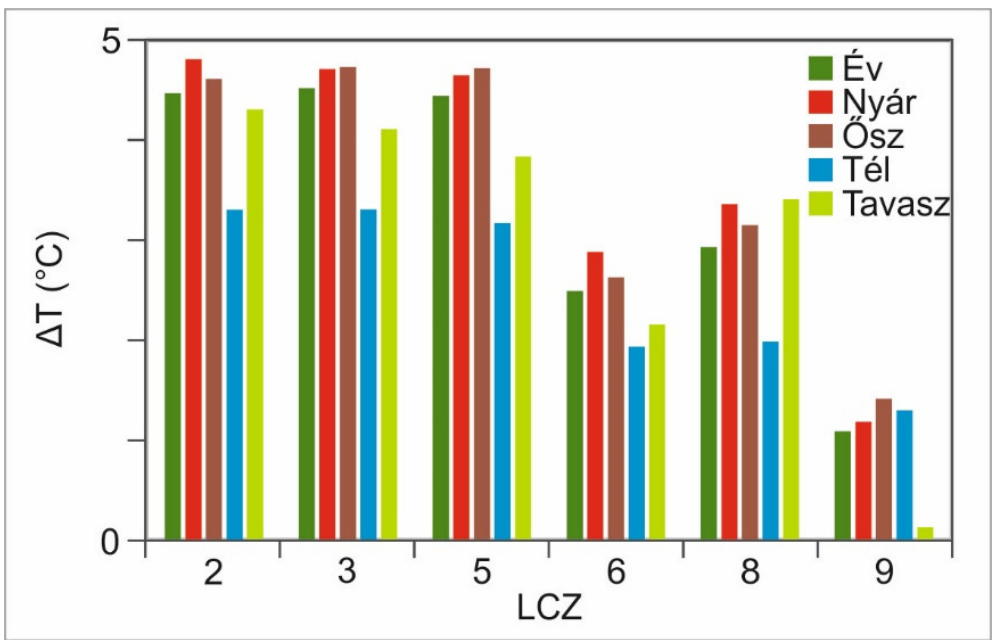

4.3. ábra: Az éjszakai legnagyobb hőmérséklet-különbségek (D-1 állomástól számítva) évi és évszakos átlagai az egyes lokális klímazónákban ideális napokon Szegeden (2014.06.01 2015.05.31.) (Gál et al., 2016) 
Két évszakban és évi átlagban a legnagyobb különbségek $\left(3,3-4,7^{\circ} \mathrm{C}\right)$ ismét az LCZ 3-ban jelennek meg, míg a nyári $\left(4,8^{\circ} \mathrm{C}\right)$ és tavaszi $\left(3,3^{\circ} \mathrm{C}\right)$ különbségek az LCZ 2ben a legmagasabbak (4.3. ábra). Tehát a két kompakt zóna ideális körülmények között sem tér el nagyobb mértékben és az LCZ 5 is hasonló mértékü intenzitásokat $\left(3,2-4,7^{\circ} \mathrm{C}\right)$ mutat. Ezektől a zónáktól látványosan elkülönülnek az LCZ 6, 8 és 9 értékei, ahol a zónák sorrendje valamennyi időszakban megegyezik: LCZ $8\left(2,0-3,4{ }^{\circ} \mathrm{C}\right), \operatorname{LCZ} 6\left(1,9-2,9{ }^{\circ} \mathrm{C}\right)$ és LCZ $9\left(0,1-1,4^{\circ} \mathrm{C}\right)$. Az LCZ 9-ben tavasszal megjelenő alacsony különbség miatt ebben az évszakban a legnagyobb az évszakos eltérés. Az LCZ-k értékei közötti legkisebb, télen megjelenő évszakos különbség is nagyobb $2{ }^{\circ} \mathrm{C}$-nál, azaz az átlagos helyzethez képest az ideális körülmények között - a vártnak megfelelöen - nagyobbak a zónák közötti termikus eltérések.

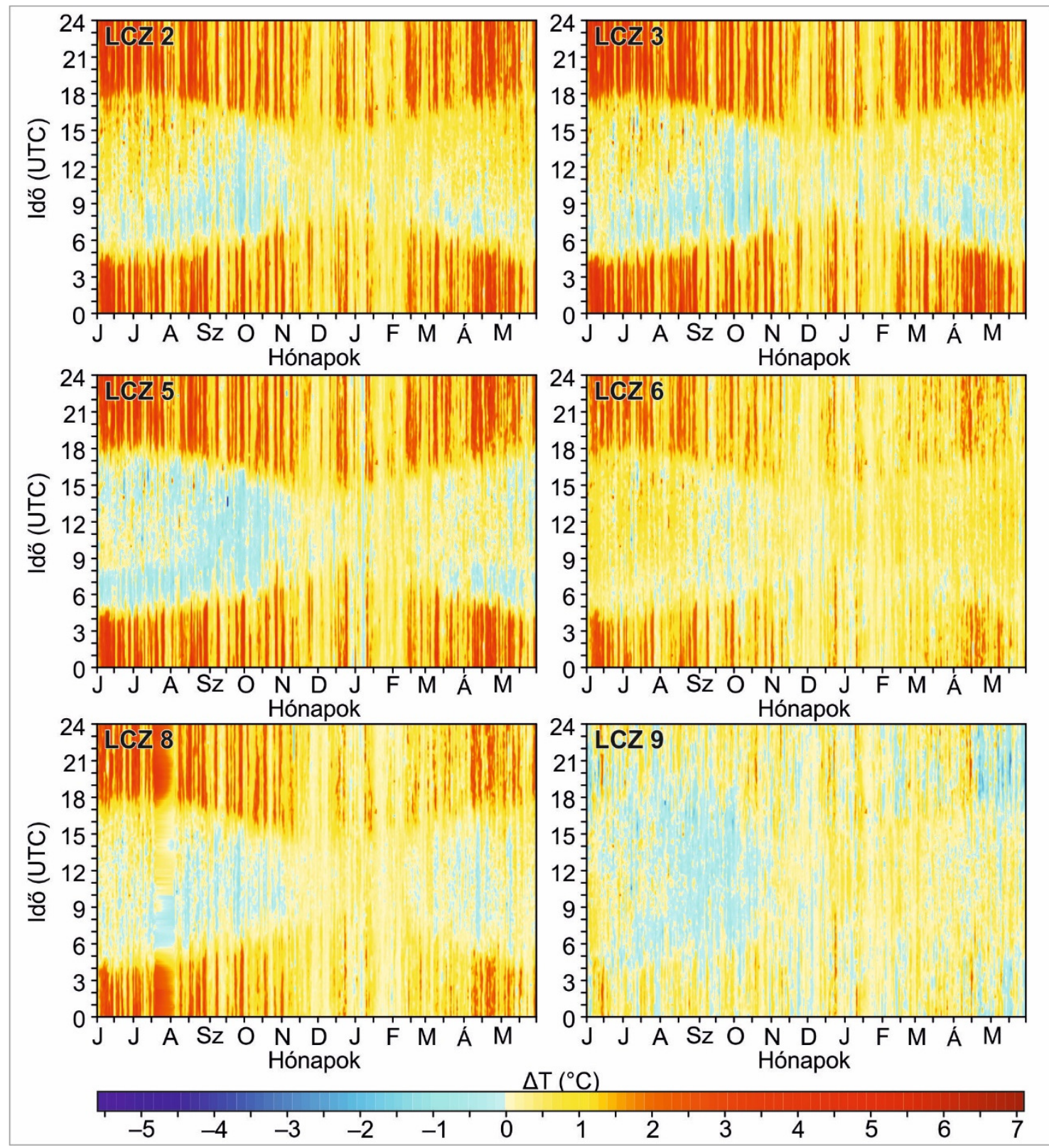

4.4. ábra: A 10-perces hőmérséklet-különbségek D-1 állomástól számított évi és napi változása az egyes lokális klímazónákban Szegeden (2014.06.01. - 2015.05.31.) (Gál et al., 2016; Skarbit et al., 2017) 
A kapott eredmények összehasonlítása más európai városokkal nehézkes, hiszen ezek a vizsgálatok nagyrészt időszakos méréseken alapulnak (többnyire néhány napról van szó) és nem fedik le valamennyi zónát. Általánosságban elmondható, hogy valamennyi esetben a kompakt zónák értékei nagyobb mértékben eltérnek a külterülettől (LCZ D), mint a nyitott zónáké és a ritkán beépített LCZ 9 hőmérséklet-értékei a legkisebbek. Az LCZ 8 értékei átlagban melegebbek, mint az LCZ 6-é. A legnagyobb hőmérséklet-különbség az LCZ 2 és D között más városok esetében 4 és $6{ }^{\circ} \mathrm{C}$ között alakul: Uppsala, Svédország: $6{ }^{\circ} \mathrm{C}$ (Stewart, 2011), Dublin, Írország: $5{ }^{\circ} \mathrm{C}$ (Alexander, Mills, 2014), Nancy, Franciaország: $4{ }^{\circ} \mathrm{C}$ (Leconte et al., 2015) és Berlin, Németország: $4{ }^{\circ} \mathrm{C}$ (Fenner et al., 2017).

A zónák szerinti hőmérséklet-különbségek évi és napi változásának együttes ábrázolása révén jól láthatóan megkülönböztethető az éjszakai és nappali órák, valamint az egyes évszakok (4.4. ábra). Ezek az elkülöníthető mintázatok egyértelmúen és tisztán észrevehetők - az LCZ 9 kivételével - valamennyi zónában. E kivétel esetében a különbségek a vizsgált időszak döntő többségében elhanyagolhatók és egyértelmü tendenciát sem vehetünk észre, azaz ez a beépítés típus befolyásolja legkevésbé a hőmérséklet változását a külterülethez képest. A negatív és pozitív különbségek választóvonala az év során jól láthatóan követi a napkelte és napnyugta időpontját. A napszakok és évszakok közötti eltérés a kompakt zónákban és az LCZ 5-ben a leghangsúlyosabb. Ezekben a zónákban a $4{ }^{\circ} \mathrm{C}$ feletti intenzitások hosszabb időszakon keresztül fennmaradnak éjszakánként, de $6{ }^{\circ} \mathrm{C}$-ot elérö eltérések is megjelennek néhány alkalommal. Ha az LCZ 6 és 8-at tekintjük, az éjjeli és nappali órák értékei közötti különbség leginkább már csak nyáron jelentős, ősszel és tavasszal már nem akkora mértékü, mint az előző zónák esetében, míg télen már el is tünik.

Az 4.4. ábrán egy másik fontos jelenség is megjelenik, ami nem más, mint a nappali órákat meghatározó városi hủvös sziget, amely az LCZ 2, 3 és 5 esetén a legfeltünőbb, értékei -1 és $-1,5^{\circ} \mathrm{C}$ között változnak. Ennek kialakulása az egymáshoz közelálló épületek árnyékoló hatásának tudható be, aminek köszönhetően ezeken a területeken a nappali hőmérsékletek - föként délelőtt - alacsonyabbak is lehetnek, mint a külterületen. A jelenség gyakorlatilag valamennyi zónában, még ha kis mértékben is, de megjelenik. Az évszakok közül télen jellemző a legkevésbé, az év többi részében általánosságban elmondható, hogy délelőtt (ősz esetében szinte a nappal teljes részében) az erősebben beépített zónák hüvösebbek, mint a külterület. A kevésbé beépített zónák közül megjelenése kevésbé látványos az LCZ 8-ban és alig észrevehetö az LCZ 6-ban.

Fenner et al. (2014) hasonló évi és napi menetet vizsgált az LCZ 5, 6 és A zónákban, referencia állomásuk az LCZ B-ben helyezkedett el. Az LCZ 5-ben éjszaka egész évben szintén pozitív különbségeket kaptak, amelynek nagysága nyáron meghaladta a $6{ }^{\circ} \mathrm{C}$-ot. Ebben a vizsgálatban is az LCZ 6 hasonló menetet, ugyanakkor kisebb intenzitás értékeket mutatott. A nappali hüvös szigetet szintén októberig mutatták ki és a déli órákban pozitív értékeket kaptak.

\subsubsection{Klímaindexek változása}

A lokális klímazónák közötti további különbségek megismerése céljából megvizsgáltam az ún. klímaindexek zónák szerinti változását. Ezeket a klímaindexeket egy reláció definiálja, és értékük azon napok számával egyenlő, mely napokon egy adott hőmérsékleti érték meghaladja (,meleg” indexek) vagy éppen nem éri el (,hideg” indexek) a meghatározott küszöbértéket. Az 4.2. táblázatban a hideg és meleg indexeket a könnyebb követhetőség érdekében egy megvastagított vonal különíti el. Jelen vizsgálatban a 3.4. 
táblázatban leírt, a cuboid módszer (3.7. és 8. fejezet) kimeneteinek számító klímaindexeket továbbiakkal egészítettem ki, amelyeknek nagyrésze hideg index, továbbá két, átlaghőmérsékleten alapuló meleg index (4.2. táblázat).

4.2. táblázat: Az egyes klímaindexek számának alakulása lokális klímazónánként Szegeden (2014.06.01-2015.05.31.) (Skarbit et al., 2017)

\begin{tabular}{|c|c|c|c|c|c|c|c|}
\hline \multirow{2}{*}{ Klímaindexek } & \multicolumn{7}{|c|}{$\mathbf{L C Z}$} \\
\hline & 2 & 3 & 5 & 6 & 8 & 9 & D \\
\hline Fagyos nap $\left(T_{\min }<0{ }^{\circ} \mathrm{C}\right)$ & 35 & 37 & 36 & 47 & 45 & 51 & 60 \\
\hline Hideg nap $\left(\mathrm{T}_{\text {átlag }}<0^{\circ} \mathrm{C}\right)$ & 13 & 13 & 13 & 13 & 13 & 14 & 14 \\
\hline Téli nap $\left(\mathbf{T}_{\max }<0^{\circ} \mathrm{C}\right)$ & 8 & 8 & 8 & 8 & 8 & 8 & 8 \\
\hline Fütési nap $\left(\mathrm{T}_{\text {átlag }}<15^{\circ} \mathrm{C}\right)$ & 190 & 191 & 192 & 193 & 194 & 195 & 203 \\
\hline Hütési nap $\left(\mathrm{T}_{\text {átlag }}>18,3^{\circ} \mathrm{C}\right)$ & 121 & 120 & 117 & 113 & 112 & 111 & 103 \\
\hline Meleg nap $\left(\mathrm{T}_{\text {átlag }}>20^{\circ} \mathrm{C}\right)$ & 87 & 89 & 84 & 79 & 78 & 77 & 71 \\
\hline Nyári nap $\left(T_{\max } \geq 25^{\circ} \mathrm{C}\right)$ & 98 & 90 & 82 & 94 & 86 & 96 & 89 \\
\hline Höségnap $\left(\mathrm{T}_{\max } \geq \mathbf{3 0}{ }^{\circ} \mathrm{C}\right)$ & 33 & 30 & 22 & 30 & 26 & 28 & 24 \\
\hline Sörkerti nap $\left(\mathrm{T}_{20 \mathrm{~h}^{*}} \geq 20^{\circ} \mathrm{C}\right)$ & 95 & 97 & 91 & 79 & 83 & 71 & 65 \\
\hline Nyári este $\left(\mathrm{T}_{22 \mathrm{~h}^{*}} \geq 20^{\circ} \mathrm{C}\right)$ & 68 & 71 & 64 & 44 & 41 & 42 & 38 \\
\hline Meleg éjszaka $\left(T_{\min } \geq 17^{\circ} \mathrm{C}\right)$ & 53 & 55 & 49 & 40 & 41 & 38 & 30 \\
\hline Trópusi éjszaka $\left(T_{\min } \geq 20^{\circ} \mathrm{C}\right)$ & 14 & 18 & 10 & 4 & 7 & 3 & 0 \\
\hline
\end{tabular}

*Közép-európai nyári idő

A hideg indexek esetében általánosságban megállapítható, hogy a napok száma növekszik a kompakt zónák felöl a külterületi LCZ D felé haladva (4.2. táblázat). Ez a különbség a legszembetünőbb a fagyos és fütési napok esetében. Az LCZ D-hez viszonyított százalékban kifejezett relatív eltérés szerint a fagyos napok esetén látható a legnagyobb különbség a zónák között (4.5. ábra). Ez a nagyobb eltérés annak köszönhető, hogy az index definíciója a minimum-hőmérsékleten alapul, amelynek segítségével tulajdonképpen az éjszakai különbségekre fókuszál, amikor a hősziget hatása leginkább érvényesül. Ezáltal a fagyos napok száma megközelítőleg $40 \%$-kal kevesebb a kompakt zónákban (LCZ 2 és 3) és az LCZ 5-ben, mint az LCZ D-ben. A napi átlaghőmérsékleten alapuló fütési napok esetében nem jelentkezik ekkora mértékü eltérés, az LCZ 2 értéke csupán 6,5\%-kal kisebb, mint az LCZ D-re jellemző (4.5. ábra). A különbség a hideg napok esetén még tovább csökken - ahol már csak az LCZ 2-8 és LCZ 9, D csoportok között fedezhető fel 1 nap eltérés - majd a téli napoknál már nem is jelentkezik (4.2. táblázat).

A meleg indexek sora két-két átlag-, maximum- és minimum-hőmérséklet alapú, valamint két konkrét időponthoz köthető indexből áll (4.2. táblázat). Látható, hogy a hasonló hőmérsékleti értékkel definiált meleg indexek tendenciája közel azonos (4.2. táblázat), csak nagyságuk tér el, így az 4.5. ábrán ezek közül csak egy-egy van feltüntetve. Nagy részüknél - tulajdonképpen csak a maximum-hőmérséklettel definiált indexeket leszámítva - a tendencia egyértelmű: a napok száma a kompakt zónák (LCZ 2 és 3) felől az LCZ D felé haladva csökken. Ezeknél az indexeknél (a hütési nap kivételével) az LCZ 3 értékei kismértékben nagyobbak, mint az LCZ 2-re jellemzök, azaz maga a kompakt beépítés az igazán befolyásoló tényező, mint azon belül az épületek magassága. Emellett, az ilyen irányú különbségek fellépésében az állomások környezetében fellépő, mikroskálájú hatások is közrejátszhatnak. Az időpontokra, valamint a $T_{\min }$-re jellemző indexeknél az LCZ-k számát követő csökkenő tendenciát megzavarja az LCZ 8, amelynek értékei ezen indexek esetében nagyobbak az LCZ 6-énál. Már korábban is láthattuk (pl. 4.1. ábra), hogy az éjszaka folyamán LCZ 8 jellemzően magasabb hőmérsékleteket mu- 
tat, mint az LCZ 6, ami feltehetőleg annak köszönhető, hogy vízzáró felszínaránya jellemzően nagyobb, hiszen kevesebb növényzettel rendelkezik. A kompakt beépítés és az LCZ D közötti legnagyobb különbségek a szigorúbb határok esetében mutatkoznak meg a leginkább, gondolva itt pl. a nyári estére vagy a meleg éjszakára, ahol $80 \%$ körül alakulnak (4.5. ábra). Továbbá, ha megfigyeljük a trópusi éjszakák számát (itt a relatív eltérés számolása nem lehetséges), akkor láthatjuk, hogy LCZ 9-hez képest is hatalmas mértékủ a változás (megközelítőleg 400-500\%) (4.2. táblázat). A leginkább nyáron jellemzö, a $T_{\max }$-hoz köthető nyári nap és hőségnap esetében nem figyelhető meg ilyen egyértelmü tendencia, ugyanis a kompakt zónák mellett az LCZ 6 és 9 is kiemelkedő értékkel rendelkezik. Az LCZ D-hez viszonyított relatív eltérés a hőségnapok esetében az LCZ 2nél 38\%, míg az LCZ 3 és 5 esetében 25\% (4.5. ábra).

A fenti megállapítások összhangban vannak a korábbiakkal, azaz az éjszakai minimum-hömérsékletekkel definiált indexek adják a legnagyobb eltéréseket a zónák között, illetve a külterülettől míg a maximum-hőmérséklet alapúak a legkisebbeket.

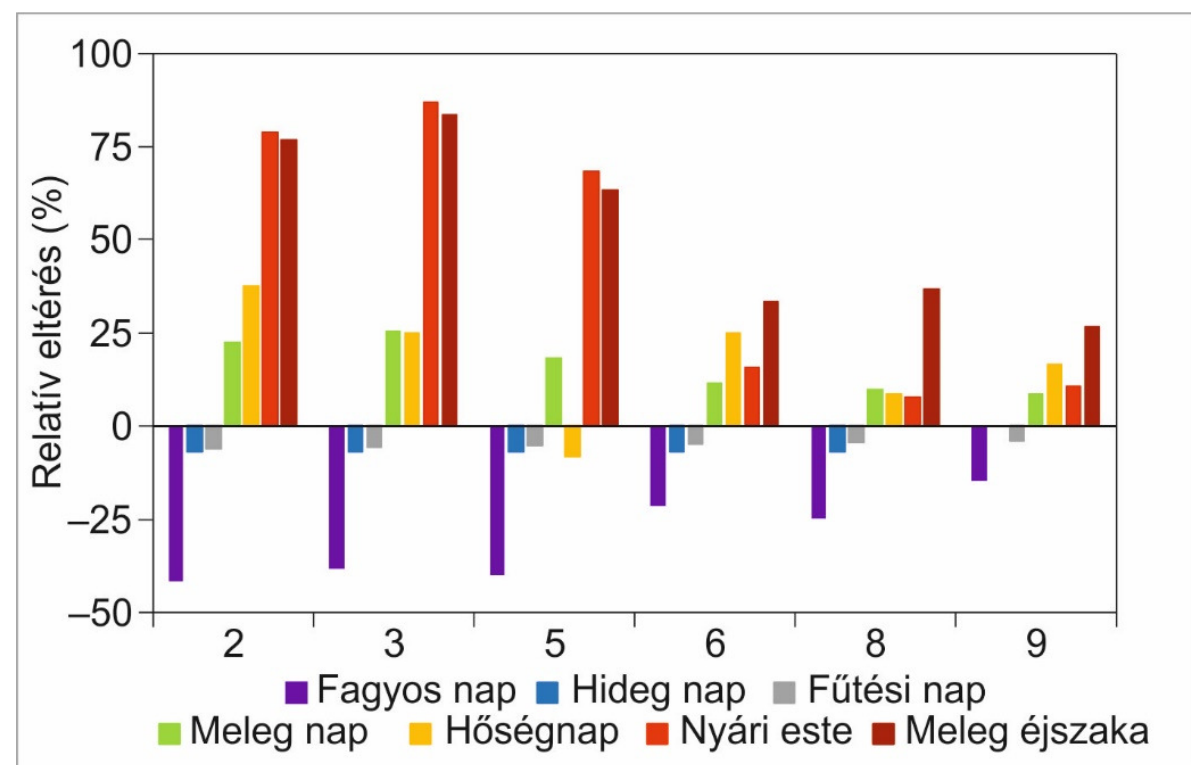

4.5. ábra: Klímaindexek számának relatív eltérése a D-1 állomástól lokális klímazónánként Szegeden (2014.06.01-2015.05.31.) (Skarbit et al., 2017)

\subsection{Az egyes klímazónákon belüli termikus különbségek}

A szegedi mérőállomás-hálózat vizsgálatának céljából az LCZ-ken belül megjelenő (intra-zonális) különbségeket is elemeztem, amire három zónában adódott lehetőség. Ennek során az LCZ 5, 6 és 9 esetében rendre 4, 9 és 2 állomás alapján egész évben, illetve a nyár 12 ideális napján (3.8.1. fejezet) vizsgáltam az állomások közötti eltéréseket.

Elsőként a nyári ideális napokon napszakos viszonylatban három időszak átlagait tekintettem: napi (teljes 24 óra), nappali (napkeltétől napnyugtáig) és éjszakai (napnyugtától napkeltéig). A 4.6 ábra alapján általánosságban megállapítható, hogy az LCZ 5 és 9 kisebb, mint $1{ }^{\circ} \mathrm{C}$-os intra-zonális különbséget mutat, míg az LCZ 6-ban az eltérések már meghaladják ezt az értéket. Ezek a kismértékü, osztályon belüli eltérések az állomások mikroskálájú környezetének hatásait tükrözik, gondolva itt a közvetlen környezetük felszínborítására és az antropogén hőforrásokra (pl. jármüforgalom). 


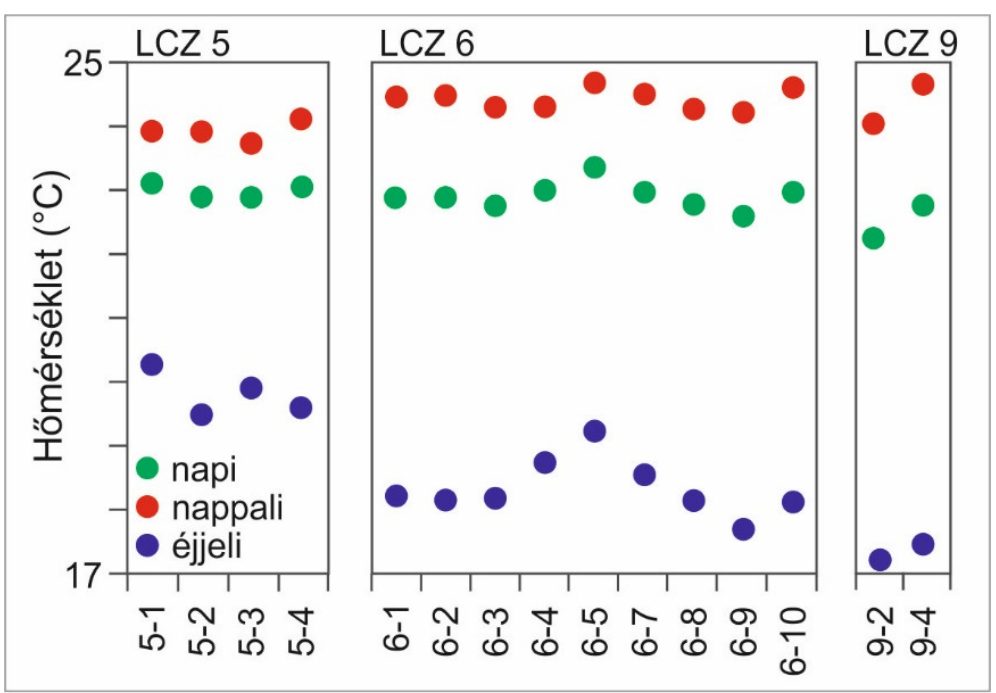

4.6. ábra: Az LCZ 5, 6 és 9 állomásainak napi, nappali és éjszakai átlaghőmérsékletei nyári ideális napokon Szegeden (2014. június-augusztus) (Skarbit et al., 2017)

Részletesebben elemezve, az LCZ 5 állomásai esetében a napi és nappali hömérsékletkülönbségek elenyészők, értékük megközelítőleg 0,1 és $0,3{ }^{\circ} \mathrm{C}$ között alakul, míg éjszaka valamivel magasabbak, de ekkor se haladják meg a $0,8^{\circ} \mathrm{C}$-ot (4.6. ábra). Ezek az eltérések az állomások városon belüli elhelyezkedésével magyarázhatók: míg az 5-1 és 5-3 állomások a belvároshoz, addig az 5-2 és 5-4 állomások a külterülethez közelebb helyezkednek el (3.3. ábra). Ennek köszönhetően az utóbbi két állomás a hősziget kialakulásának szempontjából ideális körülmények között ki van téve a vidéki területről érkező hüvös/hideg levegő beáramlásának (Unger, Gál, 2017). Az LCZ 6 esetében a napi és nappali különbségek hasonlóan alacsony mértéküek, megközelítőleg $0,5^{\circ} \mathrm{C}$-os értéket érnek el, azonban éjszaka az eltérések már jelentősnek mondhatók, ugyanis a 6-5 állomás már $1,5^{\circ} \mathrm{C}$-kal melegebb, mint a 6-9. Ez a nagyobb különbség ebben a zónában is az állomások elhelyezkedéséhez köthető: a 6-5 állomás központhoz közeli területen található, míg a 6-9 állomás peremi helyzetének köszönhetően ki van téve a hüvös vidéki szellő hatásának. Az LCZ 9 két vizsgált állomásának esetében a legnagyobb különbség nappal jelenik meg, amely nem éri el az $1{ }^{\circ} \mathrm{C}$-ot, és éjszaka csupán $0,4^{\circ} \mathrm{C}$ körül alakul. A két állomás közötti eltérés szintén a városon belüli elhelyezkedésüknek tulajdonítható, hiszen a 9-4 állomás a térségben uralkodó északnyugati szél hatása alatt áll (Péczely, 1979) (3.3. ábra).

Az éjszakai órákra jellemző termikus különbségek további vizsgálatánál a D-1 állomástól számított hősziget intenzitás éjszakai maximumainak átlagát vettem figyelembe, külön a nyári ideális napokra és a teljes évre vonatkozóan (4.7. ábra). A nyári ideális napok intenzitásai $1,5^{\circ} \mathrm{C}$-kal magasabb, mint az évi átlagos különbségek az LCZ 5-ben. Ez az érték az LCZ 6-ban az egyes állomás függvénye, a legtöbb esetben csak néhány tized ${ }^{\circ} \mathrm{C}$ eltérést láthatunk. A különbség tovább csökken, ha az LCZ 9-et tekintjük, az értékek a vizsgált időszaktól függetlennek tekinthetők. Általánosságban, az állomások közötti legnagyobb különbség az LCZ 5 és 6 esetében a nyári ideális napokon jelenik meg. Míg ez az eltérés az LCZ 5-ben esetében nem haladja meg az $1{ }^{\circ} \mathrm{C}$-ot (5-2 és 5-4 között), addig az LCZ 6-ban közel $2{ }^{\circ} \mathrm{C}$-os eltérést vehetö észre (6-9 és 6-5 között). Az LCZ 5-ben a két esetet együtt tekintve az 5-3 és 5-4 állomások értékei magasabbak, ugyanakkor ez csak pár tized ${ }^{\circ} \mathrm{C}$-ot jelent. Az LCZ 6-ban a 6-5 állomás emelkedik ki leginkább, amelyet a 6-4, majd a 6-7 követ. A 6-9 adja a legkisebb értékeket, míg a többi állomás közel azonos hőmérséklet-különbségeket mutat. 


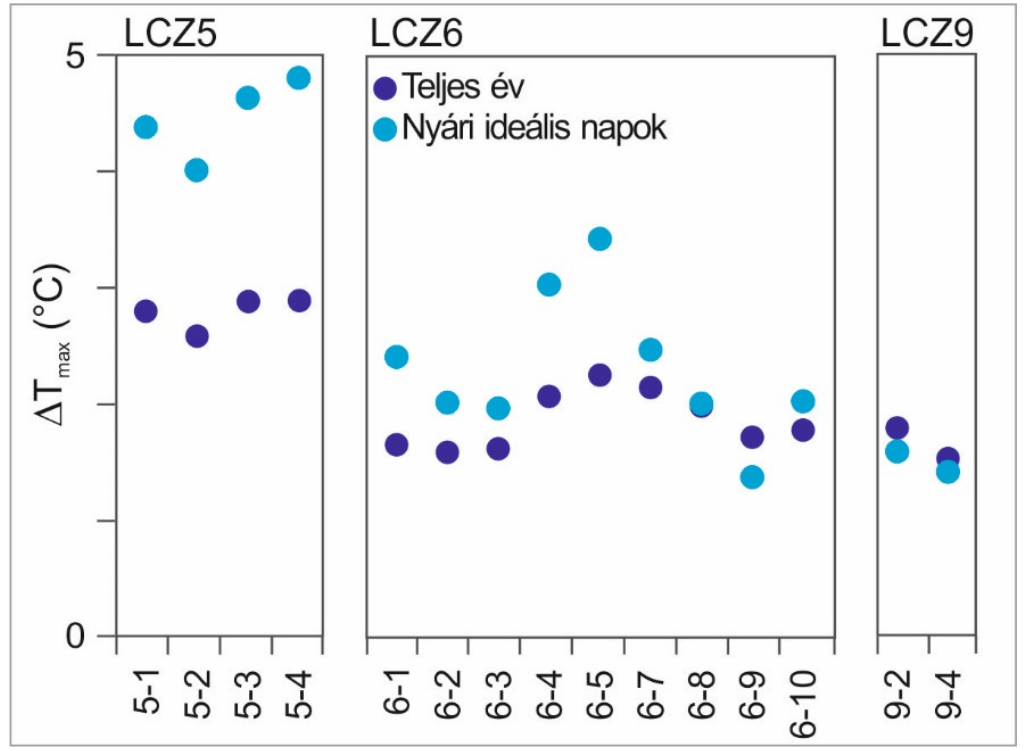

4.7. ábra: Az LCZ 5, 6 és 9 állomásainak az éjszakai legnagyobb hősziget intenzitás átlagai a teljes évben (2014.06.01. - 2015.05.31.), illetve nyári ideális napokon (2014. június-augusztus), a D-1 állomástól számítva Szegeden (Skarbit et al., 2017)

A fenti eredmények alapján megállapítható, hogy az LCZ-ken belüli különbségek nem haladják meg a zónák közötti eltéréseket. A zónákon belüli különbségekre ugyancsak berlini vizsgálatok térnek ki, amelyek hasonló megállapításra jutottak. Fenner et al. (2017) a lakossági forrású crowd-sourced adatok alapján elemezték az állomások közötti különbségeket, amelyek szintén nyáron és éjszaka voltak a legnagyobbak. A legnagyobb eltérés a legtöbb müködő állomás esetében, azaz az LCZ 6-ban és augusztusban volt. Ennek nagysága $6,6^{\circ} \mathrm{C}$-nak adódott, amely érték az ilyen forrású adatok gyenge minőségére is utal. Quanz et al. (2018) a jelen esetben nem vizsgált LCZ 2-ben elemezték egy mérési kampány során kapott nyári intra-zonális különbségeket. Esetükben is az éjszakai különbség $1{ }^{\circ} \mathrm{C}$ körül alakult, de amikor csak a kedvező körülményü estéket tekintették, akkor már $3{ }^{\circ} \mathrm{C}$-os értéket detektáltak (esetünkben az LCZ 6-nál $2{ }^{\circ} \mathrm{C}$ volt). Ez a tendencia arra utalhat, hogy a Szegeden is nagyobb lehet a kompakt zónákbeli eltérés, noha figyelme kell venni, hogy a berlini müszerek pontossága csak $\pm 0,5^{\circ} \mathrm{C}$ volt. 


\section{A városi hőmérsékleti mintázat térbeli-időbeli dinamikája}

A hőmérséklet városon belüli területi szerkezetének feltárása érdekében a D-1 állomástól számított állomások szerinti hőmérséklet-különbségek interpolált értékeit vizsgáltam. Ennek megvalósítására az állomáshálózat (3.2. fejezet) egyéves adatsorát használtam fel a teljes időszak és az ideális napok átlagát tekintve (3.8.1. fejezet). Az előző fejezetben már áttekintettük a hősziget intenzitás lokális klímazónák szerinti alakulását (4.1.2.), ugyanakkor fontos, hogy az LCZ-knek az UHI térbeli mintázatára gyakorolt hatása is bemutatásra kerüljön, aminek vizsgálatára egy „,kiemelten” ideális nap éjszakájára esett a választás (2014.08.29-30). A hőmérsékleti gradiensek területi eloszlását - a hőmérsékleti mintázat dinamikájának megértése érdekében - ideális körülmények között vizsgáltam, emellett az értékek lokális klímazónák szerinti változását valamennyi feltétel mellett elemeztem.

5.1. Az évi átlagos hősziget mintázat fel- és leépülése a teljes időszakban és az ideális napokon

A hősziget formája és intenzitása nagyban függ a megelőző és az adott időszakban uralkodó időjárási viszonyoktól, valamint a vidéki és városi területek eltérő szerkezetétől és felszínborításától (Oke, 1987). Ezen meteorológiai és strukturális viszonyok határozzák meg az egyes lokális klímazónák, így a városi terület lehülési és melegedési képességét. Ezek alapján az UHI fejlődését (fel- és leépülését) érdemes termikus térképek időbeli sorozatával ábrázolni. Ennek megvalósítására az állomáshálózat adatai alapján ábrázoltam az átlagos éves hősziget-intenzitás éjszakai mintázatát a napnyugta előtti 1 órától a napnyugta utána 13 óráig a D-1 állomástól vett eltérés alapján.

Az 5.1. ábra az adott időszak évi átlagát mutatja be, azaz valamennyi időjárási szituációt tartalmazza, beleértve a kedvezőtleneket is, amelyek esetében a város hatása kevésbé érvényesül. Látható, hogy napnyugta elött nincs jellegzetes mintázat, az UHI napnyugtakor kezd kifejlődni és hamar, a következő 2 órában eléri maximális intenzitását. Átlagos viszonyok között csak egy viszonylag gyenge hősziget tud kifejlődni, amelynek maximális intenzitása $2{ }^{\circ} \mathrm{C}$ körüli és leginkább a városközpontban érzékelhetö. A napnyugta utáni 3 óráig negatív értékek is megjelennek egy kis területen a város nyugati részén, amelynek oka a város e területén jellemző apróbb tavak mikroklimatikus hatása.

A hősziget az éjszaka hátralévő részében hasonló erősségű marad, későbbi gyors csökkenése a napnyugta utáni 10. és 11 . órára tehető (5.1. ábra). Az $1{ }^{\circ} \mathrm{C}$-os különbség izotermája +1 . órától +8 . óráig közel állandó marad, az általa jelölt terület északnyugati és délnyugati irányokba nyúlik el a város majdnem egészét magában foglalva. A mintázat már ezen átlagos körülmények között is kijelöli a legsürübben beépített lokális klímazónákat, amelyek magasabb hőtöbblettel rendelkeznek ami már a napnyugta után 1 órával megjelenik és a +9 . óráig tart. Kiterjedése az éjszaka folyamán alig változik, a csökkenés a napnyugta után 8 órával kezdődik meg. A +10 . óra után az UHI leépülése kezdődik meg és a $+12-13$. órában teljesen megszünik. 

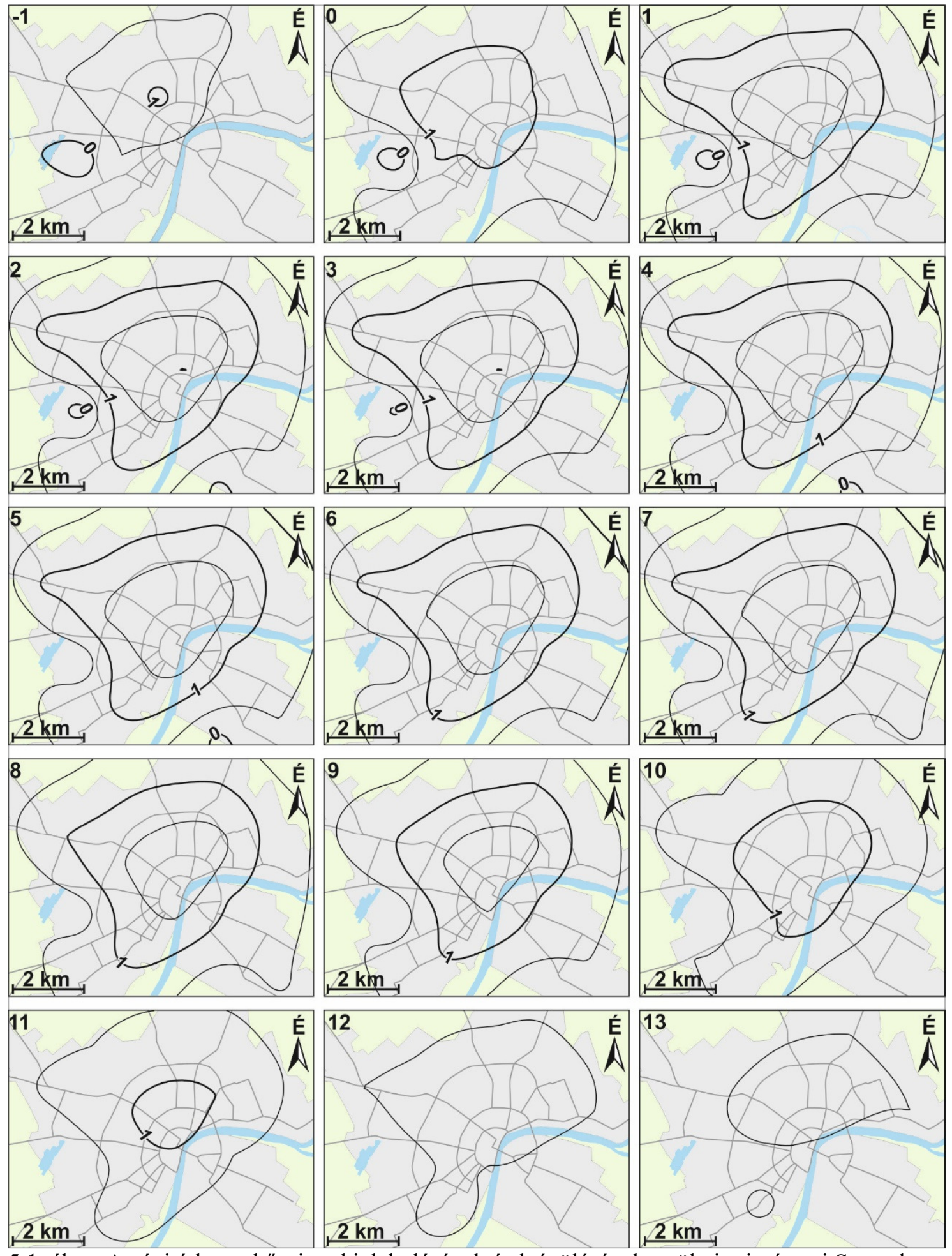

5.1. ábra: Az évi átlagos hősziget kialakulásának és leépülésének területi mintázatai Szegeden a napnyugta előtti 1. órától a napnyugta utáni 13. óráig (2014.06.01-2015.05.31.) (Gál et al., 2016) 

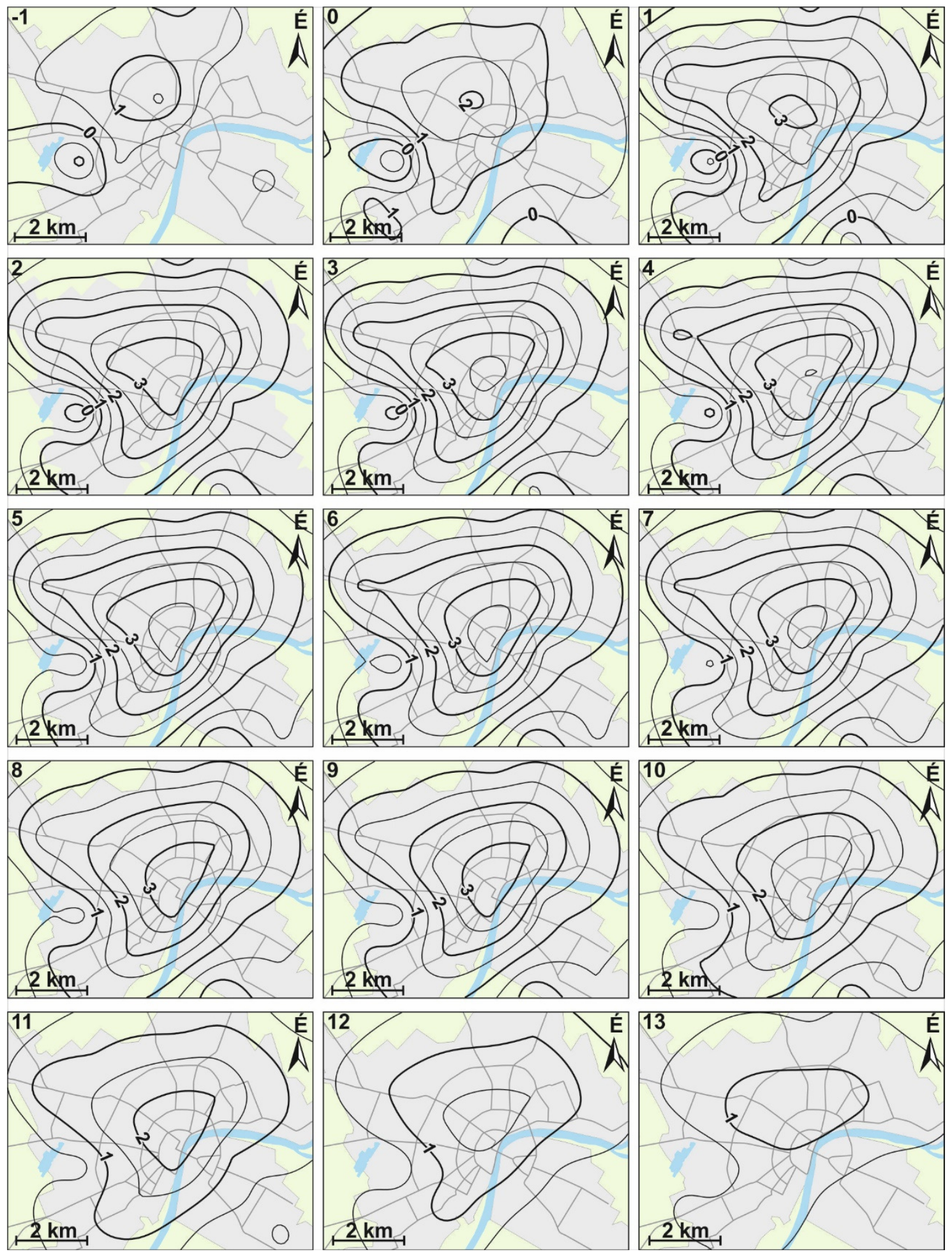

5.2. ábra: Az ideális napokra vonatkozó átlagos hősziget kialakulásának és leépülésének területi mintázatai Szegeden a napnyugta előtti 1. órától a napnyugta utáni 13. óráig (2014.06.012015.05.31.) (Gál et al., 2016) 
Ha a kialakulás számára kedvező időjárási körülményekre koncentrálunk, akkor a hősziget egy sokkal erősebb intenzitást mutat (5.2. ábra). Látható, hogy a mintázat az évi átlagostól eltér és maximális intenzitása már közel $4{ }^{\circ} \mathrm{C}$, ami az előzőekben vizsgált érték majdnem kétszerese (5.1. ábra).

Az UHI ebben az esetben is napnyugtakor kezd el fejlődni, de már ebben az időpontban megjelenik egy $2{ }^{\circ} \mathrm{C}$-os hőmérséklet-különbség (5.2. ábra). A következő órában a $2{ }^{\circ} \mathrm{C}$-os izotermával határolt terület kiterjedése jelentősen megnő, emellett megjelennek a $3{ }^{\circ} \mathrm{C}$ feletti értékek is. Később az UHI területe tovább nő, ami mellett intenzitása is egyre nagyobbá válik. A belvárost $3{ }^{\circ} \mathrm{C}$ feletti különbségek jellemzik, emellett a város többi területén is 1 és $2^{\circ} \mathrm{C}$ közötti eltéréseket találunk. A napnyugta utáni 3. órában az intenzitás már meghaladja a $3,5^{\circ} \mathrm{C}$-ot a városközpontban és egy kis gyengülés után ismét növekedésbe kezd. Az UHI végső gyengülése a +7 . órában kezdődik el, amikor a 3,5 ${ }^{\circ} \mathrm{C}$-os izotermával jellemzett terület kiterjedése csökkenni kezd és a +8 . órában már el is tủnik. Ebben az időpontban a többi izotermával határolt terület is lecsökken, majd a későbbi időpontokban fokozatosan eltünik. A +10 . órától a hősziget leépülése felgyorsul és a +12-13.-ban a hömérséklet-különbségek már minimálisak.

\subsection{A hősziget és a lokális klímazónák kapcsolata egy ideális nap éjszakáján}

Amennyiben az előbb vizsgált térképekhez (5.1. és 5.2. ábra) hasonlóan megszerkesztett mintázatok egyúttal a lokális klímazónák területi eloszlását is tartalmazzák, akkor az UHI izotermái és az egyes LCZ-k elhelyezkedése közötti kapcsolatok könynyen feltárhatók. Ennek megvalósítására az UHI-t fejlődésének meghatározó időpontjaiban ábrázoltam egy ideálisnak tekintett napon (3.8.1. fejezet) a napnyugta előtti 2 órától a napnyugta után 14 óráig 2014. augusztus 29-e éjszakáján (5.3. ábra).

A kezdeti időpontban a hőmérséklet-eloszlás Szegeden közel egységes, a legnagyobb hőmérséklet-különbségek is $1,5^{\circ} \mathrm{C}$ alattiak (5.3. ábra). Napnyugatkor kialakul a klasszikus hőszigetforma, amelynek nagysága a leginkább beépített területeken 1 és $2,5^{\circ} \mathrm{C}$ között alakul. Két órával naplemente után a hősziget még nagyobb intenzitásokat elérve fejlődik, a legmagasabb értékei már $4{ }^{\circ} \mathrm{C}$ felettiek és a központi területeket jellemzik ( $\mathrm{LCZ} 2,3,5$ és 6). A város keleti és déli részein a legtöbb terület hűvösebb marad (LCZ 6 és 9), mivel a hősziget északnyugati irányba terjed ki az LCZ 8-ban megtalálható ipari területek mentén. A nyugati városrészek kissé délebbre fekvő részén szembetűnő a 9-1 állomás környezetében jellemző hideg beáramlás. Az UHI 6 órával napnyugta után éri el maximális erösségét, ekkor már több mint $5{ }^{\circ} \mathrm{C}$ a különbség a belvárosban az LCZ 2, 3 és 5 területén. Az intenzitás napnyugta után 10 órával kezd el kissé csökkeni, amikor a belváros területén már csak $4{ }^{\circ} \mathrm{C}$ fölötti. Később, 14 órával naplemente után, azaz megközelítőleg 3,5 órával napkeltét követően a város és vidék közötti hőmérséklet-különbségek kiegyenlítődnek és minimális, 0 körüli $\left(-0,5\right.$ és $0,5^{\circ} \mathrm{C}$ között) értékekre csökkennek. 

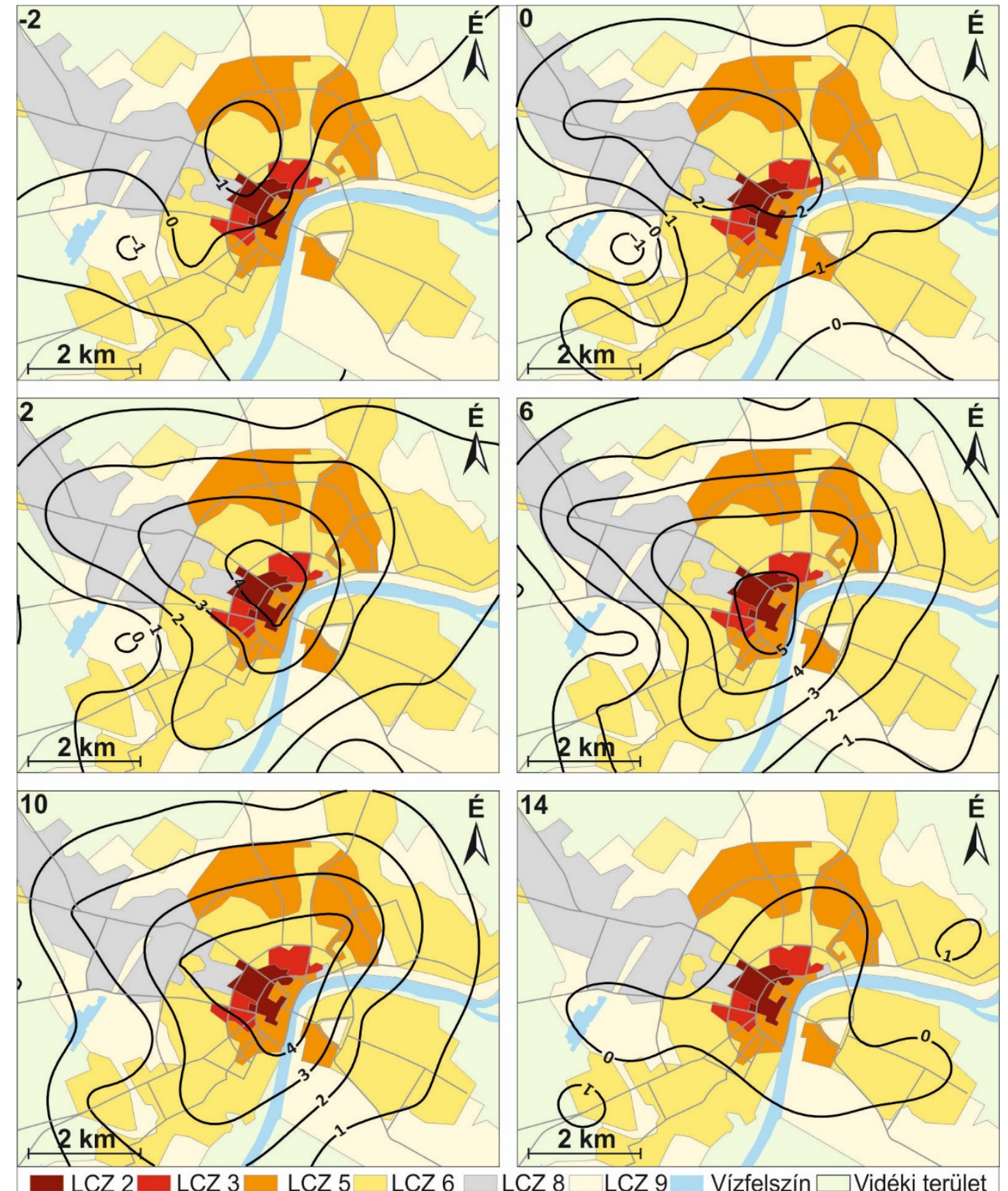

5.3. ábra: A hősziget intenzitás területi mintázatának időbeli alakulása Szegeden napnyugta előtt -2 órától napnyugta után +14 óráig egy ideális nap éjszakáján (2014.08.29-30.) (napnyugta: 17.24 UTC, napkelte: 03.56 UTC) (Unger et al., 2017)

\subsection{A hőmérsékleti gradiens térbeli-időbeli dinamikája}

Ha a városi hőmérsékleti többlet dinamikájának hátterét kívánjuk megismerni, érdemes megvizsgálni a hőmérséklet óránkénti változásának, azaz a hülési/melegedési ütemek területi eloszlását. A szinoptikus skálájú időjárás-változások által generált jelentős hőmérsékleti különbségek hatásainak elkerülése érdekében, a vizsgálatot csak az ideális napok gradiens értékeire terjesztettem ki (3.8.1. fejezet). 

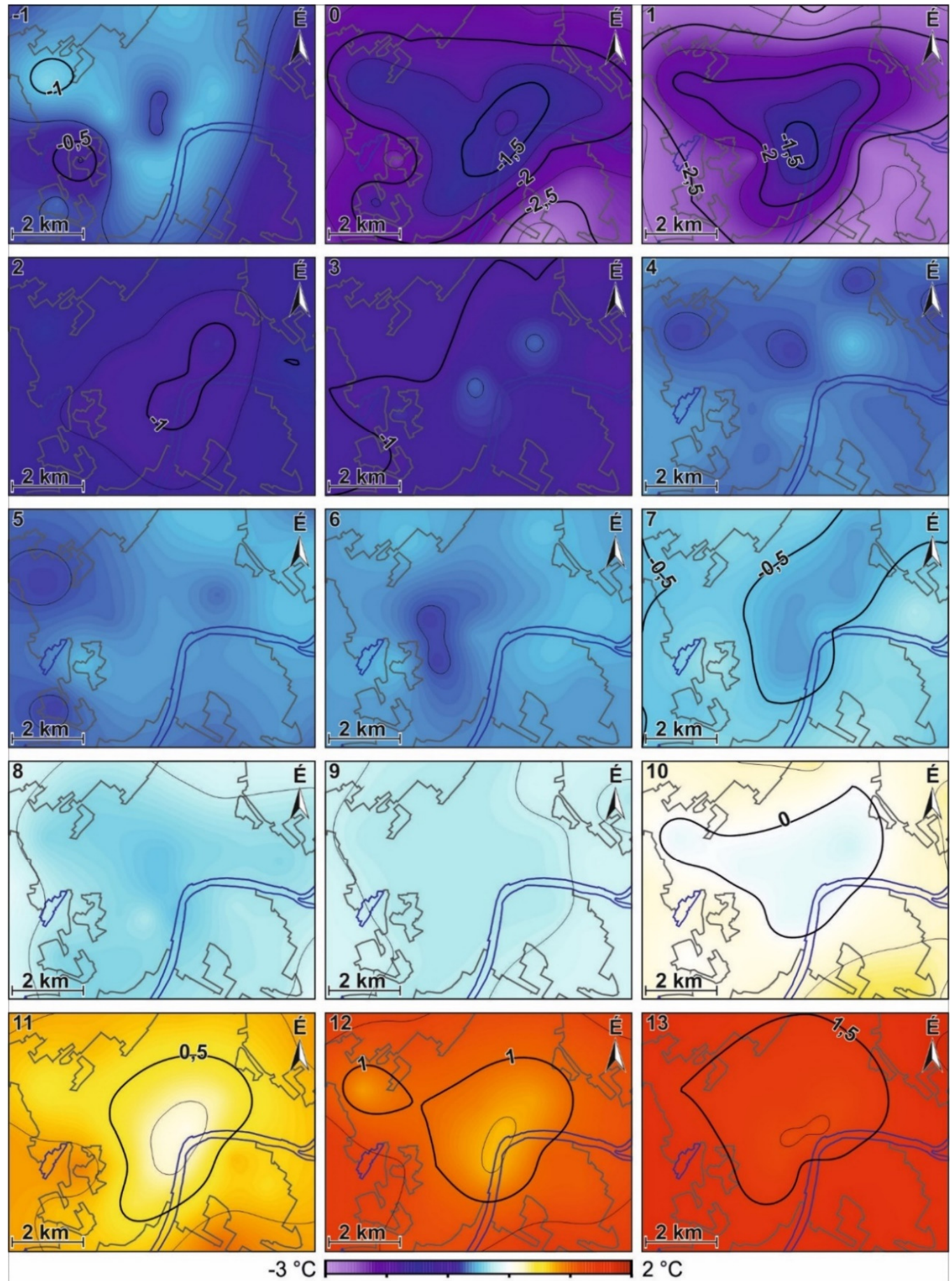

5.4. ábra: Az óránkénti hőmérsékleti gradiens átlagos mintázata ideális napokon napnyugta-1 órától napnyugta+13 óráig Szegeden (2014.06.01-2015.05.31.) (Gál et al., 2016) 
Az 5.4. ábra alapján az éjszaka legintenzívebb hülési folyamata napnyugatkor, illetve utána 1 órával következik be. Ezekben az időszakokban a hőmérsékleti gradiens értéke a városközpontban $-1,5^{\circ} \mathrm{C}$, míg a város legnagyobb részén meghaladja $\mathrm{a}-2{ }^{\circ} \mathrm{C}$-ot. A vidéki területek felé haladva a gradiens értéke egyre csökken, ahol jellemzően $-2,5^{\circ} \mathrm{C}$ alatti, ezzel mutatva e területek gyorsabb hülését. Ezek a különböző értékek okozzák az UHI kifejlődését, amelyek alapján látható, hogy a napnyugta körüli órák a legmeghatározóbbak. A napnyugta utáni 2. és 3. órában a gradiensek abszolútértéke csökken, így már $-1{ }^{\circ} \mathrm{C}$-os érték körül alakulnak, és nem rendelkeznek jellegzetes struktúrával. Az éjszaka további részében az értékek már $0{ }^{\circ} \mathrm{C}$ körüliek és napkeltéig nincs további lényeges változás. Napnyugta után 10 órával egy melegedési folyamat kezdődik el és a gradiensek fokozatosan növekednek. Egy órával később a város legtöbb területén meghaladják a $0,5{ }^{\circ} \mathrm{C}$-ot, míg vidéken ennél nagyobb értékek jellemzők, de még nem érik el az $1{ }^{\circ} \mathrm{C}$ ot. A következő órákban a melegedés mértéke eléri az 1 , majd a $1,5^{\circ} \mathrm{C}$-ot a város területén is.

Az előzőekben is bebizonyosodott, hogy az UHI képződésének hátterében a város és vidék eltérő hülési/melegedési dinamikája áll (Oke, 1987). Ennek mintájára vizsgálható a városon belüli eltérések kialakulásának háttere, azaz a különböző beépített és természetes felszínek eltérö hőmérsékleti gradiensének hatása. A következőkben az egyes lokális klímazónák gradienseinek éjszakai változását vizsgálom a 3.8.1. fejezetben ismertetett különböző időszakok szerint külön-külön taglalva. Mellettük, az összefüggések eredményesebb bemutatása érdekében az egyes LCZ-k D-1 állomásától vett értékeinek menetét is ábrázolom (5.5. ábra).

Az évi átlagos értékek esetében a hőmérséklet-különbségek az éjszaka elején minimálisak, majd a következő órákban gyorsan változnak a hőmérsékleti gradiensek függvényében (5.5a. ábra). A legnagyobb hülési ütem a napnyugta időpontjára esik, ahol az LCZ 9 és D esetében $-1,5^{\circ} \mathrm{C}$, míg az LCZ 2 és 3-ban $-1{ }^{\circ} \mathrm{C}$ körüli értékek találhatók (5.5b. ábra). Az LCZ 6 és 8 értékei e sürün beépített és természetes felszínek között helyezkednek el. Látható, hogy nincs számottevő különbség a gradiensek között, így éves átlagban nem jelenik meg jelentős intenzitású hősziget. Ebben az időszakban a maximális intenzitás elérése napnyugta után 2 órával történik, amelynek mértéke LCZ-től függően 1 és $2{ }^{\circ} \mathrm{C}$ között alakul és a gradienseknek megfelelően az LCZ 2 és 3-ban a legnagyobb. A maximumértékek elérése után csak elenyésző mértékü csökkenés figyelhető meg, amely a gradiensek kis növekedéséhez köthetö, ami valamennyi zónánál közel azonos mértékü. Napnyugta után 8 órával gyorsul fel ez a növekedés, amikor a zónák gradiensei szétválnak, így a hőmérséklet-különbségek csökkenése eléri a kezdeti értékeket.

A vizsgált év ideális napjainak átlagában a gradiensek között már számottevő különbség jelenik meg: az LCZ 9 és $\mathrm{D}$ esetében mértéke majdnem eléri a $-3{ }^{\circ} \mathrm{C}$-ot, míg az LCZ 2, 3 és 5-nél csupán alig haladja meg a $-1{ }^{\circ} \mathrm{C}$-ot (5.5d. ábra). Ennek köszönhetően egyrészt intenzívebb hőszigetet fedezhetünk fel, valamint ezáltal a zónák hőmérsékletkülönbségei is jobban elkülönülnek és egy megközelítőleg $3{ }^{\circ} \mathrm{C}$-os maximális eltérés jelenik meg közöttük (5.12c. ábra). Napnyugta után 1 órával az LCZ 2 és 3 területén már elég magas, $3{ }^{\circ} \mathrm{C}$-os intenzitás tapasztalható, amely a következő 6 órában tovább növekszik, megközelítve a $4{ }^{\circ} \mathrm{C}$-ot. Valamennyi zóna hasonló tendenciát mutat az LCZ 8 kivételével, ahol a csökkenés már a maximum elérése után elkezdődik. Az LCZ-k gradiensei napnyugta után 4 órától már gyakorlatilag együtt futnak, szétválásuk a +9 . és +10 . óra körül (napfelkeltekor) kezdődik meg, amikor is az LCZ 9 és D melegszik gyorsabban, míg legkevésbé a tölük kb. $0,5^{\circ} \mathrm{C}$-kal lemaradó LCZ 2 és 3. Ennek a folyamatnak köszönhetően a zónák hősziget-intenzitásának értékei gyorsabban csökkennek és a +14 . órában valamennyi zóna közel azonos értéket mutat. 


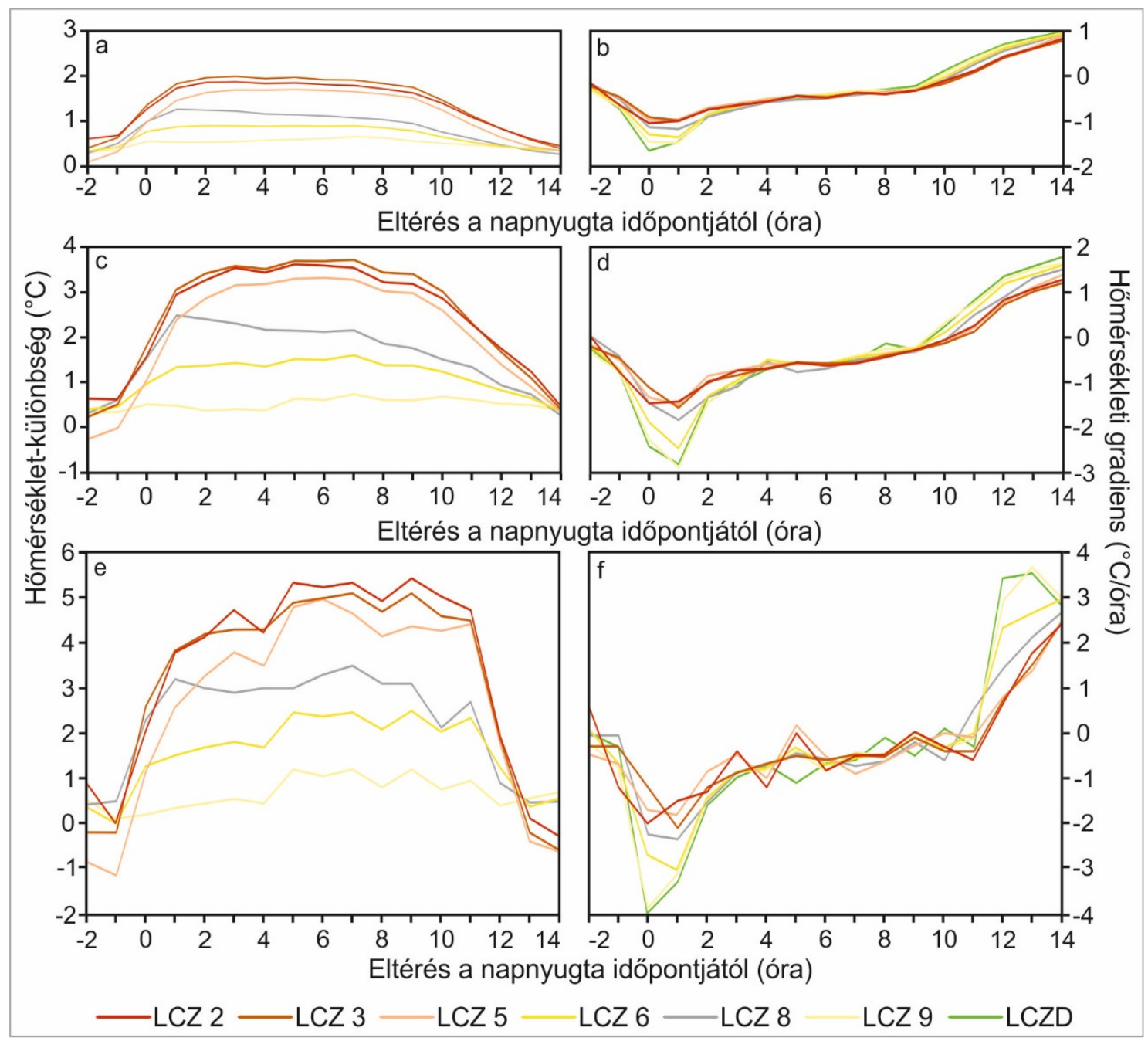

5.5. ábra: Az egyes LCZ-k hőmérséklet-különbségei a D-1 állomástól (a, c ,e), illetve a hozzájuk tartozó óránkénti hőmérsékleti gradiens (b, d, f) (a, b: évi átlag; c, d: ideális napok átlaga; e, f: 2014.08.29-30.) (Skarbit et al., 2017)

A 2014.08.29-i éjszakán, amikor a hősziget kialakulásához különösen kedvező körülmények uralkodtak, látható, hogy az LCZ 9 és D hőmérsékletei igen jelentősen csökkennek, hiszen gradiensük napnyugatkor a $-4{ }^{\circ} \mathrm{C}$-ot közelíti (5.5f. ábra). A többi zónában a legnagyobb csökkenés 1 órával később jelenik meg, ami az LCZ 6 esetében kiemelkedő, hiszen eléri a $-3{ }^{\circ} \mathrm{C}$-ot. Az LCZ 2, 3 és 5 gradiensei abszolút értékben a legkisebbek, értékei -1 és $-2^{\circ} \mathrm{C}$ között alakulnak. Napnyugta után 1 órával már egy erős hősziget alakul ki, amelynek intenzitása az LCZ 2 és 3-ban már ebben az órában eléri a $4{ }^{\circ} \mathrm{C}$-ot (5.5e. ábra). Ezt követően - kisebb csökkenésektől eltekintve - az intenzitás tovább nő és az éjszaka folyamán meghaladja az $5{ }^{\circ} \mathrm{C}$-ot. Jelentősebb változás a napnyugta utáni 11. órában következik be, amikor a kültéri zónák hőmérsékleti gradiensei hirtelen megemelkednek, meghaladva a $3{ }^{\circ} \mathrm{C}$-ot. Ekkor a nagyobb beépítettséggel rendelkező zónák lassabban melegszenek fel, ezzel elősegítve a hősziget leépülését. 


\section{A lokális klímazónák felszínhőmérséklet-különbségei}

A lokális klímazónákra jellemző felszínhőmérséklet értékek megállapítása a Lelovics-Gál-módszerrel kialakított zónák és a mintaterület (3.11. ábra) átfedése alapján készült a 2008. augusztus 12-i és 14-i mérések alapján (3.8.2. fejezet) a teljes területre, illetve csak a földfelszínre (3.3. fejezet).

\subsection{A teljes területre vonatkozó felszínhőmérsékletek vizsgálata}

A 6.1a. ábra a földfelszínre és az épületekre együtt mutatja be a felszínhőmérséklet értékek gyakoriságát lokális klímazónák szerint augusztus 12-én, amely szerint a leggyakoribb értékek $21-25^{\circ} \mathrm{C}$ között fordulnak elő. A többi zónával összehasonlítva az LCZ 9 adatainak eloszlása eltér, mivel nem rendelkezik kiemelkedő gyakorisággal jellemzett értékkel. A vidéki terület esetében 2 csúcs figyelhető meg, egy kisebb $15^{\circ} \mathrm{C}$-nál, valamint egy nagyobb $21^{\circ} \mathrm{C}$-nál és értékeinek tartománya az LCZ 9-hez közelít. A második csúcshoz hasonló gyakorisági értékkel $(0,16)$ emelkedik ki az LCZ 3 is $22{ }^{\circ} \mathrm{C}$-nál. Az LCZ 2, 5 és 8 leggyakoribb hömérséklet értékei magasabbak, rendre 23,24 és $25^{\circ} \mathrm{C}$. Az LCZ 6 leggyakoribb értékei 20-21 ${ }^{\circ} \mathrm{C}$ között helyezkednek el, megközelítőleg 0,13-os gyakorisági értékkel. Magasabb, $28{ }^{\circ} \mathrm{C}$-nál nagyobb felszínhőmérsékletek leginkább az LCZ 8-ban jelennek meg. Megállapítható, hogy a nagyobb gyakoriságok leginkább a beépített zónákban jellemzők, ezen belül a kompaktabb zónákban egy adott felszínhőmérsékleti érték körüli $1{ }^{\circ} \mathrm{C}$-os tartomány fordul elő leginkább. Az egyre nyitottabb zónák felé haladva a gyakorisági görbék kevésbé koncentrálódnak egy érték köré, azaz kevésbé jellemezhetők egy tipikus értékkel. Emellett érdemes megjegyezni, hogy a legmagasabb hőmérsékleti értékek nem a kompakt zónákban a leggyakoribbak, hanem az LCZ 8-ban, ahol az alacsonyabb épületek lapos teteje könnyen felmelegszik és a vízzáró felszínborítás aránya is nagyobb. Továbbá, az LCZ 5 területén is a kompakt zónákéval hasonló gyakorisággal fordul elő magasabb hőmérsékleti érték.

Augusztus 14-én az értékek kis mértékben eltérnek az előzőekben leírtaktól (6.1b. ábra). A legfontosabb különbségnek az tekinthető, hogy a magasabb hőmérsékletek nagyobb gyakorisággal fordulnak elő, aminek oka, hogy a vizsgált időszakban folyamatosan melegedő tendencia jellemezte az időjárási körülményeket, ami kihatott a felszínhőmérsékletre is (3.16. ábra). Ennek köszönhetően a zónák többségénél már a $26-30{ }^{\circ} \mathrm{C}$ közötti értékek a leggyakoribbak. Az LCZ 2, 35 és 8 legtöbbször előforduló értékei egyaránt $28-29^{\circ} \mathrm{C}$ között helyezkednek el, és ennek mértéke zónától függően 0,12-0,18 között alakul. Látható, hogy a magasabb gyakorisági értékek a kompakt zónákat jellemzik, azon belül is az alacsonyabb beépítést (LCZ 3). Az LCZ 9 és a vidéki terület között valamelyest átmenetet képező LCZ 6 legkiemelkedőbb értékei ebben az időszakban meghaladják a $26{ }^{\circ} \mathrm{C}$-ot, 0,16-os gyakorisággal. Az LCZ 9 ezen az estén is alacsony gyakorisági értékekkel rendelkezik, amelyek széles skálán mozognak, így továbbra sincs kiemelhető tipikus felszínhőmérséklet. További különbség az előzően vizsgált naphoz képest, hogy a vidéki terület esetében már csak egy csúcs van, ami $23{ }^{\circ} \mathrm{C}$ körül található, előfordulása hasonló mértékü $(0,16)$, mint a városi zónák többségének gyakorisági értékei. Tehát magasabb hőmérsékleti körülmények között a külterületre is egy adott szükebb hömérsékleti tartomány a legjellemzőbb, amely kb. $5{ }^{\circ} \mathrm{C}$-kal alacsonyabb a kompakt zónákhoz képest. 


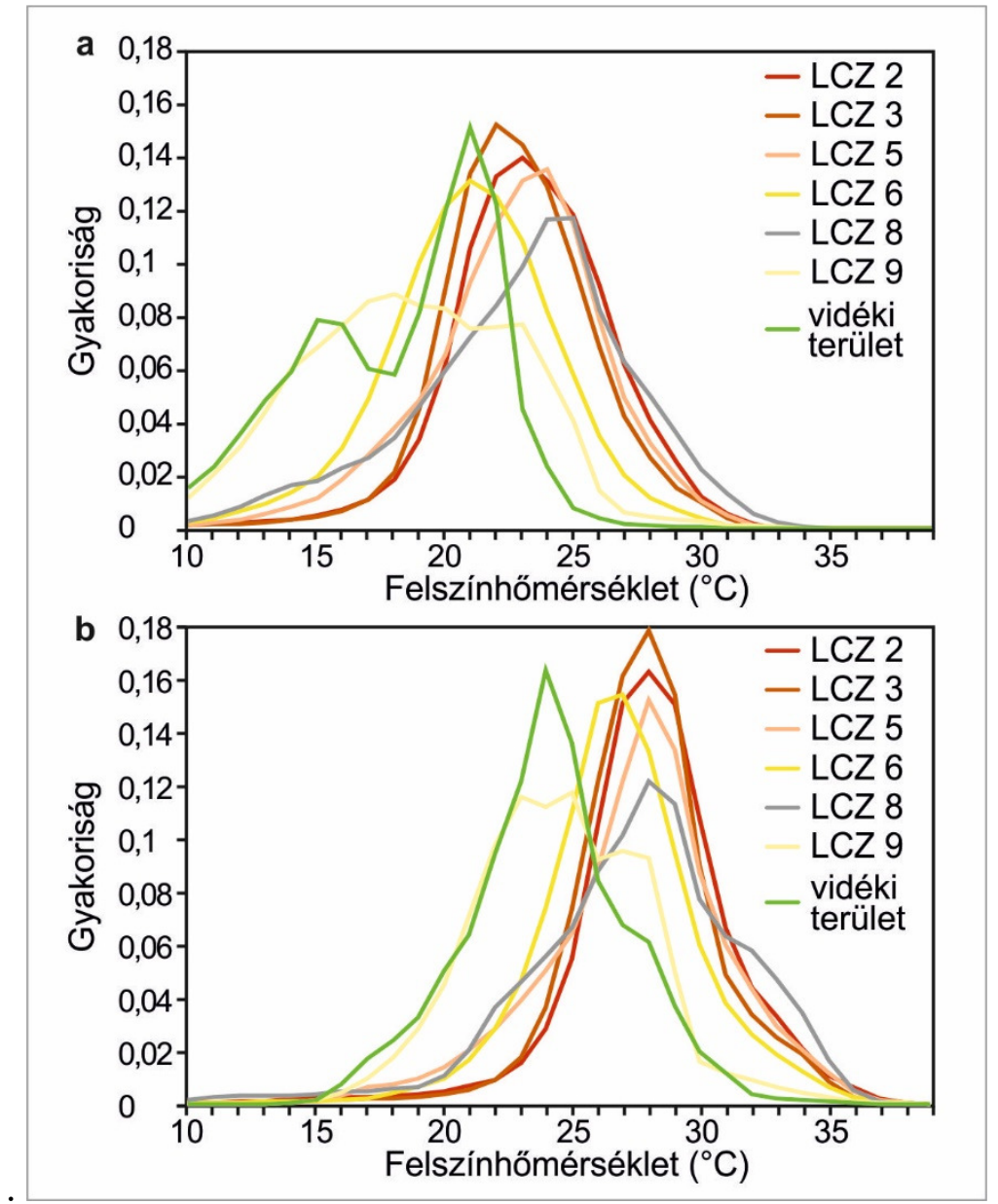

6.1. ábra: A felszínhőmérsékleti értékek gyakorisága lokális klímazónánként 2008. (a) augusztus 12-én és (b) augusztus 14-én 19 UTC-kor a teljes vizsgált területen (Skarbit et al., 2015)

\subsection{Közvetlenül a földfelszínre vonatkozó értékek vizsgálata}

Amennyiben az épületeket elhanyagoljuk és csak a földfelszínre (utcaszintre) vonatkozó értékeket elemezzük, akkor az eredmények hasonlók, csupán néhány eltérés fedezhető fel (6.2. ábra). Augusztus 12-én (6.2a. ábra) az LCZ 2 gyakorisági csúcsa $26{ }^{\circ} \mathrm{C}$-nál helyezkedik el, és 0,16-os értékével észrevehetően kiemelkedik a többi zóna közül. Az LCZ 8 esetében is a $26^{\circ} \mathrm{C}$ körüli értékek a leggyakoribbak, csak kisebb mértékben $(0,12)$, de a $30^{\circ} \mathrm{C}$ fölötti hőmérsékletek már ebben a zónában fordulnak elő a legtöbbször. Jelen esetben az LCZ 3 és 5 gyakorisági görbéje szinte azonos, és a legtöbb érték $23-25^{\circ} \mathrm{C}$ közötti. Az LCZ 6 és a vidéki terület esetében a $21^{\circ} \mathrm{C}$-os érték a leggyakoribb, de eloszlásuk eltérö, mivel $23{ }^{\circ} \mathrm{C}$ fölötti hőmérsékletek az LCZ 6-ban többször fordulnak elö. A vidéki területen itt is megjelenik a kettős csúcs és az LCZ 9 gyakorisági értékeinek alakulása is hasonló a teljes területhez képest. Összeségében elmondható, hogy csak a földfelszínt tekintve, a magasabb hömérsékleti értékek - a teljes területhez képest - valamennyi zónában gyakoribbak. Ekkor már a kompakt, közepes beépítés legtöbbször elöforduló értéke a legmagasabb, azaz ebben a zónában tekinthető a legmelegebbnek a felszín. Megállapítható, hogy a felszínhőmérsékleti értékek zónák szerinti nagyságsorrendje a klímazónák megkülönböztetésének léghőmérsékleten alapuló koncepcióját követik.

Csak a földfelszínt vizsgálva is magasabbak az augusztus 14-i értékek az előző vizsgált naphoz képest (6.2b. ábra). A lokális klímazónák szerinti eloszlások hasonlóak a 
teljes terület értékeihez, de kisebb eltérések megfigyelhetök. Ezek közül a legfontosabbnak az tekinthető, hogy már az LCZ 2-ben gyakoribbak a $30^{\circ} \mathrm{C}$ közeli felszínhőmérséklet értékek, mint az LCZ 3-ban, a hosszúhullámú sugárzás nagyobb arányú csapdába esése miatt. Azaz, az épületek közötti felszín a magasabb épületekkel jellemzett zóna esetében melegebb. Ez abban is megmutatkozik, hogy a magasabb értékek csak a 33-35 ${ }^{\circ} \mathrm{C}$ közötti szük tartományban és kis mértékben gyakoribbak az LCZ 8-ban, mint az LCZ 2-ben és $35^{\circ} \mathrm{C}$ fölött ismét az utóbbit jellemzik leginkább.

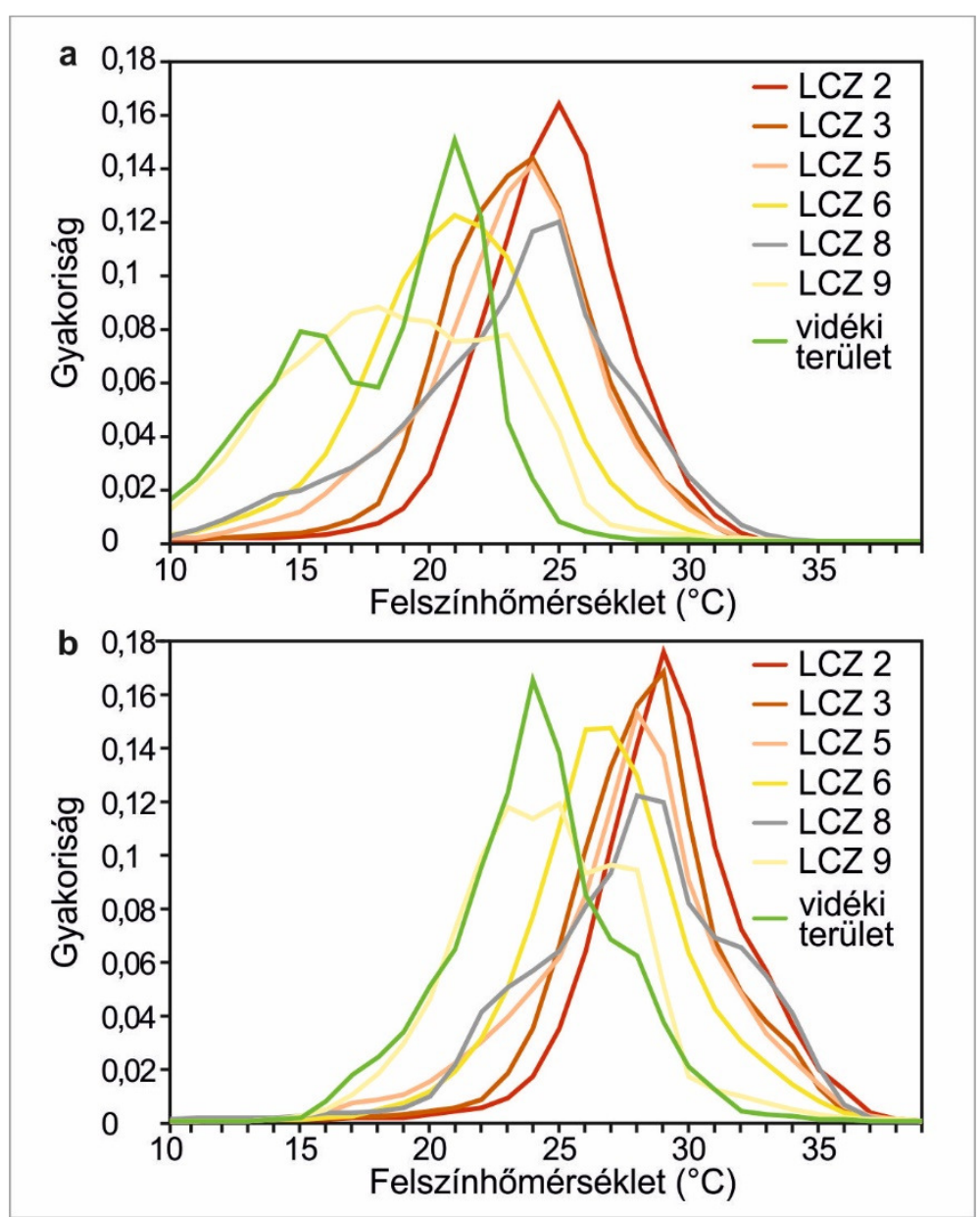

6.2. ábra: A felszínhőmérsékleti értékek gyakorisága lokális klímazónánként 2008. (a) augusztus 12-én és (b) augusztus 14-én 19 UTC-kor a földfelszínen (Skarbit et al., 2015)

Dobozdiagramok segítségével az LCZ-k felszínhőmérsékleti sajátosságai tovább elemezhetők (6.3. ábra), amelyek szerint nem az LCZ 2 mutatja a legnagyobb maximum értékeket, de mindkét nap mediánja ( 26 és $29^{\circ} \mathrm{C}$ ), valamint az alsó és felső kvartilisek ennél a zónánál a legmagasabbak. Az LCZ 3 értékei hasonlóan alakulnak, a statisztikai mutatók csak 1-2 ${ }^{\circ} \mathrm{C}$-kal alacsonyabbak, azaz a kompakt zónákban jellemzők leginkább a magas felszínhőmérsékletek. Látható, hogy az LCZ 2 és 3 leggyakoribb értékeinek tartománya szükebb, mint az értékek nagyságában csak kevéssé lemaradó LCZ 5 esetében. Az LCZ 6 statisztikai mutatói az LCZ 5-höz képest kisebbek, azaz a zóna alacsonyabb hőmérsékleti értékekkel rendelkezik, de eloszlása hasonló mértékü. Szélesebb tartományon mozognak az LCZ 8-ra jellemző hőmérsékletek, mivel a felső kvartilis és a medián megközelíti az LCZ 2 értékeit, míg az alsó kvartilis az LCZ 6-hoz áll a legközelebb. Az LCZ 9 és a vidéki terület értékeinek eloszlása a legszélesebb a zónák közül és ezekben a legkisebbek a statisztikai mutatók. Tehát a kompakt zónák felől a természetes felszínek 
felé haladva egyre kevésbé gyakoribb egy adott felszínhőmérséklet körüli érték, azaz nagyobb lesz az LCZ-n belüli változékonyság. Az eredmények alapján látható, hogy az értékek nagyságának sorrendjében is tükröződik a klímazónák tulajdonságainak hatása a felszín termikus reakcióira. Ha a két vizsgált napot kívánjuk összehasonlítani, akkor megállapítható, hogy valamennyi zónában minden statisztikai mutató magasabb a második napon, emellett az értékek koncentráltabb eloszlást mutatnak, amely leginkább a vidéki területnél látványos.

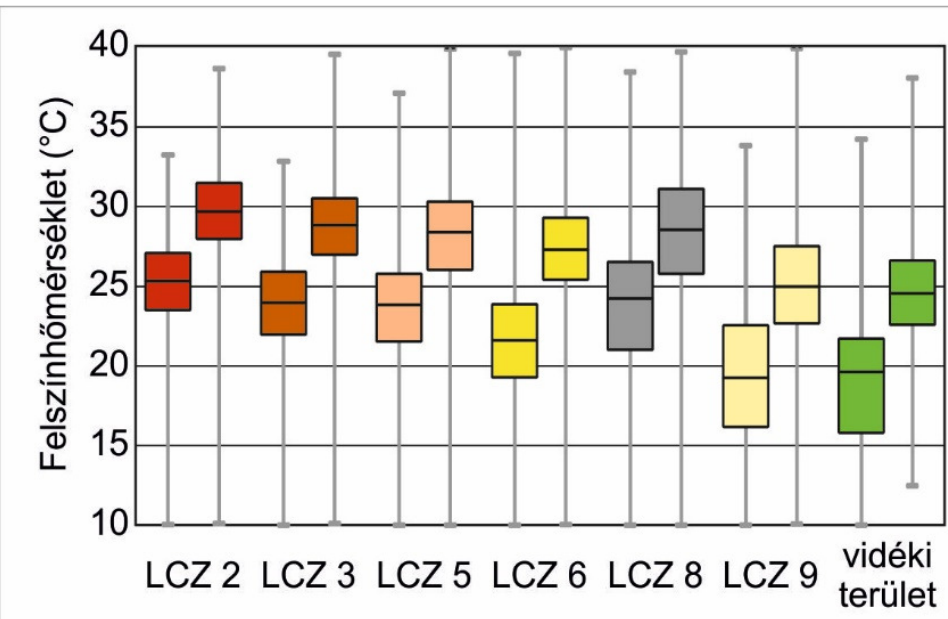

12.14. 12.14. 12.14. 12.14. 12.14. 12.14. 12.14.

6.3. ábra: A felszínhőmérsékleti értékek dobozdiagramjai lokális klímazónák szerint a földfelszínen 2008. augusztus 12-én és 14-én 19 UTC-kor (Skarbit et al., 2015)

Az LCZ osztályozás ilyen irányú kiterjesztésére e vizsgálat előtt nem találunk példákat, azonban később már jelentek meg a zónák és a felszínhőmérséklet kapcsolatát elemző további kutatások. Geletič et al. (2016b) a legmagasabb felszínhőmérsékletet szintén a kompakt zónákban állapították meg az LCZ 10 (nehézipar) mellett Brno-ban (Csehország). A legkisebb értékek itt is a külterületen adódtak, amit LCZ-k szerint vizsgálva az LCZ A-t, illetve G-t jelentette a párologtató felszín túlsúlya miatt. Cai et al. (2017) szintén a beépített zónák természetestől magasabb felszínhőmérsékleteit állapította meg két kínai város esetében. A legnagyobb értkéket az LCZ 1 és 10 esetén kapták, míg a Szegeden is előforduló zónák közül az LCZ 5 értékei a kompakt zónáknál magasabbnak adódtak, ami valószínüsíthetően a régiónként eltérő felszínborítási tulajdonságok következménye. A külterület valamennyi zónájának értéke kisebbnek adódott a beépítetteknél, amelye közül szintén LCZ A-ban volt a legalacsonyabb. 


\section{A lokális klímazónák humánkomfort viszonyainak elemzése}

A humánkomfort viszonyok elemzésénél a vizsgált időszak tovább bővült az elemzés kezdetekor rendelkezésre álló leghosszabb periódusra (közel 3 év). Ekkor az egyes lokális klímazónákra leginkább reprezentatív állomások (2-1, 3-1, 5-2, 6-8, 9-2 és D-1 (3.3. ábra)) adatai jelentették az adatbázist, kivéve az LCZ 8-at, amit az ott fellépő adathiányok indokoltak (3.8.3. fejezet).

\section{1. Évi és évszakos átlagértékek}

A PET (3.4. fejezet) átlagos évi és évszakos értékeit tekintve a legnagyobb értékek az LCZ 2 és 3, míg a legkisebbek az LCZ D-ben fordulnak elő mind a délutáni, mind az esti időszakban (7.1. táblázat). Az értékek a sürün beépített, kompakt zónáktól haladva csökkennek a nyitottabb, természetesebb felszínborítás felé napszaktól és évszaktól függetlenül, vagyis a hőstressz mérséklésének szempontjából a legkedvezőbb beépítési típusok az LCZ 6 és 9. A zónák közötti legnagyobb különbség nyáron jelenik meg, amikor $\triangle \mathrm{PET}_{\mathrm{LCZ}} 2-\mathrm{D}$ értéke délután $3,6^{\circ} \mathrm{C}$, este pedig $3,5^{\circ} \mathrm{C}$. A többi évszakot tekintve a napnyugta utáni különbségek kisebbek, mint a napközbeni értékek. A délutáni különbségek közül az őszi $\left(\triangle \mathrm{PET}_{\mathrm{LCZ} 2-\mathrm{D}}=2,4{ }^{\circ} \mathrm{C}\right)$, míg éjszaka a téli $\left(\triangle \mathrm{PET}_{\mathrm{LCZ} 2-\mathrm{D}}=2,1^{\circ} \mathrm{C}\right)$ a legkisebb.

7.1. táblázat: A zónánként kiválasztott állomások évi és évszakos átlag PET értékei kora délután és este Szegeden (2014.06.01-2017.01.31.) (Unger et al., 2018)

\begin{tabular}{|c|c|c|c|c|c|c|c|}
\hline \multirow{2}{*}{ napszak } & \multirow{2}{*}{ évszak } & \multicolumn{6}{|c|}{ LCZ } \\
\cline { 2 - 8 } & & $\mathbf{2}$ & $\mathbf{3}$ & $\mathbf{5}$ & $\mathbf{6}$ & $\mathbf{9}$ & $\mathbf{D}$ \\
\hline \multirow{3}{*}{ kora délután } & tavasz & 19,3 & 18,9 & 18,5 & 18,3 & 17,6 & 16,0 \\
\cline { 2 - 8 } & nyár & 35,0 & 34,6 & 34,2 & 34,1 & 32,8 & 31,4 \\
\cline { 2 - 8 } & ösz & 20,3 & 20,2 & 20,2 & 19,7 & 18,9 & 17,9 \\
\cline { 2 - 8 } & tél & 3,5 & 3,6 & 3,4 & 3,3 & 1,9 & 0,7 \\
\cline { 2 - 8 } & évi & 19,0 & 18,8 & 18,6 & 18,3 & 17,3 & 16,2 \\
\hline \multirow{5}{*}{ este } & tavasz & 8,6 & 8,5 & 8,0 & 7,4 & 7,1 & 6,0 \\
\cline { 2 - 8 } & nyár & 18,7 & 18,9 & 18,0 & 17,5 & 16,5 & 15,2 \\
\cline { 2 - 8 } & ösz & 9,8 & 9,8 & 9,4 & 8,6 & 8,4 & 7,6 \\
\cline { 2 - 8 } & tél & $-2,0$ & $-2,1$ & $-2,3$ & $-2,7$ & $-2,8$ & $-4,1$ \\
\cline { 2 - 8 } & évi & 8,3 & 8,3 & 7,8 & 7,2 & 6,8 & 5,8 \\
\hline
\end{tabular}

A hőérzeti kategóriák LCZ-k szerinti gyakoriságát tekintve, általánosságban megállapítható, hogy a „hideg” kategóriák (hideg, hüvös, enyhén hüvös) a kevésbé beépített zónákban, míg a „meleg” kategóriák (enyhén meleg, meleg, forró) a beépített zónákban gyakoribbak (7.2. táblázat). A neutrális kategória leggyakrabban a kompakt zónákban jelenik meg a nyári évszak estéjén és értéke magasabb, mint $40 \%$. Délután több neutrális és hüvösebb időszak van a kevésbé beépített zónákban (ősz kivételével). Így napközben a legkedvezőbb zónák a kevésbé beépítettek (LCZ 6, 9 és D), de este a helyzet az ellenkezőjére fordul, ekkor a belvárosi területek (LCZ 2 és 3) kedvezőbbek a kültéri tevékenységekhez. 
7.2. táblázat: Az egyes LCZ-k hőérzeti kategóriáinak gyakorisága a különböző évszakokban és napszakokban Szegeden (2014.06.01-2016.11.30.) (Unger et al., 2018)

\begin{tabular}{|c|c|c|c|c|c|c|c|c|}
\hline \multirow{2}{*}{ évszak } & \multirow{2}{*}{ napszak } & \multirow{2}{*}{$\begin{array}{c}\text { PET } \\
\text { kategória }\end{array}$} & \multicolumn{6}{|c|}{ LCZ } \\
\hline & & & 2 & 3 & 5 & 6 & 9 & D \\
\hline \multirow{11}{*}{ 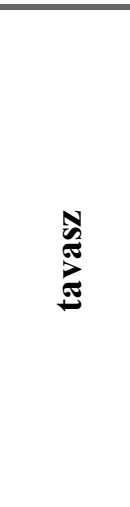 } & \multirow{6}{*}{$\begin{array}{c}\text { kora } \\
\text { délután }\end{array}$} & hideg & 1,0 & 1,4 & 1,5 & 1,3 & 2,4 & 4,3 \\
\hline & & hüvös & 6,9 & 7,8 & 8,2 & 9,4 & 12,2 & 13,9 \\
\hline & & e. hüvös & 23,1 & 24,3 & 26,0 & 25,3 & 25,2 & 26,8 \\
\hline & & neutrális & 23,3 & 22,9 & 21,1 & 22,3 & 23,3 & 26,4 \\
\hline & & e. meleg & 34,3 & 33,5 & 33,9 & 32,3 & 29,4 & 23,5 \\
\hline & & meleg & 11,4 & 10,1 & 9,3 & 9,4 & 7,5 & 5,1 \\
\hline & \multirow{5}{*}{ este } & hideg & 21,9 & 22,1 & 24,6 & 28,4 & 30,7 & 36,8 \\
\hline & & húvös & 27,6 & 27,4 & 27,3 & 25,9 & 25,2 & 26,8 \\
\hline & & e. hüvös & 29,7 & 29,8 & 30,3 & 30,4 & 30,6 & 27,8 \\
\hline & & neutrális & 18,9 & 18,9 & 16,8 & 14,7 & 13,2 & 8,5 \\
\hline & & e. meleg & 1,9 & 1,8 & 1,0 & 0,6 & 0,3 & 0,1 \\
\hline \multirow{11}{*}{ 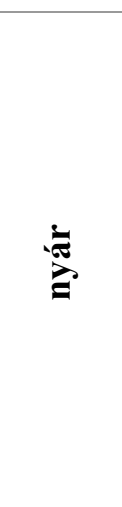 } & \multirow{6}{*}{$\begin{array}{c}\text { kora } \\
\text { délután }\end{array}$} & hüvös & 0 & 0 & 0 & 0 & 0 & 0,1 \\
\hline & & e. hüvös & 0,9 & 0,8 & 0 & 0,8 & 1,6 & 2,4 \\
\hline & & neutrális & 3,9 & 3,8 & 4,8 & 5,3 & 7,4 & 10,6 \\
\hline & & e. meleg & 14,5 & 16,0 & 17,0 & 16,1 & 18,1 & 20,7 \\
\hline & & meleg & 60,9 & 61,6 & 60,7 & 61,4 & 58,6 & 55,7 \\
\hline & & forró & 19,8 & 17,8 & 17,5 & 16,4 & 14,3 & 10,5 \\
\hline & \multirow{5}{*}{ este } & hüvös & 9,9 & 9,2 & 13,0 & 15,1 & 21,8 & 30,3 \\
\hline & & e. hüvös & 26,7 & 26,1 & 29,6 & 32,2 & 35,6 & 38,1 \\
\hline & & neutrális & 40,4 & 41,1 & 39,2 & 38,7 & 32,5 & 27,5 \\
\hline & & e. meleg & 21,7 & 22,3 & 17,5 & 13,6 & 9,9 & 4,1 \\
\hline & & meleg & 1,3 & 1,3 & 0,7 & 0,4 & 0,2 & 0 \\
\hline \multirow{11}{*}{ 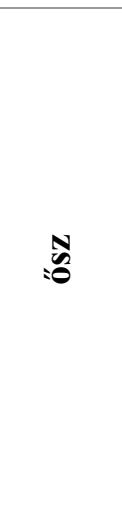 } & \multirow{6}{*}{$\begin{array}{c}\text { kora } \\
\text { délután }\end{array}$} & hideg & 5,1 & 4,7 & 5,4 & 5,5 & 7,1 & 7,8 \\
\hline & & húvös & 9,0 & 7,8 & 7,6 & 7,8 & 10,3 & 12,4 \\
\hline & & e. hüvös & 21,9 & 22,6 & 22,0 & 22,8 & 22,4 & 23,2 \\
\hline & & neutrális & 27,9 & 29,3 & 29,2 & 29,0 & 29,1 & 26,9 \\
\hline & & e. meleg & 26,3 & 26,3 & 26,6 & 25,9 & 22,7 & 21,7 \\
\hline & & meleg & 9,8 & 9,3 & 9,2 & 9,0 & 8,4 & 8,0 \\
\hline & \multirow{5}{*}{ este } & hideg & 17,8 & 18,5 & 20,4 & 23,2 & 24,6 & 27,5 \\
\hline & & hüvös & 28,3 & 28,7 & 28,7 & 28,4 & 28,8 & 31,1 \\
\hline & & e. húvös & 31,7 & 30,8 & 30,4 & 29,9 & 28,4 & 26,3 \\
\hline & & neutrális & 18,2 & 18,4 & 17,8 & 16,4 & 16,5 & 14,0 \\
\hline & & e. meleg & 4,0 & 3,6 & 2,7 & 2,1 & 1,7 & 1,1 \\
\hline
\end{tabular}

7.2. Az ősz, tavasz és nyár átlagos tendenciái

A 7.1.-7.3. ábrákat tekintve, a PET alakulásának görbéi két csoportban helyezkednek el: az LCZ 2, 3, 5 és 6 (továbbiakban beépített LCZ-k) vonalai együtt mozognak, míg az LCZ 9-et és D-t (továbbiakban természetes LCZ-k) alacsonyabb értékek határozzák meg. Ezeknek a csoportoknak közös jellemzöjük, hogy a beépített LCZ-k főként vízzáró felszínnel rendelkeznek, míg a természetes felszínekre az áteresztő borítás a jellemző.

Az átmeneti évszakok (tavasz: 7-15. dekád, ősz: 25-33. dekád) termikus viszonyait kora délután a 7.1. ábra, este a 7.2. ábra mutatja be. A tavaszt fokozatosan javuló, míg az őszt fokozatosan romló értékek jellemzik mindkét napszakban. Az LCZ-k sorrendje megnevezésüket követi, a délutáni 29-31 dekád közötti időszaktól eltekintve, amikor az LCZ 3 megelőzi az LCZ 2-t. A tavaszi délutánokon PET értékei az enyhén hűvös és az enyhén meleg kategóriák $\left(9,7-27,7^{\circ} \mathrm{C}\right)$ között változnak a beépített LCZ-k esetében. A 
természetes zónákban kora tavasszal egy kategóriával alacsonyabban (hüvös) helyezkednek el az értékek (7.1a. ábra). Az évszak valóban kedvező része (neutrális) a 9-10. dekádtól (március vége - április eleje) kezdődik és májusig elejéig tart.

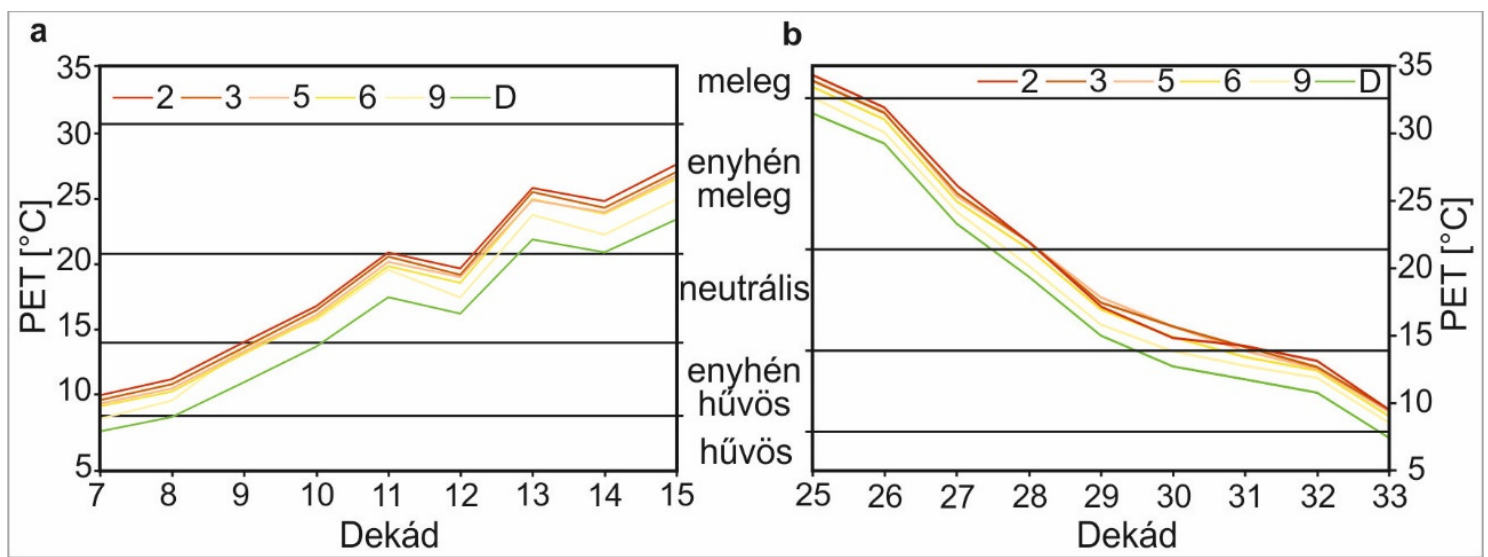

7.1. ábra: A zónánként kiválasztott állomások 10 napos PET átlagainak időbeli változása az egyes PET kategóriákon belül kora délután, tavasszal (a) és ősszel (b) Szegeden (Unger et al., 2018)

Az ősz magas termikus viszonyokkal indul, ugyanis az első PET-ek a meleg kategóriában elhelyezkedve magasabbak (megközelítik a $35^{\circ} \mathrm{C}-\mathrm{t}$ ), mint a tavasz utolsó értékei (7.1b. ábra). Fontos megjegyezni, hogy a kedvező kategóriák (enyhén hüvös-enyhén meleg) tartományai ebben az évszakban szélesebbek, illetve a meleg hőérzet $2^{\circ} \mathrm{C}$-kal magasabban kezdődik (3.2. táblázat). Az évszak kellemes része a természetes felszínek esetében a 29-30. dekádig, míg a beépített területeken a 30. dekádig tart (október közepevége). Látható, hogy az évszak végén az LCZ D már a hüvös kategóriába esik $\left(<7,9^{\circ} \mathrm{C}\right)$.

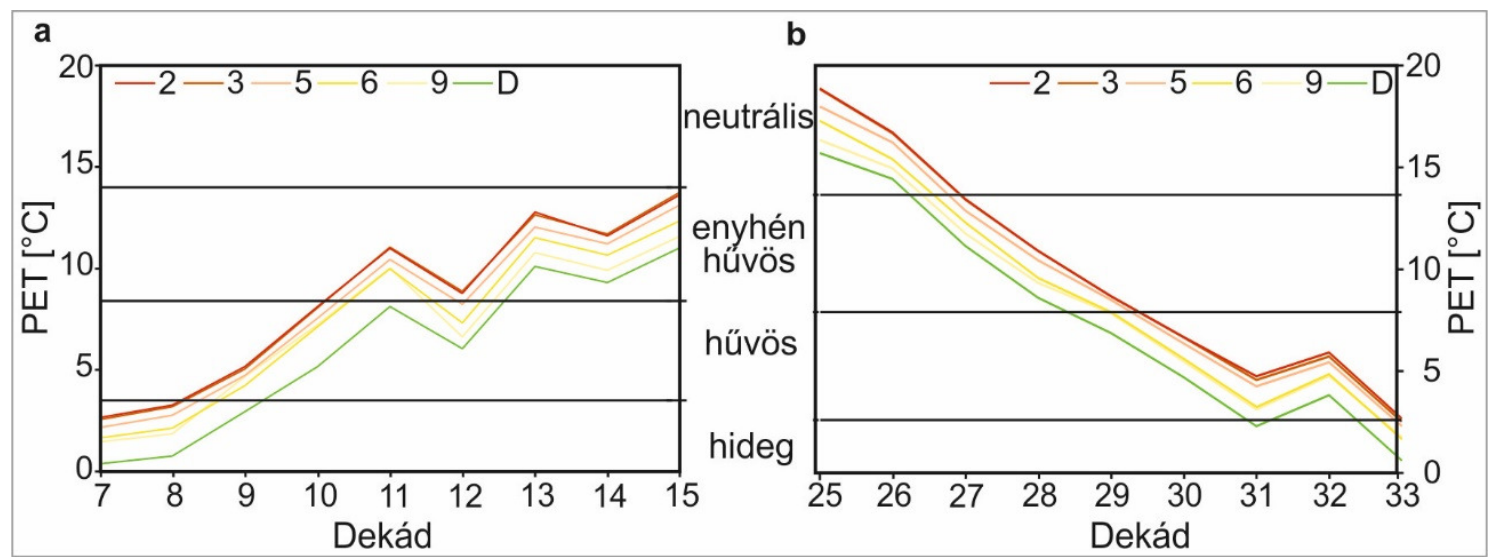

7.2. ábra: A zónánként kiválasztott állomások 10 napos PET átlagainak időbeli változása az egyes PET kategóriákon belül este, tavasszal (a) és ősszel (b) Szegeden (Unger et al., 2018)

Az esti PET menetek alakja nagyon hasonló a délutáni értékekhez mind a két átmeneti évszakban, de az értékek két kategóriával alacsonyabbak és $12-18^{\circ} \mathrm{C}$ között alakulnak (7.2. ábra). Tavasszal a kültéri tevékenységekhez kedvező körülmények a 10. dekádnál (március közepe) már megjelennek a beépített zónákban, míg a természetesekben 3 héttel később kezdődnek és az értékek az évszak végéig az enyhén hüvös kategóriában maradnak (7.2a. ábra). Ebben a napszakban is nagyobb értékekkel kezdődik az ösz, az első PET-ek (neutrális kategória) magasabbak, mint a tavaszt záróak. Ez a különbség a beépített zónákban $4,9-5,1^{\circ} \mathrm{C}$, míg a természetes zónákban $4,7-4,8^{\circ} \mathrm{C}(7.2 \mathrm{~b}$. ábra). A természetes zónákban szeptember végétől (28. dekád), a beépítettekben október elejétől (29. dekád) az időjárási körülmények már nem kedvezőek a kültéri tevékenységekhez. Ezek 
alapján általánosságban elmondható, hogy a kedvező kültéri termikus komfort viszonyok időszaka hosszabb a beépített zónákban, mint a természetes felszínűek esetében.

Nyáron délután (16-24 dekádok között) a négy beépített zóna megközelítőleg együtt mozog, közöttük maximum $1{ }^{\circ} \mathrm{C}$ különbség van és sorrendjük az LCZ számukat követik (7.3a. ábra). A természetes zónák ezektöl elmaradnak, az LCZ $92{ }^{\circ} \mathrm{C}-\mathrm{kal}$, míg az LCZ D további $1{ }^{\circ} \mathrm{C}$-kal. A legnagyobb különbségek az LCZ 2 és D között vannak (pl. $\triangle \mathrm{PET}_{\mathrm{LCZ} 2-\mathrm{D}}=4,6^{\circ} \mathrm{C}$ a 20 . dekádban). Valamennyi 10 napos átlag a meleg hőérzeti kategóriában van az LCZ D-t leszámítva (enyhén meleg) a 18. dekádban (június közepe), amikor egy hirtelen, minden zónára kiterjedő csökkenés figyelhető meg. Ebben az idöszakban az Atlanti-óceán felöl gyakran érkezik nedves légtömeg, amely lehüléssel kísért heves esőzéseket eredményez (Medárd). A 21-23. dekádok között (július vége-augusztus) PET értékei $\left(>37^{\circ} \mathrm{C}\right)$ megközelítik a forró kategóriát a legtöbb beépített zónában (LCZ 2, 3, 5). A legnagyobb értékek valamennyi zónában július végén jelennek meg $\left(\mathrm{PET}_{\mathrm{LCZ} 2}>38^{\circ} \mathrm{C}, \mathrm{PET}_{\mathrm{LCZ} \mathrm{D}}>34^{\circ} \mathrm{C}\right.$ ), amelyek az emberi szervezetet jelentős hőterhelésnek teszik ki. Ezután lassú visszaesés következik, amely augusztus végén felgyorsul.

A nyáresti értékeket tekintve PET növekvő és csökkenő tendenciái a délután időszakhoz hasonlók, de két kategóriával alacsonyabbak (neutrális, enyhén hüvös) (7.3b. ábra). A délutánhoz hasonlóan, a 21. dekádtól kezdődő hülés mértékének különbségei eltéréseket eredményeznek a sürün beépített és természetes zónák között (pl. $\triangle \mathrm{PET}_{\mathrm{LCZ} 3-\mathrm{D}}=4,8^{\circ} \mathrm{C}$ a 21. dekádban). Ebben az esti időszakban csak az LCZ 2 és 3 értékei változnak szorosan együtt a neutrális zónában, elkülönülve $\left(2-3^{\circ} \mathrm{C}\right)$ a másik két beépített zónától. Ez alól kivétel a 18. dekád, amikor a többi beépített zóna csak 0,5$1{ }^{\circ} \mathrm{C}$-os különbséggel tér el. Az LCZ D PET értékei az egész évszak alatt az enyhén hűvös kategóriába esnek. Következésképpen, este valamennyi beépített zóna alkalmas a kültéri szabadidős tevékenységekre.

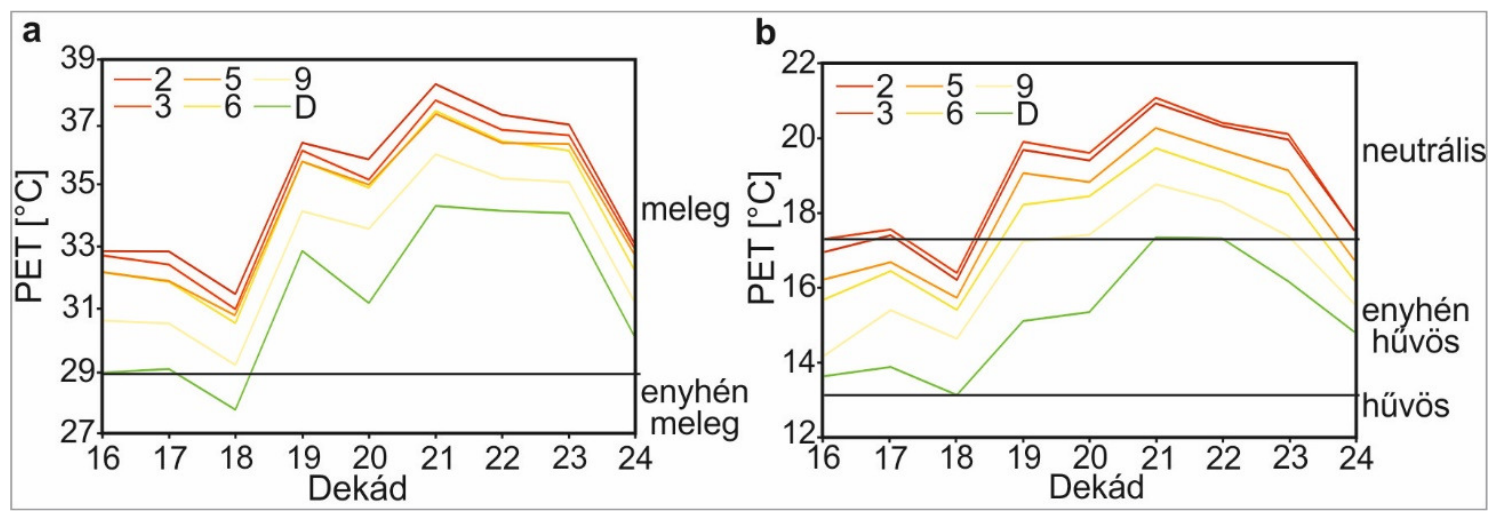

7.3. ábra: A zónánként kiválasztott állomások 10 napos PET átlagainak időbeli változása az egyes PET kategóriákon belül nyáron, kora délután (a) és este (b) Szegeden (Unger et al., 2018)

\subsection{A 2015.08.12-16. közötti höhullámos időszak vizsgálata}

A PET értékek napi változása hasonló volt a vizsgált időszak 4 napjában (7.4. ábra). A napközbeni órákban (9-10 és 17-18 UTC között) az értékek a forró kategóriába esnek egy néhány ${ }^{\circ} \mathrm{C}$-os zónák közötti különbséggel (legnagyobb: $\triangle \mathrm{PET}_{\mathrm{LCZ}} 2-\mathrm{D}=2,6{ }^{\circ} \mathrm{C}$ ), így komoly höterhelést jelentenek a város valamennyi részén a napsütötte órákban. A legnagyobb értékek az LCZ 2-ben jelentek meg $\left(>45^{\circ} \mathrm{C}\right)$, amelyek augusztus 15-én már az $50{ }^{\circ} \mathrm{C}$-ot is megközelítik. Napnyugta körül (17.50 UTC) az értékek rövid idő alatt két kategóriát estek vissza az enyhén meleg kategóriáig valamennyi LCZ esetén és elkülönülnek a zónák eltérő hủlési üteme miatt. Ennek köszönhetően a zónák közötti különbségek megnőttek és az éjszaka $\triangle \mathrm{PET}_{\mathrm{LCZ} 2-\mathrm{D}}$ értéke néhány időpontban már nagyobb volt, 
mint $6{ }^{\circ} \mathrm{C}$. Az éjszakai órákban az LCZ 2, 3, és 5 a neutrális, míg az LCZ 9 és D az enyhén hüvös kategóriába estek az utolsó éjszakát leszámítva, amikor egy intenzív advekció átkeverte a levegöt a zónák között, csökkentve a lehülés mértékét a természetesebb zónákban. Ebben az időszakban a PET napi változása nagy volt; a nappal és éjszaka közötti különbség meghaladta a $30^{\circ} \mathrm{C}$-ot a négy beépített zónában (LCZ 2: $31,2{ }^{\circ} \mathrm{C}$, LCZ 3: $30,6^{\circ} \mathrm{C}$, LCZ 5: $31,1^{\circ} \mathrm{C}, \operatorname{LCZ} 6: 33,2^{\circ} \mathrm{C}$ ), míg a természetes LCZ-kben ez az érték már a $35^{\circ} \mathrm{C}$-ot is elérte, a nap folyamán öt hőérzeti kategóriát átívelve.

A 7.4. ábra alapján a 24 órás időszak egyértelmủen két részre osztható: hőterheléssel jellemzett és anélküli időszakokra. A város teljes lakossága kb. 10 órától kezdődően 6-8 órán keresztül rendkívül nagy hőstressznek volt kitéve (forró kategória) és emellett még 5 órán keresztül egy ennél kisebb mértékü, de ugyanúgy jelentős hőterheléssel jellemzett időszak (meleg kategória) tartott. Ennek megszünése csak 19-20 UTC után következett be (enyhén meleg, neutrális kategória) és reggelig, 8 UTC-ig tartott. Csak az LCZ 9 és D esetében tapasztalhattunk egy nagyon kismértékü, neutrális alatti hőérzetet éjszaka, ugyanis itt néhány órában az enyhén hüvös kategória volt a jellemzö.

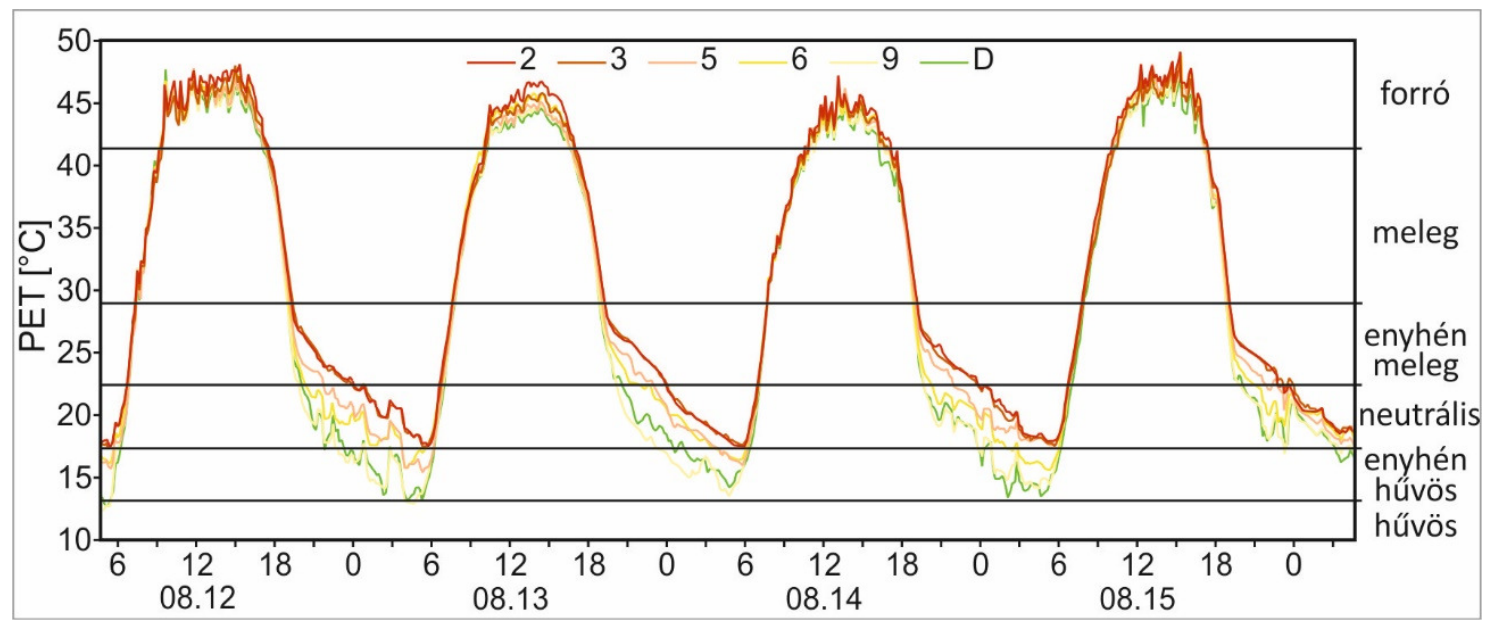

7.4. ábra: A zónánként kiválasztott állomások PET értékeinek időbeli változása (UTC szerint) az egyes PET kategóriákon belül 2015. augusztus 12-16. között Szegeden (Unger et al., 2018)

A fenti eredményeik alapján - azaz a kültéri emberi hőérzetet évszakonként és a nap különböző részein vizsgálva - az LCZ-k sorrendjére vonatkozóan, megállapítható, hogy a zónák számát követi és megfelel létrehozásuk eredeti koncepciójának, amely a zónák közötti léghőmérsékletbeli különbségekre koncentrált. A sorrend azt mutatja, hogy napközben a leginkább kedvező zónák a kevésbé beépítettek, míg este ez az ellenkezőjére vált és a kültéri tevékenységeknek inkább a város belső területei kedveznek. Milosevič et al. (2016) szintén egy hőhullámos időszak viszonyait vizsgálták Újvidéken (Szerbia). Napközben a legmegterhelőbb beépített zónának az LCZ 5, éjszaka pedig az LCZ 2 bizonyult, míg egész napra nézve a legkedvezőbbnek az LCZ A. Az LCZ A-t leszámítva, valamennyi (beépített) zóna PET értéke magasabb az LCZ D-ben tapasztaltétól este és az éjszakai órákban, a legnagyobb különbség szintén LCZ 2 esetében volt. Napközben az LCZ D PET értékei adódtak a legmagasabbnak, ami esetünkben nem volt jellemző és az esetleges szélsebességbeli különbségeknek tulajdonítható. Geletič et al. (2018) hasonló eredményeket állapítottak meg modellszimulációk alapján, noha más bioklimatikus index (HUMIDEX) használatával Brnoban. Legmegterhelőbb zónáknak a leginkább beépítettek adták meg: LCZ 2, 3, 5, 8 és 10, míg legkomfortosabbnak az LCZ 9-et és a külterületi zónákat. 


\section{Klímaindexek módosulásának előrejelzése}

A következőkben bemutatott vizsgálat hat klímaindex (3.7. fejezet) változását modellezi az 1981-2010 referencia időszakban mérési, valamint a 2021-2050 és 2071-2100 jövőbeli időszakokban klímamodell adatok alapján (3.5. és 3.8.4. fejezet). A modellezett eredmények mérési adatokkal történő összevetése az 1999-2010 időszakban valósulhatott meg, hiszen a referencia időszakon belül ekkor álltak már rendelkezésre két mérési pontról adatok a vizsgált területen (külterület: D-1 állomás, belterület: 5-1 állomás (3.3. ábra)). A lokális léptékű szimulációk a MUKLIMO_3 modell alapján készültek (3.6. fejezet), az 1999-2010 validációs időszak, illetve a 30-éves időszakok átlagértékeit a cuboid módszer alkalmazásával kaptam meg (3.7. fejezet). A mintaterületet a 3.5. ábra mutatja be, amely alapján a vizsgált klímaindexek LCZ-k szerinti pontos átlagértékeinek kiszámítása is megtörtént (3.1.2. fejezet). A klímaindexek közül kettő-kettő kapcsolódik a napi maximum- és minimum-, valamint egy adott időponti hőmérséklethez, így ilyen csoportosításban mutatom be a 30-éves időszakok szerinti átlaguk, illetve változásaik jellemzőit.

\subsection{Nyári és hőségnapok}

A nyári és hőségnapok a napi maximum-hőmérséklethez köthetők, míg előbbinél ez az érték a 25 , addig az utóbbinál már a $30^{\circ} \mathrm{C}$-ot haladja meg. A nyári napok száma a vizsgált területen az 1981-2010-es referencia időszakban 14 és 107 között változik (8.1a. ábra). A város környezetében, azaz a külterületen általánosságban a 40-50 nap közötti értékek a tipikusak. A külterület eltérő felszínborítása jól tükröződik az eredményekben, elsősorban a 40 nap alatti értékek szembetünők, amelyek a vízfelszíneket jelölik, de a környező tavaknál a 20-at sem éri el ez a szám. Emellett alacsonyabb értékek fordulnak elő a sürü, fás növényzettel rendelkező területeken a Tisza vonala mentén, valamint elszórva a külterület több részén is. Általánosságban, a beépített terület határát az 50 nap feletti értékek jelölik ki. A 3.5 ábrát is tekintve az LCZ 9 tipikus értékei 50-60 közöttiek, az LCZ 5 és 6-ba átlépve ez az értéke már meghaladja a 60, több területen a 70 napot. A modell az LCZ 5 és 8 esetében 80 nap fölötti értékeket ad, de ebben a zónákban egy nagyobb területen a városközpont felől északnyugati irányba haladva a 90 felettiek is megjelennek. A legtöbb nyári nap az LCZ 2 és 3 területén adódik, ezekben a zónákban 100 fölötti értékeket találunk (8.1a. ábra).

A 2021-2050 időszak vizsgálatánál (8.1b., c. ábra) a két szcenárió között jelentkezik különbség, de annak mértéke nem jelentős. Szembetünő a külterületen bekövetkező változás, ahol a nyári napok száma már 50 fölötti, csupán a vízfelszínek és a fás növényzet mutatnak ennél kisebb értékeket. A város határát a 60 nap fölötti értékek jelölik ki, ennek a határvonalnak a területi kiterjedése nem változik meg jelentősen a közeljövőben egyik szcenárió szerint sem. A beépített területen a legjelentősebb változás és szcenáriók közötti különbség a 70 és afölötti napok eloszlásában jelentkezik. A 70 fölötti értékek a Tisza bal oldali részén foglalnak el a referencia időszakhoz képest nagyobb területet, amely az RCP8.5 esetében (8.1c. ábra) szinte az egész beépített területre kiterjed. A város északkeleti részén, az LCZ 6-ban 80 fölötti lesz a nyári napok száma (3.5. ábra). Az LCZ 5 esetében a 90 nap fölötti értékek egyre nagyobb területen történő megjelenése a szembetűnő, föként a zóna északi részén az RCP8.5-nél. Míg a 100 nap fölötti értékek területi kiterjedése az RCP4.5 szerint alig változik (8.1b. ábra), addig az RCP8.5 alapján már az LCZ 8 belvároshoz közeli részein is megjelenik. Ennél az utóbbi, pesszimistább szcenáriónál már a 110 nap feletti értékek is megjelennek, méghozzá az LCZ 2 és 3 legbelsőbb területein. 


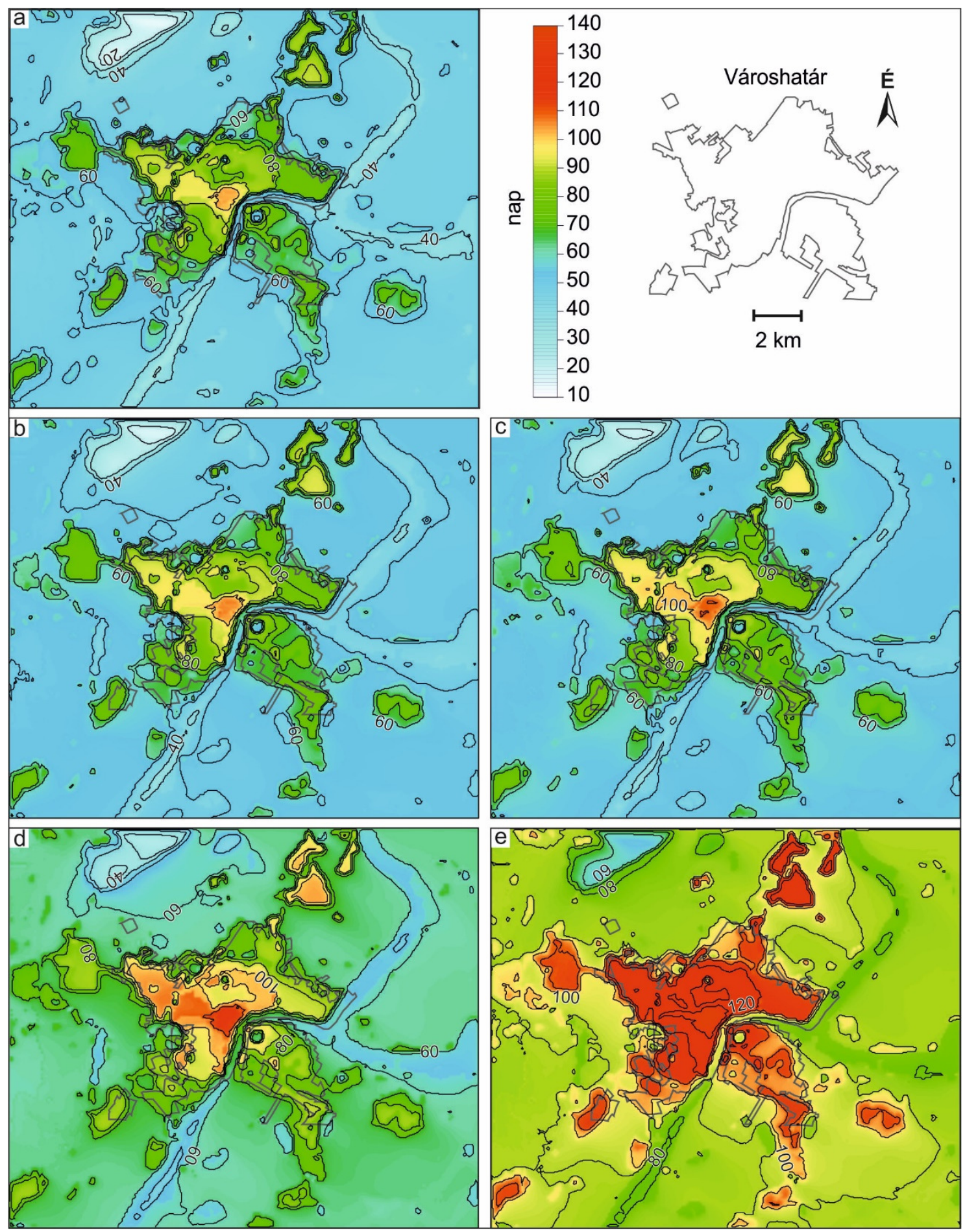

8.1. ábra: A nyári napok $\left(\mathrm{T}_{\max } \geq 25^{\circ} \mathrm{C}\right)$ számának modellezett területi eloszlása Szegeden és környezetében mérési és klímamodell adatok alapján (a: 1981-2010; b: 2021-2050, RCP4.5; c: 2021-2050, RCP8.5; d: 2071-2100, RCP4.5; e: 2071-2100, RCP8.5)

A 2071-2100 időszakban (8.1d., e. ábra) tovább folytatódik a napok számának növekedése, ami az RCP8.5-nél megdöbbentő mértékü, nem csak a referencia, hanem a 20212050 időszakhoz hasonlítva is. Látható, hogy a két szcenárió között igen jelentős a különbség, ugyanazon a területen 20-30 nap közötti eltérést találhatunk. A külterületen az RCP4.5 szerint a nyári napok száma 60-70 közötti, ami az RCP8.5 esetében már 80-100 között alakul, azaz már itt is meghaladhatja a 3 hónapot. Érdemes megjegyezni, hogy míg előbbinél nem jelentkezik nagyobb kiterjedésü 10 napos eltérés a külterületen, addig 
utóbbinál a beépített terület határát a 90 nap feletti értékek veszik szélesen körbe. A beépített területen az LCZ 9-nél 70 feletti a napok száma az RCP4.5-nél, míg a 8.5-nél ez már 100 (3.5. ábra). Ahol az első szcenáriónál 80 nap fölötti értékeket találunk ott az RCP8.5-nél ez a szám 110 fölötti, ezek az értékek leginkább az LCZ 6 területén a jellemző. Az LCZ 5 és 8 esetében, míg az optimistább szcenárió is 100 napnál nagyobb értékeket ad, addig ez az érték a pesszimistább szcenáriót tekintve már 120. A század végén szintén a kompakt zónákban jelenik meg a legtöbb nyári nap, ami az RCP4.5-nél 110, az RCP8.5-nél 130 napot jelent. Utóbbi esetében a 130 fölötti értékek nem csak az LCZ 2 és 3 területét érintik, hanem az LCZ 8-ban is megjelennek (8.1e. ábra).

A nyári napok LCZ-k szerinti területi átlagát és annak változását vizsgálva az összehasonlítás során, látható, hogy a természetes felszíneket érinti a legnagyobb növekedés valamennyi időszakban (8.1. táblázat). Ennek relatív mértéke a 2021-2050 időszakban csak 10\% körül alakul, azonban a század végén az RCP8.5 szerint a nyári napok száma majdnem a kétszeresére nő. A beépített zónák közül a legnagyobb változás a kevésbé beépítetteket érinti, az LCZ 9 és 6 esetében a századvégi változás már rendre $68 \%$ és $56 \%$. Az LCZ 5 és 8 értékeinek változása szinte azonos és 2071-2100-ban sem éri el az 50\%-ot. A legkisebb változás a legnagyobb értékeket mutató kompakt zónákat érinti, amelynek mértéke a század közepén a $10 \%$-ot sem éri és a század végén is csak az RCP8.5 szerint közelíti meg a 40\%-ot.

8.1. táblázat: A nyári napok $\left(\mathrm{T}_{\max } \geq 25^{\circ} \mathrm{C}\right)$ lokális klímazónák szerinti átlagos száma az egyes időszakok és szcenáriók szerint, valamint relatív eltérésük az 1981-2010 időszaktól

\begin{tabular}{|l|c|c|c|c|c|c|c|}
\hline $\begin{array}{l}\text { Időszak } \\
\text { (szcenárió) }\end{array}$ & LCZ 2 & LCZ 3 & LCZ 5 & LCZ 6 & LCZ 8 & LCZ 9 & $\begin{array}{c}\text { LCZ A, } \\
\text { B és D }\end{array}$ \\
\hline $\mathbf{1 9 8 1 - 2 0 1 0}$ & 98 & 93 & 84 & 71 & 84 & 60 & 46 \\
\hline $\mathbf{2 0 2 1 - 2 0 5 0}$ & 101 & 96 & 87 & 75 & 87 & 63 & 50 \\
(RCP4.5) & $3 \%$ & $3 \%$ & $4 \%$ & $6 \%$ & $4 \%$ & $5 \%$ & $9 \%$ \\
\hline $\mathbf{2 0 2 1 - 2 0 5 0}$ & 105 & 99 & 91 & 78 & 90 & 66 & 52 \\
$\mathbf{( R C P 8 . 5 )}$ & $7 \%$ & $7 \%$ & $8 \%$ & $10 \%$ & $7 \%$ & $10 \%$ & $13 \%$ \\
\hline $\mathbf{2 0 7 1 - 2 1 0 0}$ & 112 & 107 & 99 & 87 & 98 & 75 & 61 \\
(RCP4.5) & $14 \%$ & $15 \%$ & $18 \%$ & $23 \%$ & $17 \%$ & $25 \%$ & $33 \%$ \\
\hline $\mathbf{2 0 7 1 - 2 1 0 0}$ & 133 & 128 & 121 & 111 & 121 & 101 & 88 \\
(RCP8.5) & $36 \%$ & $38 \%$ & $44 \%$ & $56 \%$ & $44 \%$ & $68 \%$ & $91 \%$ \\
\hline
\end{tabular}

A hőségnapok $\left(\mathrm{T}_{\max } \geq 30^{\circ} \mathrm{C}\right)$ száma az előző indexhez képest jóval alacsonyabb, az 1981-2010-es referencia időszakban a teljes területet tekintve 0-33 között változik (8.2a. ábra). A külterületen jellemzően 10 nap alatt alakul csak elszórva, néhány kisebb területen haladja meg ezt az értéket. A beépített területen a hőségnapok száma 10 fölötti, csak a város egyes részein (főként a legészakabbra fekvő területeken) nem éri el ezt az értéket. A város külső részein (LCZ 6 és 9 területén) az értékek nem mennek 15 nap fölé, csak a városközponthoz közelebb elhelyezkedő LCZ 6-nál haladják meg ezt a számot (3.5. ábra). Az LCZ 8 és 5 esetében a hőségnapok száma meghaladja a 20-at, a kompakt zónák területén pedig a 30 -at is.

A 2021-2050 időszakban mindkét szcenárió esetében a napok száma a belvárosban megközelíti a 40-et (8.2b., c. ábra). Mindkét esetben a korábbi határvonalak területi kiterjedésének növekedésében érzékelhető a változás. Ebben az időszakban már a város teljes területén 10 nap felettiek az értékek. Míg az LCZ 9-ben a hőségnapok száma nem éri el a 15-öt, addig az LCZ 6-ban már meghaladja ezt az értéket (3.5. ábra). Egyre több területen 20 nap feletti lesz ez a szám, amely föleg az LCZ 6 belvároshoz közeli területein látványos. Az LCZ 5 és 8 területén a napok száma meghaladja a 25-öt, de az LCZ 8 egyes 
részein ez az érték a 30-at is túllépi. A kompakt zónák esetében a höségnapok 30 fölöttiek, de jelentős területi kiterjedésben jelennek meg a 35 feletti értékek is.

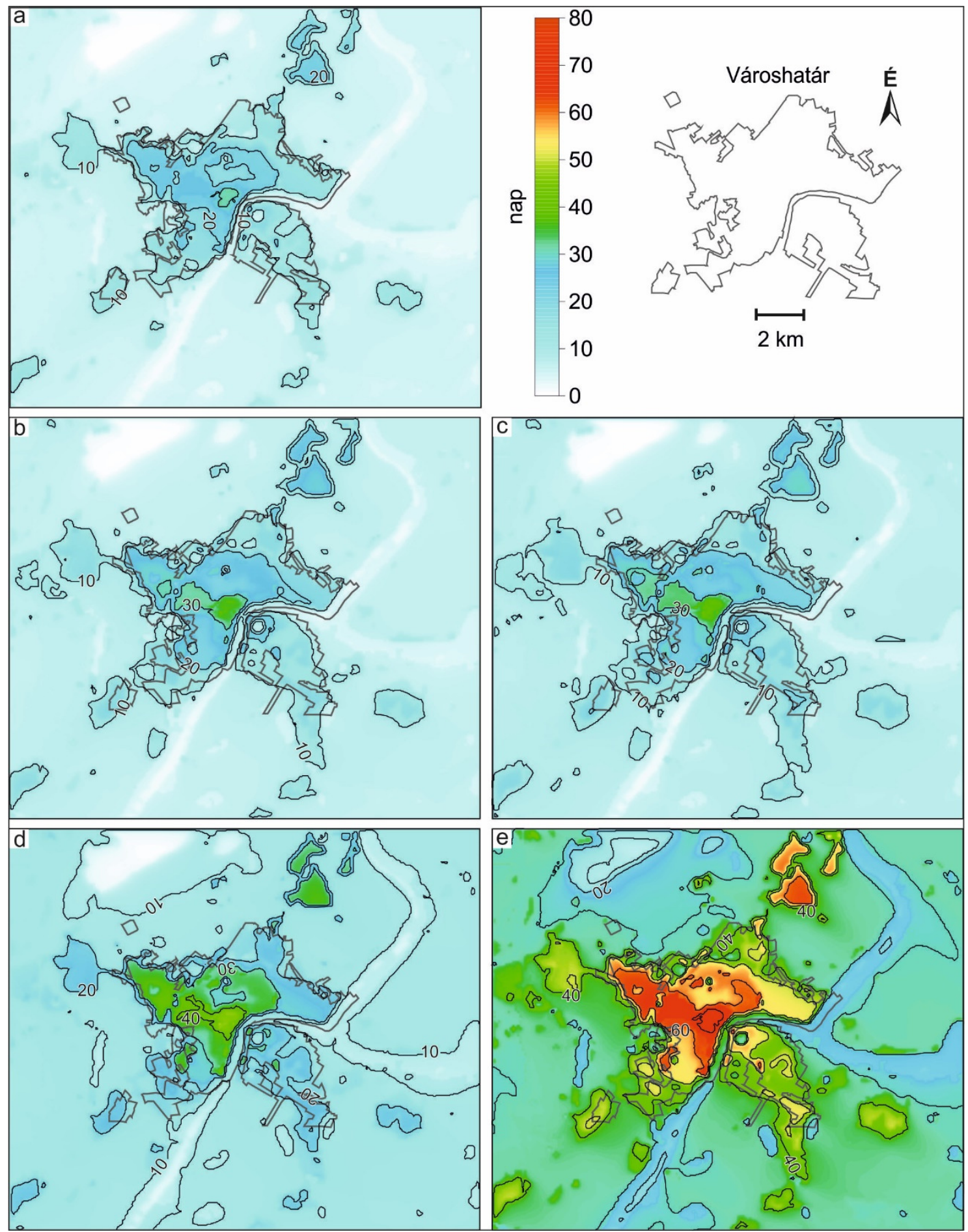

8.2. ábra: A höségnapok $\left(\mathrm{T}_{\max } \geq 30^{\circ} \mathrm{C}\right)$ számának modellezett területi eloszlása Szegeden és környezetében mérési és klímamodell adatok alapján (a: 1981-2010; b: 2021-2050, RCP4.5; c: 2021-2050, RCP8.5; d: 2071-2100, RCP4.5; e: 2071-2100, RCP8.5)

A század végére látványosabb változások következnek be, a hőségnapok esetében is igaz, hogy a két szcenárió között 20-30 nap közötti eltérés figyelhető meg $(8.2 \mathrm{~d}$., e. ábra). Az RCP4.5 szcenáriónál a város határával a 15 nap feletti értékek esnek egybe (8.2d. ábra). Az LCZ 9-ben a napok száma a város déli területein meghaladja 
a 20-at, a 25 feletti értékek csak az LCZ 6 területén jelennek meg (3.5. ábra). A belváros felé haladva tovább nő a napok száma, ami az LCZ 5 esetében már meghaladja a 30-at, a zóna belvároshoz közeli területein pedig a 35-öt. Az LCZ 8-nál már utóbbi a jellemző határvonal, de legbelső területein a 40 nap feletti értékek sem ritkák. A kompakt zónák területének nagy részén a hőségnapok száma már a 45-öt is meghaladja.

Az RCP8.5 szcenárió eredményeit tekintve a hőségnapok száma már a külterületen is 30-40 közötti (8.2e. ábra). A beépített terület és az LCZ 9 határát a 40 nap feletti értékek adják meg, míg az LCZ 6 nagy részén ez az érték már 50 fölötti, de ebben a zónában mindenhol meghaladja a 45 napot (3.5. ábra). Ha az LCZ 5 területét vizsgáljuk itt már jellemzően 50 nap feletti a hőségnapok száma és a belvárosi részeken a 60-at is meghaladja. Ez a 60 feletti érték a tipikus az LCZ 8 legnagyobb területén és a kompakt zónák peremén is, utóbbiak esetében a 70 nap feletti érték a jellemző, azaz a hőségnapok száma a 2 hónapot is meghaladja.

A hőségnapok zónaátlag szerinti változását a referencia időszak értékeihez viszonyítva, már a 2021-2050 időszakban akkora mértéket érnek el, amit a nyári napok esetében csak a század végén találhattunk (8.2. táblázat). A külterület értéke itt már 50 és $75 \%$, szcenáriótól függően, de már az LCZ 9 hőségnapjainak száma is a másfélszeresére nő. A zónák sorrendje az előző indexhez hasonlóan alakul és a közeljövőben 20, illetve 30\% körül rendre az RCP4.5 és RCP8.5 szerint. A 2071-2100 idöszakra bekövetkező változások már az optimistább szcenárió szerint is hatalmasnak bizonyulnak. A külterület értéke majdnem a háromszorosára nő és az LCZ 9 száma is megduplázódik, de - a legkisebb változást mutató - kompakt zónákban is meghaladja az 50\%-ot. Azonban az igazán látványos változások az RCP8.5 szerint következnek be, itt már a kompakt zónák értéke is majdnem a háromszorosára nő. A külterület esetében pedig egy rendkívül magas $650 \%$-os értéket láthatunk, amit nagyságrendben megközelít az LCZ 9 400\%-os értéke.

8.2. táblázat: $A$ höségnapok $\left(\mathrm{T}_{\max } \geq 30^{\circ} \mathrm{C}\right)$ lokális klímazónák szerinti átlagos száma az egyes időszakok és szcenáriók szerint, valamint relatív eltérésük az 1981-2010 időszaktól

\begin{tabular}{|l|c|c|c|c|c|c|c|}
\hline $\begin{array}{l}\text { Időszak } \\
\text { (szcenárió) }\end{array}$ & LCZ 2 & LCZ 3 & LCZ 5 & LCZ 6 & LCZ 8 & LCZ 9 & $\begin{array}{c}\text { LCZ A, } \\
\text { B és D }\end{array}$ \\
\hline $\mathbf{1 9 8 1 - 2 0 1 0}$ & 28 & 24 & 20 & 14 & 20 & 8 & 4 \\
\hline $\mathbf{2 0 2 1 - 2 0 5 0}$ & 33 & 29 & 24 & 17 & 24 & 11 & 6 \\
$\mathbf{( R C P 4 . 5 )}$ & $18 \%$ & $20 \%$ & $20 \%$ & $21 \%$ & $20 \%$ & $38 \%$ & $50 \%$ \\
\hline $\mathbf{2 0 2 1 - 2 0 5 0}$ & 35 & 31 & 26 & 19 & 26 & 12 & 7 \\
$\mathbf{( R C P 8 . 5 )}$ & $25 \%$ & $29 \%$ & $30 \%$ & $36 \%$ & $30 \%$ & $50 \%$ & $75 \%$ \\
\hline $\mathbf{2 0 7 1 - 2 1 0 0}$ & 42 & 38 & 32 & 24 & 32 & 17 & 10 \\
(RCP4.5) & $50 \%$ & $58 \%$ & $60 \%$ & $71 \%$ & $60 \%$ & $113 \%$ & $150 \%$ \\
\hline $\mathbf{2 0 7 1 - 2 1 0 0}$ & 69 & 64 & 58 & 49 & 57 & 40 & 30 \\
(RCP8.5) & $146 \%$ & $167 \%$ & $190 \%$ & $250 \%$ & $185 \%$ & $400 \%$ & $650 \%$ \\
\hline
\end{tabular}

\subsection{Sörkerti napok és nyári esték}

Az ebben a fejezetben bemutatott klímaindexek egy-egy időpont hőmérsékleti értékéhez köthetők. A sörkerti napok esetében a nyári helyi időben megadott 20 órai hőmérsékletnek kell elérnie vagy meghaladnia a $20{ }^{\circ} \mathrm{C}$-ot. 


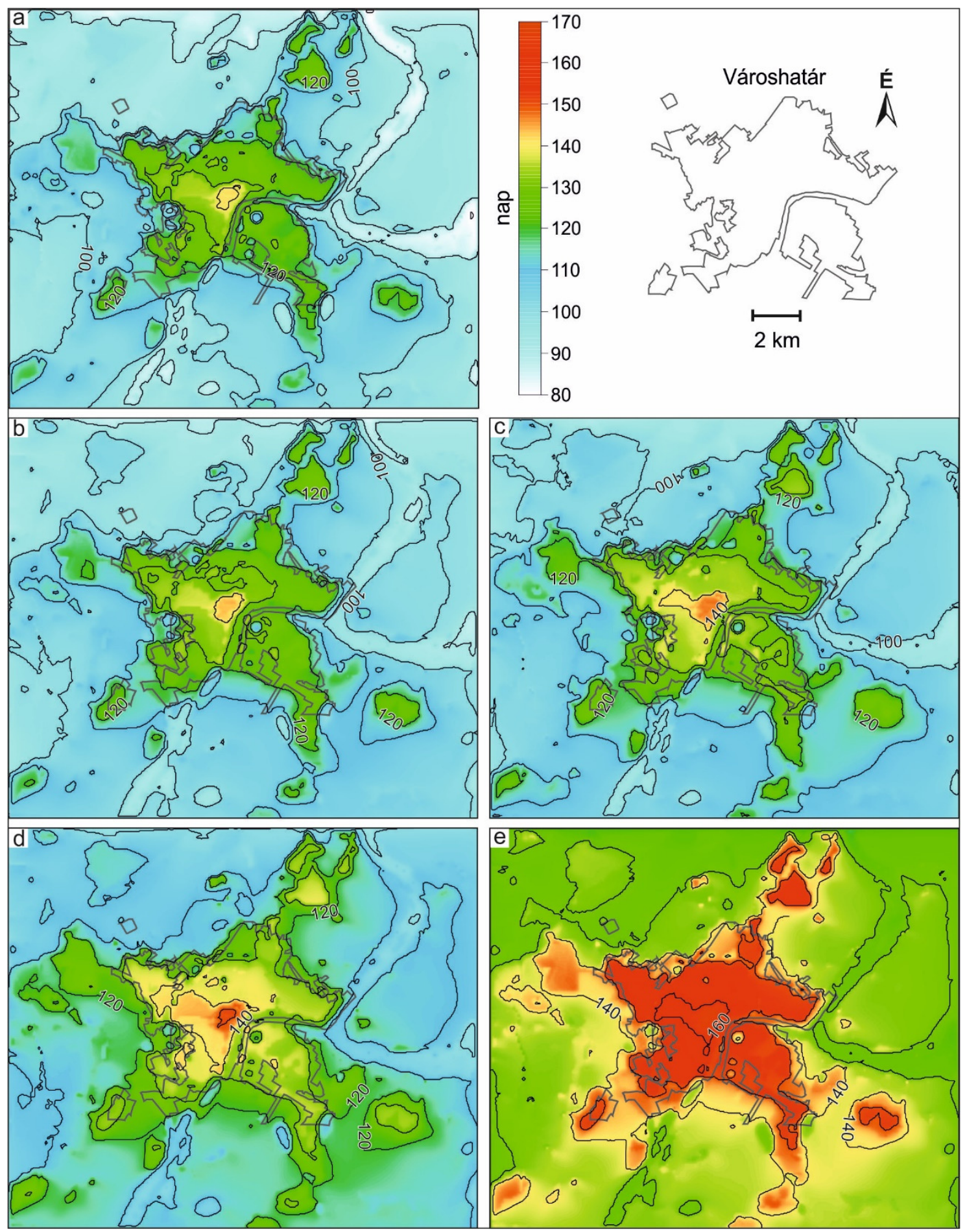

8.3. ábra: A sörkerti napok $\left(\mathrm{T}_{20 \mathrm{~h}^{*}} \geq 20^{\circ} \mathrm{C}\right)$ számának modellezett területi eloszlása Szegeden és környezetében mérési és klímamodell adatok alapján (a: 1981-2010; b: 2021-2050, RCP4.5; c: 2021-2050, RCP8.5; d: 2071-2100, RCP4.5; e: 2071-2100, RCP8.5)

*Közép-európai nyári idő

A sörkerti napok száma az 1981-2010 időszakban a vizsgált területen 78-142 között változik (8.3a. ábra). A külterület nagy részén a napok száma 90-100 között alakul, a 90 alattiak a vízfelszínek, a 100 felettiek a beépített területhez közeledve jellemzők. A városhatár mentén a 110 nap feletti értékek jelennek meg, de a város területén már a 120 napot is meghaladják. Az LCZ 6 és 9 valamennyi, illetve az LCZ 5 és 8 legtöbb területén 
a 110-130 nap közötti értékek a tipikusak (3.5. ábra). Utóbbi két zóna esetében a belvároshoz közel már a 130 nap feletti a jellemző, a kompakt zónákban pedig ez a szám már a 140 -et is meghaladja.

A 2021-2050 időszakban már a külterület nagy részén 100 nap feletti értékeket láthatunk ( $8.3 \mathrm{~b}$. ábra), amelyeknek területe az RCP 8.5 szcenáriónál még inkább szembetűnő (8.3c. ábra). Valamennyi, kiterjedésben történő változás a pesszimistább szcenáriónál jelenik meg leginkább, de az RCP4.5 esetében sem elhanyagolható. Látványos a 110 nap feletti értékeket mutató izovonal kiterjedése is, ami ismét a külterületen történő változásokat tükrözi. A város határa mentén továbbra is a 120 nap feletti értékek jellemzők, ennél az értéknél a városhatártól északnyugatra van jelentős különbség a két szcenárió között. Míg az RCP4.5 szerint az LCZ 6 és 9 esetében 120 és 130 közötti a napok száma, addig az RCP8.5 alapján az LCZ 6 legtöbb területén ez a szám már meghaladja a 130-at (3.5. ábra). Ha az LCZ 5-öt és 8-at tekintjük, mindkét szcenárió a 130 és 140 nap közötti értékeket valószínűsíti. Ebben az időszakban a 140 feletti értékek területi kiterjedése még nem jelentős; mindkét forgatókönyv szerint inkább a kompakt zónákat jellemzik, csak az RCP8.5-nél nyúlik kissé át az LCZ 8-ba.

A 2071-2100 időszakban a két szcenárió nagyon hasonló területi eloszlást mutat, csupán az értékek nagysága különbözik 20 nappal (8.3d., e. ábra). A külterületen a sörkerti napok száma az RCP4.5 szerint 100-120 között alakul. Az LCZ 6 és 9 értékei 120 és 140 nap között változnak a belvárostól való távolság függvényében (3.5. ábra). Az LCZ 5 és 8 legtöbb külső területén a 130-140, de a belvárosban már a 140-150 nap a jellemző és a kompakt zónák területén megjelennek a 150 felettiek is. Az RCP8.5-nél az előbbi leírt tendenciák ugyanígy megfigyelhetők az említett magasabb értékkel, csak a belvárosban nem éri el a 170-et a napok száma (8.3e. ábra).

8.3. táblázat: A sörkerti napok $\left(\mathrm{T}_{20 \mathrm{~h}^{*}} \geq 20^{\circ} \mathrm{C}\right)$ lokális klímazónák szerinti átlagos száma az egyes időszakok és szcenáriók szerint, valamint relatív eltérésük az 1981-2010 időszaktól

\begin{tabular}{|l|c|c|c|c|c|c|c|}
\hline $\begin{array}{l}\text { Időszak } \\
\text { (szcenárió) }\end{array}$ & LCZ 2 & LCZ 3 & LCZ 5 & LCZ 6 & LCZ 8 & LCZ 9 & $\begin{array}{c}\text { LCZ A, } \\
\text { B és D }\end{array}$ \\
\hline $\mathbf{1 9 8 1 - 2 0 1 0}$ & 139 & 137 & 128 & 120 & 125 & 112 & 95 \\
\hline $\mathbf{2 0 2 1 - 2 0 5 0}$ & 141 & 139 & 130 & 123 & 126 & 115 & 100 \\
(RCP4.5) & $1 \%$ & $2 \%$ & $2 \%$ & $3 \%$ & $1 \%$ & $3 \%$ & $5 \%$ \\
\hline $\mathbf{2 0 2 1 - 2 0 5 0}$ & 144 & 143 & 134 & 126 & 130 & 119 & 104 \\
$\mathbf{( R C P 8 . 5 )}$ & $4 \%$ & $4 \%$ & $5 \%$ & $5 \%$ & $4 \%$ & $6 \%$ & $10 \%$ \\
\hline $\mathbf{2 0 7 1 - 2 1 0 0}$ & 148 & 146 & 138 & 132 & 135 & 125 & 111 \\
(RCP4.5) & $7 \%$ & $7 \%$ & $8 \%$ & $10 \%$ & $8 \%$ & $12 \%$ & $17 \%$ \\
\hline $\mathbf{2 0 7 1 - 2 1 0 0}$ & 165 & 164 & 156 & 150 & 153 & 144 & 132 \\
(RCP8.5) & $19 \%$ & $20 \%$ & $22 \%$ & $25 \%$ & $22 \%$ & $29 \%$ & $39 \%$ \\
\hline
\end{tabular}

*Közép-európai nyári idő

A sörkerti napok zónák szerinti átlagában nem következik be akkora változás, mint az előző alfejezetben ismertetett indexeknél (8.3. táblázat). A 2021-2050 időszakban az RCP4.5 szerint csak a külterület értéke éri el az 5\%-ot és a változás az RCP8.5 szerint is csupán $10 \%$. A beépített zónák értékei ennél is kisebbek és az RCP 8.5 alapján is csak 5\% körül alakulnak. A 2071-2100 időszakban az RCP4.5 szerint a külterületen, valamint az LCZ 9 és 6-ban éri el a változás a 10\%-ot. A többi zóna esetében ez az érték csak 7$8 \%$ körüli. A pesszimistább szcenáriót tekintve következnek be nagyobb változások, de ennek mértéke a külterület esetén se éri el a 40\%-ot és a belterületen csak az LCZ 9-nél közelíti meg a 30\%-ot. 


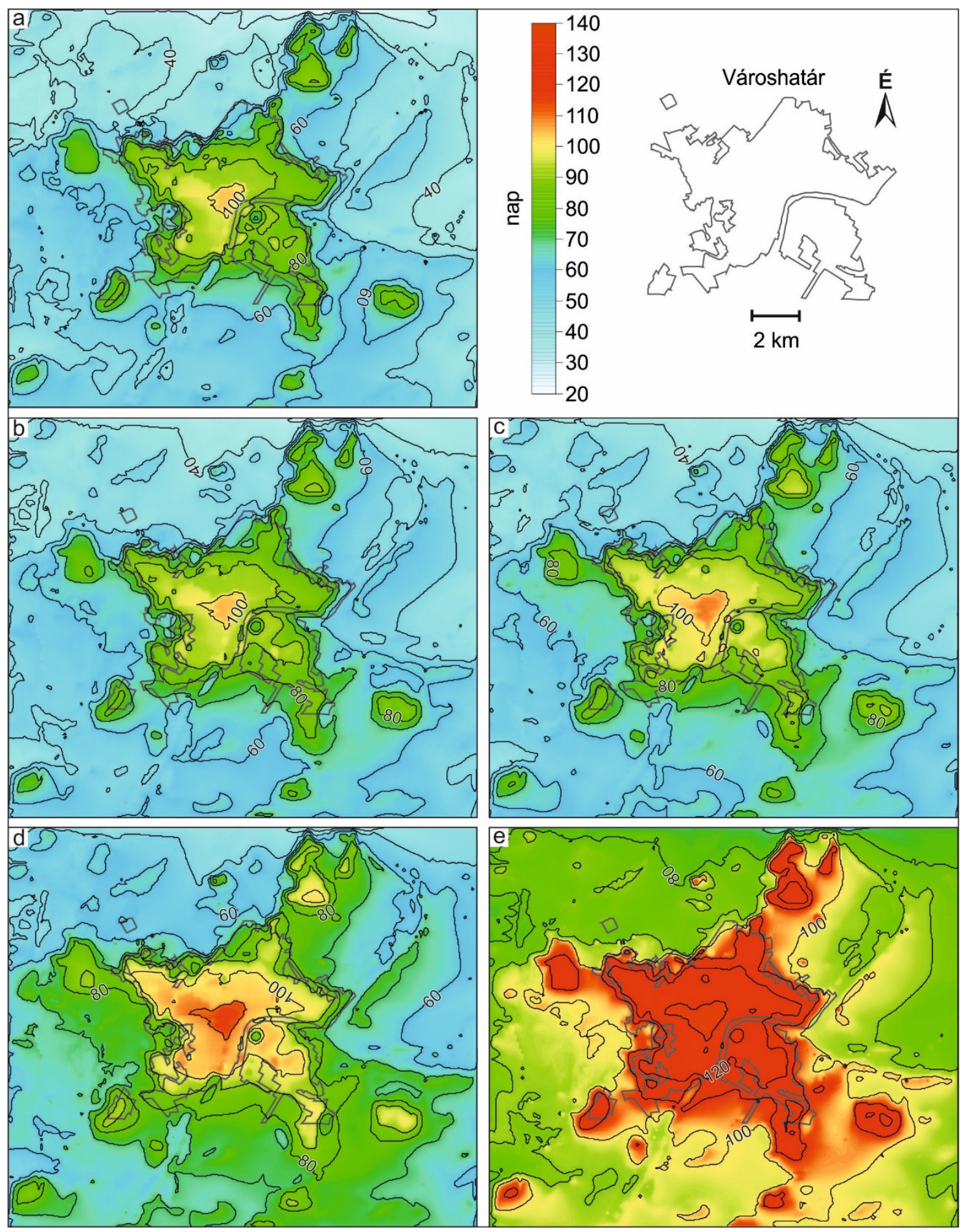

8.4. ábra: A nyári esték $\left(\mathrm{T}_{22 \mathrm{~h}^{*}} \geq 20^{\circ} \mathrm{C}\right)$ számának modellezett területi eloszlása Szegeden és környezetében mérési és klímamodell adatok alapján (a: 1981-2010; b: 2021-2050, RCP4.5; c: 2021-2050, RCP8.5; d: 2071-2100, RCP4.5; e: 2071-2100, RCP8.5)

*Közép-európai nyári idő

A nyári esteként elnevezett index esetében már a nyári, helyi idő szerinti 22 óra hömérsékletének kell meghaladnia a $20^{\circ} \mathrm{C}$-ot. Definíciójának köszönhetően látható, hogy értéke kisebb, mint a sörkerti napoké (8.4. ábra). Az 1981-2010 referencia időszakban a nyári esték száma 22-104 között alakul (8.4a. ábra). A külterületen is alakulnak ki jelentősebb különbségek, hiszen egészen északon ezen esték száma 40 alatti, majd délebbre haladva eléri az 50-et, és a várost megközelítve a 60-at (3.5. 
ábra). A városhatár mentén a 70 feletti értékek a jellemzők, amely szám az LCZ 9 tipikus értékének is tekinthető. A jellemző északnyugati szél hatásának következtében az ebben az irányban fekvő beépített területtel az LCZ 6 értéke nem haladja meg a 80 -at, ellentétben Szegeddel és a többi környező településsel. A város bentebb fekvő területein az LCZ 6 értéke a 90-et is meghaladja. Ugyanez a nagyság jellemezi az LCZ 5 és 8 területeit is, a 100 fölötti értékek csak a kompakt zónában fordulnak elő.

A 2021-2050 időszakra az előzőekben említett határvonalak terjedése figyelhető meg, amely ismét az RCP8.5 szcenárió esetében látványos (8.4b., c. ábra). A külterületet tekintve a 40 alatti értékek egyre inkább északabbra szorulnak és legnagyobb részén 50-70 közötti lesz a nyári esték száma. A város területén sem történnek kiemelkedő változások, megjegyezhető, hogy az LCZ 9 több, illetve LCZ 6 valamennyi területén a 80 feletti értékek lesznek a jellemzők (3.5. ábra). A 90 feletti értékek területi kiterjedése is nő, főként a Tisza bal partján, de az RCP8.5 szerint a város keleti részén is, azaz egyre inkább ez az érték jellemzi az LCZ 6-ot. Az LCZ 5-ben és 8-ban maradnak a 90-100 közötti értékek, de ha a pesszimistább jövőképet tekintjük, akkor az LCZ 8-ban már megjelennek a kompakt zónákra jellemző 100 feletti értékek is.

A 2071-2100 időszakra jelentősebb változáson megy keresztül a nyári esték száma (8.4d., e. ábra). A szcenáriók között a külterületen jellemzően 30, míg a beépített területen 20 nap eltérés vehető észre. Így míg az RCP4.5 szerint a külterületen az értékek 50-80 között alakulnak, addig ez a szám RCP8.5 esetében már 80-100 közé esik. Az RCP4.5 alapján az LCZ 6 és 9 tipikus értéke pár kisebb területtől eltekintve mindenhol 90, némely területen pedig 100 feletti, ami az LCZ 5-re és 8-ra jellemző is egyben (3.5. ábra). A kompakt zónákban a nyári esték száma ebben az időszakban már 110 feletti, amelynek határvonala kinyúlik az LCZ 8 felé is. Az RCP8.5 szerint már az LCZ 6 és 9-ben is ez a 110 feletti érték a legtipikusabb, de egyes területeken a 120-as határ is megjelenik, ami az említett zónák mellett az LCZ 5-öt és 8-at is jellemzi (8.4e. ábra). E szcenárió szerint a kompakt zónákban már nem kevesebb, mint 130 feletti lesz a nyári esték száma.

8.4. táblázat: A nyári esték $\left(\mathrm{T}_{22 \mathrm{~h}^{*}} \geq 20^{\circ} \mathrm{C}\right)$ lokális klímazónák szerinti átlagos száma az egyes időszakok és szcenáriók szerint, valamint relatív eltérésük az 1981-2010 időszaktól

\begin{tabular}{|l|c|c|c|c|c|c|c|}
\hline $\begin{array}{l}\text { Időszak } \\
\text { (szcenárió) }\end{array}$ & LCZ 2 & LCZ 3 & LCZ 5 & LCZ 6 & LCZ 8 & LCZ 9 & $\begin{array}{c}\text { LCZ A, } \\
\text { B és D }\end{array}$ \\
\hline $\mathbf{1 9 8 1 - 2 0 1 0}$ & 102 & 100 & 90 & 78 & 82 & 65 & 50 \\
\hline $\mathbf{2 0 2 1 - 2 0 5 0}$ & 103 & 101 & 91 & 80 & 84 & 68 & 55 \\
$\mathbf{( R C P 4 . 5 )}$ & $1 \%$ & $1 \%$ & $1 \%$ & $3 \%$ & $2 \%$ & $5 \%$ & $10 \%$ \\
\hline $\mathbf{2 0 2 1 - 2 0 5 0}$ & 107 & 105 & 94 & 83 & 87 & 71 & 57 \\
(RCP8.5) & $5 \%$ & $5 \%$ & $4 \%$ & $6 \%$ & $6 \%$ & $9 \%$ & $14 \%$ \\
\hline $\mathbf{2 0 7 1 - 2 1 0 0}$ & 114 & 112 & 102 & 91 & 95 & 80 & 66 \\
(RCP4.5) & $12 \%$ & $12 \%$ & $13 \%$ & $17 \%$ & $16 \%$ & $23 \%$ & $32 \%$ \\
\hline $\mathbf{2 0 7 1 - 2 1 0 0}$ & 134 & 132 & 123 & 114 & 118 & 105 & 94 \\
(RCP8.5) & $31 \%$ & $32 \%$ & $37 \%$ & $46 \%$ & $44 \%$ & $62 \%$ & $88 \%$ \\
\hline
\end{tabular}

*Közép-európai nyári idő

A nyári esték zónák szerinti átlagszáma nagyobb mértékben növekszik a 21. század során, mint a sörkerti napok értéke, de ebben az esetben sem beszélhetünk olyan nagy változásokról, mint a nappali indexek esetében (8.4. táblázat). A külterületen a 20212050 időszakban a változás mértéke meghaladja a 10\%-ot az RCP8.5 szerint, de a beépített terület zónáiban továbbra is $5 \%$ körüli értékek a tipikusak az LCZ 9 kivételével, ahol ez megközelíti a 10\%-ot. A századvégén az RCP4.5 alapján a külterület változása meghaladja a 30\%-ot, a nyitottabb beépítettséggel jellemzett zónákban ez 
az érték $20 \%$ körül alakul. A változás mértéke a kompakt zónákban és az LCZ 5-ben a legkisebb (12-13\%). Jóllehet az RCP8.5 szerint jelentős változások jelennek meg, ez nem akkora mértékü, mint a korábbi indexeknél. Leginkább a külterület és az LCZ 9 értéke magasabb, rendre $88 \%$ és $62 \%$, a kompakt zónák értéke ellenben alig haladja meg a $30 \%$-ot.

\subsection{Meleg és trópusi éjszakák}

A meleg és trópusi éjszakák definíciója a minimum-hőmérsékletet veszi alapul, míg előbbinél a $17{ }^{\circ} \mathrm{C}$-ot, addig utóbbinál a $20{ }^{\circ} \mathrm{C}$-ot kell meghaladnia. Ebből következően a meleg éjszakák száma a nagyobb, szám szerint az 1981-2010 időszakot tekintve 4 és 64 nap között alakul (8.5a. ábra). A külterületen, északkeleti és északnyugati irányokban 10-20 közötti a meleg éjszakák száma, de a vízfelszínek felett a 40 fölötti értékek is megjelennek. A városhatártól délre, a külterület nagy részén 20 felettiek az értékek, de a Tisza vonala mentén és a környező települések környezetében a 30-at is meghaladják. Az LCZ 6-ban és 9-ben a város közelségétől függően 20, illetve 30 fölötti a szám, de elöbbi belvároshoz közeli területein ez a 40-et is meghaladja (3.5. ábra). Az LCZ 5 és 8 kintebb fekvő részein szintén az efölötti érték a jellemző, de a belváros mentén már 50 felettiek. A maximális, 60 feletti értékek csak az LCZ 2 területén jelennek meg, az LCZ 3 területén nem érik el ezt az értéket.

A 2021-2050 időszakot tekintve az RCP4.5-nél a változások nem jelentősek, valamennyi izovonal területi kiterjedése megnő, ami leginkább a 30 feletti értékeknél figyelhető meg a várostól délkeletre (8.5b. ábra). Hasonló változások mutatkoznak meg az RCP8.5-nél is, itt már nagyobb területen, de szintén elhanyagolható mértékben (8.5c. ábra). Az előbbi szcenáriónál kiemelt változás itt sokkal nagyobb területet érint, emellett a városhatáron belül is észrevehetőbb átalakulások történnek. Mind az 50-es, mind pediga 60-as érték határát jelző izovonal kiterjedése növekszik, ami előbbinél a látványosabb, hiszen az LCZ 5 és 8 területére egyre inkább benyúlik a Tisza bal partján is (3.5. ábra).

Az igazán számottevő változások a század végén következnek be, ami mindkét szcenárió esetében jelentős mértékü az előbbi vizsgált időszakokhoz képest ( $8.5 \mathrm{~d}$., e. ábra). A szcenáriók közötti különbségek az előző indexekhez hasonlóan alakulnak, azaz az index értéke megközelítőleg 30-cal nagyobb az RCP8.5 szcenárió szerint. Az RCP4.5 alapján, a külterületen a meleg éjszakák száma 30-40 közötti, azaz megközelítőleg 10-zel növekszik az előző időszakokhoz képest, ami a beépített terület esetében is megfigyelhető ( $8.5 \mathrm{~d}$. ábra). Ennek köszönhetően az LCZ 6 és 9 esetében az érték 40-60 között változik és a legtöbb területen 50 fölötti (3.5. ábra). Az LCZ 5 és 8 területén a belvárosban már 60 feletti a meleg éjszakák száma, de a zónák nagyrészén is meghaladják az 50-et. Az RCP8.5 szcenáriót tekintve a külterület legnagyobb részén 50-70 között alakul az éjszakák száma, amelyek a várostól délkeletre a legmagasabbak, itt a városhatárhoz közel a 70-et is meghaladják. Az LCZ 9 értékei a város területén 60-70, míg az LCZ 6-ra 70-90 közöttiek, a 80 fölötti értékek a belvároshoz közel jelennek meg. Az LCZ 5 és 8 jellemző értékei 80 és 90 fölött alakulnak, a kompakt zónák értékei is 90 fölöttiek.

A zónaátlagokat tekintve a meleg éjszakák száma a 21. század során csak a század végére mutat látványos változást (8.5. táblázat). A 2021-2050 időszakban az RCP4.5 szerinti változások elenyészők és a 8.5 alapján is csak az LCZ 9-ben és külterületen érik el a 10\%-ot, a többi zóna esetében 5-8\% között alakul. A 2071-2100 időszakban az RCP4.5 szerint a külterületen és az LCZ 9-ben a változás már $40 \%$ körüli, de a 
többi zónában is 20-30\% körül változik. Az igazán jelentős változás az RCP8.5 szerint történik ismét, ami a zónák többségében az értékek megduplázódását eredményezi, csak a kompakt zónákban és az LCZ 5-ben kisebb a változás, de ez sem mondható alacsonynak.

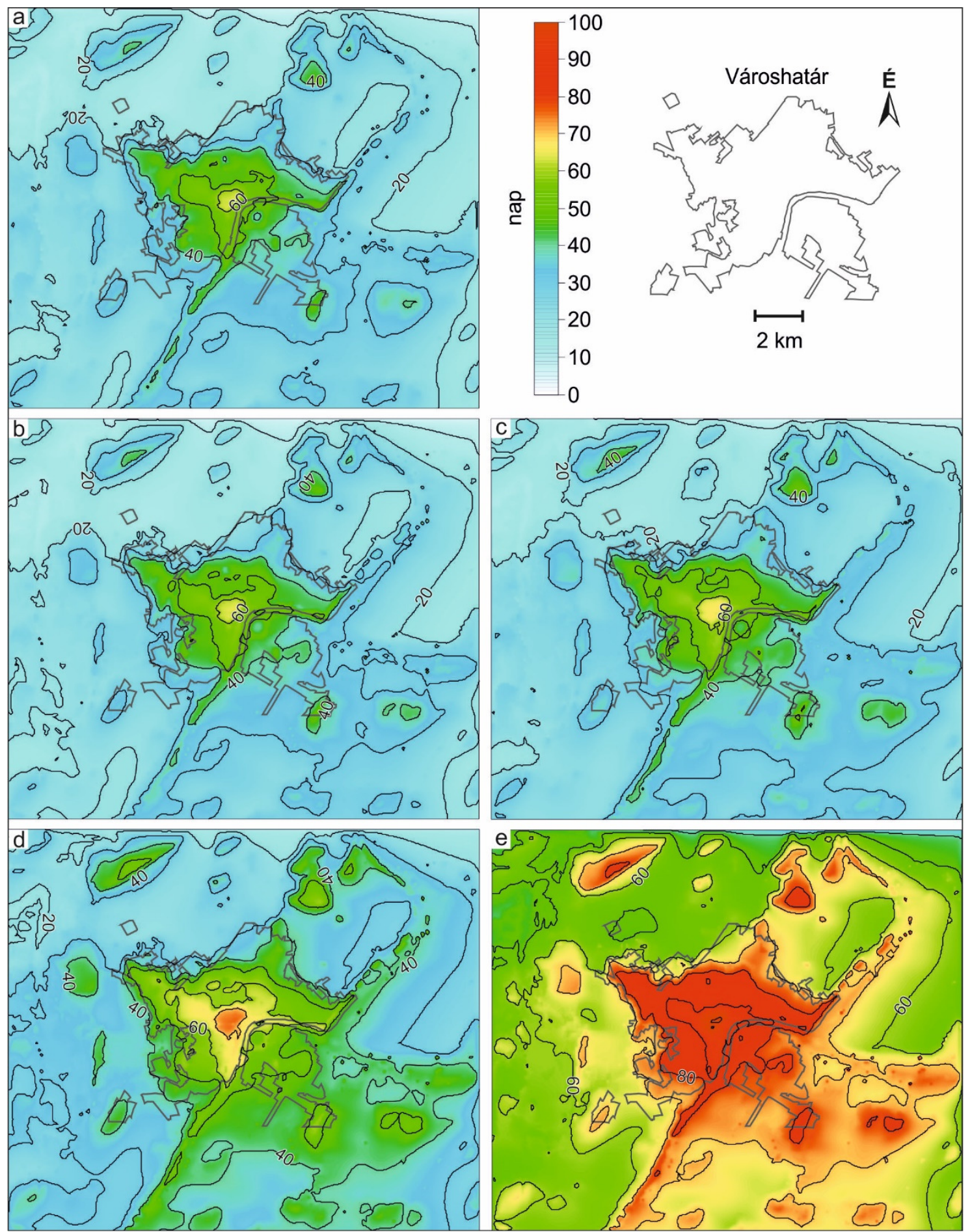

8.5. ábra: A meleg éjszakák $\left(\mathrm{T}_{\min } \geq 17^{\circ} \mathrm{C}\right)$ számának modellezett területi eloszlása Szegeden és környezetében mérési és klímamodell adatok alapján (a: 1981-2010; b: 2021-2050, RCP4.5; c: 2021-2050, RCP8.5; d: 2071-2100, RCP4.5; e: 2071-2100, RCP8.5) (Skarbit, Gál, 2016) 
8.5. táblázat: A meleg éjszakák $\left(\mathrm{T}_{\min } \geq 17^{\circ} \mathrm{C}\right)$ lokális klímazónák szerinti átlagos száma az egyes időszakok és szcenáriók szerint, valamint relatív eltérésük az 1981-2010 időszaktól (Skarbit, Gál, 2016)

\begin{tabular}{|l|c|c|c|c|c|c|c|}
\hline $\begin{array}{l}\text { Időszak } \\
\text { (szcenárió) }\end{array}$ & LCZ 2 & LCZ 3 & LCZ 5 & LCZ 6 & LCZ 8 & LCZ 9 & $\begin{array}{c}\text { LCZ A, } \\
\text { B és D }\end{array}$ \\
\hline $\mathbf{1 9 8 1 - 2 0 1 0}$ & 60 & 55 & 47 & 35 & 38 & 28 & 25 \\
\hline $\mathbf{2 0 2 1 - 2 0 5 0}$ & 61 & 56 & 48 & 35 & 39 & 28 & 25 \\
$(\mathbf{R C P 4 . 5 )}$ & $2 \%$ & $2 \%$ & $2 \%$ & $0 \%$ & $3 \%$ & $0 \%$ & $0 \%$ \\
\hline $\mathbf{2 0 2 1 - 2 0 5 0}$ & 63 & 59 & 50 & 37 & 41 & 31 & 28 \\
$\mathbf{( R C P 8 . 5 )}$ & $5 \%$ & $7 \%$ & $6 \%$ & $6 \%$ & $8 \%$ & $11 \%$ & $12 \%$ \\
\hline $\mathbf{2 0 7 1 - 2 1 0 0}$ & 72 & 67 & 59 & 46 & 50 & 39 & 36 \\
(RCP4.5) & $20 \%$ & $22 \%$ & $26 \%$ & $31 \%$ & $32 \%$ & $39 \%$ & $44 \%$ \\
\hline $\mathbf{2 0 7 1 - 2 1 0 0}$ & 97 & 93 & 86 & 74 & 77 & 67 & 65 \\
(RCP8.5) & $62 \%$ & $69 \%$ & $83 \%$ & $111 \%$ & $103 \%$ & $139 \%$ & $160 \%$ \\
\hline
\end{tabular}

A trópusi éjszakák száma - szigorúbb definíciójának köszönhetően - az indexek közül a legkisebb, az 1981-2010 időszakban csak 0-18 közötti a vizsgált területen (8.6a. ábra). Értéke a város határán kívül csak néhány helyen haladja meg az 5-öt, ott ahol, beépített terület található (pl. északkeletre). A városon belül az LCZ 9-ben és az LCZ 6 több területén a napok száma 5 alatti marad (3.5. ábra). Szeged legnagyobb részén azonban 5-10 közötti trópusi éjszaka fordul elö, és ez a zónák többségére jellemző. Egyedül az LCZ 5 és 8, illetve a kompakt zónák területén fordul elő rendre 10 és 15 feletti érték.

A 2021-2050 időszakban az RCP4.5 szerint alig változik a trópusi éjszakák száma, hiszen csak a 10 feletti értékeket jelzö izovonal kismértékü megnövekedése figyelhető meg az LCZ 5-ben és 8-ban (8.6b. ábra). Annak ellenére, hogy az RCP8.5 esetében ezek a változások már látványosabbak, a változások mértéke itt sem számottevő (8.6c. ábra). Jelen forgatókönyv szerint is a legnagyobb változás a 10 feletti értékek egyre nagyobb területen történő megjelenése, ami a város határán kívül is felfedezhető, de a belváros területén a legszembetünőbb. Emellett nem elhanyagolható változás, hogy az LCZ 2 területén a trópusi éjszakák száma meghaladhatja a 20-at.

Az előbbi indexhez hasonlóan a számottevő változások jelen esetben is a 20712100 időszakban jelennek meg (8.6d., e. ábra), és az RCP8.5 szerint sokkal nagyobb mértéküek (RCP4.5-höz képest +20$)$. Az RCP4.5 szerint már a külterületen is egyre nagyobb területen jelennek meg az 5, illetve a 10 feletti értékek, de a város délkeleti végén még 15 felettiek is megjelenhetnek (8.6d. ábra). A város területén látványosan továbbterjed a 10 és 15 feletti értéket jelző izovonal északnyugati irányba, valamint a Tisza mentén. Ennek eredményeképpen a belvároshoz közel az LCZ 6 területein már 10, míg az LCZ 5-ben és 8-ban 15 feletti értékek jellemzők (3.5. ábra). Továbbá, ebben az időszakban a kompakt zónák értékei az RCP4.5 szerint már 25 felettiek. Az RCP8.5 szerint a külterület nagy részén (az északabbra fekvő területek kivételével) már 15, délkeleten 20 feletti a trópusi éjszakák száma (8.6e. ábra). A városhatáron belül az LCZ 9 értékei 25, az LCZ 6-é 30, illetve - a belvároshoz közeledve - 35 felettiek. Az LCZ 5-ben és 8-ban jellemzően 30 és 35 feletti az éjszakák száma, de a 40 feletti értékek is megjelennek, míg a kompakt zónák értékei ekkor már 45-öt is meghaladják. Ezek alapján a beépített zónák többségében a trópusi éjszakák száma már az 1 hónapot is meghaladhatja. 


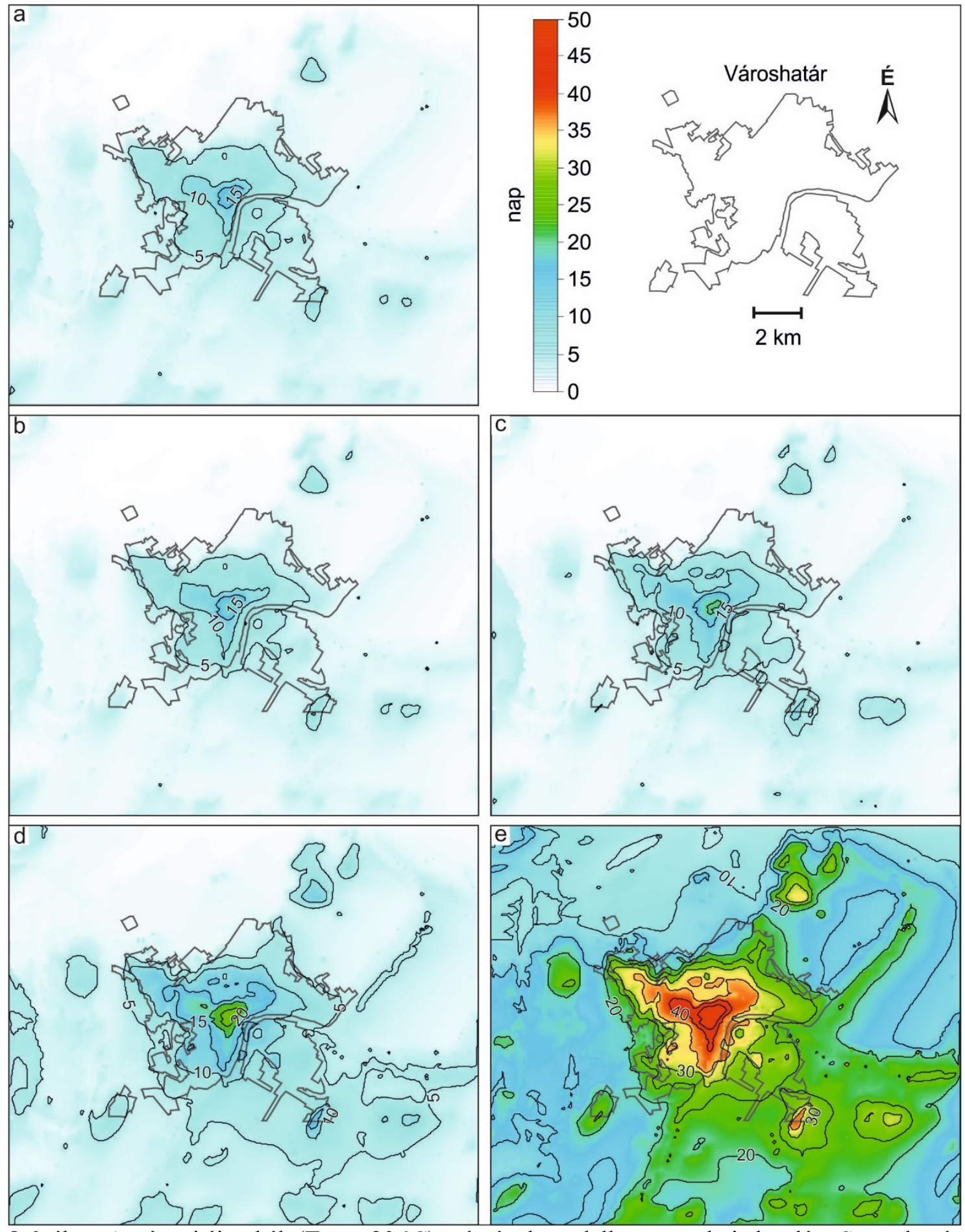

8.6. ábra: A trópusi éjszakák $\left(\mathrm{T}_{\min } \geq 20^{\circ} \mathrm{C}\right)$ számának modellezett területi eloszlása Szegeden és környezetében mérési és klímamodell adatok alapján (a: 1981-2010; b: 2021-2050, RCP4.5; c: 2021-2050, RCP8.5; d: 2071-2100, RCP4.5; e: 2071-2100, RCP8.5) (Skarbit, Gál, 2016)

A zónátlagokat tekintve a trópusi éjszakák számánál a 2021-2050 időszakban egyedülálló módon a beépített zónákban tapasztalható nagyobb változás (8.6. táblázat). $\mathrm{Az}$ RCP4.5 szerint LCZ 6, 8 és 9, valamint a beépített területeken nem tapasztalható változás és ez RCP8.5 alapján is így marad az LCZ 9-ben, valamint a külterületen. A trópusi éjszakák esetében a 2071-2100 időszakban már az RCP4.5 szerinti változások is nagymértéküek, hiszen az értékek a kétszeresükre nőnek az LCZ 5, 6 és 8 esetében, valamint a külterületen. Jelen esetben kivételesen az LCZ 9 értéke nem magas, hanem csak az 
LCZ 3-éval megegyező nagyságú. A klímaindexek közül a trópusi éjszakákra jellemző leginkább az értékek megnövekedése, amennyiben a századvégi pesszimistább szcenáriót tekintjük. Ez a külterület esetében $800 \%$-os változást jelent, de a beépített területen is jelentős, hiszen az LCZ 9 esetében eléri a $600 \%$-ot. A legkisebb változás ismét a kompakt zónákat érinti, de ez a növekedés is az értékek megtriplázódását jelenti.

8.6. táblázat: A trópusi éjszakák $\left(\mathrm{T}_{\min } \geq 20^{\circ} \mathrm{C}\right)$ lokális klímazónák szerinti átlagos száma az egyes időszakok és szcenáriók szerint, valamint relatív eltérésük az 1981-2010 időszaktól (Skarbit, Gál, 2016)

\begin{tabular}{|l|c|c|c|c|c|c|c|}
\hline $\begin{array}{l}\text { Időszak } \\
\text { (szcenárió) }\end{array}$ & LCZ 2 & LCZ 3 & LCZ 5 & LCZ 6 & LCZ 8 & LCZ 9 & $\begin{array}{c}\text { LCZ A, } \\
\text { B és D }\end{array}$ \\
\hline $\mathbf{1 9 8 1 - 2 0 1 0}$ & 15 & 12 & 7 & 4 & 5 & 3 & 2 \\
\hline $\mathbf{2 0 2 1 - 2 0 5 0}$ & 16 & 13 & 8 & 4 & 5 & 3 & 2 \\
$\mathbf{( R C P 4 . 5 )}$ & $7 \%$ & $8 \%$ & $14 \%$ & $0 \%$ & $0 \%$ & $0 \%$ & $0 \%$ \\
\hline $\mathbf{2 0 2 1 - 2 0 5 0}$ & 18 & 14 & 9 & 5 & 6 & 3 & 2 \\
$\mathbf{( R C P 8 . 5 )}$ & $20 \%$ & $17 \%$ & $29 \%$ & $25 \%$ & $20 \%$ & $0 \%$ & $0 \%$ \\
\hline $\mathbf{2 0 7 1 - 2 1 0 0}$ & 23 & 20 & 14 & 8 & 10 & 5 & 4 \\
(RCP4.5) & $53 \%$ & $67 \%$ & $100 \%$ & $100 \%$ & $100 \%$ & $67 \%$ & $100 \%$ \\
\hline $\mathbf{2 0 7 1 - 2 1 0 0}$ & 45 & 41 & 34 & 25 & 28 & 21 & 18 \\
(RCP8.5) & $200 \%$ & $242 \%$ & $386 \%$ & $525 \%$ & $460 \%$ & $600 \%$ & $800 \%$ \\
\hline
\end{tabular}

\subsection{A klímaindex előrejelzés validációja}

Annak érdekében, hogy a külterület és belterület értékeinek összehasonlítása is lehetséges legyen, az 1999-2010 időszak klímaindexeinek számát is modelleztem, hiszen a referencia időszak ezen részében már belterületi mérések is rendelkezésre álltak Szegeden. A 8.7. táblázat alapján látható, hogy a modell a belterületen teljesít a legjobban, ezen belül is a nyári és hőságnapok, valamint a meleg és trópusi éjszakák esetében (lásd megvastagított keret). A nappali, maximum-hőmérséklethez köthető indexek esetében a külterületen a modell eléggé alulbecsül, főként a szigorúbb kritériummal rendelkező hőségnapok esetében. Ugyanakkor a belterületen a relatív eltérés $10 \%$ alatt marad és pozitív irányú. Jelen esetben a modell fő problémájának az tekinthető, hogy nappal is jelentősen melegebbnek tartja a városi területet a külterületnél, ami ismereteink mellett a mérések alapján sem helytálló (4.1. fejezet). Azonban mindenképpen pozitívként értékelhetö, hogy a vizsgálat szempontjából elsődleges környezetben, azaz a városban nagyságrendileg helyes eredményeket sikerült elérni.

8.7. táblázat: Az egyes klímaindexek mért és modellezett száma Szeged külterületi és belterületi állomásain az 1999-2010 időszakban, valamint a modellezett értékek relatív eltérése a mérésektől

\begin{tabular}{|c|c|c|c|c|c|c|}
\hline \multirow{3}{*}{$\begin{array}{l}\text { Klímaindex } \\
\text { (definició) }\end{array}$} & \multicolumn{2}{|c|}{ Mérés } & \multicolumn{4}{|c|}{ Modell } \\
\hline & \multirow{2}{*}{$\begin{array}{c}\text { Külterület } \\
\text { (D-1 } \\
\text { állomás) } \\
94\end{array}$} & \multirow{2}{*}{$\begin{array}{c}\begin{array}{c}\text { Belterület } \\
(5-1\end{array} \\
\text { állomás) }\end{array}$} & \multicolumn{2}{|c|}{$\begin{array}{c}\text { Külterület } \\
\text { (D-1 } \\
\text { állomás) }\end{array}$} & \multicolumn{2}{|c|}{$\begin{array}{c}\text { Belterület } \\
\text { (5-1 } \\
\text { állomás) }\end{array}$} \\
\hline & & & 61 & $-35 \%$ & 98 & $+7 \%$ \\
\hline Hőségnapok $\left(\mathrm{T}_{\max }>30^{\circ} \mathrm{C}\right)$ & 34 & 30 & 11 & $-67 \%$ & 31 & $+3 \%$ \\
\hline Sörkerti napok $\left(\mathrm{T}_{20 \mathrm{~h}^{*}}>20^{\circ} \mathrm{C}\right)$ & 75 & 101 & 114 & $+52 \%$ & 140 & $+38 \%$ \\
\hline Nyári este $\left(T_{22 h^{*}}>20^{\circ} \mathrm{C}\right)$ & 43 & 77 & 72 & $+67 \%$ & 104 & $+35 \%$ \\
\hline Meleg éjszaka $\left(T_{\min }>17^{\circ} \mathrm{C}\right)$ & 30 & 64 & 34 & $+13 \%$ & 59 & $-8 \%$ \\
\hline Trópusi éjszaka $\left(T_{\min }>20^{\circ} \mathrm{C}\right)$ & 3 & 19 & 4 & $+33 \%$ & 16 & $-3 \%$ \\
\hline
\end{tabular}

*Közép-európai nyári idő 
A kül- és belterület között jelentkező elöjelellentét az éjszakai, minimum-hőmérsékleteket alkalmazó indexeknél szintén megmarad, csak az irányuk cserélődik fel (8.7. táblázat). Így, míg a külterületen felülbecslést, addig a belterületen alulbecslést állapíthatunk meg. Látható, hogy a külterület relatív eltérési már nem olyan magasak, mint a korábban ismertetett indexeknél. Éjszaka a modell jól láthatóan és helyes irányban mutatja a belterület és külterület közötti különbségek, habár a külterületi felülbecslés miatt ennek mértéket kisebbnek adja meg. Mindezek ellenére elmondható, hogy a városklíma vizsgálatok kulcsfontosságú időszakában a város területén a hőtöbblet jelenlegi és jövőbeli alakulásának tendenciájáról megfelelő kép adódik. Az időpontokhoz köthető klímaindexeknél (sörkerti napok és nyári esték) mind a külterületen, mind a belterületen jelentősebb felülbecslés mutatkozik, amelynek mértéke a belterületen kisebb, de meghaladja a 30\%-ot (8.7. táblázat). Ennek alapján az a következtetés vonható le, hogy a napnyugta után bekövetkező hủlés a modell szerint a kül- és belterületen is lassabban megy végbe, és míg a külterület esetében nem hül le a valóságnak megfelelő mértékben, addig a beépített területen megközelíti a helyes értéket (lásd éjszakai indexek).

Az eredmények alapján látható, hogy a városi területen belül is a beépítettség jellegétől (épületmagasság, szélesség) függően jelentős különbségek alakulhatnak ki akár a jelen, akár az elkövetkezendő időszakot tekintve. Fontos kiemelni, hogy a városi hötöbblet szempontjából releváns időszakot jellemző klímaindexek is azt mutatják, hogy a jövőben ez a höterhelés növekedni fog. Ez a tendencia föként a szigorúbb kritériummal jellemzett klímaindexeknél (nyári este, trópusi éjszaka) látványos, amelyek kapcsolatba hozhatók az hőhullámos időszakok kialakulásával, amikor az emberi szervezet jelentős hőterhelésnek van kitéve (7.3. fejezet, 7.4. ábra). Ezek alapján a lokális szintü intézkedéseknél célszerü a várostervezés folyamatában, illetve az adaptációs és mitigációs stratégiák kidolgozásában az épületek magasságának és a beépítés sủrüségének figyelembevétele. Gondolva itt arra, hogy a kompakt beépítés (LCZ 2 és 3) helyett célszerübb a nyitottat (LCZ 5 és 6) előnyben részesíteni, amelyen belül a magasságbeli különbség nem jelent nagyobb eltérést. Emellett természetesen elengedhetetlen a globális szintü összefogás annak érdekében, hogy az RCP8.5 szcenárió által felvázolt jövőkép ne valósulhasson meg.

Klímaindexek hasonló térbeli részletességü, városon belüli LCZ-k szerinti, 21. századi változásával összehasonlítható más eredményeket nehezen találhatunk. Bartholy et al. (2017) a déli és közép-európai régiókban vizsgálta a jövőben várható extrémumok változását, amelyek között a fagyos napok mellett az általam is vizsgált nyári napokat is elemezte az RCP szcenáriók alapján. Magyarország délkeleti részére a század közepén 10 és 20 nap közötti változást ad meg az 1981-2000 referencia időszakhoz viszonyítva és ebben a vizsgálatban sincs a szcenáriók között jelentős eltérés. A század végén azonban már lényeges eltérés lép fel és változás mértéke között 10 napos eltérés figyelhető meg (RCP4.5: 20-30 nap, RCP8.5: 30-40 nap). Bár e vizsgálat térbeli felbontása kisebb, a változás mértéke és iránya megegyező az eredményeimmel. Früh et al. (2011b) ugyancsak a MUKLIMO_3 modellel és a cuboid módszerrel vizsgálta a nyári, hőség- és sörkerti napok változását Frankfurtban. Munkájukban a változást a 2021-2050 és 19712000 időszakok között tekintették a régebbi A1B szcenárió és 4 klímamodell szimuláció kimenetei alapján. Eredményeik szerint a nyári napok változása 5-32, a hőségnapoké 316, míg a sörkerti napoké 4-29 között alakul a vizsgált területen, ahol az intervallumok szélességét a különböző szimulációk használata okozza. Az eltérő szcenárió és referencia időszak miatt ezek nehézkesen vethetők össze a dolgozatban bemutatott értékekkel, de annyi megállapítható, hogy a közeljövőre kapott eredményeim a megadott intervallumokon belül helyezkednek el. 


\section{9. Összegző gondolatok, kitekintés}

Munkám során térben és időben részletes mérési adatok és lokális skálájú városklíma modell felhasználásával elemeztem Szeged jelenkori és a jövőben várható városklimatológiai viszonyait. Vizsgálataimban a globális szintü felhasználásra kidolgozott lokális klímazónák (LCZ) rendszerét alkalmaztam. Ez az osztályozás lehetőséget teremt arra, hogy a vizsgálat során megállapított kapcsolatok és következtetések kivetíthetők legyenek más, hasonló földrajzi és éghajlati környezetben elhelyezkedő városokra. Eredményeim így nem csak Szegedre érvényesek, hanem regionálisan vagy akár globálisan is alapot teremthetnek összehasonlító elemzések készítésére, illetve alkalmazhatók a várostervezés folyamata során klímaadaptációs és mitigációs tervek készítéséhez.

Kutatásom a következő kérdésekre koncentrált: a léghőmérséklet zónák szerinti, illetve zónákon belüli elemzése; a hősziget térbeli és időbeli dinamikájának részletes feltárására; a vizsgálat kiterjesztése a felszínhőmérsékletre és az emberi szervezet hőterhelését számszerüsítő fiziológiailag ekvivalens hőmérsékletre (PET); a hőterhelés mértékének a 21. századra várható változásának szimulálása a MUKLIMO_3 modell, valamint egy dinamikai-statisztikai módszer alkalmazásával.

A lokális klímazónák közötti termikus különbségek megállapítása során a napi átlag-, és minimum-hömérséklet esetében egyértelmű tendencia volt felfedezhető. Ezeknek értékei a kompakt, magasabb beépítésủ zónák felöl a ritkább és alacsonyabb felé csökkennek. Ilyen egyértelmü összefüggés a maximum-hömérsékletek összehasonlításánál nem vehető észre. Tehát a nappal megjelenő hőmérséklet-különbség nem jelentős, így a klíma módosulásának városokat érintő vonatkozásainak elemzése során nem célszerü a nappali avagy a maximum-hőmérsékletekre koncentrálni. A zónák közötti legnagyobb különbségek a minimum értékeknél és a nyári évszakban fordulnak elő. Ezek alapján bebizonyult, hogy a beépítés legkarakteresebb hatása a termikus környezetre az éjszakai időszakban valósul meg. Így kiemelhető az éjszakai hőmérsékleti viszonyok részletes elemzésének fontossága, hiszen a város klímamódosító tulajdonságainak megértése csak ennek ismeretében lehetséges. Továbbá, e hatások klíma- vagy időjárás-előrejelző modellekbe történő beépítése esetén nagy hangsúlyt szükséges fektetni az éjszakai lehülést meghatározó folyamatok pontos közelítésére. Amennyiben a nyári ideális időjárású napokat vizsgáljuk, amikor a város termikus hatása a leginkább érvényesülni tud, a napszakok közül csak az éjszaka folyamán jelennek meg számottevő különbségek a zónák között. Ezek az ideális napok magában foglalják a hőhullámokkal jelzett időszakokat is, amikor rendkívül magas nappali hőmérsékletek lépnek fel. Az eredmények alapján elmondható, hogy ezen időjárási helyzetekben a városban tapasztalható magasabb éjszakai hőmérsékletek időben kiterjesztik a hőhullámok emberi szervezetre gyakorolt kellemetlen, megterhelő hatásait. A lokális klímazónákon alapuló elemzés alapján ez a kedvezőtlen körülmény kisebb mértékben érvényes a nyitottabb beépítés esetén, ami alapján e típusok preferálását szükséges szorgalmazni a várostervezés folyamata során. Ezáltal elkerülhető vagy csökkenthető lenne az éjszakai hőterhelés nagysága, ami az emberi szervezet regenerációját jelentős mértékben befolyásolja.

Ha az éjszakai hősziget intenzitást évszakok és zónák szerint tekintjük a teljes időszakot vizsgálva, a legnagyobb értékek a kompakt zónákat jellemzik és nyáron fordulnak elö. Ezzel szemben a legkisebb hőmérséklet-különbség az alig beépített LCZ 9-ben jelentkezik télen. Ideális napokon adott LCZ-ben az évszakok közötti eltérések kisebbek, mint az átlagos körülmények esetében, továbbá a legnagyobb és legkisebb intenzitást mutató évszak zónák szerint is változik. Az összefüggés rámutat arra, hogy a hőmérséklet-különbségek kialakulása nem feltétlenül az évszak, hanem inkább az ideális helyzet 
függvénye, azaz ezen körülmények között nem csak nyáron számíthatunk jelentős hőtöbbletre, ami télen kifejezetten elönyös lehet a fütési igény csökkenésével. Az egyes napszakok és évszakok közötti különbségek a kompakt beépítés esetében a legnagyobbak, míg az LCZ 9 értékei függenek a legkevésbé az adott időszaktól. Ez a megállapítás felhívja a figyelmet arra, hogy a zártabb zónák a város hatását a kritikus időszakokban erősítik, de a kedvezőtlen klimatikus hatások csökkennek más beépítések esetén, így például az LCZ 9 területén a hősziget intenzitás nagy mértékben mérséklődik.

A beépítés különbségeinek hatása az egyes klímaindexek vizsgálatakor is megjelenik. Eltérő tendenciák figyelhetők meg, ha ezeket két külön csoportja soroljuk aszerint, hogy elérnek vagy nem haladnak meg egy bizonyos küszöbértéket. Az előbbi, azaz a meleg indexek esetében a napok száma nő a külterületi LCZ D felől a beépített kompakt zónák felé haladva, míg a hideg indexek esetében ugyanebben az irányban csökken. Mindkét esetben a legnagyobb zónák közötti különbség a minimum-hőmérséklettel definiált indexeknél jelenik meg. Tehát ezek számában is tükröződnek a kompakt és nyitottabb beépítés között jelentkező különbségek, amelyek ebben az esetben is a meghatározó éjszakai időszakban jelennek meg. Az indexek vizsgálatának nagy előnye, hogy a napok számában kifejezett különbségek jobban érzékelhetők és jelentőségük könnyebben átadható, azaz érthetőbbek laikusok számára is, mint a ${ }^{\circ} \mathrm{C}$-ban kifejezett értékek.

A lokális klímazónákon belüli, azaz az állomások közötti különbségek vizsgálatára három zónában volt lehetőség (LCZ 5, 6 és 9). A nyári ideális napok vizsgálatánál számottevő intra-zonális különbségek éjszaka jelentek meg. Ezek az LCZ 5 és 9 esetében nem érték el az $1{ }^{\circ} \mathrm{C}$-ot, azonban az LCZ 6-ban az állomások közötti különbség már $1,5^{\circ} \mathrm{C}$ körüli. Ha az éjszakai, maximális hősziget intenzitást tekintjük, a legnagyobb különbség $\left(2{ }^{\circ} \mathrm{C}\right)$ az LCZ 6 esetében jelenik meg a nyári ideális napokon. Az állomások közötti eltérések a mikroskálájú környezet hatásainak vagy az uralkodó ÉNY széliránynak köszönhetök. Fontos kiemelni, hogy a zónákon belüli különbségek nem haladják meg a zónák között fellépőket. Ennek az jelentősége, hogy az egyes LCZ-k között kimutatott különbségek és összefüggések helytállóak, azaz általános érvényünek tekinthetők, illetve az esetleges bizonytalanság is minimalizálható.

A hősziget éjszakai dinamikáját évi átlagos körülmények között vizsgálva, a maximális intenzitás napnyugta után 2 órával jelenik meg, nagysága $2{ }^{\circ} \mathrm{C}$ a városközpontban. Ez a megállapítás alátámasztja a korábbi, hőszigettel foglalkozó vizsgálatok mobil mérések alapján kapott általános következtetéseit (pl. Sümeghy, Unger, 2003), azaz időben és térben részletesebb adatok felhasználásával alátámasztható e vizsgálatok érvényessége. Az éjszaka hátralévő részében az intenzitás állandó, jelentősebb csökkenése napnyugta után 10-11 órával kezdődik meg, majd a 12. és 13. órában teljesen megszünik. Ha ugyanezt ideális körülmények között tekintjük, a maximális intenzitás jóval magasabb, értéke $3,5^{\circ} \mathrm{C}$ és később, a napnyugtát követő 5 . órában következik be. Tehát a megfelelö feltételek következményeként fellépő hosszabb ideig tartó fejlödési folyamat elősegíti a nagyobb intenzitási értékek megjelenését. A jelentősebb leépülés ebben az esetben is a 10. órát követően jelenik meg és a 12-13. órában a hőmérséklet-különbségek elenyészők. A hősziget lokális klímazónák szerinti alakulását egy ideális nap éjszakáján vizsgáltam, ekkor intenzitása meghaladta az $5^{\circ} \mathrm{C}$-ot a kompakt zónák területén és az LCZ 5 központhoz közeli részein. Formája északnyugati irányba terjedt ki az LCZ 8 mentén, míg a város keleti és déli részein, leginkább az LCZ 6 és 9 területén a hőmérséklet-különbségek alacsonyabbak. Az LCZ 9 nyugatra fekvő területein egy jellegzetes hideg beáramlás figyelhető meg, ami kisebb hőmérséklet-különbségeket eredményez ezen a területen. Látható, hogy a kedvező beépítés a megfelelö körülmények között a höterhelés csökkentéséhez vezethet a helyi hatások érvényesülésének elősegítésével, így ebben a térségben optimális viszonyok alakíthatók ki. 
Az éjszakai hőmérsékleti gradiens ideális napokon történő vizsgálatakor megállapítható, hogy a legintenzívebb hülés napnyugatkor és az azt követő 1. órában következik be, azaz a hősziget kialakulásának szempontjából ez az időszak a legmaghatározóbb. Tehát, ha ezekben az órákban a megfelelő körülmények nem adottak (a szél megélénkül vagy a felhőborítottság megnő), akkor az éjjeli hősziget fejlődése nem biztosított. Ebben az időszakban a hülés mértéke egy óra alatt $2,5^{\circ} \mathrm{C}$ vagy afeletti a vidéki területen, a várost $2^{\circ} \mathrm{C}$ alatti érték jellemzi. Az elkövetkező órákban a hőmérsékleti gradiens értékei $0{ }^{\circ} \mathrm{C}$ körül alakulnak, nem történik számottevő változás sem a városi, sem a vidéki területeken. Azaz, ha ezekben az órákban esetlegesen a felhőzet megnövekszik, akkor már van egy kialakult termikus különbség, amit ez a folyamat nem módosít számottevően. Nagyobb különbségek a napnyugta utáni 10. órában, a melegedési folyamat kezdetekor jelennek meg. Eleinte a város értékei $0,5^{\circ} \mathrm{C}$, majd 1 és $1,5^{\circ} \mathrm{C}$ alattiak, vidéken pedig efölött alakulnak. Így, annak ellenére, hogy a vizsgálat fókuszában nem állt, egyértelmüen kimutatható az ún. hủvös sziget kialakulásának kezdeti folyamata az eltérő melegedési ütemek következtében.

A lokális klímazónák hőmérsékleti gradiensei közötti különbségek a napnyugta és napkelte időpontjában számottevők, e két időpont között minimálisak. Ez - párhuzamosan a korábbi megállapításokkal - azt mutatja, hogy a hősziget felépülését a beépítés szerinti hülési ütem eltérések okozzák, amelyek a kritikus időpontokban a legnagyobbak. A legnagyobb abszolút értékben tekintett óránkénti hőmérséklet-változás az alig beépített és természetes felszíneket érinti, míg a legkisebb a kompakt zónákban van jelen. A kompakt beépítés az említett 2 órában határozza meg a hősziget intenzitás maximumát, ezután a beépítés jellege számottevően nem befolyásoló tényező. Megállapítható, hogy a kevésbé beépített területek termikus viszonyai inkább a külterületekéhez hasonlít, amely tulajdonság a megterhelő, hőhullámos időszakban rendkívül kedvező lehet. A zónák között fellépő hőmérséklet-változás különbsége évi átlagban, valamennyi időjárási körülményt figyelembe véve $0,5^{\circ} \mathrm{C}$. Ez az eltérés, ha ideális időjárási körülményeket vizsgálunk, növekszik és mértéke eléri a $2{ }^{\circ} \mathrm{C}$-ot, míg a külön vizsgált nyári ideális nap éjszakáján már megközelíti a $3{ }^{\circ} \mathrm{C}$-ot. A különbségek kiemelik az időjárási helyzetek szerepének fontosságát a hősziget kialakulásának és nagyságának szempontjából, amelyek az egyes gradiensek értékein keresztül még hangsúlyosabban megmutatkoznak.

A lokális klímazónák koncepcióját eredetileg a léghőmérsékletre dolgozták ki, azonban a városban megjelenő hőtöbblet nem csak a tetőrétegben, hanem a felszínen is jelentkezik. Következésképpen érdemes volt megvizsgálni, hogy a zónák miképpen befolyásolják a felszínhőmérséklet értékeit, amelyet a teljes felszínre és külön a földfelszínre (az épületek tetejének elhanyagolásával) tekintettem. Ennek során a léghőmérséklet esetén érvényes LCZ sorrendet sikerült megállapítani a felszínhőmérséklet esetében is, ami utóbbi esetben jelenik meg legtisztábban. Ez alapján a legmagasabb értékek a beépített zónák közül a kompakt LCZ-kben, majd azt követően az LCZ 5 területén fordulnak elö, míg a legkisebbek az LCZ 9-ben. A sorrendben az LCZ 8 értékei megelőzik az LCZ 6ét, ami köszönhető a vízzáró felszín nagyobb arányának és az épületek esetében a lapos tető könnyebb felmelegedésének. Az LCZ-k felszínhőmérséklet értékeinek sorrendje mellett megállapítható, hogy a kompakt zónák felől a természetesebb felszínek felé haladva kevésbé gyakoribb egy tipikus érték, azaz nagyobb a zónákon belüli változékonyság. Vizsgálatunk úttörő jellegünek tekinthető, hiszen ilyen irányú vizsgálat korábban nem volt, ugyanakkor manapság már jelennek meg hasonló eredmények (Geletic et al., 2016b; Cai et al., 2017). Ez fontos elörelépésnek tekinthetö, ugyanis az LCZ ilyen irányú kiterjesztése megerősíti e termikus alapú koncepció hasznosságát és bemutatja, hogy bár a rendszert nem erre dolgozták ki, ebben a viszonylatban is müködik, ilyen célokra is használható. Ráutal arra, hogy a város modellezésénél a klímazónák rendszere alkalmas 
az eltérő felszínnek klímamódosító sajátosságainak visszaadására, hiszen nem csak a léghömérsékletre, hanem erre az állapothatározóra is reprezentatív.

Az említett hőmérséklet értékek mellett vizsgáltam a lokális klímazónák szerinti humán komfort viszonyokat a kültéri tevékenységeknek kedvező zónák megállapítása érdekében, évi és évszakos vonatkozásban. Hasonlóan a korábbiakhoz, a PET értékei a kompakt zónák felől a ritkább beépítés felé haladva csökkennek évszaktól és napszaktól függetlenül. A kültéri tevékenységeknek leginkább kedvező zónák nappal az LCZ 6 és 9, míg este az LCZ 2 és 3 . A hőérzeti osztályokat tekintve a „hideg” kategóriák a kevésbé, a „meleg” kategóriák a sürün beépített zónákban a leggyakoribbak. Az eredmények rámutatnak arra, hogy az LCZ-k sémája a humánkomfort viszonyok esetében is müködöképes.

Az átmeneti évszakokat vizsgálva a kültéri tevékenységeknek kedvező időszak hoszszabb a sürübben beépített zónákban, mint természetes felszíneken. Tavasszal, a kora délutáni napszakot vizsgálva a kellemes hőérzet zónától függően március végén, április elején kezdődik és május elejéig tart. Ez ősszel már az évszak elejétől kezdődően érvényes és október közepéig-végéig tart. Ha a napnyugta utáni, kora esti időszakot vizsgáljuk, akkor tavasszal a kedvező időszak a beépített zónákban már március közepétől, a természetes felszínek esetében 3 héttel később kezdődik. Összel a természetes zónák csak szeptember végéig kedvezők, míg a beépítettek október elejéig. Nyáron, a kora délutánt tekintve egyik zóna sem alkalmas kültéri tevekénységre a magas höterhelés miatt, de az esti időszakban valamennyi megfelel ennek, amelyek közül is a beépített zónák az igazán kedvezők. Hőhullámmal jellemzett időszak esetében nappal 6-8 órán keresztül a város teljes lakossága jelentős hőstressznek van kitéve. Összességében megállapítható, hogy a Szegedhez hasonló klímájú városok esetében az átmeneti évszakok és a nyár este is kedvező a kültéri tevékenységeknek. A tavasszal és ősszel a beépített területeket jellemző hosszabb kedvező kültéri időszak a városi tevékenységek népszerüségét mozdítja elő, ami fontos szempont a városi turizmus szempontjából is. Az ilyen irányú vizsgálat fö jelentősége, hogy a laikusok számára a hőérzet kategorizálásán keresztül olyan következtetések vonhatók le, amelyek eredményei könnyen kommunikálhatók a döntéshozók irányába is.

Lokális skálájú modell alkalmazásával vizsgáltam a hőterhelést jellemző klímaindexek városon belüli és akörüli időbeli változását részletes térbeli felbontásban. A város egyes területei között már a jelen időszakban is jelentős különbségek alakulnak ki az indexek területi eloszlásában, a napok száma a sürübben beépített zónák felé növekszik, mutatva a megnövekedett hőterhelést, ahogy erre a korábbi mérési eredmények is rámutattak. Vizsgálataim alapján valamennyi index száma növekedni fog a jövőben a beépített területek és a természetes felszínek esetében is. Ez a változás a közeljövőben (20212050) még nem látványos mértékü, de már megjelenik, noha az optimistább és pesszimistább szcenárió között elenyésző a különbség. A század végén, azaz a 2071-2100 időszakban már az RCP4.5 szerint is számottevő változások várhatók, amelyek az RCP8.5 esetében sokkal drasztikusabb mértéküek. Az indexek közül a legnagyobb változás azokat érinti, amelyeknek kritériuma szigorúbb, gondolva itt a nyári estékre és a trópusi éjszakákra. Ezek esetében a hőterhelés növekedése jelentős mértékűnek tekinthető és öszszefüggésbe hozható a hőhullámos időszakok gyakoribb kialakulásával, amikor a korábban bemutatott hőérzet vizsgálatok alapján az emberi szervezet jelentős hőterhelésnek van kitéve, zónától függetlenül. Külön kiemelhető a trópusi éjszakák látványos változása, hiszen míg a jelenben leginkább csak a hőhullámos időszakok pár napján voltak jellemzők, addig a pesszimistább jövőkép szerint a század végére számuk átlagosan meghaladhatja az egy hónapot. Az indexek értékeinek jövőbeli emelkedéséhez a beépítés sürüségének növekedése további napokat ad hozzá. Ez a tendencia a jelenben még nem nagy 
mértékü, de a jövőben az általánosan megnövekedö terheléshez ad még további többletet. Ezek alapján - a klímaváltozás hatásának mérséklése szempontjából - kedvezőtlen a sürü beépítés, inkább a nyitottabbat kellene elönybe részesíteni.

A modell eredményeit mérésekkel összehasonlítva megállapítható, hogy pontosabb becslést ad a városi területeken, mint a külterületen. A leginkább helytálló eredmények a minimum- és maximum-hömérséklet alapú klímaindexek esetében jelennek meg. Következésképpen, a város termikus hatása szempontjából fontos időszakban, azaz éjszaka az eredmények a városi területen megbízhatók. Az időponttal definiált indexek esetében mind külterületen, mind belterületen bizonyos felülbecslés figyelhető meg, ami arra enged következtetni, hogy a modellben az éjszakai lehülés mindkét helyen később következik be. Tehát a modell alkalmas az éjszakai városi hőterhelés megadására, ami alátámasztja a megfogalmazott következtetéseket, így a várható alakulás megállapításai helytállónak tekinthetők.

Összegezve a korábbiakat, elmondható, hogy a léghőmérséklet, a felszínhőmérséklet és a hőérzet esetében is érvényes az LCZ-k megalkotásának eredeti koncepciója és a klímamodellezés esetében is alkalmas a felszín leírására. Az egyes zónák sorrendje sorszámukat követi, leszámítva az LCZ 8-at, ami az LCZ 6-ot megelőzi. Tehát az eredmények alapján rámutattam, hogy várostervezési szempontból éghajlati zónánkban a hőterhelés mérséklése céljából a ritkább beépítést szükséges szorgalmazni a kompakttal szemben. Ez a megfontolás egyre inkább indokolttá válik, hiszen az eleve jelenlévő városi hőtöbblet mellett nem szabad megfeledkeznünk a globális klímaváltozás problémaköréröl. Továbbá a városi népesség jövőbeni növekedése miatt is elengedhetetlen lépés a hötöbblet mérséklésének megvalósítása. Vizsgálatom eredményei segíthetik a döntéshozók és várostervezők munkáját, hozzájárulva az élhetőbb városok kialakításához, amelyekre a jövőben egyre inkább szükségünk lesz.

Kutatásom során a város termikus hatását elősegítő körülmények időszakaiban is vizsgáltam a lokális klímazónák jellemzőit. A továbbiakban mindenképpen érdemes lenne az egyes időjárási elemek hatását külön-külön elemezni városklimatológiai hatásuk vonatkozásában. Ezeknek a legnagyobb szerepe az éjszakai hősziget kialakulásának folyamatában jelenhet meg és a hőmérsékleti gradiensek alakulásában tükröződhet leginkább. Ennek köszönhetően a beépítés további hatásai ismerhetők meg, függően pl. a szélsebesség vagy felhőborítottság különböző értékeitöl.

A városklíma modellezése esetében érdemes lehet idealizált, kitalált helyzeteket szimulálni a beépítés jellegét illetően, aminek köszönhetően különböző várostervezési opciók hatásai vizsgálhatók. Ez alapján ajánlások fogalmazhatók meg a fenntartható klímastratégiák vonatkozásában. A klímaindexek mellett a modellezés egy másik további vizsgálható eleme lehet a PET jövőbeli alakulásának szimulálása is. A hőérzeti kategóriák jövőben várható változásainak elemzése hozzájárulhat a klímaváltozás egy újabb vonatkozásának megismeréséhez. 


\section{Irodalomjegyzék}

Alexander PJ, Mills G, 2014: Local climate classification and Dublin's urban heat island. Atmosphere, 5 , 755-774.

Ali-Toudert F, 2005: Dependence of the outdoor thermal comfort on street design in hot and dry climate. Ber Meteor Inst Albert-Ludwigs-Univ Freiburg, 15, 224 p.

Andrade H, Alcoforado L-J, 2008: Microclimatic variation of thermal confort in a district of Lisbon (Telherias) at night. Theor Appl Climatol, 92, 225-237.

Arnfield J, Herbert JM, Johnson GT, 1998: A Numerical Simulation Investigation of Urban Canyon Energy Budget Variations. in Proceedings of 2nd AMS Urban Environment Symposium

Auer AH, 1978: Correlation of land use and cover with meteorological anomalies, J App Meteorol, 17, 636-643.

Azevedo JA, Chapman L, Muller CL, 2016: Quantifying the daytime and night-time urban heat island in Birmingham, UK: A comparison of satellite derived land surface temperature and high resolution air temperature observations. Remote Sens, 8(2), paper 153

Bader DC, Covey C, Gutowski WJ, Held IM, Kunkel KE, Miller RL, Tokmakian RT, Zhang MH, 2008: Climate models: An assessment of strengths and limitations. A Report by the U.S. Climate Change Science Program and the Subcommittee on Global Change Research. Department of Energy, Office of Biological and Environmental Research, Washington, D.C. 124 p.

Balázs B, Unger J, Gál T, Sümeghy Z, Geiger J, Szegedi S, 2009: Simulation of the mean urban heat island using 2D surface parameters: empirical modeling, verification and extension. Meteorol Appl, 16, 275287.

Banon L, Hernandez E, 2013: Spatial layout of forecasted extreme temperatures in the city of Murcia (Spain). Tethys: J Mediterr Meteorol Climatol, 10, 3-12.

Bartholy J, Pongrácz R (eds.), 2013: Klímaváltozás. Elektronikus könyv. 180 p.

Bartholy J, Pongrácz R, Pieczka I, Kelemen FD, Kis A, André K, 2015: Regional climate model experiment using RegCM subgridding options in the framework of Med-CORDEX. In Proceedings, 95th AMS Annual Meeting. Phoenix, AZ. Paper 591, 6 p.

Bartholy J, Pongrácz R, Pieczka I, André K, 2017: Decadal anaylis of future extreme climatic conditions in southern and central European regions. In Proceedings, 97th AMS Annual Meeting. Seattle, Washington. Paper 546, $6 \mathrm{p}$.

Basara JB, 2008: The Oklahoma City Micronet Project. International Association for Urban Climate Newsletter 27, 10-12.

Basara JB, Basara HG, Illston BG, Crawford, KC, 2010: The impact of the urban heat island during an intense heat wave in Oklahoma City. Adv Meteorol, 2010, 10 p.

Basara JB, Illston BG, Fiebrich CA, Browder PD, Morgan CR, McCombs A, Bostic JP, McPherson RA, Schroeder AJ, Crawford KC, 2011: The Oklahoma city micronet. Meteorol Appl, 18, 252-261.

Bassett R, Cai, X, Chapman L, Heaviside C, Thornes JE, Muller CL, Young DT, Warren EL, 2016: Observations of urban heat island advection from a high-density monitoring network. Q J Roy Meteorol Soc, 142, 2434-2441.

Bechtel B, Alexander PJ, Böhner J, Ching J, Conrad O, Feddema J, Mills G, See L, Stewart I, 2015: Mapping local climate zones for a worldwide database of the form and function of cities. ISPRS Int $\mathbf{J}$ Geo-Inf, 4(1), 199-219.

Błażejczyk K, 2002. Znaczenie czynników cyrkulacyjnych i lokalnych w kształtowaniu klimatu i bioklimatu aglomeracji warszawskiej. Dokumentacja Geograficzna, vol. 26, Warszawa: Instytut Geografii i Przestrzennego Zagospodarowania PAN.

Boo K-O, Oh S-N, 2000: Characteristics of spatial and temporal distribution of air temperature in Seoul (in Korean). J Korean Meteor Soc, 36, 499-506.

Bottyán Z, Unger J, 2003: A multiple linear statistical method for estimating mean maximum urban heat island. Theor Appl Climatol, 75, 233-243.

Brousse O, Martilli A, Foley M, Mills G, Bechtel B, 2016: WUDAPT, an efficient land use producing data tool for mesoscale models? Integration of urban LCZ in WRF over Madrid. Urban Clim, 17, 116-134.

Brown MJ, 2000: Urban parameterizations for mesoscale meteorological models. In: Boybeyi Z (ed.) (193255). Mesoscale atmospheric dispersion. Wessex Press, $448 \mathrm{p}$.

Bruse M, 1995: Development of a microscale model for the calculation of surface temperatures in structured terrain. MSc Thesis, Inst. for Geography, Univ. Bochum

Bruse M, 2004: ENVI-met 3.0: updated model overview. University of Bochum. www. envi-met. com.

Bruse M, Fleer H, 1998: Simulating surface-plant-air interactions inside urban environments with a three dimensional numerical model. Environ Modell Softw, 13, 373-384. 
Buchholz S, Kossmann M, 2015: Research note. Visualisation of summer heat intensity for different settlement types and varying surface fraction partitioning. Landscape Urban Plan, 144, 59-64.

Busch P, Kuttler W, 1990: Klimatologie. Ferdinand Schöningh, Padeborn-Müchen-Wien-Zürich, 96 p.

Cai M, Ren $C, X u$ Y, Lau KKL, Wang R, 2017: Investigating the relationship between local climate zone and land surface temperature using an improved WUDAPT methodology-A case study of Yangtze River Delta, China. Urban Clim, http://dx.doi.org/10.1016/j.uclim.2017.05.010

Chandler TJ, 1965: The Climate of London. Hutchinson, 292 p.

Chang B, Wang H-Y, Peng T-Y, Hsu Y-S, 2010: Development and evaluation of a city-wide wireless weather sensor network. Edu Technol Soc, 13, 270-280.

Chapman L, Muller CL, Young DT, Warren EL, Grimmond CSB, Cai X-M, Ferranti EJS, 2015: The Birmigham Urban Climate Laboratory: An open meteorological test bed and challanges of the smart city. Bull Am Meteorol Soc, 96, 1545-1560.

Chen F, et al., 2011: The integrated WRF/urban modelling system: development, evaluation, and applications to urban environmental problems. Int J Climatol, 31(2), 273-288.

Christensen JH, Christensen OB, 2003: Severe summertime flooding in Europe. Nature 421, 805-806.

Christensen JH, Christensen OB, 2007: A summary of the PRUDENCE model projections of changes in European climate by the end of this century. Climatic Change, 81, 7-30.

Christensen OB, Christensen JH, Machenhauer B, Botzet M, 1998: Very high-resolution regional climate simulations over Scandinavia - Present climate. J Climate, 11, 3204-3229.

Christensen JH, Carter TR, Rummukainen M, Amanatidis G, 2007: Evaluating the performance and utility of regional climate models: the PRUDENCE project. Climatic Change, 81, 1-6.

Collins WD, Blackmon ML, Bonan GB, Hack JJ, Henderson TB, Kiehl JT, Large WG, McKenna DS, 2006: The Community Climate System Model version 3 (CCSM3). J Climate, 19, 2122-2143.

Davies L, et al., 2011: Open Air Laboratories (OPAL): A community-driven research programme. Environ Pollut, 159, 2203-2210.

Dabberdt W, Koistinen J, Poutiainen J, Saltikoff E, Turtiainen H, 2005: The Helsinki mesoscale testbed: an invitation to use a new 3-D observation network. Bull Am Meteorol Soc, 86, 906-907.

de Dear R, Pickup J, 2000: An Outdoor Thermal Environment Index (OUT_SET*) - Part II - Applications. In de Dear R, Kalma J, Oke T, Auliciems A (eds): Biometeorology and Urban Climatology at the Turn of the Millenium. Selected Papers from the Conference ICB-ICUC'99 (Sydney, 8-12 Nov. 1999). WMO, Geneva, WCASP-50, 258-290.

De Ridder K, Lauwaet D, Maiheu B, 2015: UrbClim-A fast urban boundary layer climate model. Urban Clim, 12, 21-48.

Déqué M, Piedelievre JP, 1995: High-resolution climate simulation over Europe. Clim Dyn, 11, 321-339.

Dickinson RE, Oleson KW, Bonan G, Hoffman F, Thornton P, Vertenstein M, Yang Z-L, Zeng X, 2006: The Community Land Model and its climate statistics as a component of the Community Climate System Model. J Climate, 19, 2302-2324.

Duckworth FS, Sandberg JS, 1954: The effect of cities upon horizontal and vertical temperature gradients. Bull Am Meteorol Soc, 35, 198-207.

Dufresne J-L, et al., 2013: Climate change projections using the IPSL-CM5 Earth System Model: from CMIP3 to CMIP5. Clim Dynam, 40(9-10), 2123-2165.

Égerházi LA, Gál T, 2012: Assessment of the bioclimatic conditions of a popular playground by the microclimate model ENVI-met. Acta Climatologica et Chorologica, 46, 107-114.

Égerházi LA, Kántor N, Gál T, 2013: Evaluation and modelling the micro-bioclimatological conditions of a popular playground in Szeged, Hungary. Int Rev Appl Sci Eng, 4(1), 57-61.

Ehret U, Zehe E, Wulfmeyer V, Warrach-Sagi K, Liebert J, 2012: Should we apply bias correction to global and regional climatemodel data? Hydrol Earth Syst Sci, 16, 3391-3404.

Ehrhard J, Khatib IA, Winkler C, Kunz R, Moussiopoulos N, Ernst G, 2000: Themicroscale model MIMO: development and assessment. J. Wind Eng Ind Aerodyn, 85, 163-176.

Eliasson I, 1992: Infrared termography and urban temperature patterns. Int J Rem Sens, 13, 869-879.

Eliasson I, Holmer B, 1990: Urban heat island circulation in Göteborg, Sweden. Theor Appl Climatol, 42, 187-196.

Ellefsen R, 1991: Mapping and measuring buildings in the urban canopy boundary layer in ten US cities. Energ Build, 15-16, 1025-1049.

Falkenberg G, Bolz HM, 1949: Neue Bestimmung der Konstanten der Angströmschen Strahlungsformel. Meteorol Z, 3, 97.

Fanger PO, 1972: Thermal Comfort. McGraw Hill Book Co., New York, USA, 244 p.

Fenner D, Meier F, Scherer D, Polze A, 2014: Spatial and temporal air temperature variability in Berlin, Germany, during the years 2001-2010. Urban Clim, 10, 308-331. 
Fenner D, Meier F, Bechtel B, Otto M, Scherer D, 2017: Intra and inter 'local climate zone'variability of air temperature as observed by crowdsourced citizen weather stations in Berlin, Germany. Meteorol Z, $26,525-547$.

Formayer H, Haas P, 2009: Correction of RegCM3 model output data using a rank matching approach applied on various meteorological parameters. In: Deliverable D3.2 RCM output localization methods (BOKU-contribution of the FP 6 CECILIA project), 5-15.

Früh B, Becker P, Deutschländer T, Hessel JD, Kossmann M, Mieskes I, Namyslo J, Roos M, Sievers U, Steigerwald T, Turau H, Wienert U, 2011a: Estimation of climate-change impacts on the urban heat load using an urban climate model and regional climate projections. J Appl Meteorol Climatol, 50, 167-184.

Früh B, Kossmann M, Roos M, 2011b: Frankfurt am Main im Klimawandel - Eine Untersuchung zur stadtischen Warmebelastung. Berichte des Deutschen Wetterdienstes 237. Selbstverlag des Deutschen Wetterdienstes, Offenbach am Main, 68 p.

Gagge AP, Stolwijk JAJ, Nishi Y, 1971: An effective temperature scale based on a simple model of human physiological regulatory response. ASHRAE Trans 77, 247-262.

Gál T, Bechtel B, Lelovics E, Unger J, 2015: Comparison and integration of LCZ classification methods based remote sensing and GIS. Nineth Int. Conf. on Urban Climatology, ICUC-9, Toulouse, France.

Gál T, Skarbit N, Unger J, 2016: Urban heat island patterns and their dynamics based on an urban climate measurement network. Hung Geogr Bull, 65(2), 105-116.

Geletič J, Lehnert M, Dobrovolný P, 2016a: Modelled spatio-temporal variability of air temperature in an urban climate and its validation: a case study of Brno, Czech Republic. Hung Geogr Bull, 65(2), 169180.

Geletič J, Lehnert M, Dobrovolný P, 2016b: Land surface temperature differences within local climate zones, based on two central European cities. Remote Sens, 8(10), 788.

Geletič J, Lehnert M, Savić S, Milošević D, 2018: Modelled spatiotemporal variability of outdoor thermal comfort in local climate zones of the city of Brno, Czech Republic. Sci Total Environ, 624, 385-395.

Giannopoulou K, Livada I, Santamouris M, Saliari M, Assimakopoulos M, Caouris YG, 2011: On the characteristics of the summer urban heat island in Athens, Greece. Sustain Cities Soc, 1(1), 16-28.

Giorgetta MA, et al., 2013: Climate and carbon cycle changes from 1850 to 2100 in MPI-ESM simulations for the Coupled Model Intercomparison Project phase 5. J Adv Model Earth Syst, 5(3), 572-597.

Giorgi F, Mearns LO, 1991: Approaches to the simulation of regional climate change - A review. Rev Geophys, 29, 191-216.

Goddess C. (ed.) 2005: STARDEX: Downscaling climate extremes. STARDEX Final Report. Climatic Research Unit, University of East Anglia, Norwich, UK. http://www.cru.uea.ac.uk/projects/stardex/reports/STARDEX_FINAL_REPORT.pdf, 24 p.

Göndöcs J, Breuer H, Pongrácz R, Bartholy J, 2017: Urban heat island mesoscale modelling study for the Budapest agglomeration area using the WRF model. Urban Clim, 21, 66-86.

Grimmond CSB, Oke TR, 1999: Aerodynamic properties of urban areas derived from analysis of surface form. J Appl Meteorol, 38, 1262-1292.

Grimmond CSB, 2006: Progress in measuring and observing the urban atmosphere. Theor Appl Climatol, $84(1-3), 3-22$.

Grimmond CSB, Oke TR, 2002: Turbulent heat fluxes in urban areas: Observations \& local-scale urban meteorological parameterization scheme (LUMPS). J Appl Meteor, 41, 792-810.

Grimmond CSB, Cleugh HA, Oke TR, 1991: An objective urban heat storage model and its comparison with other schemes. Atmos Environ, 25B, 311-326.

Gross G, 1989: Numerical simulation of the nocturnal flow systems in the Freiburg area for different topographics. Beitr Physik Atmos, 62, 57-72.

Gross G, 1991: Anwendungsmöglichkeiten mesoskaliger Simulationsmodelle dargestellt am Beispiel Darmstadt. Meteorol Rundsch, 43, 97-112.

Gulyás Á, Unger J, Matzarakis A, 2006: Assessment of the microclimatic and human comfort conditions in a complex urban environment: modelling and measurements. Build Environ, 41, 1713-1722.

Halenka T, 2007: CECILIA keeping a close eye on climate change. eStrategies, Science, Technology and Innovation Projects, British Publishers, 12.

Hanson CE, et al., 2007: Modelling the impact of climate extremes: an overview of the MICE project. Climatic Change, 81, 163-177.

Hamdi R, Masson V, 2008: Inclusion of a drag approach in the Town Energy Balance (TEB) scheme: Offline 1D evaluation in a street canyon. J Appl Meteorol Climatol, 47(10), 2627-2644.

Harman IN, Barlow J, Belcher S, 2004a: Scalar fluxes from urban street canyons part II: model. BoundLayer Meteorol, 113, 387-410. 
Harman IN, Best MJ, Belcher SW, 2004b: Radiative exchange in an urban street canyon. Bound-Layer Meteorol, 110, 301-16.

Hazeleger W, et al., 2010: EC-Earth: a seamless earth-system prediction approach in action. Bull Am Meteorol Soc, 91(10), 1357-1363.

Heus T, van Heerwaarden CC, Jonker HJJ, Pier Siebesma A, Axelsen S, van den Dries K, Geoffroy O, Moene AF, Pino D, de Roode SR, Vilà-Guerau de Arellano J, 2010: Formulation of the Dutch Atmospheric Large-Eddy Simulation (DALES) and overview of its applications. Geosci Model Dev, 3, 415444.

Heusinkveld BG, Steeneveld GJ, van Hove LWA, Jacobs CMJ, Holtslag AAM, 2014: Spatial variability of the Rotterdam urban heat island as influenced by urban land use. J Geophys Res, 119, 677-692.

Hidalgo J, Masson V, Baklanov A, Pigeon G, Gimeno L, 2008: Advances in urban climate modeling. Annals of the New York Academy of Sciences, 1146(1), 354-374.

Hong J-W, Hong J, Lee S-E, Lee, J, 2013: Spatial Distribution of urban heat island based on local climate zone of automatic weather station in Seoul metropolitan area. Atmosphere. Korean Meteorol Soc, 23: 413-424.

Honjo T, Yamato H, Mikami T, Grimmond CSB, 2015: Network optimization for enhanced resilience of urban heat island measurements. Sustain Cities Soc, 19, 319-330.

Houghton JT, Ding Y, Griggs DJ, Noguer M, van der Linden PJ, Dai X, Maskell K, Johnson CA, 2001: Climate Change 2001: The Scientific Basis. Cambridge UniversityPress, $881 \mathrm{p}$.

Höppe P, 1984: Die Energiebalanz des Menschen. Dissertation. Wissenschaftlicher Mitteilung 49 Universität München, $171 \mathrm{p}$.

Höppe P, 1985: Anwendungsmöglichkeiten eines instationären Energiebilanzmodells zur Bewertung der thermischen Behaglichkeit. Ann Meteorol, 22, 17-18.

Höppe P, 1992: Ein neues Verfahren zur Bestimmung der mittleren Strahlungstemperatur in Freien. Wetter und Leben, 44, 147-151.

Höppe P, 1993: Heat balance modelling. Experientia, 49, 741-746.

Höppe P, 1999: The physiological equivalent temperature - a universal index for the biometeorological assessment of the thermal environment. Int J Biometeorol, 43, 71-75.

Höppe P, 2002: Different aspects of assessing indoor and outdoor thermal comfort. Energy Build, 34, 661665.

Hung TK, Wo OC, 2012: Development of a community weather information network (Co-WIN) in Hong Kong. Weather, 67, 48-50.

Ihara T, Genchi Y, Sato T, Yamaguchi K, Endo Y, 2008: City-block-scale sensitivity of electricity consumption to air temperature and air humidity in business districts of Tokyo, Japan Appl Energy, 33, 1634-1645.

IPCC 1992: Climatic Change 1992: Report prepared for Intergovernmental Panel on Climate Change by Working Group I combined with Supporting Scientific Material, Cambridge University Press, Cambridge, Great Britain, New York, NY, USA, and Victoria, Australia, 218 p.

IPCC 2001: Climate Change 2001: The Scientific Basis. Contribution of Working Group I to the Third Assessment Report of the Intergovernmental Panel on Climate Change. Cambridge University Press, Cambridge, UK and New York, NY, USA, 881p.

IPCC 2007: Climate Change 2007. The Scientific Basis, Contribution of Working Group I to the Fourth Assessment Report of the Intergovernmental Panel on Climate Change. Cambridge University Press, Cambridge, UK and New York, NY, USA, 946p.

IPCC 2013: Climate change 2013: the physical science basis: Working Group I contribution to the Fifth assessment report of the Intergovernmental Panel on Climate Change. Cambridge University Press, Cambridge, UK and New York, NY, USA, 1535 p.

Jacob D, et al., 2007: An inter-comparison of regional climate models for Europe: design of the experiments and model performance. Climatic Change, 81, 31-52.

Jacob D, Kotova L, Lorenz P, Moseley C, Pfeifer S, 2008: Regional climate modelling activities in relation to the CLAVIER project. Időjárás, 112, 141-153.

Jacob D, et al., 2014: EURO-CORDEX: new high-resolution climate change projections for European impact research. Reg Environ Change, 14, 563-578.

Jänicke B, Meier F, Fenner D, Fehrenbach U, Holtmann A, Scherer D, 2017: Urban-rural differences in near-surface air temperature as resolved by the Central Europe Refined analysis (CER): sensitivity to planetary boundary layer schemes and urban canopy models. Int J Climatol, 37(4), 2063-2079.

Järvi L, Grimmond CSB, Christen A, 2011: The Surface Urban Energy and Water Balance Scheme (SUEWS): evaluation in Los Angeles and Vancouver. J Hydrol, 411, 219-237. 
Jendritzky G, Sönning W, Swantes HJ, 1979: Ein objektives Bewertungsverfahren zur Beschreibung des thermischen Milieus in der Stadt- und Landschaftsplanung (Klima-Michel-Modell). ARL Beiträge $28,85 \mathrm{p}$.

Jendritzky G, Menz H, Schirmer H, Schmidt-Kessen W, 1990: Methodik zur raumbezogenen Bewertung der thermischen Komponente im Bioklima des Menschen (Fortgeschriebenes Klima- Michel-Modell). Beitr Akad Raumforsch Landesplan, 114.

Jendritzky G, Staiger H, Bucher K, Graetz A, Laschewski G, 2000: The Perceived Temperature - The Method of the Deutscher Wetterdienst for the Assessment of Cold Stress and Heat Load for the Human Body. Internet Workshop on Windchill, hosted by Environment Canada, April 3-7, 2000.

Lindberg F, Holmer B, Thorsson S, 2008: SOLWEIG 1.0 - modelling spatial variations of 3D radiant fluxes and mean radiant temperature in complex urban settings. Int. J. Biometeorol. 52, 697-713.

Johnson DB, 1985: Urban modification of diurnal temperature cycles in Birmingham. J Climatol, 5, 221225.

Johnson GT, Oke TR, Lyons TJ, Steyn DG, Watson ID, Voogt JA, 1991: Simulation of Surface Urban Heat Islands under 'Ideal' Conditions at Night. Part I: Theory and Tests Against Field Data, BoundLayer Meteorol, 56, 275-294.

Jones C, et al., 2011: The HadGEM2-ES implementation of CMIP5 centennial simulations. Geoscient Model Develop, 4(3), 543-570.

Kántor N, Unger J, Gulyás Á, 2012: Subjective estimation of thermal environment in recreational urban spaces-Part 2: international comparison. Int J Biometeorol, 56, 1089-1101.

Kántor N, Kovács A, Takács Á, 2016: Seasonal differences in the subjective assessment of outdoor thermal conditions and the impact of analysis techniques on the obtained results. Int J Biometeorol, 60, $1615-1635$.

Kántor N, Gál CV, Gulyás Á, Unger J, 2018: The impact of façade orientation and woody vegetation on summertime heat stress patterns in a Central-European square-comparison of radiation measurements and simulations. Adv in Meteorol, https://doi.org/10.1155/2018/2650642

Kikegawa Y, Genchi Y, Yoshikado Y, Kondo H, 2003: Development of a numerical simulation system for comprehensive assessments of urban warming countermeasures including their impacts upon the urban buildings' energy-demands. Appl Energy, 76, 449-466.

Kikegawa Y, Genchi Y, Kondo H, Hanaki K, 2006: Impacts of city-block-scale countermeasures against urban heat-island phenomena upon a building's energy-consumption for air-conditioning. Appl Energy, 83, 649-668.

Kikegawa Y, Tanaka A, Ohashi Y, Ihara T, Shigeta Y, 2014: Observed and simulated sensitivities of summertime urban surface air temperatures to anthropogenic heat in downtown areas of two Japanese Major Cities, Tokyo and Osaka. Theor Appl Climatol, 117, 175-193.

Kim YH, Baik JJ, 2005: Spatial and temporal structure of the urban heat island in Seoul. J Appl Meteorol, 44(5), 591-605.

Knez I, Thorsson S, 2006: Influences of culture and environmental attitude on thermal, emotional and perceptual evaluations of a public square. Int J Biometeorol, 50, 258-268.

Kondo H, Kikegawa Y, 2003: Temperature variation in the urban canopy with anthropogenic energy use. Pure Appl Geophys, 160, 317-324.

Kondo H, Liu FH, 1998: A study on the urban thermal environment obtained through one-dimensional urban canopy model. J Japan Soc Atmos Environ, 33, 179-192.

Kondo H, Genchi Y, Kikegawa Y, Ohashi Y, Yoshikado H, Komiyama H, 2005: Development of a multilayer urban canopy model for the analysis of energy consumption in a big city: Structure of the urban canopy model and its basic performance. Bound-Layer Meteorol, 116(3), 395-421.

Konstantinov PI, Varentsov MI, Malinina EP, 2014: Modeling of thermal comfort conditions inside the urban boundary layer during Moscow's 2010 summer heat wave (case-study). Urban Clim, 10(3), 563-572.

Koskinen JT, et al., 2011: The Helsinki testbed: A mesoscale measurement, mesearch and service platform. Bull Am Meteorol Soc, 92, 325-342.

Kotharkar R, Bagade A, 2017: Local Climate Zone classification for Indian cities: A case study of Nagpur. Urban Clim, http://dx.doi.org/10.1016/j.uclim.2017.03.003

Kovács A, Unger J, Gál CV, Kántor N, 2016: Adjustment of the thermal component of two tourism climatological assessment tools using thermal perception and preference surveys from Hungary. Theor Appl Climatol, 125, 113-130.

Krayenhoff ES, Voogt JA, 2007: A microscale three-dimensional urban energy balance model for studying surface temperatures. Bound-Layer Meteorol 123, 433-461.

Kuchcik M, Błażejczyk K, Milewski P, Szmyd J 2014: Urban climate research in Warsaw: the results of microclimatic network measurements. Geographia Polonica, 87(4), 491-504. 
Kuik F, Lauer A, Churkina G, van der Gon, HAD, Fenner D, Mar KA, Butler TM, 2016: Air quality modelling in the Berlin-Brandenburg region using WRF-Chem v3. 7.1: sensitivity to resolution of model grid and input data. Geoscient Model Develop, 9(12), 4339-4363.

Kupiainen M Samuelsson P, Jones C, Jansson C, Willén U, Hansson U, Ullerstig A, Wang S, Döscher R, 2011: Rossby Centre regional atmospheric model, RCA4. http:/www.smhi.se/en/research/researchdepartments/climate-research-rossby-centre2-552/rossby-centre-regional-atmospheric-model-rca41.16562

Kusaka H, Kimura F, 2004: Coupling a singlelayer urban canopy model with a simple atmospheric model: impact on urban heat island simulation for an idealized case. J Meteorol Soc Japan, 82, 6780.

Kusaka H, Kondo H, Kikegawa Y, Kimura F, 2001: A simple single-layer urban canopy model for atmospheric models: comparison with multi-layer and slab models. Bound-Layer Meteor, 101, 329-358.

Le Moigne P, et al., 2012: "SURFEX scientific documentation." Note de centre (CNRM/GMME), MétéoFrance, Toulouse, France, $237 \mathrm{p}$.

Leconte F, Bouyer J, Claverie R, Pétrissans M, 2015: Using local climate zone scheme for UHI assessment: evaluation of the method using mobile measurements. Build Environ, 83, 39-49.

Lee S, Ha J, Cho H, 2017: Spatial and Temporal Effects of Built Environment on Urban Air Temperature in Seoul City, Korea: An Application of Spatial Regression Models. J Asian Architect Build Eng, 16(1), 123-130.

Lehnert M, Geletič J, Husák J, Vysoudil M, 2015: Urban field classification by "local climate zones" in a medium-sized Central European city: the case of Olomouc (Czech Republic). Theor Appl Climatol, 122, 531-541.

Lelovics E, Unger J, Gál T, Gál CV, 2014: Design of an urban monitoring network based on Local Climate Zone mapping and temperature pattern modelling. Climate Res, 60, 51-62.

Lemonsu A, Masson V, 2002: Simulation of a summer urban breeze over Paris. Bound-Layer Meteorol, 104(3), 463-490.

Lemonsu A, Grimmond CSB, Masson V, 2004: Modelling the surface energy balance of an old Mediterranean city core. J Appl Meteor, 43, 312-327.

Lin T-P, Matzarakis A, 2008: Tourism climate and thermal comfort in Sun Moon Lake, Taiwan. Int $\mathbf{J}$ Biometeorol, 52, 281-290.

Manabe S, 1969: Climate and the ocean circulation. 1: The atmospheric circulation and hydrology of the Earth's surface. Mon Wea Rev, 97, 739-774.

Maronga B, Gryschka M, Heinze R, Hoffmann F, Kanani-Sühring F, Keck M, Ketelsen K, Letzel MO, Sühring M, Raasch S, 2015: The Parallelized Large-Eddy Simulation Model (PALM) version 4.0 for atmospheric and oceanic flows: model formulation, recent developments, and future perspectives. Geosci Model Dev, 8, 2515-2551.

Martilli A, Clappier A, Rotach M, 2002: An urban surface exchange parameterization for mesoscale models. Bound-Layer Meteorol, 104, 261-304.

Masson V, 2000: A physically-based scheme for the urban energy budget in atmospheric models. BoundLayer Meteorol, 94, 357-397.

Masson V, Grimmond CSB, Oke TR, 2002: Evaluation of the Town Energy Balance (TEB) scheme with direct measurements from dry districts in two cities. J Appl Meteor, 41, 1011-1026.

Masson V, 2006: Urban surface modeling and the meso-scale impact of cities. Theor Appl Climatol, 84, 35-45.

Masson V, et al., 2013: The SURFEXv7. 2 land and ocean surface platform for coupled or offline simulation of earth surface variables and fluxes. Geosci Model Develop, 6, 929-960.

Matuschek O, Matzarakis A, 2010: Estimation of sky view factor in complex environment as a tool for applied climatological studies. Berichte des Meteorologischen Instituts der Albert-Ludwigs Universität Freiburg, 20, 534-539.

Matzarakis A, Matuschek O, 2010: Sky view factor as a parameter in applied climatology-rapid estimation by the SkyHelios model. Meteorol Z, 20, 39-45.

Matzarakis A, Mayer H, 1996: Another kind of environmental stress: thermal stress. WHO Newsletter, $18,7-10$.

Matzarakis A, Mayer H, Iziomon MG, 1999: Applications of a universal thermal index: physiological equivalent temperature. Int J Biometeorol, 43, 76-84.

Matzarakis $A$, Rutz F, Mayer H, 2007: Modelling radiation fluxes in simple and complex environments - application of the RayMan model. Int J Biometeorol, 51, 323-334.

Matzarakis A, Rutz F, Mayer H, 2010: Modelling radiation fluxes in simple and complex environments: basics of the RayMan model. Int J Biometeorol, 54, 131-139. 
May W, Roeckner E, 2001: A time-slice experiment with the ECHAM4 AGCM at high resolution: The impact of horizontal resolution on annual mean climate change. Clim Dyn, 17, 407-420.

Mayer H, 1993: Urban bioclimatology. Experientia, 49, 957-963.

Mayer H, Höppe P, 1987: Thermal comfort of man in different urban environments. Theor Appl Climatol, 38, 43-49

Mayer H, Matzarakis A, 1998: Human-biometeorological assessment of urban bioclimates' thermal component. Report of Research Center for Urban Safety an Security, Univ Kobe, Special Report, 1, 155168.

McPherson RA, Fiebrich C, Crawford KC, Elliott RL, Kilby JR, Grimsley DL, Martinez JE, Basara JB, Illston BG, Morris DA, Kloesel KA, Stadler SJ, Melvin AD, Sutherland AJ, Shrivastava H, 2007: Statewide monitoring of the mesoscale environment: a technical update on the Oklahoma Mesonet. J Atmos Ocean Tech, 24, 301-321.

Meier F, Fenner D, Grassmann T, Otto M, Scherer D, 2017: Crowdsourcing air temperature from citizen weather stations for urban climate research. Urban Clim, 19, 170-191.

Meinshausen M, Smith SJ, Calvin K, Daniel JS, Kainuma MLT, Lamarque J-F, Matsumoto K, Montzka SA, Raper SCB, Riahi K, Thomson A, Velders GJM, van Vuuren DPP, 2011: The RCP greenhouse gas concentrations and their extensions from 1765 to 2300. Climatic Change, 2011, 109, 213-241.

Mikami T, Ando H, Morishima W, Izumi T, Shioda T, 2003: A new urban heat island monitoring system in Tokyo. 5th Int. Conf. on Urban Climate, Lodz, Poland, O.3.5.

Mills $G$, 1993: Simulation of the energy budget of an urban canyon - I. Model structure and sensitivity Test. Atmos Environ, 27B, 157-170.

Mills G, 1997: An urban canopy-layer climate model. Theor Appl Climatol, 57, 229-244.

Mills G, Ching J, See L, Bechtel B, Foley M, 2015: An introduction to the WUDAPT project. In 9th International Conference on Urban Climate, Toulouse.

Milošević DD, Savić SM, Marković V, Arsenović D, Šećerov I, 2016: Outdoor human thermal comfort in local climate zones of Novi Sad (Serbia) during heat wave period. Hung Geogr Bull, 65, 129-137.

Moss, RH et al., 2008: Towards New Scenarios for Analysis of Emissions, Climate Change, Impacts, and Response Strategies (IPCCExpertMeeting Report, IPCC,Geneva, 2008)

Moss, RH et al., 2010: The next generation of scenarios for climate change research and assessment. Nature, 463, 747-756.

Möller F, 1954: Ein Kurzverfahren zur Bestimmung der langwelligen Ausstrahlung dicker Atmosphärenschichten. Arch Met Geophys Biokl, A7, 158-169.

Muller CL, Chapman L, Grimmond CSB, Young DT, Cai X, 2013: Sensors and the city: a review of urban meteorological networks. Int J Climatol, 33, 1585-1600.

Müller N, Kuttler W, Barlag A-B, 2014: Counteracting urban climate change: adaptation measures and their effect on thermal comfort. Theor Appl Climatol, 115, 243-257.

Nakamura Y, Oke TR, 1988: Wind, temperature and stability conditions in an east-west oriented urban canyon. Atmos Environ, 22, 2691-2700.

Nakicenovic N, Swart R, (eds.) 2000: Emissions Scenarios. A Special Report of IPCC Working Group III, Cambridge University Press, Cambridge, UK, 599p.

Nikolopoulou M, Baker N, Steemers K, 2001: Thermal comfort in outdoor urban spaces: Understanding the human parameter. Sol Energy 70, 227-235.

Noto K, 1996: Dependence of heat island phenomena on stable stratification and heat quantity in a calm environment. Atmos Envinron, 30, 475-485.

Offerle B, Grimmond CSB, Oke TR, 2003: Parameterization of net all-wave radiation for urban areas. J Appl Meteor, 42, 1157-1173.

Ohashi Y, Genchi Y, Kikegawa Y, Kondo H, Yoshikado H, Hirano Y, 2007: Influence of air-conditioning waste heat on air temperature in Tokyo office areas during summer: numerical experiments using an urban canopy model coupled with a building energy model. J Appl Meteorol Climatol, 46, 66-81.

Ohashi Y, Kikegawa Y, Ihara T, Sugiyama N, 2014: Numerical simulations of outdoor heat stress index and heat disorder risk in the 23 wards of Tokyo. J Appl Meteorol Climatol, 53, 583-597.

Oke TR, 1973: City size and the urban heat island. Atmos Environ, 7, 769-779.

Oke, TR, 1974: Review of urban climatology 1968-1973. WMO Tech. Note No. 134.

Oke TR, 1976: The distinction between canopy and boundary-layer urban heat islands. Atmosphere, 14, 268-277.

Oke TR, 1981: Canyon geometry and the nocturnal urban heat island: comparison of scale model and field obsevations. J Climatol, 1, 237-254.

Oke TR, 1982: The energetic basis of the urban heat island. Quart J Roy Meteorol Soc, 108, 1-24.

Oke TR, 1987: Boundary Layer Climates. Routledge, London-New-York, 405 p.

Oke TR, 1988: The urban energy balance. Progr Phys Geogr, 12, 471-508. 
Oke TR, 1998: An algorithmic scheme to estimate hourly heat island magnitude. In Preprints, 2nd Urban Environment Symposium, 2-6 November, Albuquerque, NM.

Oke TR, 2004: Initial guidance to obtain representative meteorological observations at urban sites. WMO/TD No. $1250,51 \mathrm{p}$.

Oke TR, 2006: Initial guidance to obtain representative meteorological observations at urban sites. Instruments and Observing Methods, Report No. 81, WMO/TD-No. 1250,

Oke TR, 2008: Urban observations. Guide to Meteorological Instruments and Methods of Observation. Part II, Observing Systems. 7th ed., WMO-No. 8, World Meteorological Organization, II-11-1-II-1125

Oke TR, Hannell FG, 1970: The form of the urban heat island in Hamilton, Canada. In Urban climates. WMO Tech. Note, 08, 113-126.

Oke TR, Maxwell GB, 1975: Urban heat island dinamics in Montreal and Vancouver. Atmos Environ, 9, 191-200.

Oleson KW, Bonan GB, Feddema JJ, Vertenstein M, Grimmond CSB, 2007: An urban parametrization for a global climate model. Part I: Formulation and Evaluation for two cities. J Appl Meteorol Climatol, 47, 1039-1059.

Palmer TN, et al., 2004: Development of a European multimodel ensemble system for seasonal-to-interannual prediction (DEMETER). Bull Am Meteorol Soc, 85(6), 853-872.

Park H-S, 1987: Variations in the urban heat island intensity affected by geographical environments. Environmental Research Center Papers, 11, The University of Tsukuba, Ibaraki, Japan, 79 p.

Péczely Gy, 1979: Éghajlattan. Tankönyvkiadó, Budapest.

Peterson JT és Stoffel TL, 1980: Analysis of urban-rural solar radioation from St. Louis, Missouri. J Appl Meteorol, 19, 275-283.

Petralli M, Massetti L, Orlandini S, 2011: Five years of thermal intra-urban monitoring in Florence (Italy) and application of climatological indices. Theor Appl Climatol, 104, 349-356.

Petralli M, Massetti L, Brandani G, Orlandini S, 2014: Urban planning indicators: useful tools to measure the effect of urbanization and vegetation on summer air temperatures. Int J Climatol, 34, 1236-1244.

Pickup J, de Dear R, 2000: An Outdoor Thermal Comfort Index (OUT_SET*) - Part I - The Model and its Assumptions. In de Dear R, Kalma J, Oke T, Auliciems A (eds): Biometeorology and Urban Climatology at the Turn of the Millenium. Selected Papers from the Conference ICB-ICUC'99 (Sydney, 8-12 Nov. 1999). WMO, Geneva, WCASP-50, 279-283.

Pieczka I, Szabóné André K, Pongrácz R, Bartholy J, 2017: Regionális klímamodell-szimulációk eredményei az új RCP-szcenáriók figyelembevételével. Légkör, 62, 175-178.

Piringer M, Grimmond CSB, Joffre SM, Mestayer P, Middleton DR, Rotach MW, Baklanov A, De Ridder K, Ferreira J, Guilloteau E, Karppinen A, Martilli A, Masson, V, Tombrou M, 2002: Investigating the surface energy balance in urban areas-recent advances and future needs. Water Air Soil Poll: Focus, 2(5-6), 1-16.

Pongrácz R, Bartholy J, Pieczka I, Szabóné André K, 2016: Estimation of regional climate in european and mediterranean subregions using different RCP scenarios. In Proceedings, 96th AMS Annual Meeting. New Orleans, Louisiana. Paper 631, 5 p.

Provencal S, Bergeron O, Leduc R, Barrette N, 2016: Thermal comfort in Quebec City, Canada: sensitivity analysis of the UTCI and other popular thermal comfort indices in a mid-latitude continental city. Int J Biometeorol, 60, 591-603.

Puliafito SE, Bochaca FR, Allende DG, Fernandez R, 2013: Green areas and microscale thermal comfort in arid environments: A case study in Mendoza, Argentina. Atmos Climat Sci, 3, 372-384.

Quanz JA, Ulrich S, Fenner D, Holtmann A, Eimermacher J, 2018: Micro-scale variability of air temperature within a local climate zone in Berlin, Germany, during summer. Climate, 6(1), 5.

Randall DA, Wood RA, Bony S, Colman R, Fichefet T, Fyfe J, Kattsov V, Pitman A, Shukla J, Srinivasan J, Stouffer RJ, Sumi A, Taylor KE, 2007: Climate Models and Their Evaluation. In: Climate Change 2007: The Physical Science Basis. Contribution of Working Group I to the Fourth Assessment Report of the Intergovernmental Panel on Climate Change. Cambridge University Press, Cambridge, UK and New York, NY, USA, 74 p.

Resler J, Krč P, Belda M, Juruš P, Benešová N, Lopata J, Vlček O, Damašková D, Eben K, Derbek P, Maronga B, Kanani-Sühring F, 2017: PALM-USM v1.0: a new urban surface model integrated into the PALM large-eddy simulation model. Geosci Model Dev, 10, 3635-3659.

Rogelj J, Meinshausen M, Knutti R, 2012: Global warming under old and new scenarios using IPCC climate sensitivity range estimates. Nature climate change, 2(4), 248-253.

Rundel PW, Graham EA, Allen MF, Fisher JC, Harmon TC, 2009: Environmental sensor networks in ecological research. New Phytologist 182, 589-607. 
Ruti PM., et al., 2016: Med-CORDEX initiative for Mediterranean climate studies. Bull Am Meteorol Soc, 97(7),1187-1208.

Salamanca F, Martilli A, 2010: A new building energy model coupled with an urban canopy parameterization for urban climate simulations-part II. Validation with one dimension offline simulations. Theor Appl Climatol, 99, 345-356.

Schär C, Vidale PL, Luthi D, Frei C, Häberli C, Liniger MA, Appenzeller C, 2004: The role of increasing temperature variability in European summer heatwaves. Nature, 427, 332-336.

Schatz J, Kucharik CL, 2014: Seasonality of the urban heat island effect in Madison, Wisconsin. J Appl Meteorol Climatol, 53, 2371-2386.

Schlünzen KH, Hinneburg D, Knoth O, Lambrecht M, Leitl B, López S, Lüpkes C, Panskus H, Renner E, Schatzmann M, Schoenemeyer T, Trepte S, Wolke R, 2003: Flow and transport in the obstacle layer: first results of the micro-scale model MITRAS. J Atmos Chem, 44, 113-130.

Schroeder AJ, Basara JB, Illston BG, 2010: Challangesassociated with classifying urban meteorological stations: The Oklahoma City Micronet example. Open Atmos Sci J, 4, 88-100.

Sharma A, Fernando HJ, Hamlet AF, Hellmann JJ, Barlage M, Chen F, 2017: Urban meteorological modeling using WRF: a sensitivity study. Int J Climatol, 37(4), 1885-1900.

Siebert J, Sievers $U$, Zdunkowski W, 1992: A one-dimensional simulation of the interaction between land surface processes and the atmosphere. Bound-Layer Meteorol, 59, 1-34.

Sievers U, 2012: Das kleinskalige Strömungsmodell MUKLIMO_3 Teil 1: Theoretische Grundlagen, PCBasisversion und Validierung, Berichte des Deutschen Wetterdienstes 240. Offenbach am Main, Germany, $136 \mathrm{p}$.

Sievers U, 2016: Das kleinskalige Strömungsmodell MUKLIMO_3. Teil 2: Thermodynamische Erweiterungen, Berichte des Deutschen Wetterdienstes 248. Offenbach am. Main, Germany $151 \mathrm{p}$.

Sievers $U$, Früh B, 2012: A practical approach to compute short-wave irradience interacting with subgridscal buildings. Meteorol Z, 21, 349-364.

Sievers $U$, Forkel R, Zdunkowski W, 1983: Transport equations for heat and moisture in the soil and their application to boundary layer problems. Beitr Physik Atmos, 56, 58-83.

Skamarock WC, Klemp JB, Dudhia J, Gill DO, Barker DM, Duda MG, Huang XY, Wang W, Powers JG, 2008: A Description of the Advanced Research WRF Version 3. NCAR Tech. Note NCAR/TN475+STR, $113 \mathrm{p}$.

Skarbit N, Gál T, Unger J, 2015: Airborne surface temperature differences of the different Local Climate Zones in the urban area of a medium sized city. In: Urban Remote Sensing Event (JURSE), 2015 Joint. IEEE, 1-4.

Skarbit N, Gál T, 2016: Projection of intra-urban modification of night-time climate indices during the 21 st century. Hung Geogr Bull, 65, 117-128.

Skarbit N, Stewart ID, Unger J, Gál T, 2017: Employing an urban meteorological network to monitor air temperature conditions in the 'local climate zones' of Szeged (Hungary). Int J Climatol, 37, 582-596.

Smoliak BV, Snyder PK, Twine TE, Mykleby PM, Hertel WF, 2015: Dense network observations of the twin cities canopy-layer urban heat island. J Appl Meteorol Climatol, 54, 1899-1917.

Souch C, Grimmond S, 2006: Applied climatology: urban climate. Prog Phys Geogr, 30, 270-279.

Staiger H, Laschewski G, Grätz A, 2012: The perceived temperature - a versatile index for the assessment of the human thermal environment. Part A: scientific basics. Int J Biometeorol, 56, 165-176.

Steadman $R G$, 1971: Indices of windchill of clothed persons. J Appl Meteorol, 10, 674-683.

Stewart ID, Oke TR, 2006: Methodological concerns surrounding the classification of urban and rural climate stations to define urban heat island magnitude. Prepints 6th International Conference on Urban Climate, Göteborg, Sweden, 431-434.

Stewart ID, Oke TR, 2009: Newly Developed "Thermal Climate Zones" for Defining and Measuring Urban Heat Island "Magnitude" in the Canopy Layer, Timothy R. Oke Symposium, Phoenix, AZ, 1115 Jan 2009. American Meteorological Society, Boston, MA.

Stewart ID, Oke TR, 2010: Thermal differentiation of Local Climate Zones using temperature observations from urban and rural field sites. Ninth Symposium on Urban Environment, Keystone, Colorado

Stewart ID, 2011: Redefining the Urban Heat Island. PhD dissertation, Department of Geography, University of British Columbia, Vancouver, Canada, $352 \mathrm{pp}$.

Stewart ID, Oke TR, 2012: Local climate zones for urban temperature studies. Bull Am Meteorol Soc, 93(12), 1879-1900.

Stewart ID, Oke TR, Krayenhoff ES, 2014: Evaluation of the 'local climate zone' scheme using temperature observations and model simulations. Int J Climatol, 34, 1062-1080.

Sundborg A, 1950: Local climatological studies of the temperature conditions in an urban area. Tellus, 2, 222-232. 
Sümeghy Z, Unger J, 2003: A települések hőmérséklet-módosító hatása - a szegedi hősziget-kutatások tükrében. Földrajzi közlemények, 127 (51), 23-44.

Taesler R, Anderson C, 1984: A method for solar radiation computings using routine meteorological observations. Energ Build, 7, 341-352.

Takács Á, Gál CV, Gulyás Á, Kiss M, Kántor N, 2017: Radiation conditions at a Central European square in a hot summer day, a case study from Szeged, Hungary. In 97th Annual Meeting of the American Meteorological Society.

Takane Y, Aoki S, Kikegawa Y, Yamakawa Y, Hara M, Kondo H, Iizuka S, 2015. Future projection of electricity demand and thermal comfort for August in Nagoya city by WRF-CM-BEM. J Environ Eng, 80, 973-983.

Takane Y, Kikegawa Y, Hara M, Ihara T, Ohashi Y, Adachi SA, Kondo H, Yamaguchi K, Kaneyasu N, 2017: A climatological validation of urban air temperature and electricity demand simulated by a regional climate model coupled with an urban canopy model and a building energy model in an Asian megacity. Int J Climatol, 37, 1035-1052.

Takebayashi H, Senoo M, 2017: Analysis of the relationship between urban size and heat island intensity using WRF model. Urban Clim, http://dx.doi.org/10.1016/j.uclim.2016.12.003

Thepvilojanapong N, Ono T, Tobe Y, 2010: A deployment of fine-grained sensor network and empirical analysis of urban temperature. Sensors, 10, 2217-2241.

Thom EC, 1959: The discomfort index. Weatherwise, 12, 57-60.

Thorsson S, Lindqvist M, Lindqvist S, 2004: Thermal bioclimatic conditions and patterns of behaviour in an urban park in Göteborg, Sweden. Int J Biometeorol, 48, 149-156.

Tokairin T, Kondo H, Yoshikado H, Genchi Y, Ihara T, Kikegawa Y, Hirano Y, Asahi K, 2006: Numerical study on the effect of buildings on temperature variation in urban and suburban areas in Tokyo. J Meteorol Soc Japan, 84, 921-937.

Toy S, Yilmaz S, 2010: Thermal sensation of people performing recreational activities in shadowy environment: a case study from Turkey. Theor Appl Climatol, 101, 329-340.

Unger J, 1997: Városklimatológia - Szeged városklímája. Acta Climatologica Universitatis Szegediensis, 31/B (Urban climate special issue) 69 p.

Unger J, Gál T, 2017: Városklíma: Szeged városklimatológiai vonatkozásai. GeoLitera, Szeged, 256 p.

Unger J, Makra L, 2007: Urban-rural difference in the heating demand as a consequence of the heat island. Acta Climatologica et Chorologica Universitatis Szegediensis, 40-41, 155-162.

Unger J, Sümeghy Z, 2002: Környezeti klimatológia. Kisléptékü éghajlatok, városklíma. JATEPress, Szeged, $202 \mathrm{p}$.

Unger J, Gál T, Rakonczai J, Mucsi L, Szatmári J, Tobak Z, van Leeuwen B, Fiala K, 2010: Modeling of the urban heat island pattern based on the relationship between surface and air temperatures. Időjárás, 114, 287-302.

Unger J, Savić S, Gál T, 2011: Modelling of the annual mean urban heat island pattern for planning of representative urban climate station network. Advances in Meteorology, 2011, ID 398613.

Unger J, Sümeghy Z, Kántor N, Gulyás Á, 2012: Kisléptékű környezeti klimatológia JATEPress, Szeged, 119-159.

Unger J, Lelovics E, Gál T, Mucsi L, 2014a: A városi hősziget fogalom finomítása a Lokális Klímazónák koncepciójának felhasználásával - példák Szegedről. Földrajzi Közlemények, 138, 50-63.

Unger J, Lelovics E, Gál T, 2014b: Local Climate Zone mapping using GIS methods in Szeged. Hung Geogr Bull, 63, 29-41.

Unger J, Savić S, Gál T, Milošević D, 2014c: Urban climate and monitoring network system in Central European cities. Novi Sad, $101 \mathrm{p}$.

Unger J, Gál T, Csépe Z, Lelovics E, Gulyás Á, 2015: Development, data processing and preliminary results of an urban human comfort monitoring and information system. Időjárás, 119, 337-354.

Unger J, Skarbit N, Gál T, 2017: Szegedi városklíma méröállomás-hálózat és információs rendszer. Légkör, 61, 114-118.

Unger J, Skarbit N, Gál T, 2018: Evaluation of outdoor human thermal sensation of local climate zones based on long-term database. Int J Biometeorol, 62(2), 183-193.

United Nations, 1980: Patterns of urban and rural population grow. https://esa.un.org/unpd/wup/Archive/ Files/studies/United\%20Nations\%20(1980)\%20-\%20Patterns\%20of\%20Urban\%20and\%20Rural\% 20Population\%20Growth.pdf

United Nations, 2015: World Urbanization Prospects. The 2014 Revisions. https://esa.un.org./unpd /wup /Publications/Files/WUP2014-Report.pdf

Upmanis H, Eliasson I, Lindquist S, 1998: The influence of green areas on nocturnal temperatures in a high latitude city (Göteborg, Sweden). Int J Climatol, 18, 681-700. 
URBAN-PATH Project, 2014: Evaluations and Public Display of Urban Patterns of Human Thermal Conditions. http://urban-path.hu/

Yaghoobian N, Kleissl J, 2012: An indoor-outdoor building energy simulator to study urban modification effects on building energy use - model description and validation. Energ Build, 54, 407-417.

Valko P, 1966: Die Himmelsstrahlung in ihrer Beziehung zu verschiedenen Parametern. Arch Meteorol Geophys Bioclimatol, B14, 337-359.

van der Linden P, Mitchell JE, 2009: ENSEMBLES: Climate change and its impacts-Summary of research and results from the ENSEMBLES project. $160 \mathrm{p}$.

van Hove LWA, Jacobs CMJ, Heusinkveld BG, Elbers JA, van Driel BL, Holtslag AAM, 2015: Temporal and spatial variability of urban heat island and thermal comfort within the Rotterdam agglomeration. Build Environ, 83, 91-103.

van Meijgaard E, van Ulft LH, Lenderink G, de Roode SR, Wipfler L, Boers R, Timmermans RMA, 2012: Refinement and application of a regional atmospheric model for climate scenario calculations of Western Europe. Climate changes Spatial Planning publication: KVR 054/12, ISBN/EAN 978-908815-046-3, $44 \mathrm{p}$.

van Vuuren DP, Edmonds J, Kainuma M, Riahi K, Thomson A, Hibbard K, Hurtt GC, Kram T, Krey V, Lamarque J-F, Masui T, Meinshausen M, Nakicenovic N, Smith SJ, Rose SK, 2011: The representative concentration pathways: an overview. Climatic Change, 109, 5-31.

$V D I, 1998$ : Methods for the human-biometeorological assessment of climate and air hygiene for urban and regional planning. Part I: Climate. VDI 3787, Part 2. Beuth, Berlin, 29 p.

Voldoire A, et al., 2013: The CNRM-CM5. 1 global climate model: description and basic evaluation. Clim Dynam, 40(9-10), 2091-2121.

Vu TC, Asaeda T, Ashie Y, 1999: Development of a numerical model for the evaluation of the urban thermal environment. J Wind Engineering, 81, 181-196.

Vu TC, Ashie Y, Asaeda T, 2002: A k- $\varepsilon$ turbulence closure model for the atmospheric boundary layer including urban canopy. Bound-Layer Meteor, 102, 459-490.

Wang R, Ren C, Xu Y, Lau K, Shi Y, 2017: Mapping the local climate zones of urban areas by GIS-based and WUDAPT methods: A case study of Hong Kong. Urban Climate, http://dx.doi.org/10.1016/j.uclim.2017.10.001

Warren EL, Young DT, Chapman L, Muller C, Grimmond CSB, Cai XM, 2016: The Birmingham Urban Climate Laboratory - A high density, urban meteorological dataset, from 2012-2014. Scientific Data, 3, paper 160038

Watkins R, Palmer J, Kolokotroni, M, Littlefair, P, 2010: The London Heat Island: results from summertime monitoring. Building Serv Eng Res Technol, 23(2), 97-106.

White JM, Eaton FD, August HD, 1978: The net radiation budget of the St. Louis Metropolitan Area. J Appl Met, 17, 593-599.

Wiebe EC, 2012: The Vancouver Island school-based weather network. Eighth Int. Conf. on Urban Climatology, ICUC-8, Dublin, Ireland.

World Meteorological Organization, 1983: Abridged final report, 8th session. Geneva, Comission for Climatology and Applications of Meteorology (WMO No. 600)

World Meteorological Organization, 2008: Guide to Meteorological Instruments and Methods of Observation, 7th edn. Instruments and Observing Methods Report (WMO No. 8)

Yamato H, Takahashi H, Mikami T, 2009: New urban heat island monitoring system in Tokyo metropolis. In Proceeding of the 7th International Conference on Urban Climate, June.

Zaninović K, Matzarakis A, 2009: The bioclimatological leaflet as a means conveying climatological information to tourists and the tourism industry. Int J Biometeorol, 53, 369-374.

Zdunkowski WG, Paegle J, Reilly J, 1975: The effects of soil moisture upon the atmospheric and soil temperature near the air-soil interface. Arch Met Geophys Biokl, A24, 245-268.

Žuvela-Aloise M, 2017: Enhancement of urban heat load through social inequalities on an example of a fictional city King's Landing. Int J Biometeorol, 61(3), 527-539.

Žuvela-Aloise M, Koch R, Neureiter A, Böhm R, Buchholz S, 2014: Reconstructing urban climate of Vienna based on historical maps dating to the early instrumental period. Urban Clim, 10, 490-508.

Žuvela-Aloise M, Koch R, Buchholz S, Früh B, 2016: Modelling the potential of green and blue infrastructure to reduce urban heat load in the city of Vienna. Climatic Change, 135(3-4), 425-438.

Zsebeházi G, Szépszó G, 2015: Investigating the urban climate characteristics of two Hungarian cities with SURFEX/TEB land surface model. Nineth Int. Conf. on Urban Climatology, ICUC-9, Toulouse, France. 


\section{Köszönetnyilvánítás}

Elsőként köszönettel tartozom témavezetőmnek, Dr. Unger Jánosnak, aki munkám során számos hasznos tanácsot és segítséget nyújtott, valamint a dolgozat megírásának folyamatát kritikusan és a legprecízebb módon kísérte végig.

Mellette külön köszönet illeti Dr. Gál Tamást, aki építő jellegü gondolataival és a téma iránti töretlen lelkesedésével nagyban elősegítette e munka elkészültét.

Köszönöm Dr. Iain D. Stewart-nak (University of Toronto) a tartalmas és tanulságos közös munkát. Továbbá köszönettel tartozom az SZTE Éghajlattani és Tájföldrajzi Tanszék valamennyi munkatársának és $\mathrm{PhD}$ hallgatójának támogatásukért és biztatásukért.

Köszönöm az Urban-Path projekt valamennyi résztvevőjének a szegedi méröállomáshálózat létrehozásáért és fenntartásért tett erőfeszítéseiket, amelyek nélkül dolgozatom nem készülhetett volna el. Emellett köszönetet szeretnék mondani az International Visegrad Fund, Standard Grant No. 2141022 csapatának a közös munkáért, ami nélkül értekezésem közel sem lett volna teljes. Külön köszönettel tartozom Hollósi Brigittának és Dr. Maja Žuvela-Aloise-nak (Zentralanstalt für Meteorologie und Geodynamik) a modellezés folyamatában felmerült kérdéseimben nyújtott segítségükért, valamint Dr. Anita Bokwa-nak (Uniwersytet Jagielloński w Krakowie) a projekt precíz vezetéséért.

Köszönöm a Deutscher Wetterdienst-nek, hogy használhattam az általuk megalkotott modellt vizsgálataimhoz. Köszönet illeti még az EURO-CORDEX munkatársait a 21. századi modelladatok előállításáért és nyílvánossá tételéért, valamint az Országos Meteorológiai Szolgálatot a szegedi állomáspár adatainak biztosításáért.

Külön köszönöm Dragan Milosevič-nek (Univerzitet u Novu Sadum) az angol nyelvi lektorálást.

Nem utolsósorban hálás vagyok családomnak és barátaimnak, hogy a munka legutolsó pillanatáig mellettem álltak és biztatásukkal nagymértékben hozzájárultak a dolgozat elkészüléséhez. 


\section{Summary}

Urban climate conditions of Szeged were analyzed using high spatial and temporal resolution measurement data and local scale climate model. The local climate zone (LCZ) system was applied, which is applicable worldwide, thus the results can be valid for other cities also. This system consists of 10 built-up and 7 land cover types. The name of zones are based on their different surface parameters, which are mostly the height and density of building or land cover (e.g. compact built-up and middle building height, briefly compact mid-rise).

At the installation of 24-element measurement station network in Szeged a crucial criterion was the representativeness of stations for their local climate zone. The network has outstanding spatial resolution internationally and provides thermal comparison between zones and within several LCZs. The temporal resolution of network is high also, since it measures air temperature and relative humidity in every minute. One-year data (01.06.2014-31.05.2015) was used for the evaluation of thermal properties of local climate zones. Three cases were distinguished: the whole period, days with ideal weather situation for urban heat island (UHI) genesis and a night of a chosen day, when the conditions were very appropriate for it. Inter- and intra-zone comparisons of air temperature were carried out, additionally the spatial and temporal dynamics of UHI were examined in detail.

The conception of local climate zones was based on the differences in air temperature. Nevertheless, the urban surplus does not reflect only in air temperature, but on the surface also, which can be quantified by remote sensing. Consequently the effects of zones on the surface temperature are worth to analyze. Surface- and air-based measurements from $12^{\text {th }}$ and $14^{\text {th }}$ August 2008 were used for the examination of surface temperature via LCZs. The human comfort conditions were analyzed also to determine the favorable and pleasant zones for outdoor activities annual and seasonal. In order to evaluate the thermal sensation of local climate zones the 10-minute averages of physiologically equivalent temperature (PET) were used for the longest period at the start of analysis (01.06.201431.01.2017). Additionally, the MUKLIMO_3 model and a dynamical-statistical method were applied to evaluate the changing of heat load in the $21^{\text {st }}$ century. Period 1981-2010 was used as reference, while the 21st century was presented through periods 2021-2050 and 2071-2100 based on EURO-CORDEX model data. Time period 1999-2010 was considered for the validation with the usage of rural and urban measurements.

In case of thermal differences among LCZs unequivocal tendency was noticeable in daily average and minimum temperatures and the values decreased from the compact and higher zones to the open and lower ones. Considering the daily maximum temperatures there was no clear tendency. The greatest differences among LCZs appear in summer minimum temperatures. On summer ideal days, when the thermal effect of the city prevailed, considerable alterations performed only at night.

The UHI intensity was examined via LCZs and the greatest values occurred in compact zones in summer, while the lowest temperatures appeared in the sparsely built zone (LCZ 9) in winter. On ideal days the differences among seasons were not as high as in the average annual case, moreover the warmest and coldest season altered according to LCZs. The alteration among the parts of day and seasons was the greatest in case of compact built-up, while the values of LCZ 9 depended on period at least.

Differences occurred also in case of examination of climate indices. Various tendencies were observed in warm indices, the number of days increased towards the compact zones, while this tendency was contrary in cold indices. In both case the greatest difference among zones appeared in minimum temperature based indices. 
The examination of intra-zone differences was possible in LCZ 5, 6 (open mid- and low-rise) and 9. On summer ideal days notable differences appeared only at night, which did not reach $1{ }^{\circ} \mathrm{C}$ in case of LCZ 5 and 9, but attained $1.5^{\circ} \mathrm{C}$ in LCZ 6. The greatest difference $\left(2{ }^{\circ} \mathrm{C}\right)$ in nocturnal UHI intensity among stations occurred in LCZ 6 on summer ideal days. These alterations due to the effect of microscale environment and prevailing NW wind direction and did not exceed inter-zone differences.

The maximal UHI intensity was at 2 hours after sunset in average annual conditions and it reached $2{ }^{\circ} \mathrm{C}$ in the city center. The magnitude was almost permanent in the rest of night. The remarkable decrease occurred at 10-11 hours after sunset and disappeared at the $12^{\text {th }}$ and $13^{\text {th }}$ hours. In ideal conditions the maximal intensity was much higher and developed later, it reached $3.5^{\circ} \mathrm{C}$ at 5 hours after sunset. In this case the decline also started at the $10^{\text {th }}$ hour, and the temperature differences in the $12^{\text {th }}$ and $13^{\text {th }}$ hours were negligible. The form of UHI by LCZs was examined at the night of one ideal day. Its intensity exceeded $5{ }^{\circ} \mathrm{C}$ in the compact zones and in the central part of LCZ 5 . The form of UHI stretched northwest direction in LCZ 8 (large low-rise), while in east and south, especially in the area of LCZ 6 and 9 the temperature differences were lower. In the western part of city in the area of LCZ 9 a cold advection resulted lower temperature values.

The most intensive cooling occurred at sunset and 1 hour after that, in case of ideal days. Consequently this period was crucial for the develop of UHI. This time the temperature gradient was below $-2,5^{\circ} \mathrm{C}$ in rural, and above $-2{ }^{\circ} \mathrm{C}$ in urban areas. In the following hours the values were around $0{ }^{\circ} \mathrm{C}$ and there was no noticeable change neither on the urban nor on the rural side. Remarkable differences appeared 10 hours after sunset, at the beginning of warming process. At that time the gradient in the city was below 0.5 , after $1-1,5^{\circ} \mathrm{C}$, while it was above in the rural area, respectively.

The differences among local climate zones in temperature gradient were largest at sunset, and sunrise, between of them they were minimal. The greatest absolute values appeared in the sparsely built and natural zones, while the lowest were in the compact ones. The occurring difference among local climate zones was $0.5^{\circ} \mathrm{C}$ in annual average, whereas on ideal days it exceeded $2{ }^{\circ} \mathrm{C}$. It approached $3{ }^{\circ} \mathrm{C}$ at the night of separately examined summer ideal day.

The observed sequence of local climate zones in the air temperature were determined in case of surface temperature also, which was the most remarkable if the buildings were neglected and only the surface was considered. Therefore the highest values were in the compact zones, which was followed by LCZ 5, the lowest were in LCZ 9. The values of LCZ 8 exceeded LCZ 6 due to the easier warm-up of flat roof buildings and higher rate of impervious surface. Beside the sequence of LCZs another statement was determined also, a typical surface temperature value was more frequent in the compact zones than in the sparsely built ones, thus their variability was lower.

Similarly the values of physiologically equivalent temperature decreased from compact to open zones independently of parts of day and seasons. Consequently, ideal zones for mitigate heat stress were LCZ 6 and 9. Appropriate zones for outdoor activities were LCZ 6 and 9 in the daytime and LCZ 2 and 3 (compact mid- and low-rise) in evening. "Cold" thermal sensation categories were more frequent in open, while "warm" categories in compact zones.

Considering the transitional seasons the period of favorable outdoor thermal conditions was longer in the built-up surfaces than in the natural ones. In spring in early afternoon, the pleasant thermal conditions started at the end of March, beginning of April depend on LCZs and finished at the end of May. In autumn it started at the beginning of season and ended in mid- or late October. In the evening, the ideal period for outdoor 
activities started at the middle of March in the built-up and three weeks later in the natural zones. In autumn the order was opposite, the natural zones from the end of September, the built-up zones from the beginning of October were not appropriate. In summer none of zones was suitable for outdoor activities in the afternoon, however at night all of them, especially the densely built were pleasant. In case of heat waves all of dwellers were exposed to remarkable heat stress for 6-8 hours in daytime.

Spatial distribution of heat load quantifying climate indices were examined applying local scale urban climate model. Remarkable differences occurred in the number of indices via LCZs in the present, the number of days was higher in the densely built-up zones. The values of every indices are likely to increase in the future both in the built-up and natural surfaces. This change slightly noticeable in the near future (2021-2050) and the difference between the optimistic and pessimistic scenarios is negligible. At the end of the 21 st century (2071-2100) the modification is notable according to RCP4.5, however its magnitude is much larger based on RCP8.5. The greatest changes appear in case of indices with stricter criterion, namely summer evenings and tropical nights. In these cases the magnitude of heat load is remarkable and can be connected to the development of heat waves, when the human body is exposed to huge heat load independently of climate zone.

Compared the result with measurements the model gives more accurate result in the urban area than in the natural surfaces. The most correct estimation is given for indices defined by minimum and maximum temperature. Accordingly, accurate result can be got in the city at the crucial period of urban climate examination, namely at night. In case of indices related to time, overestimation was detected, therefore the cooling after sunset was slower according to the model on both side.

The results showed in case of air and surface temperature as well as heat load the sequence of LCZs followed their number except LCZ 8, which overtook the value of LCZ 6. Consequently, in city planning the open and sparsely built-up zones are needed instead of compact buildings in order to decrease the heat load. This consideration becomes more necessary, since beside the urban surplus, the problem of global climate change should not be forgotten. The mitigation of heat load is essential because of increasing urban population also. The presented results can facilitate the work of city planners and decision makers to create livable cities, which are increasingly needed. 